\title{
Videoforskning på ulike
}

læringsarenaer:

Mangfoldig videodata i pedagogisk forskning og utvikling

Fredrik Rusk (red.)

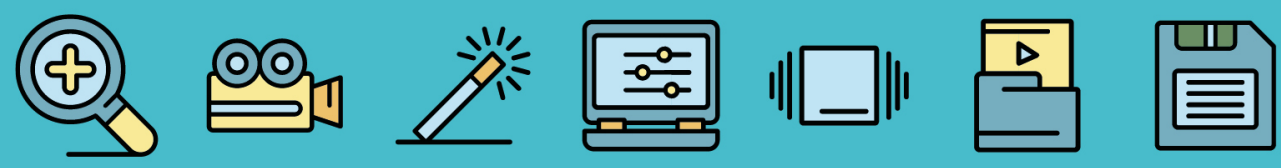

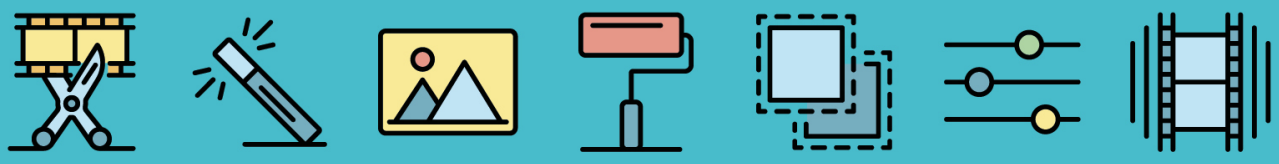

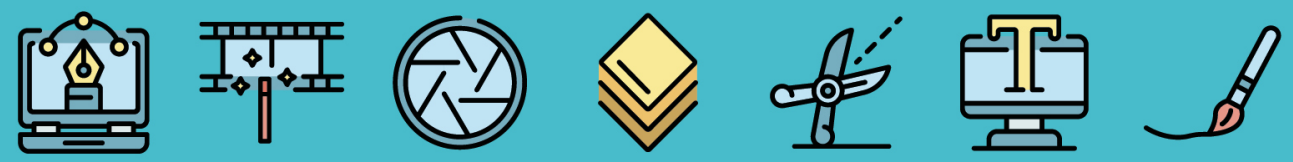

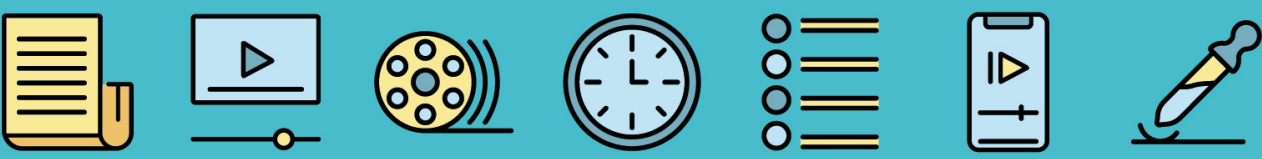

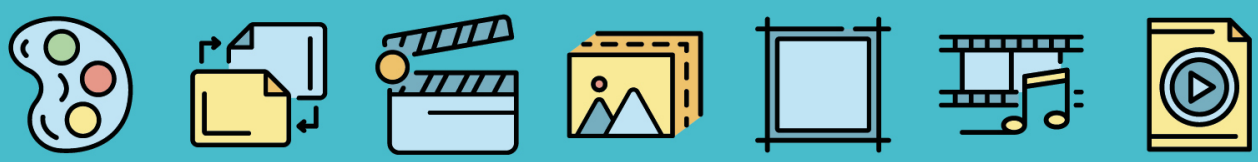

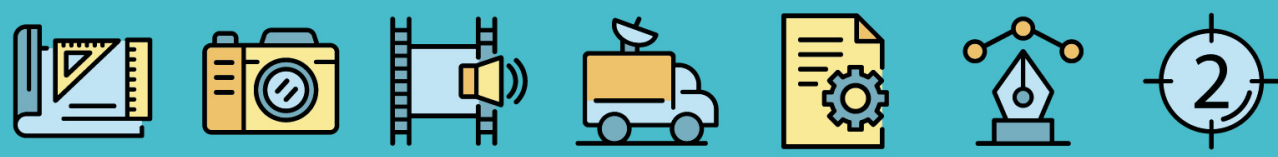




\section{Videoforskning på ulike læringsarenaer}



Fredrik Rusk (red.)

\section{Videoforskning på ulike læringsarenaer}

MANGFOLDIG VIDEODATA I PEDAGOGISK FORSKNING OG UTVIKLING 
(C) 2021 Ingvill Berg, Natallia Bahdanovich Hanssen, Marit Krogtoft, Julie Lysberg, Marie Nilsberth, Sandra Nystø Ráhka, Fredrik Rusk, Wenche Rønning, Matilda Ståhl, Trine Telnes, Cathrine Arntzen Tollåli og May Line Rotvik Tverbakk.

Dette verket omfattes av bestemmelsene i Lov om opphavsretten til åndsverk m.v. av 1961. Verket utgis Open Access under betingelsene i Creative Commons-lisensen CC BY-NC-ND 4.o. Denne lisensen lar andre kopiere, distribuere og spre verket $\mathrm{i}$ hvilket som helst medium eller format, under forutsetning av at det oppgis korrekt kreditering og lenke til lisens. Dette kan gjøres på enhver rimelig måte, men uten at det kan forstås slik at lisensgiver bifaller deg eller din bruk av verket. Materialet kan ikke benyttes til kommersielle formål. Dersom du remixer, bearbeider eller bygger på materialet, kan du ikke distribuere det endrede materialet.

Lisensvilkår: https://creativecommons.org/licenses/by-nc-nd/4.o/deed.no

ISBN trykt bok: 978-82-02-73042-o

ISBN PDF: 978-82-02-73041-3

ISBN EPUB: 978-82-02-75527-0

ISBN HTML: 978-82-02-75528-7

ISBN XML: 978-82-02-75529-4

DOI: https://doi.org/10.23865/noasp.153

Dette er en fagfellevurdert antologi.

Omslagsdesign: Cappelen Damm AS

Omslagsbilde: AdobeStock/ylivdesign

Cappelen Damm Akademisk / NOASP

noasp@cappelendamm.no 


\section{Innhold}

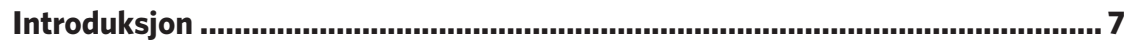

Fredrik Rusk

Del 1 Sentrale metodologiske problemstillinger rundt videoforskning .17

Kapittel 1 Metodiske og metodologiske vurderinger ved bruk av videoobservasjoner $\mathrm{i}$ forskning på læringskontekster 19 May Line Rotvik Tverbakk

Kapittel 2 Etiske aspekter ved videoforskning i et lite miljø 37 Sandra Nystø Ráhka

Kapittel 3 Visuelle vendinger i videoanalyse: Transkripsjon i møte med barnehagens marginaliserte og målbundne materialiteter. 55

Trine Telnes

Del 2 Fleksibilitet og mangfold i videoforskning på ulike læringsarenaer

Kapittel 4 Video-stimulated recall som datainnsamlingsmetode 81 Julie Lysberg

Kapittel 5 Why so toxic? Spelarjargong och stötande språkbruk skärminspelningar av e-sport i en pedagogisk kontext 101 Matilda Ståhl

Kapittel 6 Det store i det lille: Detaljert videoanalyse av gruppearbeid ...... 123 Ingvill Berg og Fredrik Rusk

Del 3 Video som ressurs for utvikling av profesjonell kunnskap og praksis 143

Kapittel 7 Video som endringsverktøy ipedagogisk utviklingsarbeid .145 Wenche Rønning 
Kapittel 8 Videoobservasjoner og videobaserte samtaler som metoder for kvalitetsutvikling av barnehageansattes spesialpedagogiske praksis. 165

Natallia B. Hanssen \& Marit Krogtoft

Kapittel 9 Klasseromsinteraksjon gjennom kameralinsen:

En videobasert studie av lærers relasjons- og

emosjonsarbeid $\mathbf{i}$ klasserommet 183

Cathrine Arntzen Tollåli, Fredrik Rusk og Marie Nilsberth

Om forfatterne 205 


\section{Introduksjon}

\section{Fredrik Rusk}

Fakultet for lærerutdanning og kunst- og kulturfag, Nord universitet, Bodø Fakulteten för pedagogik och välfärdsstudier, Åbo Akademi, Vasa, Finland

Research project after research project fail to include filming and insist on continuing the hopelessly inadequate note-taking of an earlier age, while the behaviour that film could have caught and preserved for centuries [...] disappears - disappears right in front of everybody's eyes. Why? What has gone wrong? (Mead, 1974, s. 4-5, i Heath et al., 2010, s. 2)

Sitatet ovenfor viser til målet med denne boka, som egentlig er ganske enkelt - samtidig som det, når man begynner å nøste i det, blir veldig komplekst. Bruk av video for forsknings- og utviklingsarbeid i og om interaksjonell praksis på forskjellige læringsarenaer er noe som kanskje burde være selvsagt i dagens samfunn, med alle muligheter vi har for å gjøre opptak av interaksjon. Det er det imidlertid ikke, noe som viser kompleksiteten i denne saken. For mange er det vanskelig å kunne forutse og tenke seg til hvordan de kan, eller skal, bruke video, selv om de er interesserte i å bedre forstå og/eller utvikle sosial praksis og læring i interaksjon på ulike arenaer. Faktorene som kompliserer den enkle handlingen å «bare» gjøre opptak er for eksempel: personvern (Jordan \& Henderson, 1995), etiske spørsmål (Aarsand \& Forsberg, 2010), teknisk kompetanse, observatørens paradoks (fenomenet som observeres påvirkes ubevisst av tilstedeværelsen av observatøren) og ikke minst det enkle spørsmålet om hva man skal inkludere på opptaket. Den primære situasjonen for å studere sosial interaksjon, språk, kognisjon og læring, er 
når flere deltakere utfører aktiviteter sammen (Goodwin, 200o). For å bedre forstå ovennevnte temaer må vi studere og forstå den faktiske sosiale interaksjonen. For tiden er der ikke andre datainnsamlingsmetoder som kan gi oss like reliable og valide data på sosial interaksjon som det vi kan få ved bruk av video.

I denne boka ønsker vi å vise hvor rik videoforskning innen pedagogiske kontekster kan være, og hvordan video også kan brukes for utviklingsarbeid der forskere samhandler med lærere og studenter. Målgruppen for denne boka er derfor primært andre forskere, men også andre som er på vei inn i forskningsaktivitet, eksempelvis masterstudenter eller ph.d.-kandidater. Videoforskning er i dag ikke begrenset til ett eller flere kamera som gjør opptak av aktivitet mellom lærer og elever, eller mellom elever i klasserom. Videoforskning er heller ikke det at du må ha et helt studio og utstyr i klasserom som ved filmproduksjon. Det er så mye rikere enn det. I denne boka har vi samlet en spennende samling forfattere, med rike og unike data fra ulike hold; metodisk, metodologisk og teoretisk. Søkelyset settes på fleksibiliteten og mangfoldet i bruk av video, og hvordan det at man bruker video som metode i seg selv ikke sier så mye om hva slags forskning eller utviklingsarbeid man driver med. Video er «bare» ett verktøy blant mange, men det kan brukes til flere ulike problemstillinger og på flere ulike måter. Det er dette som gjør det komplekst, men uten kompleksiteten ville det heller ikke vært så fleksibelt. Dette aspektet er det som gjør at du ikke trenger et stort videolaboratorium med dyrt utstyr for å filme god videodata til forsknings- og utviklingsarbeid. Du kan klare deg med et kamera, en mikrofon og en god plan og forståelse for hva du kan, og ikke kan, fange opp i ditt prosjekt.

Boka setter søkelys på overordnede kvalitative former for bruk av video på forskjellige læringsarenaer, og presenterer fleksibiliteten i bruk av video gjennom å problematisere video som metode gjennom egne forsknings- og utviklingsprosjekter. Med andre ord bruker vi ikke stor plass på å skrive om klassisk videoforskning i seg selv. Det har mange andre forfattere gjort på en veldig god måte (se f.eks. Blikstad-Balas, 2016; Derry et al., 2010; Goldman et al., 2007; Janik \& Seidel, 2009; Rusk et al., 2014; Sahlström, 2008). I stedet legger vi vekt på hvor fleksibel, brukbar 
og kreativ datainnsamling ved hjelp av video kan være, og hvor rikt datamateriale man kan skaffe seg. En annen ting som skiller boka fra annen litteratur på feltet, er tverrfagligheten som presenteres, men som uansett har to fellesnevnere som henger sammen. Det vil si, (1) bruk av video på forskjellige læringsarenaer for å samle inn data til forsknings- og utviklingsarbeid i (2) kombinasjon med intervju og/eller andre etnografiske metoder for å forstå en eller annen form for sosial praksis som kan kobles til læring som sosialt fenomen.

I en velkjent artikkel om læring, undervisning og klasseromsorganisasjon skriver klasseromsforskeren Nuthall (2005) at undervisning i klasserom er strukturert av ritualiserte rutiner, støttet av allment aksepterte myter om læring som er tilegnede gjennom våre egne opplevelser som studenter i klasserommet. Han fortsetter med å si at disse ritualiserte rutinene og mytene opprettholdes ikke bare av alles felles erfaring med skolegang, men også av lærerutdanningspraksisen, av måtene man vurderer læreres klasseromspraksis og av utdanningsforskningen. I artikkelen fremsetter Nuthall (2005) et overbevisende argument om viktigheten av å studere lokalt, detaljert og spesifikt. Han poengterer også mangelen på slike studier. Nuthall (2005, min oversettelse) sier: «Etter min mening ligger sannheten i detaljene» (s. 926); «Jeg hadde vært blind for betydningen av å forstå det spesifikke» (s. 905). Nå lurer vel leseren på hvorfor jeg beskriver dette. Jo, for hvis vi benytter Nuthalls argumenter på alle læringsarenaer, så betyr det at vi må finne måter å stå utenfor de ritualiserte rutinene og mytene på for å identifisere hvordan de styrer hva vi oppfatter, tror på og gjør, på de ulike læringsarenaene. Uten en slik tilnærming, vil vi ikke kunne reformere vår undervisning (se også Webster-Wright, 2009). Video kan bidra til å få dette til, men ikke alene. Uansett, hvis flere som er interesserte i forskning og utvikling om og av sosial praksis brukte video, kunne vi kanskje komme bort fra å anta hva som skjedde og hva noen egentlig sa, og i stedet studere videodata som kan hjelpe oss til å komme noe nærmere de faktiske situasjonene.

Vi må få en mer deskriptiv og strukturert forståelse av hvordan sosialisering, læring og undervisning foregår på ulike læringsarenaer. En måte å redusere kompleksiteten i den sosiale praksisen, og få en bedre sjanse til å forstå den og hvordan den er strukturert, er å bruke videodata (som 
man kan se på igjen og igjen og igjen), og slik analysere det vi faktisk kan observere ved å studere videodata på et nøyaktig nivå. På den måten havner vi ikke i «gjetnings-grøfta» og må spekulere på hva deltakerne kanskje tenker eller mener, men kan i stedet holde oss på et nivå der vi kan begrunne våre observasjoner i datamaterialet; det vi ser og hører. På den måten kan vi redusere en del av kompleksiteten, og samtidig få med oss hvordan interaksjonen skaper muligheter og begrensninger - for eksempel for læring.

Videodata i seg selv kan ikke bevise kognitiv aktivitet eller læring, men samtidig er det relativt generelt vedtatt at læring er et sosialt og interaktivt fenomen. Læring plasseres dermed i sosiale situasjoner og sammenhenger når individer, interaksjonsdeltakere, engasjerer seg i sosiale handlinger (Lave, 1993; Lave \& Wenger, 1991). Med andre ord ser man en sammenheng mellom læring, sosialisering og deltakelse i interaksjon. Fra et slikt perspektiv blir endringer i deltakelse i samspillet sett på som læring, i stedet for å se det som et uttrykk for en forestilt læring som finner sted i for eksempel individets mentale verden. Følgelig er læring og kontekster der læring skjer og gjøres, noe konkret som kan observeres og analyseres i det sosiale samspillet. Det er ikke bare noe som skjer i individets hode (Melander \& Sahlström, 2010; Seedhouse \& Walsh, 2010). Dette er noe som, for tiden, best kan fanges på video for å analysere det. Video kan hjelpe forsker og praktiker å se det store i det lille og se det lille i det store; se detaljene og det spesifikke, samtidig som man kan få en bedre forståelse for strukturer bak detaljene. Et av de overordnete argumentene i denne boka er det samme som Nuthall (2005) driver; du må først forstå praksis, før du kan endre og utvikle den, ellers kan du vanskelig få en forståelse av hva som vil skje når du endrer den.

Ifølge Meads sitat innledningsvis, kan en mer utbredt og kompetent bruk av video i forskning og utvikling på forskjellige læringsarenaer bidra til å forstå sosial praksis bedre. Men selv om video fanger opp mye, vil det uansett nettopp «redusere» interaksjonen og bare (gjen)gi en del av den faktiske sosiale interaksjonen der og da (se f.eks. Dalland et al., 2019; Heikkilä \& Sahlström, 2003; Mondada, 2012; Rusk et al., 2014). Men for tiden er video det beste redskapet vi har for å fange sosial praksis for senere analyse. 
Boka er organisert i ni kapitler inndelt i tre forskjellige seksjoner. En kort beskrivelse av hvert av kapitlene følger nedenfor.

\section{Del 1 Sentrale metodologiske problemstillinger rundt videoforskning}

\section{Metodologiske vurderinger ved bruk av videoobservasjoner i forskning på læringskontekster}

Kapittel 1 problematiserer metodologiske vurderinger ved bruk av video i forskning på læringskontekster med søkelys på områder som berører utvalg, teknologi, etikk og analyse. Bruk av videoobservasjoner gir muligheter for mer presise og nøyaktige bilder av hva som skjer i læringskontekstene enn hva man kan få ved bare å observere med det blotte øye. Samtidig kan det reises spørsmål ved om forskerens valg av fokus er mer rettet mot forskerens egne interesser enn mot situasjonen slik den virkelig er.

\section{Etiske aspekter ved videoforskning i et lite miljø}

Kapittel 2 setter søkelyset på etiske problemstillinger som fremkommer under feltarbeidet når du skal gjennomføre selve forskningen. Inngangen er et forskningsprosjekt der video ble brukt for å utvikle kunnskap om undervisningspraksis i samiskopplæringen. Det smale feltet og det lille miljøet gjorde etiske problemstillinger spesielt aktuelle, og det måtte tas særlige hensyn i forhold til både rekruttering, anonymisering og avklaring av egen forskerrolle. Kapittelet trekker også gjennomgående frem sentrale aspekter ved urfolksmetodologien som kan føre til mer etisk forsvarlig forskningpraksis, uansett hvilket felt det forskes innenfor.

\section{Visuelle vendinger i videoanalyse: Transkripsjon i møte med barnehagens marginaliserte og målbundne materialiteter}

Kapittel 3 utforsker hvordan videoforskeren kan bringe de rike audiovisuelle dataene inn i akademiske tekster gjennom å problematisere 
hvordan man kan transkribere og analysere tilstedeværelsen og praksisene til barnehagens yngste barn på en måte som viser deres agentskap og bidrag. En visuell vending mot poetisk videotranskripsjon, multimodal transkripsjon og en hybrid mellom tegninger og transkripsjon kan til dels gjøre kroppslige, romlige og materielle ressurser synlige. En fusjon mellom ord og bilder kan produsere nye former for kunnskap og bidra til transparens.

\section{Del 2 Fleksibilitet og mangfold i videoforskning på ulike læringsarenaer \\ Video-stimulated recall som datainnsamlingsmetode}

Kapittel 4 presenterer og diskuterer datainnsamlingsmetoden videostimulated recall (VSR), som er en avansert intervjuteknikk basert på videoobservasjon med påfølgende intervju. Valgte sekvenser fra den opprinnelige situasjonen brukes til å støtte informantens tilbakekalling av tanker i og refleksjon over situasjonen. Gjennom å presentere datainnsamlingsprosessen detaljert slik den ble utført i ett prosjekt, rettes søkelyset på muligheter og hvilke typer data metoden gir tilgang til, samtidig som metodiske vurderinger knyttet til metodens bruk problematiseres.

\section{Why so toxic? Spelarjargong och stötande språkbruk - skärminspelningar av e-sport i en pedagogisk kontext}

Formålet med kapittel 5 er todelt: (a) å analysere og diskutere spillersjargong i e-sport i en pedagogisk kontekst, og (b) å diskutere hvordan videoforskning gjennom skjermopptak muliggjør analyse av spillersjargong $i$ et nytt pedagogisk forskningsområde. Skjermopptakene, som er utført av deltakerne selv, inkluderer lagets interne voice chat, og gir et intimt deltakerperspektiv på spillerdiskurser i online spillkultur. Dette er et rom ingen utenforstående har tilgang til, ettersom den interne voice chat-en bare inkluderer inviterte spillere. Med andre ord får forskeren tilgang til intim og muligens sensitiv data. Kapittelet problematiserer det å få 
tilgang og samle slik data, samtidig som det fra et forskningsperspektiv er ekstremt verdifull data. Kapittelet tilbyr noen perspektiver og pekepinner om faktorer som må reflekteres over i fremtidige pedagogiske videoforskningsprosjekter om digital interaksjon. Gjennom å få bedre kunnskap om hvordan spillmiljøene faktisk er organisert, i stedet for å la oss styre av normative innspill og perspektiver, kan vi lære oss mer om hvordan vi kan skape mer inkluderende spillkontekster.

\section{Det store i det lille: Detaljert videoanalyse av gruppearbeid}

Hensikten med kapittel 6 er å diskutere bruken av videodata for å deskriptivt analysere på et detaljert nivå hvordan grupper, gjennom sosial interaksjon, deler ressurser og kunnskap med hverandre og hva det kan ha å si for hvordan man studerer og oppfatter læring i en videostudie. Video gir oss muligheten til å studere interaksjon på et detaljert nivå og se på situasjoner gjentatte ganger for blant annet å undersøke hvordan elever viser frem det de kan for hverandre, og hvordan de forhandler om kunnskap når de jobber sammen med praktiske oppgaver i grupper. Formålet er å vise at det er en merverdi i å gå inn på dette nivået av mikroanalyse i studier av læring. Studier som benytter seg av detaljert videoanalyse og studerer interaksjonen mellom elever i gruppearbeid gir viktig kunnskap og kompetanse som vi kan bruke i planlegging og gjennomføring av undervisning.

\section{Del 3 Video som ressurs for utvikling av profesjonell kunnskap og praksis}

\section{Video som endringsverktøy i pedagogisk utviklingsarbeid}

Kapittel 7 handler om bruk av video for å støtte lærernes profesjonelle læring. Kapittelet bruker en case for å utforske bruken av video i en lesson study-inspirert tilnærming. Konteksten er en prosess der lærere og forskere samarbeider om å revidere en eksisterende innholdsmodul i 
matematikk. Kapittelet diskuterer hvordan man kan få til grundig refleksjon om sentrale elementer i undervisningen gjennom å se på videoutdrag av undervisningen. Prosessen resulterer i en betydelig revisjon av modulen, samt gode muligheter for lærernes autentiske profesjonelle læring. Spørsmålene som er sentrale i kapittelet er: Hvordan reflekterer lærere over egen praksis når de blir utfordret gjennom videoobservasjoner fra denne, og hvilke endringer fører det til? Hva lærer lærerne, potensielt sett, gjennom slike prosesser?

\section{Videoobservasjoner og videobaserte samtaler som metoder for kvalitetsutvikling av barnehageansattes spesialpedagogiske praksis}

Kapittel 8 diskuterer hvordan videoobservasjoner og samtaler om videoobservasjoner kan bidra til å øke barnehageansattes bevissthet over egen pedagogisk praksis, og trene opp det profesjonelle blikket. På bakgrunn av resultatene som presenteres i kapittelet kan man si at dersom barnehageansatte skal ha muligheter til å studere seg selv og utvikle egen praksis, er det profesjonelle blikket noe som bør utvikles. I den sammenhengen er videoobservasjon og videobaserte samtaler uvurderlige hjelpemidler for å få nye perspektiver på - og å kunne utfordre - egen praksis.

\section{Klasseromsinteraksjon gjennom kameralinsen: En videobasert studie av lærers relasjons- og emosjonsarbeid i klasserommet}

Kapittel 9 viser hvordan videobaserte og deskriptive studier av klasseromsinteraksjon kan belyse relasjonelle og emosjonelle aspekter ved lærernes profesjonelle praksis, og hjelpe lærere å utvikle interaksjonell kompetanse som kan resultere i mer engasjerte og dynamiske klasserom. Basert på en samtaleanalytisk og videobasert studie av plenumundervisning, presenterer kapittelet hvordan lærere i klasserommet balanserer kontroll og progresjon i læringsaktiviteter med relasjonelle hensyn. Ved bruk av video beskrives ansiktsuttrykk, kroppslig orientering og blikk. 
Lærernes relasjons- og emosjonsarbeid gjøres i høy grad ikke-verbalt gjennom for eksempel øyeblikk med delt oppmerksomhet på en spesifikk ytring, eller gjennom gjensidig smil og latter. Relasjons- og emosjonsarbeid trenger ikke å være så komplisert. Det kan være små øyeblikk, men de kan ha stor betydning for utviklingen av deltakernes samtaler og emosjonelle holdninger.

\section{Referanser}

Aarsand, P. \& Forsberg, L. (2010). Producing children's corporeal privacy:

Ethnographic video recording as material-discursive practice. Qualitative Research, 10(2), 249-268.

Blikstad-Balas, M. (2016). Key challenges of using video when investigating social practices in education: Contextualization, magnification, and representation. International Journal of Research \& Method in Education, 40(5), 511-523. https://doi.org/10.1080/1743727X.2016.1181162

Dalland, C. P., Klette, K. \& Svenkerud, S. (2019). Video studies and the challenge of selecting time scales. International Journal of Research \& Method in Education, 43(1), 53-66. https://doi.org/10.1080/1743727X.2018.1563062

Derry, S. J., Pea, R. D., Barron, B., Engle, R. A., Erickson, F., Goldman, R., Hall, R., Koschmann, T., Lemke, J. L., Sherin, M. G. \& Sherin, B. L. (2010). Conducting video research in the learning sciences: Guidance on selection, analysis, technology, and ethics. The Journal of the Learning Sciences, 19(1), 3-53. https://doi.org/10.108o/10508400903452884

Goldman, R., Pea, R. E., Barron, B. \& Derry, S. J. (Red.). (2007). Video research in the learning sciences. Routledge.

Goodwin, C. (2000). Action and embodiment within situated human interaction. Journal of Pragmatics, 32(10), 1489-1522. https://doi.org/10.1016/So378-2166(99) ooog6-X

Heath, C., Hindmarsh, J. \& Luff, P. (2010). Video in qualitative research: Analysing social interaction in everyday life. Sage.

Heikkilä, M. \& Sahlström, F. (2003). Om användning av videoinspelning i fältarbete. Pedagogisk forskning i Sverige, 8(1-2), 24-41.

Janik, T. \& Seidel, T. (2009). The power of video studies in investigating teaching and learning in the classroom. Waxmann Publishing.

Jordan, B. \& Henderson, A. (1995). Interaction analysis: Foundations and practice. Journal of the Learning Sciences, 4, 39-103.

Lave, J. (1993). The practice of learning. I S. Chaiklin \& J. Lave (Red.), Understanding practice: Perspectives on activity and context (s.3-32). Cambridge University Press. 
Lave, J. \& Wenger, E. (1991). Situated learning. Cambridge University Press.

Melander, H. \& Sahlström, F. (2010). Lärande i interaktion. Liber.

Mondada, L. (2012). The conversation analytic approach to data collection.

I J. Sidnell \& T. Stivers (Red.), The handbook of conversation analysis (s. 32-56). Wiley-Blackwell.

Nuthall, G. (2005). The cultural myths and realities of classroom teaching and learning: A personal journey. The Teachers College Record, 107(5), 895-934.

Rusk, F., Pörn, M., Sahlström, F. \& Slotte-Lüttge, A. (2014). Perspectives on using video recordings in conversation analytical studies on learning in interaction. International Journal of Research \& Method in Education, 38(1), 39-55.

Sahlström, F. (2008). Från lärare till elever, från undervisning till lärande. Vetenskapsrådet.

Seedhouse, P. \& Walsh, S. (2010). Learning a second language through classroom interaction. I P. Seedhouse, S. Walsh \& C. Jenks (Red.), Conceptualising 'learning' in applied linguistics (s. 127-146). Palgrave Macmillan.

Webster-Wright, A. (2009). Reframing professional development through understanding authentic professional learning. Review of Educational Research, 79(2), 702-739. https://doi.org/10.3102/0034654308330970 
Del 1

Sentrale metodologiske problemstillinger rundt videoforskning 



\title{
KAPITTEL 1
}

\section{Metodiske og metodologiske vurderinger ved bruk av videoobservasjoner i forskning på læringskontekster}

\section{May Line Rotvik Tverbakk}

\section{Nord universitet}

\begin{abstract}
This chapter discusses methodological assessments using video in research on learning contexts. Depending on the purpose of the research, the use of video observations can provide opportunities for more precise and accurate images of what is happening in the learning contexts than what one can get by simply observing with the naked eye. Video observations can provide access to important information regarding the actions of individual actors and can also contribute to the exploration of more complex forms of interaction in teaching, both verbal and non-verbal. Accurate video observations enable access to details in interaction that the actors are not necessarily aware of in the social context. Video observations, technically speaking, can be regarded as very reliable, because the observations can be analyzed independently by the researcher responsible for the data collection. At the same time, it may be relevant to raise questions about whether the researcher's choice of focus is more aimed at the researcher's interests, rather than the situation as it is experienced. The purpose of this chapter is to discuss methodological issues related to the use of video observations in research.
\end{abstract}

Keywords: video observations, learning contexts, method, methodology, interaction

Sitering: Tverbakk, M. L. R. (2021). Metodiske og metodologiske vurderinger ved bruk av videoobservasjoner i forskning på læringskontekster. I F. Rusk (Red.), Videoforskning på ulike laringsarenaer: Mangfoldig videodata i pedagogisk forskning og utvikling (Kap. 1, s. 19-36). Cappelen Damm Akademisk. https://doi.org/10.23865/noasp.153.ch1

Lisens: CC BY-NC-ND 4.0 


\section{Innledning}

Videoobservasjoner benyttes på flere og ulike måter i læringskontekster (Seidel \& Thiel, 2017; Yousef et al., 2014). Med læringskontekster menes, i denne sammenhengen, bruk av videoobservasjoner i forskning på sosiale praksiser som på ulike måter involverer undervisning og læring. Kapitlet omhandler bruk av video i utforsking av ulike typer læringsarbeid der hovedhensikten er å utvikle kunnskap for «allmennheten» om bestemte pedagogiske fagfelt eller kompetanseområder hos læreren (Gaudin \& Chaliés, 2015; Hatlevik \& Egeberg, 2014; Tverbakk 2018; Valle, 2014). Videoobservasjoner er på denne måten også ofte benyttet i studier som for eksempel rettes mot sider ved samhandling og interaksjon mellom pedagog og barn/elever i læringskontekster (Baustad \& Bjørnestad, 2020; Klette et al., 2017; Rusk \& Pörn, 2019; Rusk \& Rønning, 2020).

Videobaserte studier benyttes innenfor ulike felt og disipliner (Tuma et al., 2014), og det er flere grunner til at video i økende grad tas i bruk i forskning innenfor læringskontekster. Disse kontekstene er ofte komplekse, fordi undervisnings- og læringssituasjoner ofte består av ulike aktiviteter og samhandlingsformer samtidig. I denne «samtidigheten» kan det ligge forskningsmessig interessante samhandlingsmønstre som kan bidra til å utvikle vår forståelse både av og om læring og undervisning som vanskelig lar seg fange opp utelukkende ved for eksempel bruk av feltnotater eller lydopptak (Blikstad-Balas, 2017). Videostudier som er godt designet, kan dermed være velegnet for å bringe inn ny kunnskap om ulike samhandlingsmønstre - som de vi kan finne i undervisningsog læringssituasjoner.

Selv om det ikke nødvendigvis kreves avansert utstyr for å kunne fange interessante øyeblikk i forskningssammenheng, står forskeren overfor en rekke metodiske og metodologiske valg som har betydning for kvaliteten på datamaterialet. I dette kapitlet belyses for det første noen av aspektene ved video som metodisk verktøy, før vi går nærmere inn på sider ved verktøyet som kan synes å være viktig for å forstå kontekstene. Aspektene er knyttet til utvalg, teknologi, etikk og analyse; områder som kan sees på som sentrale, uavhengig av fagområde eller metodisk orientering (Derry et al., 2010). For det andre tar kapitlet for seg ulike 
metodologiske interaksjoner som kan fungere som mulige tilganger for forskeren i analyse av videodatamateriale innenfor læringskontekster (Järvinen \& Mik-Meyer, 2005). Kapitlet drøfter avslutningsvis noen sentrale implikasjoner som de metodiske og metodologiske aspektene har for forskerrollen.

\section{Videoobservasjoner av læringskontekster, noen metodiske og metodologiske perspektiver}

\section{Video som metodisk verktøy for forskning på læringskontekster}

Datainnsamling ved hjelp av videoobservasjon er etter hvert blitt en etablert måte å dokumentere pedagogisk forskning på. Video som verktøy kan benyttes fleksibelt (Blikstad-Balas, 2017; Sahlström, 2008). Avhengig av forskningsformål kan forskeren, ved hjelp av videoobservasjoner, for eksempel rekonstruere komplekse øyeblikk og sekvenser av handlinger. Det er mulig å kunne dokumentere sekvenser med høy grad av validitet ettersom opptakene kan spilles av gjentatte ganger, og forskeren kan gjennomgå samme segmenter også ved hjelp av ulike analytiske fokus (Heath et al., 2010). Gjennom videoopptak kan det også registreres tid og lengde på sekvenser, dersom en for eksempel ønsker å utforske rekkefølge i hendelser, eller variasjoner i tidsbruk med tanke på bestemte hendelser i en undervisningssituasjon (Rønning et al., 2013). Øyeblikk i opptakene kan fryses for å kunne studeres mer nøyaktig, og det er mulig å variere hastighet i avspillingen for å kunne studere enkeltsituasjoner eller sekvenser grundig, dersom det er behov for å avdekke gjentakelser eller mønstre (Jewitt, 2012; Simpson et al., 2013). I tillegg er videoopptak mulig å dele med andre forskere, slik at sekvenser i materialet kan observeres og diskuteres for å få ulike synspunkter på det som observeres, noe som kan øke validiteten av forskningen (Creswell, 2013; Derry et al., 2010).

Selv om fokus og omfang i en videostudie gjerne styres av forskerens interesser, vil forskeren stå overfor en rekke valg i ulike faser av forskningsprosessen. Valgene gjør seg gjeldende både i forbindelse med 
planlegging av studien, hvilke typer av opptak som skal foretas, hvilke klipp fra opptakene som skal brukes, hvilke sammensetninger av klipp som skal gjøres i tråd med studiens formål, hvordan studien skal presenteres og hvordan opptakene skal arkiveres (Derry et al., 2010, s. 8). Dette utgjør viktige, overordnede valg.

Bruk av video som verktøy i læringskontekster kan bidra til at forskeren får nøyaktige og nære dokumentasjoner av forskningsfeltet. I det følgende drøftes noen av de metodiske valgene som synes å være spesielt viktige når det gjelder ulike former for videoobservasjoner, uavhengig av læringskontekster, og som omhandler de ovenfor nevnte aspektene utvalg, teknologi, etikk og analyse.

\section{Utvalg}

Utvalg kan i vid forstand omhandle alle valg og begrunnelser forskeren gjør når det gjelder hva som skal inkluderes eller ekskluderes, fra planlegging og til representasjon og rapportering av studien. Videoobservasjoner gir mulighet for å fokusere på prosesser, og på potensialet i det som produseres og konstrueres av tekst eller data i læringskontekstene (MikMeyer \& Järvinen, 2005, s. 19). Når former for interaksjoner studeres, er mening som konstrueres gjennom de konkrete og observerbare videoobservasjonene mer sentral enn å utforske aktørers subjektive oppfatninger. Faktorene spiller inn når det skal tas stilling til utvalg i videostudier, fordi et sentralt spørsmål blant annet vil være hva videoobservasjoner vil kunne bidra med når opptakene skal analyseres. Utvalg henger på denne måten sammen med hvilke spesifikke deler av det komplekse forskningsområdet som det skal gjøres videoopptak av.

Ettersom videoteknologi er i stadig utvikling, øker videoforskeres muligheter for å kunne studere mer og mer detaljerte videoobservasjoner. Den mulige detaljeringsgraden i videoobservasjoner gjør at det er viktig for forskeren å ha et reflektert forhold til et ofte komplekst utvalg av data, samt til hva som eventuelt må velges bort (Blikstad-Balas, 2017; Snell, 2011). Dette for å sikre nødvendig bredde og dybde, og at det er klare sammenhenger mellom utvalg, studiens formål og forskningsspørsmål, samt vitenskapsteoretiske og metodiske perspektiver. 


\section{Teknologi}

Teknologi kan her forstås som de teknologiske verktøyene forskeren har tilgjengelig. I tillegg omhandler teknologi de tilleggsverktøyene som forskeren må utvikle, eller gjøre tilgjengelig, for å støtte ulike sider ved forskningsprosessen, som for eksempel datainnsamling og analyse, og verktøy som omhandler utvikling og deling av videosekvenser. Lovverk som gjelder behandling av videoobservasjoner kan også relateres til teknologi og det benyttede verktøyets mulighet for å gjøre relevante observasjoner. I dag finnes det et rikt utvalg av verktøy for videoobservasjoner. Verktøyene er i stadig utvikling, og gir muligheter for mer og mer «finmaskede» og målrettede observasjoner (Blikstad-Balas, 2017; Sahlström, 2008). Fordi en i videoanalyse spesielt har rettet oppmerksomheten mot den observerbare atferden (Knoblauch, 2008), er det avgjørende at det tekniske utstyret som velges, faktisk gir muligheter for å fokusere spesifikt på områder ved den observerbare atferden som står i sammenheng med studiens formål. Problemstillinger og forskningsspørsmål bør derfor være retningsgivende for hvilket utstyr forskeren tar i bruk, ettersom utstyret er med på å avgjøre i hvilken grad kvaliteten på datamaterialet gir mulighet for å få svar på studiens forskningsspørsmål. Innenfor videoforskning er i tillegg forskerens tekniske ferdigheter sentrale for å håndtere verktøyet i forbindelse med observasjonene. De tekniske ferdighetene retter seg for eksempel mot valg av verktøy, plassering for opptak av lyd og bilde, lengde på opptak, innstillinger med tanke på fokusering, med mer. Forskerens kunnskaper om hvilke verktøy som er best egnet for formålet, og ferdigheter i hvordan verktøyet benyttes, kan dermed ha betydning for validiteten og reliabiliteten i det som studeres.

Validitet i videoanalyse kan sees i sammenheng med om det er mulig å trekke gyldige slutninger ut fra observasjonene. Dette innebærer blant annet om resultatene er gyldige for det utvalget og fenomenet som er undersøkt, og om resultatene er mulige å overføre til andre utvalg og situasjoner. Reliabilitet i videoanalyse omhandler analysens etterprøvbarhet, dvs. om andre forskere kan benytte begrepsapparatet for analyse av data på samme måte som den opprinnelige forskeren. Teknologien som velges for videoobservasjon kan dermed både fremme og hemme kvaliteten i observasjonene, og sammen med forskerens kunnskaper om 
bruk av teknologien, er det derfor grunn til å reflektere kritisk over på hvilke måter videoobservasjonene kan og bør benyttes som forskningsdatamateriale. Et annet kritisk moment i denne sammenheng omhandler kjerneområdene som velges ut for observasjon. I dagens høyteknologiske samfunn er det mange muligheter når det gjelder teknologiske hjelpemidler som kan gjøre videoobservasjoner svært autentiske og anvendbare. Et sentralt spørsmål er dermed hva som styrer forskerens valg av fokus i observasjonene, med de tilgjengelige mulighetene som finnes. Dette innebærer blant annet om de valgte områdene for observasjon bidrar til å gi et bilde av læringskonteksten slik den faktisk er, eller om det i større grad er forskerens interesser som avgjør hva som skal legges vekt på. Et aspekt i denne sammenhengen vil dermed være hva som ligger til grunn for forskerens forståelse av læringskonteksten, og at konklusjoner som trekkes er basert på det grunnlaget en kan si noe om, med en klar bevissthet om hva funnene ikke sier noe om (Dalland et al., 2018).

Samtidig som forskerens interesser på mange måter kan anses som selvsagt i valg av tema for videoobservasjoner, vil diskusjonen om balansen mellom forskerens interesser og hva som utgjør et faktisk bilde av læringskonteksten, være sentral innenfor videoforskning. Et perspektiv som også er viktig i denne sammenhengen, er at en ved å rigge opp teknisk utstyr for videoobservasjon i klasserom også står i fare for å påvirke læringskonteksten bare gjennom utstyret, slik at situasjonen som skal undersøkes kan endres og dermed ikke gi adekvate observasjoner. Blikstad-Balas (2017) omtaler faren for påvirkning gjennom utstyret, som kameraeffekt (s. 514-515), og hevder at denne likevel ikke utgjør en mer alvorlig ulempe enn andre forskningsmetoder, ettersom en forskningssituasjon i seg selv, uavhengig av forskningsmetode, vil kunne ha en viss effekt på de situasjonene som skal skildres. Samtidig er perspektivene viktige å ha et bevisst forhold til, også fordi de berører etiske aspekter i videoforskning, noe vi tar for oss i det følgende.

\section{Etikk}

Boeije (2014) peker på viktigheten av forskerens vurdering av moralsk nøyaktighet i forskningsaktivitet. Økende bruk av video i læringskontekster, 
og mangfoldet av muligheter som finnes med tanke på teknologiske verktøy, gjør det relevant å diskutere etiske aspekter ved videoobservasjoner i læringskontekster.

De nasjonale etiske retningslinjene for forskning (NESH, 2018) danner en sentral basis for videoforskningen i Norge. Etikk omhandler i denne sammenheng hvordan forskeren ser muligheter for å kunne utnytte videomaterialet på flere, og ulike, måter, samtidig som deltakernes rettigheter ivaretas. I dagens teknologiske samfunn er mulighetene nærmest uendelige når det gjelder opptak, lagring og distribuering av video. Det etiske aspektet i videoforskning står dermed svært sterkt. De som deltar i videoforskning skal for eksempel være informert om hva deltakelse innebærer, at de har mulighet for å trekke seg underveis, og at deres rettigheter til personvern ivaretas. Videoopptak i læringskontekster kan innebære at barn, eller personer fra sårbare grupper involveres (Hanssen, 2018; Tverbakk 2018; Valle, 2014). Dette stiller ekstra krav til at deltakerne blir forklart hva deltakelsen innebærer på måter den enkelte deltaker forstår, eller at deltakeren får hjelp av ansvarlige voksne til å ta beslutningen om å være med i studien (Derry et al., 2010, s. 34).

Forskerens kunnskap om de til enhver tid gjeldende etiske retningslinjene, kan ha stor betydning for inngangen til forskningsfeltet, og for tilgangen til relevante data. Etiske retningslinjer kan tolkes ulikt innenfor ulike organisasjonskulturer. For å unngå at mulighetene for forskningen begrenses, er det derfor viktig at prosjekter som benytter videoobservasjoner har solid forankring i gjeldende etiske prinsipper og forskrifter for forskningen. Videoobservasjoner kan gi ulike muligheter for tolkning. En tydeliggjøring av observasjonenes formål og utgangspunkt kan ha betydning for om materialet analyseres i tråd med hensikten, og ikke går ut over de rammene som opprinnelig ble satt for undersøkelsen. Dette kan også innebære at en må tolke ordinære normer og regler for etiske hensyn med varsomhet, fordi analyseenheten kan utfordre etiske aspekter på en særlig måte. De etiske valgene forskeren gjør, har dermed også betydning for analysen av datamaterialet. 


\section{Analyse}

Analyse av videodata kan betegnes som en rekursiv prosess (Derry et al., 2010) som innebærer gjentatte bevegelser frem og tilbake i sekvensene i materialet for å utvikle tolkninger av innholdet. Ifølge Knoblauch (2008) innebærer analyse å identifisere enheter av handlinger i deres innbyrdes sammenheng i den sekvensen de er en del av. Erfaringer viser at ettersom videoobservasjoner inneholder komplekse mengder med detaljer, kan relevante forskningsspørsmål fungere som strukturerende retningslinjer for analysen. Samtidig må forskeren være åpen for at kompleksiteten i materialet også kan avdekke mer uventede funn som forskeren må ta stilling til i en analyseprosess. Uventede funn i videoobservasjoner kan for eksempel åpne for større bredde i forskningen som utføres, eller åpne for nye innfallsvinkler i flere studier. Verktøyet gir også muligheter for at flere forskere studerer deler av observasjonene og diskuterer mulige tilnærminger i segmentene, noe som gjør at materialet kan utnyttes til flere formål og på ulike tidspunkt. De rike mulighetene for ulike perspektiver i analysen, er noe av styrken ved videoobservasjoner. Mulighetene stiller også krav til at forskeren må kunne håndtere at analysene kan avdekke nye eller andre formål, problemstillinger og tema som kan være interessante, og ta stilling til hensiktsmessige, videre valg. Video kan gi innsyn i ulike og komplekse aspekter ved interaksjoner - som blikk, bevegelser, dialoger mellom mennesker, stemmeleie, ansiktsuttrykk, kroppsholdninger, avstand og nærhet, bruk av redskaper, samt hvordan mennesker forholder seg til hverandre i en gitt kontekst (Derry et al., 2010). Relevante tilnærminger for hva som skal få oppmerksomhet i analysen ut fra forskningsspørsmål og formål, og hvordan innholdet i opptakene skal representeres eller synliggjøres, er blant de beslutningene forskeren må ta i betraktning i planlegging av analysen.

Knoblauch (2008) peker på at en kan forenkle variasjonene i videoanalyse til den standardiserte og den fortolkende videoanalysen (s. 8). Den standardiserte videoanalysen baserer seg på at forskeren utvikler deduktive koder som kategoriseres på forhånd. Dette innebærer at forskeren tar utgangspunkt i relevant programvare eller teori, og forhåndsbestemmer koder som konstrueres i relasjon til et reliabelt kategoriseringssystem. Disse kodene anvendes på de audiovisuelle opptakene for å fange opp 
eller eventuelt avdekke mangler i bestemte hendelser eller prosedyrer. Den fortolkende videoanalysen skiller seg markant fra den standardiserte videoanalysen, og tar på den andre siden utgangspunkt i aktørers visuelt observerbare atferd i videoopptakene. I fortolkningen forholder forskeren seg mer induktivt til handlingene i sekvensene, med bakgrunn i hva som er handlingens mening eller hensikt (Knoblauch, 2008).

Den fortolkende videoanalysen omtales av Knoblauch (2008) som videografi, og sees i sammenheng med at metoden kan betraktes som en form for videosentrert etnografi hvor sekvensene i videoanalysen legger særlig vekt på den visuelt observerbare atferden. Innenfor videografi studeres visuelle data i lys av den sosiale konteksten som dataene er en del av. Ved at metoden er fortolkende, åpnes muligheter for at forskeren gjennom observasjonene kan identifisere og utforske objektive mønstre i de sosiale aktivitetene som gjennomføres. Det er altså ikke den enkelte aktørs subjektive mening som er gjenstand for utforsking, men hvordan aktørenes handlinger interagerer og påvirkes av den sosiale konteksten. Erickson (2006) omtaler den induktive tilnærmingen i videoanalyse som den kanskje mest benyttede.

I en innledende fase i analysen kan det være nyttig å gjøre foreløpige kartlegginger av hva som kan være relevant for transkripsjon, hvilken form for transkripsjon som kan være hensiktsmessig, samt detaljnivå (Derry et al., 2010). Feltnotater eller loggføring av hendelser under og like etter observasjonen, kan bidra til å bli kjent med hvilke deler av materialet som kan være interessant å gå nærmere inn på i en mer systematisk koding. Andre måter å skaffe seg oversikt over materialet kan for eksempel være å lage former for flytskjema, diagrammer eller utvikle narrative beskrivelser av utvalgte hendelser som kan utdype spesifikke deler av observasjonene for det videre kodingsarbeidet. Ettersom forskeren kan studere opptakene flere ganger og med ulike perspektiv, kan transkripsjonene justeres i tråd med hva forskeren etter hvert anser for å gi best mulig svar, eller hva som er mest relevant for studien. Avhengig av hva forskeren er opptatt av å analysere, utvikles det systemer for transkripsjon som kan inkludere ulike former for interaksjoner hvor aspekter ved kommunikasjon og handling står sentralt, for eksempel gjennom verbalt språk, pauser, kroppsspråk, bevegelser osv. Valg av systemer for transkripsjon 
har blant annet sammenheng med elementer som forskningsspørsmål, teoretisk innretning i studien og relevante transkripsjonskonvensjoner (Derry et al., 2010).

Med noen unntak, transkriberes de delene av datamaterialet som representerer hendelsene som forskeren ønsker å undersøke nærmere. Ved å for eksempel transkribere innledninger til hendelser, kan forskeren få mulighet til å identifisere overganger mellom feltnotater og videoobservasjon for å utlede om, og eventuelt hvordan, en skal legge opp analysen, mens en i senere stadier av transkripsjonen kan foreta en mer selektiv utvelgelse av observasjonene, til en har oversikt over hva som fremstår som mest relevant i materialet (Derry et al., 2010, s. 19-20). I tilfeller hvor forskeren velger å transkribere større deler av datamaterialet, kan årsaken være ønske om å gå mer åpent ut i feltet, for eksempel dersom feltet er mindre utforsket, eller at en ønsker å ha mulighet for å se etter andre, mulige relevante elementer for studien i tillegg (Dalland et al., 2018).

De metodiske fasene utvalg, teknologi, etikk og analyse som er gjort rede for ovenfor, er som tidligere nevnt vektlagt fordi de, uavhengig av fag eller metodologisk tilnærming, har innflytelse på videoforskning innenfor læringskontekster (Derry et al., 2010). Videoobservasjoner av læringskontekster kan knyttes til ulike vitenskapsfilosofiske retninger som etnografi, etnometodologi, eksperimentering, diskursanalyse, interaksjonsanalyse m.m. (Derry et al., 2010, s. 5), og det vil være ulike formål med forskning knyttet til læringskontekster. Læringskontekster relateres i dette kapitlet som nevnt til forskerens bruk av videoobservasjoner for utforsking av sider ved undervisning og læring. Uavhengig av hvilken vitenskapsfilosofisk retning forskningen knyttes til, kan det som studeres gjennom videoobservasjonene sees i sammenheng med sosial samhandling i læringskontekstene, og former for interaksjoner mellom aktører. De metodiske aspektene som er omtalt ovenfor kan i mange tilfeller også sees på som generelle, og er viktige å ta hensyn til også ved bruk av andre datainnsamlingsmetoder. Det kan derfor være hensiktsmessig å se mer spesifikt på hvordan en kan fokusere videoobservasjoner i læringskontekster inn mot ulike områder for interaksjoner, som kan fungere som tilganger i analysearbeidet. 


\section{Mulige metodologiske tilganger til videoobservasjoner}

Tilganger kan forstås som mulige perspektiver på analyser, det vil si på hvilke måter forskeren velger å avgrense områdene i analysen av observasjonsmaterialet, med tanke på interaksjonene, eller samhandlingsformene mellom aktørene. I dette kapitlet er de avgrensede områdene inspirert av Järvinen og Mik-Meyers (2005) beskrivelser av mulige avgrensninger, som kan rettes mot praksis, institusjoner, sosiale identiteter, talehandlinger og en objektivert virkelighet.

Oppmerksomhet rettet mot praksis i analyser av læringskontekster, omhandler studier hvor formålet er å utforske de sosiale aktivitetene som læringsaktivitetene inneholder, for å kunne identifisere hvordan aktørene produserer gjenkjennelige mønstre i læringskonteksten. Det er dermed ikke et formål å analysere forskningsområdet for å beskrive læringsaktivitetene slik de er, men mer å se nærmere på interaksjonen mellom aktørene, som for eksempel lærer og elever i en undervisningssituasjon, eller elevers interaksjoner med læringsverktøy i undervisningssituasjoner, og hvordan konteksten virker inn på interaksjonen (Rusk \& Rønning, 2020). Det tas utgangspunkt i hvordan aktørene konstituerer læringskonteksten, og ikke i hvordan læringskonteksten er konstituert for aktørene (Järvinen \& Mik-Meyer, 2005, s. 100). Eksempler på studier som tar utgangspunkt i praksis i sine analyser, finner vi blant annet i BlikstadBalas' studie av elever i videregående skole og deres bruk av internett $i$ ulike fag, mens lærerne har digitale presentasjoner (Blikstad-Balas, 2015). Analysene baserer seg blant annet på utforsking av videoopptak av elevers lese- og skrivepraksiser ved hjelp av digitale verktøy under lærernes forelesninger, og hva elevene bruker tiden på i undervisningssituasjonen. Gjennom samtaler og analyse av interaksjoner av hvordan jevnaldrende ungdomstrinnselever organiserte sitt sosiale samspill og samarbeid i gruppearbeid om lærergitte oppgaver, kunne for eksempel Rusk og Rønning (2020) gjøre mikroanalyser av videodata for å utlede sentrale faktorer som kan påvirke læring i denne typen samarbeid. En lignende studie er foretatt av Bjørkvold og Krogstad Svanæs (2021), som undersøkte elevers skrivepraksiser på 1. og 2. trinn ved bruk av nettbrett med 
talesyntese. Forskerne benyttet her både videoobservasjon, skjermobservasjon og elevtekster for å utforske elevenes skrivehandlinger og deres motivasjon for handlingene, og resultatene viste for eksempel at elevene var svært oppmerksomme på ortografi og tekstlengde, samtidig som de også var opptatt av samhandling med jevnaldrende om deres tekster. Videoobservasjoner viser seg som svært anvendelige måter å innhente data fra læringskontekster, og er også benyttet på flere andre klasseromsstudier som er innrettet mot sider ved praksiser (Magnusson, 2020; Stovner et al., 2021).

Når oppmerksomheten rettes mot institusjoner, omhandler det alt fra former for organisasjoner, til vanebundne handlemønstre (Järvinen \& Mik-Meyer, 2005, s. 99). Institusjon kan dermed både innbefatte tradisjonelle, fysiske eller organisatoriske institusjoner, men også etablerte rutiner og vaner innenfor læringskontekster. Det kan omhandle analyser av skolen som organisasjon og ulike rutiner for gjennomføring av undervisning, for eksempel ved å analysere videoobservasjoner av undervisningssituasjoner der hensikten er å undersøke hvordan læringssyn i læreplaner kommer til uttrykk i ulike skoler og klasseromskontekster (Hodgson et al., 2012). Formål med slike studier er gjerne utforsking av relasjoner mellom aktørenes praksis og den institusjonelle konteksten aktørene interagerer med. Vektlegging av utforsking av institusjonssiden er kjent gjennom blant annet Goffman (1971), som tar utgangspunkt $\mathrm{i}$ at den institusjonelle konteksten bidrar til å skape rammer som både kan danne muligheter, men også begrensninger for den sosiale interaksjonen. Et sentralt poeng i Goffmans forskning er at aktører i en sosial interaksjon skaper en form for moralsk orden som er relatert både til de sosiale identitetene som produseres i den sosiale interaksjonen, og som også er relatert til strukturer i samfunnet (Goffman, 1971, s. 222). Omgivelsene, eller kontekstene som den sosiale interaksjonen er en del av, kan dermed bidra til å ramme inn eller påvirke konversasjonen mellom aktører (Drew \& Heritage, 1992; Goffman, 1971; Miller, 1994).

Sosiale identiteter omhandler utforsking av hvordan ulike identiteter konstrueres ved at individene deltar i sosiale interaksjoner, og hvordan individene posisjonerer seg på den sosiale arenaen med bakgrunn i det 
institusjonelle repertoaret de besitter (Järvinen \& Mik-Meyer, 2005). Harré (2001) peker på at en persons posisjon kan ses på som et utgangspunkt, eller et sett av ressurser, som former personen selv i en bestemt kontekst. Innenfor læringskontekster vil ulike aktører posisjonere seg på ulike måter, eller det kan knyttes ulike forventninger til aktører, avhengig av posisjoner innenfor ulike nivå. Samtidig vil posisjoner være dynamiske fordi de er mulige å transformere, utfordre og utnytte gjennom ulike interaksjoner. Utforsking av hvordan ulike interaksjoner påvirker læreres posisjoner og utvikling av profesjonelle identiteter, kan være eksempler på forskningsformål rettet mot sosiale identiteter. Andre eksempler kan være studier som har benyttet videoobservasjoner for å støtte opp om utviklingsarbeid og pedagogers læring ved skoler eller andre pedagogiske institusjoner (Charbonneau-Gowdy, 2015; Tengberg \& Wejrum, 2021).

Analyse av konversasjoner eller samtaler sees på som en sentral tilgang til observasjonsmateriale. Konversasjoner og språk er ikke nødvendigvis noe som er konstituert av en individuell eller sosial virkelighet, men språket bidrar til å konstituere selve den sosiale og individuelle virkeligheten (Potter, 2000). Meningsaspektet i samtaler oppstår i samhandling, og speiler derfor ikke primært de mentale prosessene hos den enkelte aktør. Samtalene kan analyseres som utsagn, men kan også analyseres som handlinger med en eller flere bestemte funksjoner. Dette innebærer å analysere hva aktørene gjør gjennom det de sier, og hvilke resultater samtalene kan føre til. Med bakgrunn i samtalers resultater, peker Potter (2000) på muligheten for å se på utsagnenes retoriske organisering. Det vil si at ved at den sosiale virkeligheten formes av sosial interaksjon, vil noen utsagn statueres som mer virkelige og betydningsfulle enn andre, og ulike utsagn kan dermed sees på som konkurrerende. I dette perspektivet vil formålet med analyse av samtalers retoriske organisering være å utforske konstruksjoner av hvordan virkeligheten konstrueres og bidrar til overbevisning (Simons, 1990, s. 11). I studier av læringskontekster vil tilgang til observasjonsmateriale gjennom analyser av konversasjoner for eksempel kunne bidra til utvikling av kunnskap om læring og kognisjon som sosiale fenomen (Rusk et al., 2014). Å studere samtaler innenfor læringskontekster gir muligheter for å utforske læringsfellesskap 
gjennom mange ulike perspektiver på samhandling (Hummelstedt et al., 2021; Klette et al., 2018; Sahlström et al., 2019).

\section{Implikasjoner for forskerrollen}

I dette kapitlet har vi tatt for oss noen av de mulighetene video som metodisk verktøy kan bidra med. Samtidig som det på flere måter er naturlig at forskningen styres av forskerens interesser, i hvert fall i mindre studier, ligger det et stort ansvar i det å presentere forskning med utgangspunkt i videostudier. På mange måter synliggjør metodens allsidighet og de mange tilgjengelige formene for observasjonsverktøy som finnes, fra de enkle og til de mest avanserte, at verktøyet er anvendelig, og at det derfor ikke nødvendigvis krever at forskeren har avanserte kunnskaper om utstyret. Uavhengig av prosjekt vil det likevel være avgjørende at valg av utstyr relateres til den enkelte studies forskningsspørsmål og formål, og hva som ut fra det vil gi best mulig tilgang til det som skal studeres. I tillegg til utstyrets generelle muligheter, er det knyttet en rekke allmenne metodiske valg opp mot det å benytte video som forskningsmetode; for eksempel utvalg, teknologi, etikk og analyse. Selv om aspektene her er beskrevet hver for seg, synes de å være vevd inn i hverandre som en uløselig del av de valgene videoforskeren må tenke gjennom i planlegging og gjennomføring av videoforskningsprosjekt. Samtidig vil videoforskeren kanskje også erfare at noen av aspektene, avhengig av prosjekt, nødvendigvis vil være mer fremtredende enn andre. I tillegg til de nevnte metodiske valgene forskeren står overfor, kan mer metodologiske avgrensninger av studiers fokusområder fungere som hensiktsmessige tilganger for å ramme inn studienes analyser. Avgrensningene disse fokusområdene utgjør, kan ha glidende overganger; en studie av for eksempel talehandlinger, kan også være rettet inn mot studier av praksis. De metodologiske avgrensningene kan dermed, sammen med de metodiske vurderingene, også bidra til å skape ramme og retning i håndtering av videodatamateriale $\mathrm{i}$ læringskontekster. 


\section{Referanser}

Baustad, A. G. \& Bjørnestad, E. (2020). Everyday interaction between staff and children aged 1-5 in Norwegian ECEC. Early Years, 1-15. https://doi.org/10.1080/ 09575146.2020.1819207

Bjørkvold, T. \& Svanes, L. K. (2021). Writing practices on tablets with speech synthesis in grade 1 and 2. International Journal of Education Research, 107, 101742. https://doi.org/10.1016/j.ijer.2021.101742

Blikstad-Balas, M. (2015). Digital literacy in upper secondary school - what do students use their laptops for during teacher instruction? Nordic Journal of Digital Literacy, 7(2), 81-96. https://doi.org/10.18261/ISSN1891-943X-2012-02-01

Blikstad-Balas, M. (2017). Key challenges of using video when investigating social practices in education: Contextualization, magnification, and representation. International Journal of Research \& Method in Education, 40(5), 511-523. http:// dx.doi.org/10.1080/1743727X.2016.1181162

Boeije, H. (2014). Analysis in qualitative research. Sage.

Charbonneau-Gowdy, P. (2015). Teacher research in video-based online classrooms. I S. Borg \& H. Sanchez (Red.), International perspectives on teacher research (s. 57-69). Macmillan Distribution.

Creswell, J. W. (2013). Qualitative inquiry and research design: Choosing among five approaches (3. utg.). Sage.

Dalland, C. P., Klette, K. \& Svenkerud, S. (2018). Video studies and the challenge of selecting time scales. International Journal of Research \& Method in Education, 43(1), 53-66. https://doi.org/10.1080/1743727X.2018.1563062

Derry, S. J., Pea, R. D., Barron, B., Engle, R. A., Erickson, F., Goldman, R., Hall, R., Koschmann, T., Lemke, J. L., Sherin, M. G. \& Sherin, B. L. (2010). Conducting video research in the learning sciences: Guidance on selection, analysis, technology, and ethics. Journal of the Learning Sciences, 19(1), 3-53. https://doi.org/10.1080/10508400903452884

Drew, P. \& Heritage, J. (1992). Talk at work. Interaction in institutional settings. Cambridge University Press.

Erickson, F. (2006). Definition and analysis of data from videotape: Some research procedures and their rationales. I J. L. Green, G. Camilli \& P. B. Elmore (Red.), Handbook of complementary methods in education research (s. 177-205). Erlbaum.

Gaudin, C. \& Chaliés, S. (2015). Video viewing in teacher education and professional development: A literature review. Educational Research Review, 16, 41-67. https://doi.org/10.1016/j.edurev.2015.06.001

Goffman, E. (1971). The presentation of self in everyday life. The Penguin Press.

Hanssen, N. B. (2018). Special educational needs practices in Norwegian and Belarusian preschools [Doktorgradsavhandling]. Nord universitet. 
Harré, R. (2001). The discoursive turn in social psychology. I D. Shiffrin, D. Tannen \& H. E. Hamilton (Red.), The handbook of discourse analysis (s. 688-706). Blackwell.

Hatlevik, O. E. \& Egeberg, G. (2014). Challenges arising when using field notes and video observations: A close study of teachers' use of interactive whiteboards in a Norwegian school. I G. B. Gudmundsdottir \& K. B. Vasbø (Red.), Methodological challenges when exploring digital learning spaces in education (s. 79-94). Brill.

Heath, C., Hindmarsh, J. \& Luff, P. (2010). Video in qualitative research: Analysing social action in everyday life. Sage.

Hodgson, J., Rønning, W. \& Tomlinson, P. (2012). Sammenhengen mellom undervisning og loering. En studie av loereres praksis og deres tenkning under Kunnskapsløftet (NF-rapport 4/2012). Nordlandsforskning.

Hummelstedt, I, Holm, G., Sahlström, F. \& Zilliacus, H. (2021). 'Refugees here and Finns there' - categorisations of race, nationality, and gender in a Finnish classroom. Intercultural Education, 32(2), 145-159.

Jewitt, C. (2012). An introduction to using video for research. National Center for Research Methods. http://eprints.nrcm.ac.uk/2259/

Järvinen, M. \& Mik-Meyer, N. (2005). Observationer i en interaktionistisk begrebsramme. I M. Järvinen \& N. Mik-Meyer (Red.), Kvalitative metoder $i$ et interaksjonistisk perspektiv. Interview, observationer og documenter (s. 97-120). Hans Reitzels Forlag.

Klette, K., Blikstad-Balas, M. \& Roe, A. (2017). Linking instruction and student achievement. A research design for a new generation of classroom studies. Acta Didactica Norge, 11(3). https://doi.org/10.5617/adno.4729

Klette, K., Sahlström, F., Blikstad-Balas, M., Luoto, J., Tanner, M., Tengberg, M., Roe, A. \& Slotte, A. (2018). Justice through participation: Student engagement in Nordic classrooms. Education Inquiry, 9(1), 57-77. https://doi.org/10.1080/200045 08.2018 .142803

Knoblauch, H. (2008). Videografi: Å tolke samhandling i kontekst. Sosiologi i dag, $38(2)$. http://ojs.novus.no/index.php/SID/article/view/942

Magnusson, C. M. (2020). Reading literacy practices in Norwegian lower-secondary classrooms: Examining the patterns of teacher questions. Scandinavian Journal of Education Research, 65(5), 1-15. https://doi.org/10.1080/00313831.2020.1869078

Mik-Meyer, N. \& Järvinen, M. (2005). Innledning. I M. Järvinen \& N. Mik-Meyer (Red.), Kvalitative metoder i et interaksjonistisk perspektiv. Interview, observationer og dokumenter (s. 9-24). Hans Reitzels Forlag.

Miller, G. (1994). Toward ethnographies of institutional discourse. Journal of Contemporary Ethnography, 23(3), 280-306. https://doi.org/10.1177/0891241940 23003002 
NESH. (2018, 4. desember). Forskningsetiske retningslinjer for samfunnsvitenskap, humaniora, juss og teologi. https://www.forskningsetikk.no/retningslinjer/humsam/forskningsetiske-retningslinjer-for-samfunnsvitenskap-humaniora-juss-ogteologi/

Potter, J. (2000). Representing reality. Discourse, rhetoric and social construction. Sage.

Rusk, F., Pörn, M., Sahlström, F. \& Slotte-Lüttge, A. (2014). Perspectives on using video recordings in conversation analytical studies on learning in interaction. International Journal of Research \& Method in Education, 38(1), 39-55. https://doi. org/10.1080/1743727X.2014.903918

Rusk, F. \& Pörn, M. (2019). Delay in L2 interaction in video-mediated environments in the context of virtual tandem language learning. Linguistics and Education, 50, s. 56-70. https://doi.org/10.1016/j.linged.2019.02.003

Rusk, F. \& Rønning, W. (2020). Group work as an arena for learning in STEM education: Negotiations of epistemic relationships. Education Inquiry, 11(1), 36-53. https://doi.org/10.1080/20004508.2019.1638194

Rønning, W., Hodgson, J. \& Tomlinson, P. (2013). Å se og bli sett. Klasseromsobservasjoner av intensivopplaeringen i Ny giv (Rapport nr. 6/2013). Nordlandsforskning.

Sahlström, F. (2008). Från lärare till elever, från undervisning till lärande utvecklingslinjer i svensk, nordisk og internationell klassrumsforskning (Vetenskapsrådets rapportserie 9/2008). Vetenskapsrådet.

Sahlström, F., Tanner, M. \& Valasmo, V. (2019). Connected youth, connected classrooms. Smartphone use and student and teacher participation during plenary teaching. Learning, Culture and Social Interaction, 21, 311-331. https://doi. org/10.1016/j.lcsi.2019.03.008

Seidel, T. \& Thiel, F. (2017). Standards und Trends der videobasierten LehrLernforschung. Zeitschrift für Erziehungswissenschaft, 20(1), 1-21. https://doi. org/10.1007/978-3-658-15739-5_1

Simons, H. W. (1990). The rhetorical turn: Invention and persuasion in the conduct of inquiry. University of Chicago Press.

Simpson, A., Walsh, M. \& Rowsell, J. (2013). The digital reading path: Researching modes and multidirectionality with iPads. Literacy, 47(3), 123-130. https://doi.org/ 10.1111/lit.12009

Snell, J. (2011). Interrogating video data: Systematic quantitative analysis versus micro-ethnograpic analysis. International Journal of Social Research Methodology, 14(3), 253-258. https://doi.org/10.108o/13645579.2011.563624

Stovner, R. B., Klette, K. \& Nortvedt, G. A. (2021). The instructional situations in which mathematics teachers provide substantive feedback. Educational Studies in Mathematics, 107(2), 1-19. https://doi.org/10.1007/s10649-021-10065-w 
Tengberg, M. \& Wejrum, M. (2021). Observation och återkoppling med fokus på utvecklad undervisning: Professionsutveckling med hjälp av PLATO. Acta Didactica Norden, 15(1). http://dx.doi.org/10.5617/adno.7985

Tuma, R., Knoblauch, H. \& Schnettler, B. (2014). Videography: Introduction to interpretive videoanalysis of social situations. Springer.

Tverbakk, M. (2018). Loereres lesedidaktiske praksiser: En studie av lesing i norsk, naturfag og samfunnsfag på ungdomstrinnet [Doktorgradsavhandling, Nord universitet]. Nord Open. http://hdl.handle.net/11250/2579484

Valle, A. M. (2014). Lererens intuitive handlingskompetanse [Doktorgradsavhandling]. Nord universitet.

Yousef, A. M. F., Chatti, M. A. \& Schroeder, U. (2014). The state of video-based learning: A review and future perspectives. International Journal on Advances in Life Sciences, 6(3/4), 122-135. 


\title{
Etiske aspekter ved videoforskning i et lite miljø
}

\section{Sandra Nystø Ráhka}

Fakultet for lærerutdanning og kunst- og kulturfag, Nord universitet, Bodø

\begin{abstract}
Ethical research is more than following ethical guidelines and gaining consent for your research project. The more complex and often unpredictable ethical issues often only arise once out in the field. The purpose of this chapter is to discuss such ethical dilemmas. The point of departure is a research project where video data of various learning activities was employed to develop knowledge about teaching practice in Sámi education. This is a limited but complex research context as Sámi education can happen in different forms and with various numbers, sometimes quite small, of students from school to school. Such a small research context requires thorough ethical consideration and makes ethical dilemmas extra pertinent. From the very beginning it was clear that special consideration had to be made in terms of recruitment, consent, confidentiality and researcher positioning. The aim of this chapter is to discuss the considerations that had to be made to ensure an ethically responsible data collection. We experienced the national ethical guidelines to be a good starting point for this. In addition we benefited from central aspects of Indigenous methodologies. Indigenous methodologies are fundamentally ethical ways to do research. Knowledge about research in Indigenous contexts can lead to a more ethically responsible research, regardless of research field.
\end{abstract}

Keywords: research ethics, researcher positioning, national ethical guidelines, Indigenous methodologies

\section{Introduksjon}

Forskningsetikk dreier seg om etiske normer, verdier og prinsipper for redelig og ansvarlig forskningspraksis. Det handler om de valgene man gjør som forsker; om alt fra valg av forskningsfelt og problemstilling til rekruttering av deltakere og metoder for datainnsamling, samt hvordan kunnskapen du opparbeider blir forvaltet og formidlet. I Norge reguleres 
forskningen av både forskningsetiske retningslinjer og juridiske lover (NESH, 2018). Mens retningslinjene er ment å være veiledende for forskeren i kraft av at de angir hva forskeren bør ta hensyn til for at forskningen skal være ansvarlig, forplikter eksempelvis personopplysningsloven (2018) forskeren til å ivareta personvernet til de som deltar i forskningen. Begge deler ivaretar grunnleggende etiske prinsipper som informasjonsplikt, samtykke og konfidensialitet, men forskningsprosjekter der personopplysninger behandles, er meldepliktige, og må forhåndsgodkjennes av personvernombudet for forskning (NESH, 2018). Dette er en søknadsprosess som betinger at forskeren grundig overveier og prøver å forutse mulige etiske problemstillinger som kan oppstå i prosjektet. Som regel får man prosjektet godkjent, men det betyr selvsagt ikke at de etiske sidene ved forskningen er unnagjort. Tvert imot er det viktig å være oppmerksom på dette gjennom hele forskningsprosessen, for det er ofte først når man kommer ut i feltet og skal gjennomføre selve forskningen, at de mer komplekse og gjerne uforutsigbare etiske problemstillingene oppstår.

Hensikten med dette kapittelet er å sette søkelys på slike problemstillinger. Inngangen er et forskningsprosjekt der video ble brukt for å utvikle kunnskap om undervisningspraksis i samiskopplæringen. Dette er et smalt felt og et lite miljø med få aktører, som i tillegg er mangfoldig. En slik liten forskningskontekst gjorde derfor etiske problemstillinger spesielt aktuelle, og det var fra begynnelsen av klart at det måtte tas særlige hensyn i forhold til både rekruttering, anonymisering og avklaring av egen forskerrolle. I dette kapittelet vil jeg drøfte de vurderingene som ble gjort i prosjektet for å sikre en etisk ansvarlig datainnsamling. Jeg tar utgangspunkt i to perspekter, forskerperspektivet og deltakerpersektivet, og vil ta for meg forskerrolle, samtykke og konfidensialitet. Jeg vil gjennomgående vise til de fagspesifikke forskningsetiske retningslinjene for samfunnsvitenskap, humaniora, juss og teologi (NESH, 2018). Jeg vil også trekke frem sentrale aspekter ved urfolksmetodologien. ${ }^{1}$ Kunnskap og bevissthet om forskning i et urfolksperspektiv kan føre til en mer etisk forsvarlig forskningpraksis, uansett hvilket felt du forsker innen.

1 Jeg bruker her begrepet i entall, men det er vanlig å bruke flertallsformen og snakke om urfolksmetodologier (se for eksempel Virtanen et al., 2020, s. 19) 


\section{Forskning i en urfolkskontekst}

Forskning på samiske temaer er forskning i en urfolkskontekst. Det første man må være klar over, er at dette er en kontekst der forskning har en problematisk historie. Verden over har urfolk opplevd å bli behandlet som passive forskningsobjekter. Opp gjennom historien har forskere strømmet til urfolkssamfunn for å samle data, bare for å forsvinne med den kunnskapen de innhentet (Kuokkanen, 2008, s. 48). Linda Tuhiwai Smith hevder at selve ordet forskning har et negativt fortegn for urfolk: «'Research' is probably one of the dirtiest words in the indigenous world's vocabulary» (Smith, 2012, s. 1). Dette forklarer hun med at forskning er så tett forbundet med imperialisme, kolonialisme og eksploatisme. Smith skriver fra sitt ståsted som maori i Aotearoa/ New Zealand, men forskninghistoriens mørke sider kjenner vi også til her i Sápmi/Sábme/Saemie, i Norge. I raseforskningens tid på 1900tallet, for eksempel, tok forskere mål av hodeskallene til samer, og samiske graver ble åpnet for å grave opp og hente ut samisk skjellmateriale (Niemi \& Semb, 2009). Alt i forskningens navn. Målet var å klassifisere samene som en mindreverdig rase. «Gjennom å definere koloniserte, underprivilegerte og marginaliserte folk som primitive og mindreverdige, sammenlignet med de herskende europeere, bidro vitenskapen tilå rettferdiggjøre erobring og undertrykkelse» (Schanche, 2002, s. 124). Realiteten i dag er heldigvis stort sett en annen, og urfolk har selv tatt eierskap til forskningen.

I dag er urfolksstudier et eget felt, og urfolksforskning, teorier og metodologier har fått plass i akademia (Virtanen et al., 2021, s. 12). Når det kommer til forskningsetikk, er det ifølge Olsen (2016, s. 28) spesielt to perspektiver som er viktige: På den ene siden omhandler det en mer overordnet tilnærming til forskningsetikk, sett i sammenheng med andregjøring og kolonialiserende aspekter ved forskning. Her står dekolonisering sentralt, noe som innebærer en kritisk tilnærming til forskningens grunnlag og tilnærmingsmåter for å undersøke hvordan, og hvis, den er preget av kolonialiserende fordommer (Olsen, 2016, s. 29). Utviklingen av egne urfolksmetodologier er en følge av dekolonisering, og det handler om å sette urfolks egne perspektiver og behov i førersetet: 
«The main aim of indigenous methodologies is to ensure that research on indigenous issues can be carried out in a more respectful, ethical, correct, symphatethic, useful and beneficial fashion, seen from the point of view of indigenous peoples» (Porsanger, 2004, s. 107-108). Etiske retningslinjer og regulering av forskning i urfolkssammeheng er det andre perspektivet som er viktig å nevne (Olsen, 2016). Dette er det ulik praksis på fra land til land. I New Zealand, Australia og Canada har de egne etiske retningslinjer for urfolksforskning (Drugge, 2016, s. 9). Dette er ikke tilfellet i Norge, men det har vært et tema også i samisk sammenheng (Kuokkanen, 2008; Møllersen et al., 2016; Porsanger, 2008; Stordahl et al., 2015). Enn så lenge er det imidlertid de nasjonale forskningsetiske retningslinjene vi har å forholde oss til her til lands, og disse sier ikke noe spesifikt om forskning i en urfolkskontekst. Det eneste relaterbare er bestemmelsen om at opplysninger om etnisk opprinnelse inngår som særlige kategorier av personopplysninger, og derfor må behandles spesielt forsiktig (Datatilsynet, 2019). Videre er det noen prinsipper som omhandler kulturforståelse:

Forskningsetiske retningslinjer for samfunnsvitenskap, humaniora, juss og teologi

\section{Ansvaret for å informere}

Forskeren skal gi forskningsdeltakerne tilstrekkelig informasjon om forskningsfeltet, forskningens formål, hvem som har finansiert prosjektet, hvem som får tilgang til informasjonen, hvordan resultatene er tenkt brukt, og om følgene av å delta i forskningsprosjektet.

[...]

Informasjonen må være tilpasset deltakernes kulturelle bakgrunn og formidles på et språk som de forstår.

16. Hensynet til andres verdier og handlingsmotiver [...] Forskeren skal vise respekt for verdier og holdninger hos forskningsdeltakerne, ikke minst når disse avviker fra det som er mest vanlig i storsamfunnet. 


\section{Forskning $i$ andre kulturer}

Forskning $i$ andre kulturer stiller spesielle krav til dialog med representanter for den kulturen som studeres.

Ved forskning i andre kulturer er det viktig med kunnskap om lokale tradisjoner, tradisjonell kunnskap og sosiale forhold. Forskeren bør i størst mulig grad være i dialog med lokalbefolkningen, representanter for den aktuelle kulturen og lokale myndigheter.

Urfolksmetodologien handler om å kritisk overveie kultursensitivitet, kulturell sedvane og respektfulle måter å drive forskning på (Virtanen et al., 2021, s. 18). Sentrale aspekter som går igjen i diskusjoner om etikk i urfolksforskning omhandler samtykke, deltakelse og eierskap til kunnskap: Samtykke må tilpasses den spesifikke urfolkskonteksten, urfolk må være forskningspartnere eller deltakere i stedet for passive forskningsobjekter, forskningen skal gi noe tilbake og komme urfolkssamfunnet til nytte, og i tillegg bør prosjekter godkjennes av egne forskningsetiske organer (Porsanger, 2008, s. 29). Kuokkanen (2008, s. 50) trekker også frem fritt, informert forhåndssamtykke som hjørnesteinen i etisk forskning. Viktig er det også at det er urfolkssamfunnenes egne behov som er utgangspunktet for forskningsprosjekter (Kovach, 2009, s. 149).

Mye av dette kjenner vi igjen fra de forskningsetiske retningslinjene. På den ene siden skulle det ikke være nødvendig å stille andre krav til forskning på samisk tematikk, hevder Bull (2002, s. 18), men påpeker samtidig at forskningsetikk nødvendigvis må forstås som noe situert og kontekstuelt. Kunnskap om det aktuelle samfunnet du skal inn i er derfor viktig, og innsikt i historie, tradisjoner, språk og kultur er klare forutsetninger for å kunne vurdere forskningsetiske problemstillinger i henhold til forskning på samiskrelaterte tema (Bull, 2002, s. 18). Kunnskap om sentrale aspekter ved urfolksmetodologien kan derfor være en måte å sikre en etisk forsvarlig forskningspraksis, siden det er en grunnleggende etisk måte å drive forskning på. Ifølge Smith (2012, s. 10) bør man alltid spørre seg: Hvem sin forskning er det snakk om? Hvem eier den? Hvem sine interesser ivaretar den? Hvem vil dra fordeler av den? Hvem 
har utarbeidet spørsmålene og definert rammene for studien? Hvem vil gjennomføre den? Hvem vil rapportere den? Hvordan vil resultatene formidles? Og så bør man handle deretter.

\section{Forskerperspektivet}

Forskningsetiske retningslinjer for samfunnsvitenskap, humaniora, juss og teologi (forts,)

18. Ansvaret for å fremtre med klarhet

Forskeren har et ansvar for å klargjøre begrensninger, forventninger og krav som følger med rollen som forsker, overfor forskningsdeltakerne.

Forskeren har ansvar for å tydeliggjøre grensene for forskningsrelasjonen i situasjoner hvor forskeren opptrer med flere roller overfor sine informanter.

I urfolksmetodologien er dette med forskerrolle og posisjonering viktig. «An obvious observation both from doing research on Indigenous issues and from reading literature on Indigenous methodology is that your position matters - and can limit you» (Olsen, 2016, s. 32). Og slik er det strengt tatt innenfor all forskning. Det er viktig å være bevisst sin egen forskerrolle. Kjønn, etnisitet, alder og erfaring er eksempler på faktorer som påvirker forskerens posisjonering og forforståelse (Gelir, 2021, s. 226). En forsker innehar gjerne en form for utsiderolle eller en innsiderolle. Det som utgjør insiderelasjonen varierer, og kan være tilhørighet til institusjonen det forskes på, å høre til en gruppe eller et miljø, eller bare å dele erfaringer, verdier eller engasjement (Dhillon \& Thomas, 2019, s. 444). Disse to forskerrollene kan oppfattes som motsatser til hverandre, hvor utsiderollen gjerne blir sett på som distansert og objektiv, og innsiderollen kulturelt forankret og subjektiv (Mcness et al., 2015, s. 295). Denne dikotomien er imidlertid for enkel, og det virker å være stor enighet om at man i praksis sjeldent kategorisk er enten-eller, men som regel er et sted midt imellom (Breen, 2009; Dhillon \& Thomas, 2019; Dwyer, 2009; Gelir, 2021; Mcness et al., 2015; Toy-Cronin, 2018). 
I urfolksmetodologien er innside-/utsidespørsmålet tett sammenvevd med det å være urfolk eller ikke, forklarer Olsen (2016, s. 33), og peker på man i litteraturen fort får en forståelse av at det gjøres et skarpt skille mellom såkalt «vestlig» forskning på den ene siden og urfolksforskning på den andre. Ved første øyekast virker det å være betydningsfult at det er urfolk selv som utfører forskningen (se f.eks. Chilisa, 2012; Kovach, 2009; Kuokkanen, 2008; Smith, 2012; Wilson, 2008). Kjernen i dekolonisering er tross alt at urfolk selv har tatt eierskap til forskningen, og at de ikke lenger er passive forskningsobjekter som blir forsket på, men at forskning nå skjer både av og med urfolk. Bildet er imidlertid ikke så svart-hvitt som man først får inntrykk av når det kommer til spørsmålet om forskerposisjon. Det er ikke nødvendigvis slik at urfolksbakgrunn automatisk generer tillit (Kovach, 2009, s. 147). Det finnes tross alt et bredt spekter av innsideperspektiver også innenfor urfolkssamfunn (Porsanger, 2004, s. 109). Ifølge Smith (2012, s. 140) er forskerrollen utfordrende uansett hvilken posisjon du har - helt klart problematisk som utside- og ikkeurfolksforsker, men også som innsideforsker. Det er nemlig ikke slik at bare du er en del av et samfunn eller miljø, så «vet du» eller «skjønner du» automatisk hva det er snakk om, påpeker hun. Det vil tvert imot være arrogant for forskere å anta at ens egen urfolksstatus og egne erfaringer er alt som telles (Smith, 2010, s. 140).

Innsideforskeren må konstant være refleksiv og fortløpende kritisk vurdere egne prosesser, relasjoner og forskningskvalitet (Smith, 2012, s. 139). Dette må utsideforskere også gjøre, påpeker Smith (2012, s. 139), men den vesentlige forskjellen er at innsideforskeren har en grupperolle å gå tilbake til, og som også skal ivaretas. Ifølge Toy-Cronin (2018, s. 457) er en av utfordringene ved innsideforskning nettopp rollekonflikten som oppstår når du står i forskerrollen og innsiderollen samtidig. Tillit og tilgang er gjerne fordeler som følger en innsiderolle, men håndtering av eksisterende relasjoner, og balansering av grupperollen og den nye forskerrollen, er en utfordring som ofte kommer uventet på innsideforskere (Toy-Cronin, 2018, s. 465). På den ene siden kan nærhet føre til et nivå av aksept og åpenhet som kanskje ikke hadde vært mulig uten, men samtidig er faren ved å ha nære relasjoner med deltakerne at ting ikke blir forklart ordentlig, da det ofte bare antas at forskeren forstår det 
deltakerne mener (Dwyer, 2009, s. 58). I tillegg må forskeren være bevisst på å skille mellom egne erfaringer og antakelser og deltakerens perspektiver, slik at ikke det en har til felles vektlegges i analysen (Dwyer, 20093, s. 58$)$.

\section{Deltakerperspektivet}

Forskningsetiske retningslinjer for samfunnsvitenskap, humaniora, juss og teologi (forts.)

\section{Samtykke og informasjonsplikt}

Når forskningen omhandler personopplysninger, må forskeren både informere og innhente samtykke fra dem som deltar i forskningen eller er gjenstand for forskning. Samtykket må være fritt, informert og uttrykkelig.

[...] At samtykket er fritt, betyr at det er avgitt uten ytre press eller begrensninger av personlig handlefrihet. Slikt press kan komme av forskerens eget nærvær, eller via autoritetspersoner forskeren har vært i kontakt med.

[...] At samtykket er informert, betyr at forskeren har gitt tilstrekkelig informasjon om hva det innebærer å delta i forskningsprosjektet. Behover for forståelig informasjon er spesielt stort når forskningen innebærer risiko for belastninger. [...] At samtykket er uttrykkelig, betyr at deltakerne klart og tydelig gir uttrykk for at de er innforstått med hva det faktisk innebærer å delta i forskningsprosjekt. De skal ha reelle muligheter til å avstå fra å delta uten at det medfører ulemper, og de skal være innforstått med at de til enhver tid har rett til å avbryte sin deltakelse uten at dette får negative konsekvenser.

Rollekonflikten som oppstår for innsideforskeren kan gjøre seg spesielt gjeldende når det kommer til samtykke. Hvis deltakerne først og fremst oppfatter forskeren til å være i grupperollen, kan det føre til at det oppleves vanskeligere å takke nei til deltakelse (Toy-Cronin, 2018, s. 461). Spesielt gjelder dette i tilfeller med tydelige maktstruktuer, som for eksempel forskning som gjennomføres på eget arbeidssted, der forskeren som til vanlig er i lederstilling eller høyere opp i makthierarkiet, ønsker 
å rekruttere ansatte til forskningen. Det kan oppleves vanskelig å skille mellom forsker- og grupperollen, og det kan gjøre det vanskelig for kollegaene å si nei (Toy-Cronin, 2018, s. 461). Utfordringen ligger dermed i å skille de to rollene, slik at potensielle deltakere føler at det er greit å avslå deltakelse, hvis de helst ønsker det.

Yakura (2005, s. 148) setter spørsmåltegn ved om deltakere, tross et informert samtykke om å delta i videoforskning, likevel er klar over hva det innebærer å bli filmet i en forskningskontekst. Hun eksemplifiserer med egen forskning der hun tok videopptak av klasseromsinteraksjoner. Hun opplevde at de fleste av elevene var komfortable med å bli filmet. Flere var også vant med dette fra private sammenhenger, som for eksempel hjemmevideoer. Dette var i 2005, og det er nok rimelig å anta at det er enda mer gjeldende i dag, hvor sosiale medier og smarttelefoner har gjort det enda mer vanlig å filme og ta bilder i hverdagen. Yakura (2005, s. 148) erfarte likevel at enkelte elever ikke var komfortable med filmingen, når de først kom i gang. En av elevene begrunnet dette med at hen ble så selvbevisst. Kameraeffekten er gjerne det mange peker på som den store ulempen med videoforskning; man ønsker å studere naturlige interaksjoner, men ved å sette opp videokameraer og å be om samtykke fra deltakere, så forstyrrer vi denne naturlige settingen (Blikstad-Balas, 2017). Blikstad-Balas (2017, s. 513) hevder imidlertid at denne effekten er overdrevet, og at reaktivitet ikke er den største ulempen ved å bruke video til datainnsamling. Hun viser til at alle metoder i større eller mindre grad vil påvirke den situasjonen som man ønsker å portrettere, det være seg en intervjusituasjon eller observasjon uten kamera. Hun viser til flere forskningsprosjekter der kameraet sjeldent har vist seg å være et forstyrrende element i lengden (se eksempelvis Blikstad-Balas, 2012; Sørvik et al., 2015). Når deltakerne ble spurt om det, svarte de at de ofte glemte av hele kameraet. Dette opplevde Aarsand og Forsberg (2010) i sin studie der de filmet i hjemmene til folk og erfarte at deltakerne etter hvert ble vant til kameraene, også i en slik privat setting. Deres erfaringer var at det imidlertid var enkelte situasjoner deltakerne ikke ønsket å ta opp på film, som regel knyttet til intimitet og følelser. Alder var også en faktor, der spesielt eldre barn var tydelige med å markere når filming var uønsket. Barley og Bath (2013, s. 1) bruker begrepet familiarisation, som på norsk 
blir å bli kjent med eller å bli fortrolig med, og argumenterer med at det spesielt i forskning med barn er viktig med en bli kjent-periode, slik at barna kan bli vant til forskeren. Dette gjør at deltakere får tid til å bli vant til forskere og føler mer kontroll over situasjonen, slik at de kan fatte en informert beslutning om å samtykke.

Forskningsetiske retningslinjer for samfunnsvitenskap, humaniora, juss og teologi (forts.)

\section{Konfidensialitet}

Forskeren skal som hovedregel behandle innsamlet informasjon om personlige forhold konfidensielt og fortrolig. Personlige opplysninger skal vanligvis være avidentifisert, mens publisering og formidling av forskningsmaterialet vanligvis skal være anonymisert.

Ivaretakelse av konfidensialitet er en sentral utfordring ved innsideforskning, og spesielt når forskningen finner sted i et mindre miljø eller samfunn (Toy-Cronin, 2018, s. 461). Vanlig praksis, som bruk av pseudonymer og anonymisering av stedet for datainnsamlingen, vil ikke nødvendigvis fungere like godt. Det kan gi begrenset effekt i innsideforskning, da det som regel ikke vil være vanskelig å identifisere institusjonen, gruppen eller samfunnet, når forskningen blir kjent (Toy-Cronin, 2018, s. 461). Hvordan kan man da sikre deltakernes konfidensialitet? Et alternativ er å beskrive dataene veldig overordnet og uten detaljer som kan bidra til identifisering. Dilemmaet med altfor vage beskrivelser er imidlertid at det ikke lenger er en relevant, korrekt gjengivelse av hendelsene, og dermed kanskje heller ikke interessant for leseren (Toy-Cronin, 2018, s. 463). Toy-Cronin (2018, s. 463) forslår at et alternativ kan være å konstruere en case der detaljer er hentet fra ulike caser, slik at det på den måten blir vanskelig å identifisere enkeltdeltakeres utsagn. Når det kommer til videodata kan man begrense tilgangen til hvem som kan se videomaterialet (Derry et al., 2010, s. 36). Jeg viser også til kapittelet av Trine Telnes som omhandler ulike måter å transkribere videodata på. 
Ifølge urfolksmetodologien er det ikke gitt at konfidensialitet er det etiske riktige å søke etter: Kovach (2009, s. 148) er kritisk til de etiske komiteene som pålegger konfidensialitet. Hun mener anonymisering burde være valgfritt i tilfeller med liten risiko: «It matters because our stories are our truth and knowledge. It is about standing behind one's words and recognizing collective protocol, that one is accountable for one's words» (Kovach, 2009, s. 148).

\section{Etiske vurderinger i eget prosjekt}

Som nevnt innledningsvis vil eksemplifiseringen av etiske utfordringer i en urfolkskontekst komme fra et prosjekt som undersøker samiskopplæring for elever i grunnopplæringen. I dette prosjektet gjorde vi videoobservasjoner av ulike undervisningsaktiviteter, med mål om å finne ut av hvordan videodata kan benyttes som verktøy for dokumentasjon av læringskontekster. Det var et forprosjekt med formål om å utvikle et forskningsmessig grunnlag for et hovedprosjekt om implementeringen av de nye læreplanene i samiskfagene i skolen. For å utvikle kunnskap om hva det er viktig å sette søkelys på i en større forskningssatsning, ønsket vi å undersøke ønskene og behovene til skoler som driver med samiskopplæring. Det ble gjort intervjuer av både lærere og skoleledere for å undersøke hvilke muligheter og utfordringer som finnes i den samiske skolehverdagen i dag.

Det ble tidlig klart at deler av datainnsamlingen potensielt ville foregå i mitt eget nærsamfunn. På den ene siden kunne dette fungere som en døråpner og gi lettere tilgang, men på den andre siden fryktet jeg at at en nær relasjon til aktuelle deltakere ville kunne fungere som et uheldig ytre press. Det var to grunner til at jeg fryktet at dette kunne forekomme. For det første at de grunnet vår relasjon ville være mer tilbøyelig til å takke ja til en deltakelse de kanskje egentlig ikke hadde overskudd eller lyst til å være med på. Jeg var bekymret for at rolleblandingen min ville kunne føre til at de ville være mer villig til å delta i videoforsking enn de ville vært hvis noen utenfra spurte dem. Den andre grunnen bunnet i at ressursgrunnlaget er så lite. De samiske språksamfunnene er små, og de mulige deltakerne er få. Jeg fryktet at dette kunne føre til at samtykke 
ble gitt på grunn av en pliktfølelse overfor det samiske. Det ble derfor viktig å balansere dette med å aktivt rekruttere, uten å utøve press. Vi tok først kontakt med skolelederne, som videreformidlet forespørselen til lærerne sine.

Når skolene og lærerne hadde takket ja til å delta, gjensto samtykke fra elevene. De eldste som deltok var over 15 år, og kunne derfor samtykke selv. For de yngste ble det innhentet tillatelse fra foresatte. Vi opplevde en forskjell mellom de yngste og de eldre elevene. De yngste barna gikk på mellomtrinnet og virket ikke å ha problemer med filmingen. Hvis noe, så var de nysgjerrige på kameraet og filmingen. Vi brukte både GoProkameraer og et større kamera med stativ. GoPro-kameraet ble festet til bordene når elevene hadde gruppearbeid og mer formell undervisning, mens vi brukte det større kameraet for å filme andre, praktiske aktiviteter. Elevene virket stort sett ikke å legge merke til kameraet, men etter omtrent en halv dag med filming av ulike læringskontekster, så en av elevene direkte inn i kameraet og på meg, og spurte hvorfor vi egentlig filmet. Vi hadde i forkant presentert oss og forklart, også til elevene, hvorfor vi var der, og at vi ønsket å filme dem for å lære om hvordan samiskundervisningen fungerer. Jeg gjentok dette, og eleven fikk se på kameraet og hva det filmet.

De eldste elevene virket mer usikre på dette med filming, eller i det hele tatt til at det kom noen fremmede inn i klasserommet. Det kan ha å gjøre med at de var få elever, og det ble mange voksenpersoner i rommet når vi kom. Vi ankom skolen på morgenen, i et friminutt, etter at de var kommet i gang med dagen. Vi hilste og satte oss ned i klasserommet før lærerne forsatte undervisningsøkten, og først etter en stund introduserte lærerne oss. Dette var bevisst fra deres side, ble det senere forklart, slik at elevene skulle bli vant til oss før vi ble introdusert som forskere og at vi ønsket å filme. Vi fortalte selv nærmere om prosjektet og hvorfor vi ønsket å filme. Jeg snakket samisk der det var naturlig, og hadde også tatt på meg samiskinspirerte klær. Det gjorde jeg bevisst med tanke på at klær kan fungere som identitetsmarkører, og at de derfor med en gang ville skjønne at jeg var samisk selv. Vi presenterte oss og spurte om det var greit om vi gjorde videopptak. Noen av elevene sa ganske fort ja, etter å ha spurt om hva vi skulle bruke det til. Andre virket imidlertid mer usikre, og i det hele tatt 
mer sjenerte av seg. Vi ble enige om at de skulle snakke om dette over lunsjen, uten at vi var til stede. På denne måten fikk elevene mulighet til å komme med innsigelser, uten at de måtte si det direkte til oss. Vi fikk imidlertid lov til å filme, men vi ble enige om å sette kameraene bakerst i klasserommet, slik at ikke elevene ville vises så godt. Når undervisningen gikk over til å inkludere mer praktiske aktiviteter som involverte mer bevegelse, og der elevene arbeidet mer selvstendig, slo vi av kameraene. Dette for at elevene ikke skulle føle at det var skummelt å bevege seg bort fra plassen sin. Vi valgte i dette tilfellet å bare bruke GoPro-kameraer som vi satte opp bakerst i klasserommet for at de skulle være minst mulig forstyrrende. En mikrofon ble satt midt i klasserommet, og en mygg ble montert på læreren, for å sikre god nok kvalitet på lydopptakene.

I dette prosjektet vil videodataene bare bli brukt til å utforske ulike undervisningskontekster forskningsmessig, og transkriberingen av videomaterialet vil bli anonymisert etter gjeldende normer og regler.

\section{Videoforskning i et lite miljø}

I dette kapittelet har jeg trukket frem etiske aspekter som kan gjøre seg spesielt gjeldende ved bruk av video i en liten forskningskontekst. Etiske problemstillinger blir ofte satt på spissen i et slikt forskningsfelt. I vårt prosjekt var det vurdering av egen forskerrolle, og etiske prinsipper som konfidensialitet og samtykke som sto sentralt.

Når det kommer til forskerrolle gjorde vi først en vurdering av hvorvidt det at jeg selv er samisk, ville gi meg en innsiderolle. Fordeler forbundet med innsiderollen er tilgang, aksept og tillit (Toy-Cronin, 2018). Av urfolksmetodologien får man videre en forståelse av at det er viktig at urfolk selv gjennomfører forskning som omhandler urfolk (Smith, 2012). På den ene siden kan det være at min samiske bakgrunn bidro til en grunnleggende aksept og tillit. Jeg prøvde å bruke samisk der det var naturlig, og hadde også tatt på meg klær som kunne signalisere at jeg selv var samisk. Kunnskap om samisk kultur, språk, historie og tradisjoner er viktig i forskning innenfor forskning på samisk tematikk (Bull, 2002), og det er nok lettere å stole på at samer selv har denne innsikten. Samtidig bør man være klar over at de samiske samfunnene er like mangfoldige og 
varierte som andre samfunn, og det er ikke gitt at den samiske kulturen jeg selv har vokst opp med, er noe deltakere fra andre steder kjenner seg like godt igjen i. Når Bull (2002) påpeker at forskningsetikk må forstås som noe situert og kontekstuelt, bør derfor også samiske forskere ta dette innover seg. Med Smiths (2012) ord ville det vært arrogant av meg å anta en innsidestatus i et miljø jeg ikke kjenner så godt til. Kulturforståelse må ikke forveksles med innsidekunnskap.

Det ble tidlig klart at deler av datainnsamlingen muligens ville skje i eget samfunn, og at jeg derfor ville kunne møte flere av utfordringene forbundet med innsideforskning. De forskningsetiske retningslinjene understreker forskerens ansvar om å klargjøre hva forskerrollen innebærer av begrensninger og forventninger, og at en må påse å være ekstra tydelig spesielt i de tilfeller der forskeren har flere roller overfor deltakerne (NESH, 2018). Det at man innehar en dobbelrolle, både en grupperolle og forskerrolle, kan skape rollekonflikter som kan oppleves utfordrende for forskeren (Toy-Cronin, 2018). Det erfarte jeg i dette prosjektet. Mens jeg på den ene siden så på innsiderollen som fordelaktig, siden det kunne føre til lettere tilgang til forskningsfeltet, opplevde jeg på den andre siden at den påla meg et desto større ansvar til å påse at jeg ikke utøvet press til deltakelse. Jeg var bekymret for at deltakere, på grunn av sin relasjon til meg, ville gi mer av seg selv enn de ellers ville ha gjort. Det ble derfor viktig å balansere rekruttering til prosjektet uten å utøve press. I prosjektet vårt tok vi derfor først kontakt med rektor, som formidlet forespørselen til lærerne sine. Selv om det hadde vært enklere for meg å gå direkte til mulige deltakere siden jeg kjenner dem fra før, valgte vi å gjøre det slik for å unngå rolleblanding.

Videre var bekymringen at press kunne forekomme grunnet en ansvarsfølelse for det samiske. De som ble forespurt til å delta vet jo også at de er blant de få som kan delta i slike prosjekter. Vi fryktet at dette kunne oppleves som at de derfor «måtte» eller «burde» gjøre det. Kunnskap om samiskopplæring og de nye læreplanene er viktig for at man skal kunne nå gjennom på nasjonalt nivå med krav om eksempelvis tilrettelegging, kompetanseutvikling og læremiddelutvikling, og dette kan føre til at lærere og andre i den samiske skolen føler at de bør bidra. De forskningsetiske retningslinjene angir at informasjon om prosjektet 
skal gis på en nøytral måte, nettopp for å unngå at deltakerne opplever urimelig press (NESH, 2018). Vi var derfor opptatte av å å balansere dette med å på den ene siden informere om prosjektets relevanse og viktighet, og på den andre siden ikke være for påståelige, slik at de ikke takket ja til noe de egentlig ikke hadde tid og overskudd til. Det at dette i det hele tatt var en problemstilling kan fortone seg merkelig i et urfolksmetodologisk perspektiv. Et grunnleggende prinsipp i urfolksmetodologien er at forskningsprosjekter bør være forankret i lokalsamfunnet og bunne ut i behovene urfolket selv definerer (Kovach, 2009, s. 160). I et slikt perspektiv er det etisk problematisk at noen utenfra kommer med ferdigdefinerte forskningsbehov. Dette er imidlertid et forprosjekt som tar sikte på å utvikle et hovedprosjekt, og et av delmålene med forprosjektet er nettopp å forankre det hos sentrale aktører, samt å utvikle hovedprosjektet i henhold til behovene og ønskene til den samiske skolen. Vi vil ta resultetene fra dette forprosjektet tilbake til skolene for å diskutere og finne frem til hva det bør settes søkelys på i et fremtidig hovedprosjekt.

En annen side ved samtykke er hvorvidt deltakerne forstår hva deltakelse $\mathrm{i}$ et forskningsprosjekt innebærer (Yakura, 2005). De forskningsetiske retningslinjene er tydelige på forskerens ansvar i henhold til dette. Forskeren skal ikke bare innhente samtykke, men samtykket skal være informert og uttrykkelig, noe som innebærer at deltakerne skal ha fått tilstrekkelig informasjon om prosjektet, inkludert formål, metode og mulige konsekvenser, og de skal ha gitt tydelig utrykk for at de forstår hva deltakelse faktisk innebærer (NESH, 2018). Yakura (2005) hevder at dette er spesielt viktig i videoforskning, da deltakere ofte ikke innser at det er ubehagelig, før de er inne i selve filmingssituasjonen. Både BlikstadBalas (2017) og Aarsand og Forsberg (2010) erfarte imidlertid at deltakerne etter hvert ble vante med kameraet og ikke lot til å legge merke til dem. Aarsand og Forsberg (2010) erfarte i tillegg at spesielt eldre barn var mer restriktive mot filmingen og var tydelige på når de ikke ønsket å bli filmet. I vårt prosjektet erfarte vi også en forskjell mellom de yngste og eldste elevene, der de yngste ikke virket å være så opptatte av kameraet. De eldre elevene var derimot mer tilbakeholdne. Dette ble forbilledlig løst av lærerne, som hadde lagt opp til at elevene først skulle få en mulighet til å bli vant til fremmede i rommet, før de introduserte oss og fortalte 
om at vi ønsket å bruke videokamera. Elevene fikk drøfte eventuell deltakelse i fellesskap, uten forskerne til stede, noe som nok var viktig som et grunnlag for at de aksepterte filmingen. Barley og Bath (2013) påpeker at i forskning med barn er det ofte er viktig og fordelaktig at de får tid til å bli kjent med forskerne. På den måten får de et bedre grunnlag for å ta en informert beslutning om deltakelse eller ikke.

I dette prosjektet erfarte vi at de nasjonale forskningsetiske retningslinjene for samfunnsvitenskap, humaniora, juss og teologi utgjorde et godt utgangspunkt for en etisk ansvarlig forskningspraksis, også innenfor videoforskning. Urfolksmetodologiske tilnærminger gav oss i tillegg flere strenger å spille på. Urfolksmetodologien betegner en grunnleggende etisk måte å drive forskning på, og handler dypest sett om ansvarlighet og respekt for de menneskene og samfunnene som involveres i din forskning.

\section{Referanser}

Barley, R. \& Bath, C. (2013). The importance of familiarisation when doing research with young children. Ethnography and Education, 9(2), 182-195. https://doi.org/ 10.1080/17457823.2013.841552

Blikstad-Balas, M. (2017). Key challenges of using video when investigating social practices in education: Contextualization, magnification, and representation. International Journal of Research \& Method in Education, 40(5), 511-523. https://doi.org/10.1080/1743727X.2016.1181162

Blikstad-Balas, M. (2012). Digital literacy in upper secondary school - what do students use their laptops for during teacher instruction? Nordic Journal of Digital Literacy, 7(2), 81-96.

Breen, L. (2007). The researcher «in the middle»: Negotiating the insider-outsider dichotomy. The Australian Community Pscychologist, 19(1), 163-174.

Bull, T. (2002). Kunnskapspolitikk, forskningsetikk og det samiske samfunnet. Samisk forskning og forskningetikk. Forskningsetiske komiteer.

Chilisa, B. (2012). Indigenous research methodologies. Sage.

Datatilsynet. (2019, 8. august). Spesielt om sarlige kategorier av personopplysninger (sensitive personopplysninger) - forbud og unntak. https://www.datatilsynet.no/ rettigheter-og-plikter/virksomhetenes-plikter/behandlingsgrunnlag/veilederom-behandlingsgrunnlag/spesielt-om-sarlige-kategorier-av-personopplysningersensitive-personopplysninger-og-unntak/ 
Derry, S. J., Pea, R. D., Barron, B., Engle, R. A., Erickson, F., Goldman, R., Hall, R., Koschmann, T., Lemke, J. L., Sherin, M. G. \& Sherin, B. L. (2010). Conducting video research in the learning sciences: Guidance on selection, analysis, technology, and ethics. Journal of the Learning Sciences, 19(1), 3-53. http://dx.doi. org/10.1080/10508400903452884

Dhillion, J. K. \& Thomas, N. (2019). Ethics of engagement and insider-outsider perspectives: Issues and dilemmas in cross-cultural interpretation. International Journal of Research and Method in Education, 42(4), 442-453. https://doi.org/ 10.1080/1743727X.2018.1533939

Drugge, A.-L. (2016). Introduction. I A.-L. Drugge (Red.), Ethics in Indigenous research. Past experiences - future challenges (s. 9-18). Centre for Sami Research.

Dwyer S. C. \& Buckle J. L. (2009). The space between: On being an insider-outsider in qualitative research. International Journal of Qualitative Methods, 8(1), 54-63. https://doi.org/10.1177\%2F160940690900800105

Gelir, I. (2021). Can insider be outsider? Doing an ethnographic research in a familiar setting. Ethnography and Education, 16(2), 226-242. https://doi.org/ $10.1080 / 17457823.2021 .1905535$

Kovach, M. (2009). Indigenous methodologies. Characteristics, conversations, and contexts. University of Toronto Press.

Kuokkanen, R. (2008). From research as colonialism to reclaiming autonomy: Toward a research ethics framework in Sápmi. Ethics in Sámi and Indigenous research (Raporta/Report 1/2008). Sami Instituhtta Sámi allaskuvla.

McNess, E., Arthur, L. \& Crossley, M. (2015). 'Ethnographic dazzle' and the construction of the 'other': Revisiting dimensions of insider and outsider research for international and comparative education. Compare: A Journal of Comparative and International Education, 45(2), 295-316. https://doi.org/10.1080/03057925.201 3.854616

Møllersen, S., Stordahl, V., Tørres, G. \& Eira-Åhren, I. M. (2016). Developing an adequate questionnaire addressing psychosocial distress in a reindeer herding population: Some lessons learned. I A.-L. Drugge (Red.), Ethics in Indigenous research. Past experiences - future challenges (s. 175-198). Centre for Sami Research.

NESH. (2018, 04. desember). Forskningsetiske retningslinjer for samfunnsvitenskap, humaniora, juss og teologi. De forskningsetiske komiteene.https://www. forskningsetikk.no/retningslinjer/hum-sam/forskningsetiske-retningslinjer-forsamfunnsvitenskap-humaniora-juss-og-teologi/

Niemi, E. \& Semb, J. (2009, 11.02). Forskningsetisk kontekst: Historisk urett og forskning som overgrep. De forskningsetiske komiteene. https://www. forskningsetikk.no/ressurser/fbib/bestemte-grupper/historisk-urett-ogforskning-som-overgrep/ 
Olsen, T. (2016). Responsibility, reciprocity and respect. On the ethics of (self-) representation and advocacy in Indigenous studies. I A.-L. Drugge (Red.), Ethics in Indigenous research. Past experiences - future challenges (s. 25-44). Centre for Sami Research.

Personsopplysningslova. (2018). Lov om behandling av personopplysninger (LOV-2018-0615-38). Lovdata. https://lovdata.no/lov/2018-06-15-38

Porsanger, J. (2004). An essay about Indigenous methodology, Nordlit, 15, 105-120. https://doi.org/10.7557/13.1910

Porsanger, J. (2008). Ethical conduct in research involving Indigenous peoples: General considerations. Ethics in Sámi and Indigenous research (Raporta/Report 1/2008). Sami Instituhtta Sámi allaskuvla.

Schanche, A. (2002). Knoklenes verdi: Om forskning på og forvaltning av skjelettmateriale fra samiske graver. Forskningsetiske komiteer.

Smith, L. T. (2012). Decolonizing methodologies. Research and Indigenous peoples (2. utg.). Zed Books.

Stordahl, V., Tørres, G., Møllersen, S. \& Eira-Åhren, I. (2015). Ethical guidelines for Sami research: The issue that disappeared from the Norwegian Sami Parliament's agenda? International Journal of Circumpolar Health, 74(1). https://doi.org/ 10.3402/ijch.v74.27024

Sørvik, G. O., Blikstad-Balas, M. \& Ødegaard, M. (2015). «Do books like these have authors?» New roles for text and new demands on students in integrated scienceliteracy instruction. Science Education, 99(1), 39-69. https://doi.org/10.1002/ sce.21143

Toy-Cronin, B. (2018). Ethical issues in insider-outsider research. I R. Iphofen \& M. Tolich (Red.), The Sage handbook of qualitative research ethics (s. 455-468). Sage. https://dx.doi.org/10.4135/9781526435446.n31

Virtanen, P. K., Olsen, T. \& Keskitalo, P. (2021). Contemporary Indigenous research within Sámi and global Indigenous studies contexts. I P. K. Virtanen, P. Keskitalo \& T. Olsen (Red.), Indigenous research methodologies in Sámi and global contexts (s. 7-32). Brill. https://doi.org/10.1163/9789004463097_oo2

Yakura, E. (2004). «Informed consent» and other ethical conundrums in videotaping interactions. I P. LeVine \& R. Scollon (Red.), Discourse and technology. Multimodal discourse analysis (s. 146-150). Georgetown University Press.

Wilson, S. (2008). Research is ceremony. Indigenous research methods. Fernwood Publishing.

Aarsand, P. \& Forsberg, L. (2010). Producing children's corporeal privacy: Ethnographic video recording as material-discursive practice. Qualitative Research, 10(2), 249-268. https://doi.org/10.1177/1468794109356744 


\title{
Visuelle vendinger i videoanalyse: Transkripsjon i møte med barnehagens marginaliserte og målbundne materialiteter
}

\section{Trine Telnes}

\author{
Fakultet for lærerutdanning, kunst- og kulturfag, Nord universitet
}

\begin{abstract}
This chapter is a methodological and ethical examination of the following research question: How does one transcribe and analyze the presence and practices of the kindergarten's youngest children, and other human and non-human actors, in a way that shows their agency and contributions? Video recording is a common method of data generation in social science research and poses the challenge of bringing the audiovisual data into academic texts. Traditionally, video recordings are transformed into pure textual representations called transcription. In particular, it is often the audible speech acts that inform the transcription and analysis, at the expense of the visuals in the video recordings. The embodied, experiential, aesthetic, material and multimodal can be difficult to present through written language alone. The significance of materiality, nonverbal behavior and bodily interaction is enhanced with one- and two-year-old children, whose expressions are often dominated by the nonverbal. Through examples from pedagogical video research in kindergarten, the author explores how different ways of transcribing and analyzing video can visualize the presence, interactions, and practices of the youngest children, the kindergarten teachers and other actors. A visual turn toward poetic video-transcription, multimodal transcription, and a hybrid between drawings and transcription the researcher has named 'cartoon transcription', helps to limit marginalization of the different actors and their multifaceted contributions. Breaking the hegemony of the word over the visual can make bodily, spatial, and material resources visible. A fusion of words and images can produce new forms of knowledge, contribute to a high epistemological standard and provide transparency.
\end{abstract}

Keywords: video analysis, visual research methods, comics-based research, cartoon transcription, poetic video transcription, kindergarten

Sitering: Telnes, T. (2021). Visuelle vendinger i videoanalyse: Transkripsjon i møte med barnehagens marginaliserte og målbundne materialiteter. I F. Rusk (Red.), Videoforskning på ulike loringsarenaer: Mangfoldig videodata i pedagogisk forskning og utvikling (Kap. 3, s. 55-78). Cappelen Damm Akademisk. https://doi.org/10.23865/noasp.153.ch3

Lisens: CC BY-NC-ND 4.0 


\section{Introduksjon}

Dette kapittelet er en etisk og metodologisk undersøkelse innenfor videoforskning i barnehagen, og den delen av forskningsprosessen som omhandler transkripsjon og analyse av videodata. For at barnehageforskere skal kunne skape etterrettelige forskningstekster, er det av betydning at også marginaliserte og målbundne materialiteter inkluderes i framstillingene. I dette kapittelet eksemplifiseres disse materialitetene med de aller yngste barna (1-2 år), en treplate og en håndsag. $\AA ̊$ omforme den visuelle og hørbare informasjonen i et filmklipp til en rettferdig og likeverdig (re)presentasjon av de yngste barna og de tause materialitetene, kan være utfordrende. Barnas handlinger og uttrykksmåter kan ha en så enorm detaljrikdom og kompleksitet ved seg, at det å skulle forvandle det til akademisk tekst kan oppleves som en umulighet. Selv om det har begynt å endre seg de siste tiårene, er fortsatt en del tradisjonelle transkripsjonsmetoder som brukes innenfor forskning både voksensentrerte, logosentriske ${ }^{1}$ og bygget opp rundt talespråk. Dette kan igjen bidra til å marginalisere andre former for eksistens enn de talende menneskenes, og annen kommunikasjon enn den verbale. Vi kan risikere at rom (Yanow, 2010), artefakter (Luff \& Heath, 2019), barn som enda ikke har utviklet talespråk (Johannesen, 2016) og andre annerledes-kommuniserende (Millet \& Estève, 2012) blir underrepresentert og utilsiktet diskriminert i forskningstekster. De kan bli usynliggjort. Dette kapittelet tar derfor for seg problemstillingen: Hvordan transkribere og analysere tilstedeverelsen og praksisene til barnehagens yngste barn, og andre menneskelige og ikke-menneskelige aktører, på en måte som viser deres agentskap og bidrag? Gjennom kapittelet viser jeg noen eksempler på hvordan dette kan løses, men anerkjenner samtidig at det finnes en rekke andre forskningsbidrag med metoder som også løser dette godt. Jeg vil nå forklare de sentrale begrepene marginalisering, transkripsjon og visuell vending.

Marginalisering er prosessen hvor ting, individer eller grupper gjøres marginale, altså mindre viktige eller ubetydelige. Ordet refererer til det å ekskluderes, ikke være i sentrum, å bli holdt utenfor meningsfull

Logosentrisme har ord, skrift- og talespråket i sentrum («Logosentrisme», 2021). 
deltagelse i samfunnet og utenfor makt eller innflytelse (Nordbø, 2018). De siste tiårene har barne- og barndomsforskningen, barnehagefeltet og samfunnet for øvrig, beveget seg mot å i større grad se små barn som subjekter med rettigheter og agentskap² (valentine, 2011). Det snakkes om et paradigmeskifte i synet på barn (Bae, 2007; James et al., 1998). Men i likhet med blant annet kvinner, homofile og funksjonshemmede, er barn fortsatt en marginalisert gruppe, og verdenssamfunnet har fortsatt en vei å gå mot å behandle dem som likeverdige mennesker (Bae, 2007). Det finnes belegg for å si at barn generelt, og de yngste barna spesielt, både blir ansett som mindre viktige i samfunnet, og at de holdes utenfor makt og innflytelse. Barn er en marginalisert gruppe i vårt voksensentrerte samfunn (Punch, 2002), de er en minoritet i samfunnet som opplever å ha lavere status enn voksne (Mayall, 2002), og bare det å vore barn kan i seg selv oppleves som stigmatiserende (James, 2007). Desto viktigere blir det at barns likeverd, agentskap og bidrag blir forsøkt tydeliggjort i videotranskripsjoner.

Transkripsjon er en viktig praksis innenfor videoforskning. Transdelen i ordet transkripsjon antyder en forflytning og forvandling fra ett uttrykk til et annet, ofte fra taleuttrykk til skriftuttrykk (Kress, 2011). I transkripsjonene finnes utvalgte deler av verden, som forskeren forsøker å fryse eller «holde i ro» for å analysere. I en skriftlig gjengivelse av en svært detaljert virkelighet må vi velge å løfte fram noe, på bekostning av andre detaljer. Dette er av hensyn til forskningsspørsmål, ressurser vi forskere har til rådighet, relevans for videre analyse, og lesbarhet. Som forsker er du med på å konstruere de transkripsjonene du lager gjennom de mange ulike valgene du tar, hva du velger å løfte fram som viktig, og på hvilken måte du rammer inn og får fram dette viktige (Bezemer \& Mavers, 2011). På den ene siden kan vi si at transkripsjon er en skapende prosess kreert av forskeren, men på den andre siden må transkripsjonen samtidig fange inn noe som faktisk eksisterer i virkeligheten uavhengig av forskeren og transkripsjonsprosessen (Hammersley, 2010). Bengt Kristensson Uggla

2 Agentskap, slik det brukes i denne teksten, bygger på forståelsene til blant andre valentine (2011) og Marchand (2018). Personer eller ting agerer, har agentskap og får ting til å skje uavhengig av intensjonalitet, rasjonalitet eller evne til artikulasjon. Handlekraft og agentskap ses som materielt, kroppslig og relasjonelt. 
(2019, s. 92) anser generering av empiri som en vekselvirkning mellom å oppdage og oppfinne verden. Med Alice Fulton ${ }^{3}$ (1990) og Karen Barads (2007) ord vil jeg beskrive dette som forsøk på å «møte universet på halvveien» - en transkripsjon er på en og samme tid skapt av både oss forskere og av det som faktisk skjer i den sanselige, visuelle verden som studeres.

Vendinger innen filosofi og vitenskap, slik som den visuelle vendingen, forutsetter at det oppstår en utvikling og viktig endring på tvers av flere disipliner (Boxenbaum et al., 2018). Betegnelsen visuell vending ${ }^{4}$ ble først gitt av William J. T. Mitchell (1995), som knytter dette til et observert skifte i filosofers oppmerksomhet mot visuell meningsskaping og representasjon. Den visuelle vendingens tenkning vektlegger verdens visuelle karakter, hvor forskere har en $ø$ kt interesse for visuell informasjon og visuelle forskningsmetoder. Jenni Karlsson (2012) omtaler disse som visuelle forskere, og sier at nøkkeltrekket ved visuelle metoder og den visuelle vendingen er en bevisst generering, og analyse av datamateriale i form av bilder. Hun har en bred definisjon av ordet 'bilder', og inkluderer blant annet tegninger, diagrammer, malerier, reklame, video og websider. Forskerens epistemologiske og ontologiske posisjonering innenfor det visuelle handler om å vite gjennom bilder (epistemologi) og hvordan bildene representerer virkeligheter (ontologi). I dette kapittelet knyttes den visuelle vendingen til transkripsjon av materialitet og kroppslige praksiser. Innsikt i akkurat dette kan være vanskelig tilgjengelig uten bruk av videodata og visuelle metoder.

Dette kapittelet tar utgangspunkt i empiri fra et mikroetnografisk forskningsprosjekt jeg har gjennomført med fem barnehagebarn i alderen 1 år og 7 måneder til 2 år og 2 måneder, og med deres barnehagelærer og barne- og ungdomsarbeider. Jeg har valgt ut et kort videoklipp fra dette prosjektet, som gjennom hele kapittelet vil brukes til å undersøke og ha et etisk og analytisk fokus på hvordan forskere kan transkribere og analysere tilstedeværelsen og praksisene til barnehagens yngste barn, og øvrige aktører, på en måte som viser deres agentskap og bidrag. Jeg filmet dette 7 sekunder lange videoopptaket på barnehagens uteområde

3 I sitt dikt «Cascade Experiment» skriver Fulton (1990) «we have to meet the universe halfway».

4 «The pictorial turn». 
en solfylt septembermorgen i 2019. Barnehagelæreren sager i en stor plate sammen med barnegruppen og barne- og ungdomsarbeideren. I dette

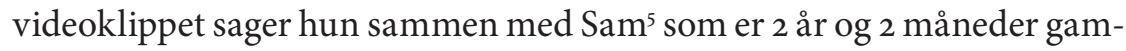
mel. De anvender en vanlig håndsag som er $55 \mathrm{~cm}$ lang. Rundt dem står mange av de andre barna og ser på, disse er ikke synlige i videoklippet.

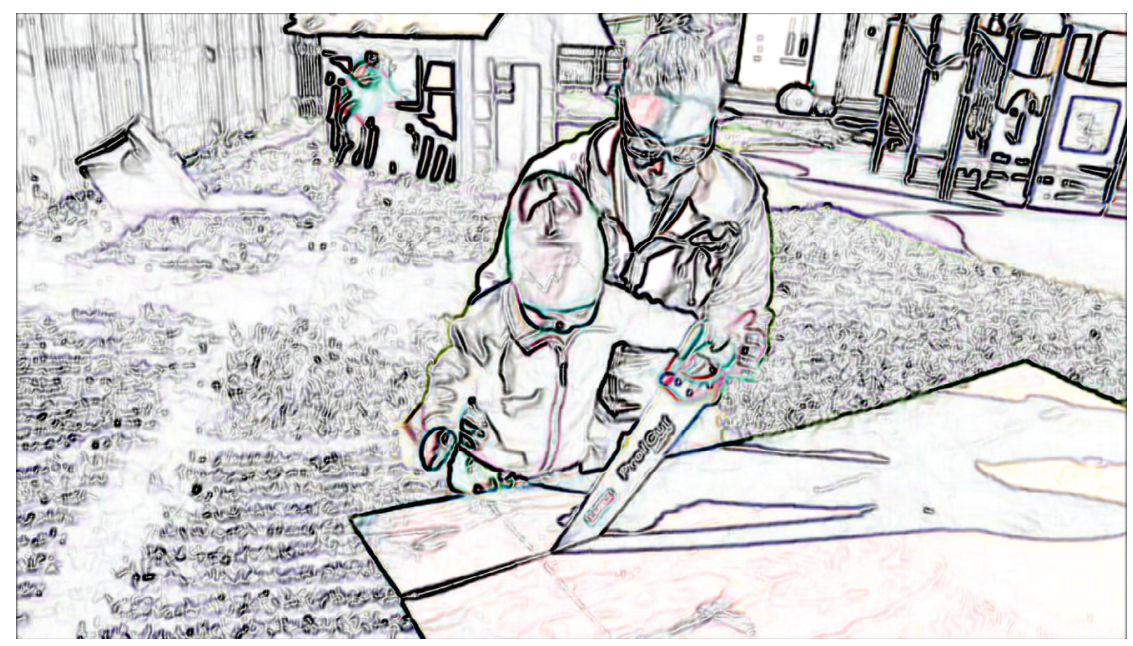

Figur 1. Et skjermbilde med photoshopfilter, fra videoklippet med Sam (2,2 år) som sager.

\title{
Poetisk videotranskripsjon og den kolossussagende Sam
}

\author{
Kolossussagen koblet til Sam
}

tilsvarer en dobbel sag for toddlerkroppen ${ }^{6}$

Kraft strømmer gjennom albue og arm til ytterst ut $i$ kvasse ståltenner

Kolossussagen knirker og skjorer tenner,

og treplata bøyer seg for Sam-sag-kraften

Sikkerhetsnettet av svevende lufthender og smil

består av barnehageloererkropp i aktsom

koordinert tilblivelse rundt en kolossussagende Sam

samt en kolossusSammende sag

5 Pseudonym.

6 Toddler er et begrep som ble introdusert på norsk av forskeren Gunvor Løkken (2004). Begrepet betyr opprinnelig «den som stabber og går» og brukes for å beskrive barn i ett- og toårsalderen (Løkken, 2004, s. 16). 
Det er skapt et mangfold av ulike metoder innenfor forskningsverdenen for å transkribere og omgjøre videoopptak til tekstlige representasjoner. I dette kapittelet vil jeg kun vise fram én fullt og helt tekstlig transkripsjonsmetode, nemlig en metode for poetisk videotranskripsjon som jeg selv har utviklet. Diktet ovenfor er resultatet av en slik prosess, og er en kunstbasert (Leavy, 2018) transkripsjonsmetode. Den er ikke visuell i form av fotografier eller tegninger, men er visuell i kraft av en billedlig og sanselig språkbruk og gir rom for å løfte fram de yngste barna og andre materialiteters eksistens og praksiser. I figur 2 blir prosessen bak transkripsjonen om «Den kolossussagende Sam» vist steg for steg. Øvrige videotranskripsjonseksempler i dette kapittelet består av kombinasjoner av bilder, tegninger og tekst for å vise fram ulike måter å transkribere det samme videoklippet med Sam og sagen. Selv om poetisk transkripsjon er fullt og helt tekstlig, er det som nevnt en visuell transkripsjonsmetode i form av at man skaper tekstlige bilder, noe jeg kommer nærmere inn på i presentasjonen av min prosess for å lage slike poetiske videotranskripsjoner.

I 1997 publiserte Corrine Glesne artikkelen «That Rare Feeling: Re-presenting Research Through Poetic Transcription», hvor hun introduserte en kreativ og eksperimentell form for skriving og analyse som hun valgte å gi navnet poetisk transkripsjon. Gjennom denne formen for akademisk skriving, re-presenterer hun sitt forskningsmateriale, framfor å gjøre en forsøkt objektiv representasjon av det. Glesnes metode omhandler poetisk transkripsjon av intervju og bruk av forskningsdeltageres egne ord, og dette har inspirert mitt eget arbeid med å utvikle en metode for å poetisk transkribere de levende bildene som er i et videoopptak. Glesne understreker viktigheten av å lage seg noen egne regler for den poesien forskeren skal skape, men framhever at det ikke finnes bare én måte å gjøre dette på. Hun framhever betydningen av individuell kreativitet og eksperimentering i møte med ulike former for datamateriale. En av hennes egne regler er at ordene i den poetiske transkripsjonen alltid skal være intervjudeltagerens egne, og at sammenstillingen av ord skal bevare personens snakkemønster og rytme. I utviklingen av min egen metode for poetisk videotranskripsjon, hvor deltagerne ikke nødvendigvis anvender ord og tale, har jeg 
med utgangspunkt i forskningsetiske og kunstneriske overveielser valgt å ha følgende fem regler:

1) Aldri «gi stemme til» og tale på vegne av menneskene i videoklippet. Ikke utgi meg for å vite noe om deres indre verdener, tanker, personligheter eller «essenser».

2) Aldri bruke sammenligninger og metaforer som kan oppleves nedsettende, ærekrenkende, ringeaktende eller på andre måter skadelige for forskningsdeltagerne.

3) Alltid skape tekstlige bilder som viser kjernen, eller essensen, av det materielle arrangementet, aktiviteten og praksisene som foregår i videoklippet.

4) Alltid skape tekstlige bilder som viser forskningsdeltagernes agentskap og handlekraft.

5) Alltid skape tekstlige bilder som er virkelighetsnære, sanselige og stemningsfulle.

Gjennom utviklingen av denne poetiske videotranskripsjonsmetoden har hensikten for meg som forsker vært å dra veksler på poesien og lyrikkens kraft til å bevege, visualisere, sanseliggjøre, stimulere, perspektivere, gi nye innganger til forståelse og til å utfordre tanken. Poesien har samtidig kraft og potensiale til å frambringe følelser, innlevelse, anerkjennelse og empatisk kunnskap både hos forskeren selv og hos leseren. Språkbildene og poesiens virkemidler kan la oss få ta del i en ukjent verden, og i et nytt fenomen, på måter som lar oss forstå virkeligheten på helt nye måter. I eksempelet med «Den kolossussagende Sam» er det gjennom den poetiske videotranskripsjonen mulig å få nye innganger til barnehagevirkeligheten, toddlerkroppen, saging og barnehagelæreres profesjonspraksiser.

Som vi kan se i figur 2, "prosessen med å lage en poetisk videotranskripsjon», består min prosess av fire hovedsteg. Det første steget er å velge ut et videoklipp som transkriberes rikt og deskriptivt. Prosessens andre steg er å velge seg ut tekst (uthevet i grått) og skape betydningsfulle tekstbilder som er lingvistisk og kronologisk tro mot den originale transkripsjonen. Stabilt vedvarende faktorer, som deltagernes plassering, kan flyttes på innad i tekstbildenes kronologier. 


\begin{tabular}{|c|c|}
\hline \multicolumn{2}{|c|}{ POETISK TRANSKRIPSJONSPROSESS FOR VIDEO } \\
\hline Videotranskripsjon (5 sek.) & Poetisk videotranskripsjon \\
\hline STEG 1: Transkripsion fra videoopptak & STEG 2: Tekstbilder tro mot transkripsionen. \\
\hline $\begin{array}{l}\text { Sam står på det grønne gresset i barnehagen med } \\
\text { hoften tett inntil en stor treplate. Med } \\
\text { venstrearmen utstrakt i skulderhøyde holder han }\end{array}$ & $\begin{array}{l}\text { Faktorer som varte over tid i videoklippet kan endre } \\
\text { rekkefølge i de utvalgte tekstbitenes kronologi. }\end{array}$ \\
\hline rundt skaftet til den store, skarpe voksensagen. & Bilde \#1 \\
\hline $\begin{array}{l}\text { Fingrene strekkes helt ut og griper rundt halve } \\
\text { omkretsen av håndtaket. Sagen er } 55 \mathrm{~cm} \text { lang og } \\
\text { står med tennene i et sagkutt i treplaten. Sam er }\end{array}$ & $\begin{array}{l}\text { Sam }[\ldots] \text { holder }[\ldots] \text { den store, skarpe voksensagen. } \\
\text { Sagen tilsvarer } 65 \text { prosent av hans kroppslengde. }\end{array}$ \\
\hline to år gammel, og omtrent $85 \mathrm{~cm}$ lang. Sagen & Bilde \#2 \\
\hline tilsvarer 65 prosent av hans kroppslengde. Sam & Sam beveger sagen uten hjelp. \\
\hline beveger sagen uten hjelp. Bak ham på huk, tett & Sam vrir arm og albue raskt nedover, med litt kraft. \\
\hline inntil, sitter barnehagelæreren hans. Med en arm & Plata buer seg, og sagen gjør motstand. Sagen knirker \\
\hline $\begin{array}{l}\text { på treplaten ser hun på sagbladet som beveger } \\
\text { seg. Hun smiler. For å holde sagen har Sam }\end{array}$ & i sporet. \\
\hline venstre arm høyt og helt utstrakt fra resten av & Bilde \#3 \\
\hline kroppen, og strekker den et stykke inn på & [...] tett inntil, sitter barnehagelæreren hans. [Hun] \\
\hline treplaten der sagen står fast i en $80^{\circ}$ vinkel. Sam & løfter hendene sine opp i det saga går ned, hun smiler \\
\hline vrir arm og albue raskt nedover, med litt kraft. & og posisjonerer dem raskt i luftrommet rundt Sams \\
\hline $\begin{array}{l}\text { Slik beveger han sagen i retning av sin venstre } \\
\text { side, på skrå ned igjennom treplaten. Plata buer }\end{array}$ & hånd og sagens håndtak. \\
\hline seg, og sagen gjør motstand. Sagen knirker i & STEG 3: Billed bruk og sanseliggjoring av teksten \\
\hline $\begin{array}{l}\text { sporet mens den beveger seg i platens kutt. Sam } \\
\text { har blikket ned mot sporet. Barnehagelæreren }\end{array}$ & $\overline{\text { Sammenligninger ved hjelp av similer og metaforer. }}$ \\
\hline løfter hendene sine opp i det saga går ned, hun & Bilde \#1 \\
\hline smiler og posisjonerer dem raskt i luftrommet & Sam er koblet til en kolossus av en sag. \\
\hline $\begin{array}{l}\text { rundt Sams hånd og sagens håndtak. Hun buer } \\
\text { venstre håndflate og fører den på utsiden av }\end{array}$ & For toddlerkroppen er den som to sager kombinert. \\
\hline sagens håndtak, men uten å røre borti den. & Bilde \#2 \\
\hline Håndflaten er noen centimeter under sagen, og & Kraften går gjennom arm og albue helt ut $\mathrm{i}$ \\
\hline følger bevegelsene som Sam skaper. Sam rykker & sagtennene. Sam făr sagen til å knirke og skjære \\
\hline $\begin{array}{l}\text { sagen raskt opp mot høyre igjen, til } 45^{\circ} \text { fra plata. } \\
\left.\iota^{\circ}\right\rfloor \AA h^{\circ} » \text { sier barnehagelæreren. Stemmen bærer }\end{array}$ & tenner. Treplata bøyer seg for kraften deres. \\
\hline med seg auditiv spenning og oppmuntring, det & Bilde \#3 \\
\hline høres ut som en «dette-var-vanskelig-men-du- & Sikkerhetsnettets kraft er alltid tett inntil. \\
\hline klarer-det-åh». Hun smiler. Sagen går like fort & Aktsomt og koordinert med lufthender og smil. \\
\hline $\begin{array}{l}\text { ned mot plata igjen, den knirker skjærende, } \mathrm{og} \\
\text { barnehagelæreren støtter sagen med håndflaten }\end{array}$ & Barnehagelærernettet skapes hvert øyeblikk til. \\
\hline på veien ned. Hun tar den høyre håndflaten rundt & STEG 4: Tilforing av rvtme og musikalitet \\
\hline $\begin{array}{l}\text { midjen til Sam. Han reiser saga raskt oppover } \\
\text { igjen imens den knirker. Barnehagelæreren }\end{array}$ & Endelig utgave av den poetiske transkripsjonen. \\
\hline slipper samtidig saga helt, mens Sam styrer og & Kolossussagen koblet til Sam \\
\hline $\begin{array}{l}\text { gir kraft til sagen. Sam vender hodet og blikket } \\
\text { opp mot håndtaket på sagen. Den har nå beveget }\end{array}$ & tilsvarer en dobbel sag for toddlerkroppen \\
\hline seg opp til $80^{\circ}$ fra plata. Barnehagelærerens & Kraft strommer gjennom albue og arm til ytterst ut $i$ \\
\hline håndflate svever igjen under sagen, hun ser på & kvasse ståltenner. Kolossussagen knirker og skjarer \\
\hline hånden til Sam og smiler. I det han begynner å & tenner, og treplata bøyer seg for Sam-sag-kraften. \\
\hline & \\
\hline $\begin{array}{l}\text { et bekreftende og beundrende «£乏.hh» med et } \\
\text { auditivt og muskulært smil. Hun støtter }\end{array}$ & $\begin{array}{l}\text { Sikkerhetsnettet av svevende lufthender og smil } \\
\text { består av barnehagelaererkropp i aktsom }\end{array}$ \\
\hline $\begin{array}{l}\text { sagskaftet med håndflaten sin igjen på veien ned, } \\
\text { og sier rosende «£Sånn } \uparrow j a » .\end{array}$ & $\begin{array}{l}\text { koordinert tilblivelse rundt en kolossussagende Sam } \\
\text { samt en kolossusSammende sag }\end{array}$ \\
\hline & C 2021 Trine Telnes \\
\hline
\end{tabular}

Figur 2. Prosessen med å lage en poetisk videotranskripsjon. 
I steg tre jobber forskeren kreativt med tekstbildene som ble skapt i steg to, og finner relevante sammenligninger ved bruk av similer ${ }^{7}$ og metaforer. Det fjerde og siste steget utgjør en ny, kreativ del av prosessen hvor forrige versjon av tekstbildene omformuleres på måter som tilfører rytme og musikalitet til språket. Dette kan for eksempel gjøres ved å jobbe med plasseringen av ord, ved å skape rim, alliterasjon, assonans eller bruk av andre virkemidler. Virkemidlene som velges tilpasses innholdet i det originale videoklippet, den originale transkripsjonen fra steg 1, og at de fem nevnte reglene følges.

I den poetiske videotranskripsjonen «Den kolossussagende Sam» valgte jeg i steg 3 å bruke sammenligningen og metaforen koloss, og min versjon kolossus, for å skape indre bilder hos leseren som kan få fram størrelsesforholdet mellom Sam og sagen. Jeg så det som relevant å sette i perspektiv hvor stor denne sagen egentlig er å sage med for toddlerkroppen, og hvordan det ville vært om en voksenkropp skulle anvende en sag med de samme proporsjonene målt mot sin egen kropp. Med utgangspunkt i min egen høyde tilsvarer 65 prosent av min kroppslengde proporsjonalt en sag på 110 centimeter, noe jeg regnet ut i første del av transkripsjonsarbeidet. I steg 4 valgte jeg å ta i bruk koloss-metaforen mer aktivt og gjenta den gjennom hvert av transkripsjonens tre tekstbilder. Avslutningsvis knyttes også kolossbegrepet til Sam, da jeg i den aller siste setningen beskriver en «kolossusSammende sag». Her gjøres Sam om til et verb. Setningen antyder at samtidig som Sam gjør noe med den kolossale sagen, så gjør også sagen noe med den kolossale Sam. På dette viset blir konklusjonen at Sam, i likhet med sagen, er en koloss han også.

Men hva er egentlig en koloss? Ordet koloss kommer av den enorme statuen Kolossen som en gang skal ha stått i havnen på Rhodos. Koloss brukes som en metafor i dagligtalen for å vise til fenomener som overskrider det som regnes for å være vanlige størrelser og proporsjoner («Koloss», 2018). I tillegg til å vise til statuer og størrelser kan koloss også ha

7 Similer er en sammenligning av én ting med én annen ting (Wangensteen, 2021b), for eksempel «hennes hud var hvit som snø». Det er et virkemiddel som skaper indre bilder hos leseren. Dette kan minne om metaforer, men der similene kommer sammen med ordene «som», «slik» eller «lik» og er en sammenligning, så brukes metaforene i overført betydning i stedet for det fenomenet som metaforen representerer (Skadberg, 2021). 
følgende betydning: «If you describe someone or something as a colossus, you think that they are extremely important and great in ability or size» (Collins, 2021). Koloss har altså en trippel betydning. Metaforbruken kan slik synliggjøre at Sam og sagen er svært betydningsfulle, med enorme egenskaper og krefter. Transkripsjonen blir slik en hyllest og et nikk til Sams styrke og ferdigheter i hans mestring av denne gigantiske sagen. Slik jeg ser det gjennom min analyse, gjør Sam og sagen hverandre til kolossuser: Sam gjør sagen til en koloss i størrelsesforholdet mellom dem (sagen er ikke en koloss i hånden på en voksen), samtidig gjør sagen Sam til en koloss gjennom hans kroppslige kraft og mestring.

En av fordelene med en poetisk videotranskripsjon er at forskeren med få ord kan få fram valører og teksturer ved barna og de andre aktørenes tilstedeværelse og praksiser, og ved hjelp av poetiske virkemidler løfte fram deres felles agentskap og bidrag, som når jeg skriver «treplata bøyer seg for Sam-sag-kraften». Utfordringene med denne poetiske transkripsjonsprosessen for videoklipp kan være at det å skape gode similer, metaforer og poetiske (re)presentasjoner av det som skjer i videoen kan kreve mye av forskerens etiske bevissthet, selvstendighet og kreativitet. Dersom forskeren mestrer dette og har et analytisk blikk på de mange ulike aktørenes agentskap, bidrag og samhandling, kan denne transkripsjonsmetoden gi muligheter for å skape tekstlige bilder og virkemidler som løfter fram og gir nye forståelser av barnehagens tidvis målbundne og marginaliserte materialiteter.

\section{Mondadas multimodale transkripsjonskonvensjon}

Jeg vil nå ta steget inn i samtaleanalysens $\left(\mathrm{CA}^{8}\right)$ verden for en ny analyse av videoklippet med «Den kolossussagende Sam», gjennom en adapsjon av Lorenza Mondadas (2019) multimodale transkripsjonskonvensjon. Multimodalitet handler om de mange ulike ressurser som kan benyttes for kommunikasjon og meningsskaping i en sosial gruppe. Verbalspråk utgjør bare en av disse ressursene. Alle modaliteter kan ses som likestilte

$8 \mathrm{CA}=$ conversation analysis 
i sine mulige kapasiteter for å bidra med mening inn i en kompleks semiotisk $^{9}$ helhet for deltagere. Dette kan blant annet være bevegelse, handling, sted, rom og tredimensjonale objekter (Kress, 2011, s. 242). Samtaleanalytikere er interessert i den interne organiseringen av sosiale aktiviteter og interaksjoner som er skapt ved hjelp av varierte visuelle, verbale og kroppslige ressurser, og studerer disse in situ ${ }^{10}$, slik de oppstår kollektivt i sine naturlige sammenhenger (Mondada, 2013). Som navnet tilsier innebærer CA altså en analyse av interaksjoner og samtaler som oppstår naturlig mellom mennesker, hvor verbalspråk og alle andre modaliteter og materialiteter ses på som ressurser for disse menneskenes bruk. En del av de fastsatte rammene og konvensjonene for analysen kan i så måte forstås som antroposentriske ${ }^{11}$, men anvendes også på interaksjon med ikke-menneskelige aktører. Innenfor den samtaleanalytiske tradisjonen analyseres ulike typer lyd- og videoopptak, og i løpet av 1960tallet utviklet Gail Jefferson (2004) mye av det omfattende systemet som i dag brukes av samtaleanalytikere for å transkribere tale og annen adferd i interaksjon. Det benyttes blant annet til å analysere barnehagebarns agentskap i interaksjon med sine barnehagelærere, og byr på muligheter for å kunne gjøre svært detaljerte transkripsjoner av kroppsspråk (Bateman, 2017). I Jeffersons transkripsjonskonvensjon anvendes ulike symboler for å markere aspekter som tonefall, hastighet, pauser, innpust, utpust og lignende. Grad-tegnet $\left(^{\circ}\right)$ brukes for eksempel til å markere en stille eller myk stemme, og dobbelt grad-tegn $\left({ }^{\circ}\right)$ indikerer en spesielt stille stemme, som hvisking. Smilende stemme markeres med tegnet for britiske pund (E). Piler markerer tonehøyde. Pauser med stillhet markeres i parentes. Synlige gester, mimikk og lignende plasseres i dobbel parentes (Hepburn \& Bolden, 2013, s. 70). CA har ofte vært logosentrisk, men det foregår en visuell vending hvor samtaleanalytikere i større grad har begynt å utvikle måter å transkribere visuell informasjon, den materielle verden og multimodale ressurser på (Luff \& Heath, 2015; Streeck et

\footnotetext{
9 Semiotikk er «læren om tegn (også ord) og bruken av tegn, tegnlære» (Wangensteen, 2021a).

10 In situ = på stedet, i situasjonen.

11 Antroposentrismen og den antroposentriske verdensoppfattelsen har mennesket i sentrum; her dreier alle andre fenomener seg rundt mennesket og menneskets eksistens («Antroposentrisk», 2021).
} 
al., 2011). Basert på Jeffersons (2004) system har Lorenza Mondada (2019) utviklet egne multimodale transkripsjonskonvensjoner for kroppshandlinger som hun jevnlig oppdaterer. Kortversjonen av den ser slik ut (Mondada, 2019, s. 2, min oversettelse):

* $\quad$ Beskrivelse av ikke-verbale handlinger ${ }^{12}$ er avgrenset mellom

$++\quad$ to identiske symboler (ett symbol per deltager og per type handling)

$\Delta \Delta$ som synkroniseres med strekninger av korrespondanse eller tidsindikasjoner.

* --> Handlingen beskrevet fortsetter på tvers av påfølgende linjer

---->^ fram til det samme symbolet er nådd.

> Handlingen beskrevet starter før utdragets begynnelse.

--->> Handlingen beskrevet fortsetter etter utdragets slutt.

..... Handlingens forberedelse.

---- Handlingens toppunkt nås og vedlikeholdes.

,’, Handlingens tilbaketrekning.

ric Deltager som utfører en ikke-verbal handling, identifiseres med små bokstaver.

fig Det nøyaktige øyeblikket da et skjermbilde ${ }^{13}$ er tatt

\# $\quad$ er angitt med et tegn (\#) som viser øyeblikkets posisjon innen en gitt kronologi.

Bak «ric» nevnes det her hvordan deltagere som utfører ikke-verbale handlinger skal annoteres. Regelen om at verbalt handlende deltagere skal stå øverst i store bokstaver, er ikke med i denne kortversjonen, og nevnes først eksplisitt i konvensjonens side 3. Logosentrismen henger slik igjen i strukturen. Timing, temporal posisjon og kronologi er hovedprinsippet $\mathrm{i}$ konvensjonen. Det kan se ut til at tale som hovedregel utgjør tidsmålet som alle de ikke-verbale handlingene skal «henges» på, noe som kan by på problemer i arbeidet med mitt videoklipp som kun har én taler: barnehagelæreren.

12 Embodied actions. Siden alle handlinger er legemliggjorte, også talespråk, valgte jeg her å oversette «embodied actions» til ikke-verbale handlinger, som her blir mer presist enn «kroppslige handlinger».

13 Jeg har anvendt programmet Adobe Photoshop for å legge på filter som anonymiserer forskningsdeltagerne. 
I figur 3 har jeg gjort en adapsjon av Mondadas konvensjon for å transkribere videoklippet med Sam. Tilpasningen jeg har gjort av konvensjonen, er en antegnelse av sekunder og mikrosekunder i parentes under hver nummerte hovedhandling i margen. Slik får jeg en vertikal tidslinje som tydeliggjør temporal posisjonering. Samtaleanalyse bygges ofte opp rundt et system kalt turtaking, hvor tur representerer den tilmålte tiden samtalepartnere veksler på å føre ordet (Svennevig, 2018). I tillegg fokuserer CA-forskere også på «turns-of-action» (Kääntä, 2010). Siden transkripsjonen av mitt videoklipp ikke kan baseres på turtakende talere, bygges den i min adapsjon rundt aktiviteten som foregår (sagingen), og hver nummererte linje i fet skrift representerer en betydningsfull og meningsskapende handling i interaksjonen mellom deltagerne. Mondada (2019) skriver at konvensjonen er laget for å kunne annotere alle mulige relevante kroppslige handlinger som skjer samtidig med prating eller ved fravær av verbal prat, slik som blikk, gestikulering, kroppsholdning, bevegelse, bruk av artefakter og lignende. Selv om Mondada skriver at systemet skal kunne anvendes for å transkribere alle mulige handlinger som skjer, også i situasjoner hvor det er fravær av verbalspråk, opplevde jeg i transkripsjonsforsøket i figur 3 at dette ble svært utfordrende å få til i praksis. Det kunne vært nyttig i sage-transkripsjonen å bruke de følgende annotasjonene:

.... Handlingens forberedelse.

---- Handlingens toppunkt nås og vedlikeholdes.

,’,' Handlingens tilbaketrekning.

For eksempel kunne jeg i linje 3 ha brukt «----» der sagen når sitt toppunkt, og «.....» eller «,,,,» når sagen går ned mot platen igjen. Problemet er at disse handlingene ikke kan måles tidsmessig opp mot noen annen handling som skjer simultant, og at jeg da ikke kan vise toppunktet «----» sett i forhold til noe annet. Det finnes her i denne videoen ikke talehandlinger å knytte disse bevegelsene til. Sagen og Sams arm er i en kontinuerlig og simultan flyt av bevegelser, uten pauser, og det samme gjelder bevegelsene barnehagelæreren gjør med sine hender rundt sagen. Jeg valgte derfor å beskrive sagens toppunkt med ord. 


\section{VIDEOKLIPPET TRANSKRIBERT MED EN ADAPSJON AV MONDADAS KONVENSJON}

BAR = barnehagelærer .

BARs lyder $=a$, BARs bevegelser $=\odot$, BARs blikk $=\odot$

$\mathrm{SAM}=\operatorname{Sam}(2,2$ år). SAMs bevegelser $=\mho$, SAMs blikk $=$

$\mathrm{SAG}=$ sagen. SAGs lyder $=\neq$

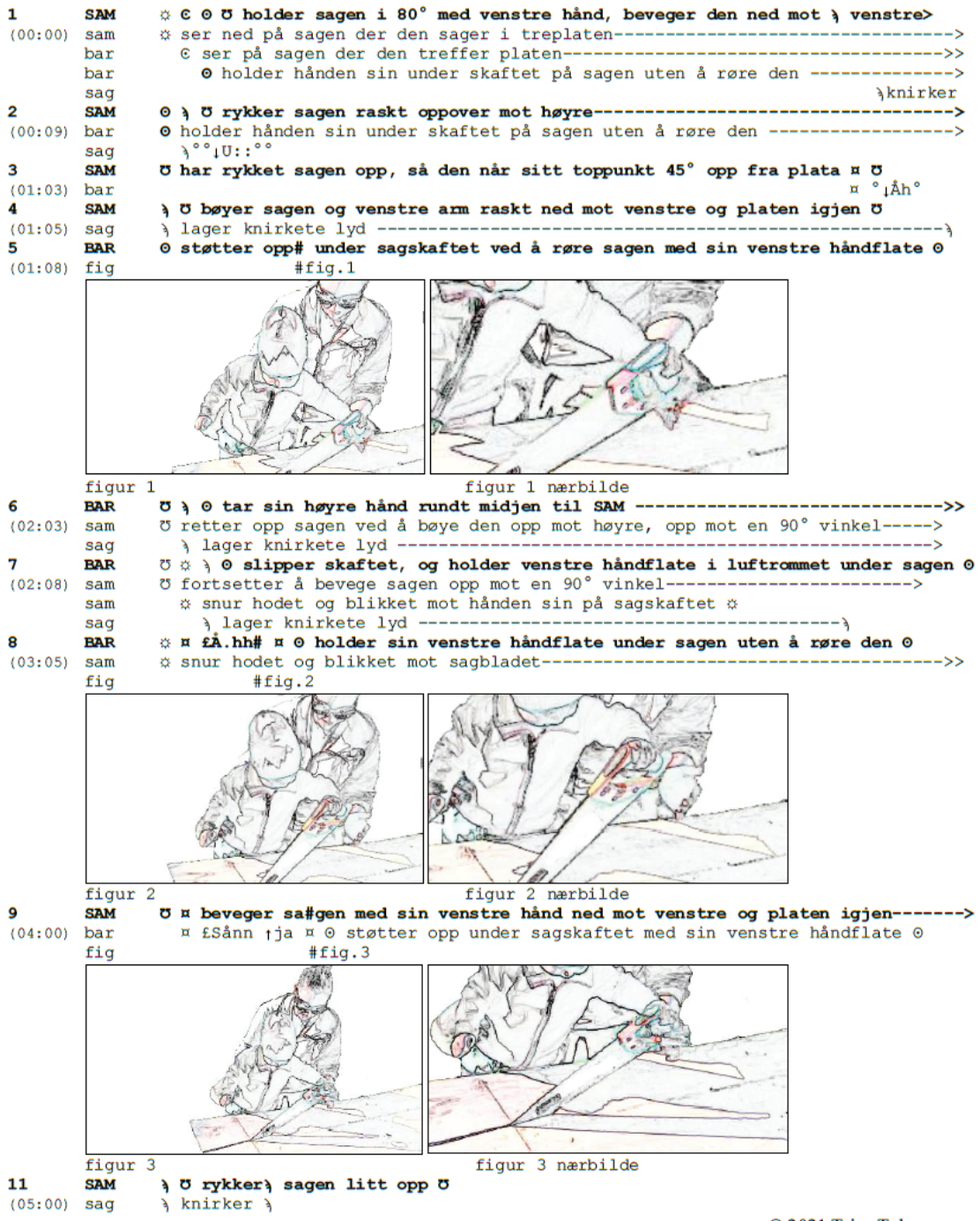

(05:00) sag

C 2021 Trine Telnes

Figur 3. En adapsjon av Mondadas multimodale transkripsjonskonvensjon. 
I snitt tilsvarer hver nummererte linje i transkripsjonen på forrige side ett halvt sekund, og hver linje markerer betydningsfulle hendelser som skjer gjennom sekvensen. Mondada (2019, s. 7) skriver at for «silent embodied actions» skal det lages hovedlinjer i fet skrift uten navn i margen, hvor tiden er hovedrolleinnehaveren. Her skal antall mikrosekund med fravær av tale (såkalte «pauser») representeres. Linjen måler da tidshandlingene i en horisontal tidsbane, à la dette:
1
$(0.1) \odot(0.2)$
(0.3)
(0.4)
bar
$\odot$ holder hånden sin under skaftet på sagen uten å røre den
--->

Framfor den vertikale tidslinjen jeg har laget, får vi da en detaljert horisontal tidslinje å «henge» øvrige handlinger på i tid. Det nye problemet som kan oppstå med en slik løsning, er at omtrent hele transkripsjonen vil bestå av slike hovedlinjer, og at den allerede begrensede plassen forskeren har til å komme med adekvate beskrivelser på underlinjene, vil begrenses ytterligere ut fra hvor handlingenes plassering på disse tidslinjene blir. Det vil igjen umuliggjøre rike beskrivelser av de relevante kroppslige handlingene, som bevegelsene av sagen og lignende. Dersom «bar» (barnehagelæreren) sin håndbevegelse under sagen i eksempelet over hadde startet etter 0,5 sekunder og ikke etter o,2, kunne antall centimeter på handlingens designerte linje ha blitt for knapp til å romme en forståelig beskrivelse.

Mondadas (2019) multimodale transkripsjonskonvensjon har noen fordeler i form av at forskeren kan bruke symboler og skjermbilder for å synliggjøre ulike kroppslige handlinger, og kan få stor nøyaktighet i gjengivelse av handlingsforløp og rekkefølge. Samtidig skriver hun at kroppslige handlinger som hovedprinsipp skal beskrives kort, økonomisk og utvetydig. Denne begrensningen kan være en fordel i noen analyseprosesser, men byr på utfordringer når jeg skal transkribere og analysere tilstedeværelsen og praksisene til barnehagens yngste barn, og andre menneskelige og ikke-menneskelige aktører, på en måte som viser deres agentskap og bidrag. Strukturen i Mondadas multimodale konvensjon kan utilsiktet marginalisere ikke-talende aktører, ulike materielle forutsetninger og ikke-kommunikative praksiser som den i 
mitt eksempel (saging). Det er for eksempel vanskelig å få fram sagens «kvasse ståltenner», som ikke er synlige i skjermbildene. Det blir lite rom for rike beskrivelser av ulike materialiteters betydninger for praksisene. Transkripsjonen er svært oversiktlig og bidrar med tekst og bilder til å vise Sams, barnehagelærerens og sagens silent embodied actions, og rekkefølgene på disse, men Mondadas konvensjon er ikke den mest fleksible eller optimale for å synliggjøre ikke-talende aktører som sagen og platens agentskap og bidrag.

\section{Tegneserietranskripsjon}

I det videre analysearbeidet med videoklippet med Sam, sagen og barnehagelæreren vil jeg fortsatt holde meg i samtaleanalysens verden, i kombinasjonen med kunstbasert forskning (Kuttner et al., 2018). Jeg vil her gjøre en visuell vending inn mot bruken av tegning i transkripsjon og analysearbeid (Albert et al., 2019; Olaussen, 2018; Bjørkøy, 2020). Her har blant annet Eric Lauriers (2014, 2019) grafiske transkripsjoner inspirert meg i mitt eget arbeid til å utvikle det jeg har valgt å kalle for tegneserietranskripsjon. I likhet med Mondadas metode er også dette en form for multimodal transkripsjon, som vektlegger og synliggjør ikke-verbale handlinger. Innenfor tegneseriestripens konvensjoner kombineres her det visuelle og det temporale med de romlige og materielle forutsetningene for handlingene. Der Laurier i det han selv kaller grafiske transkripsjoner bruker skjermbilder og snakkebobler uten Jeffersons (2004) konvensjoner, tegner jeg handlingene i videoklippene for hånd, og kombinerer disse med Jeffersons symbolbruk. I eksempelet i figur 4 anvendes gradsymbol, piler, punktum og pund-tegnet for å markere kvaliteter i barnehagelærerens stemme. Dette bidrar til at forskeren bedre kan forstå det som foregår i samhandlingen, få innsikt og viktig kunnskap om stemmebruk som profesjonspraksis, og se hvordan ulike sider ved stemmen kan være meningsbærende. Detaljene i stemmens ulike utrykk kan for eksempel bære med seg auditive smil, spenning, bekreftelse, beundring, støtte og oppmuntring. Kronologien $\mathrm{i}$ handlingene vises gjennom tegneserierutene, og i øverste venstre hjørne markeres de ulike øyeblikkenes tidsposisjoner i sekunder. Tegningene i disse tegneseriene har jeg skapt med 
tusjer og kalkerpapir lagt over PC-skjermen med nøye utvalgte skjermbilder fra videofilmen. I dette første eksempelet har jeg brukt svart og blå tusj, og laget overlappende tegninger av det som skjer i videoklippet. Dette for å forsøke å synliggjøre og gjenskape bevegelsene til deltagerne. Gjennom å «tegne meg gjennom videoopptaket» bidro hånden og berøringssansen min til at jeg kunne tone meg inn på innholdet i videoklippet ved bruk av flere sanser enn bare hørsels- og synssansen. Tegneprosessen ga meg nye forståelser av det komplekse samspillet mellom de ulike aktørene, samt en større innlevelse og empatisk forståelse av deres praksiser.

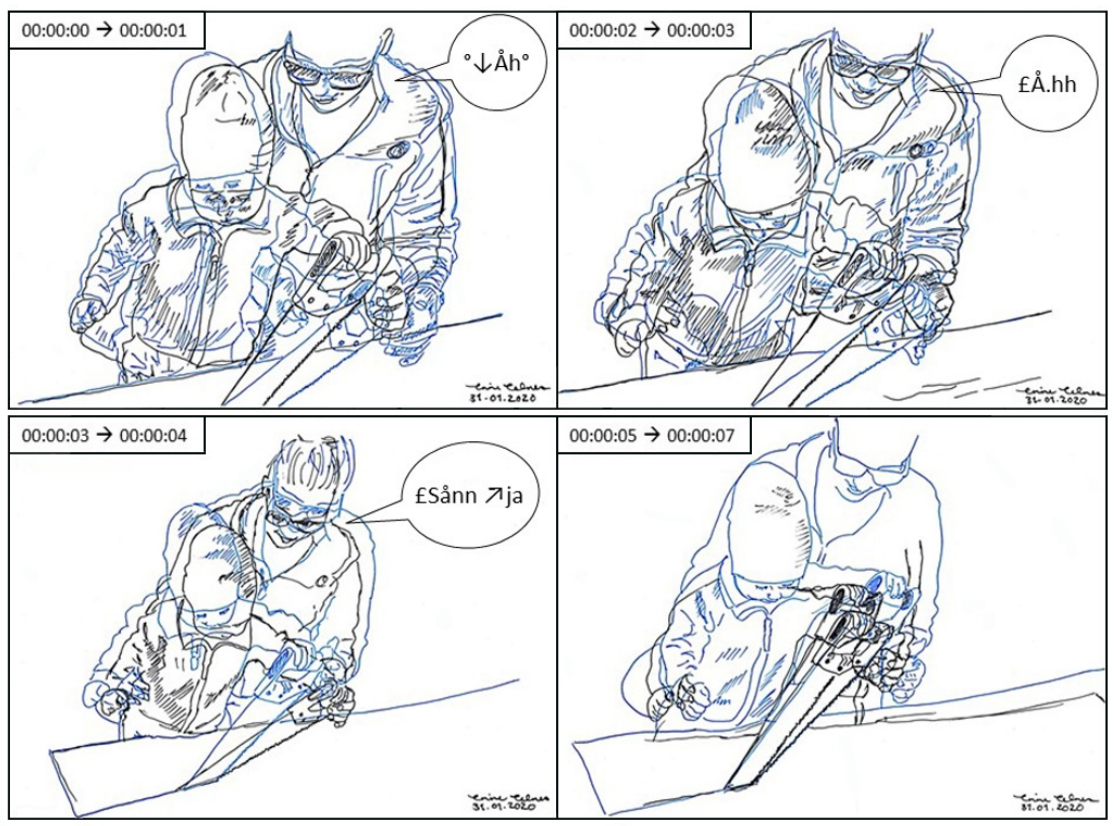

Figur 4. Sam (2,2 år), sagen og barnehagelæreren sager i plate. Tegneserie med overlapp. Flere overlappende tegninger i hver rute for å få fram bevegelsene.

I figur 4 bringes som nevnt deltagernes stemmebruk inn gjennom snakkebobler transkribert med Jeffersons (2004) konvensjoner. Sammen med tegningene er disse symbolene med på å visualisere noe av forskningsdeltagernes kroppsspråk og praksiser. Her viser grad-tegnene $\left(^{\circ}\right)$ i den første snakkeboblen at barnehagelæreren har en stille eller myk stemme, og pilen som peker ned markerer at intonasjonen og tonehøyden på «åh» går ned. Tegnet for britiske pund $(\mathfrak{E})$ i de to neste snakkeboblene markerer 
en smilende stemme. Sam lager ingen lyder i løpet av dette videoklippet. Ved å la tegninger av hans materialitet, blikk og bevegelser dominere transkripsjonen, synliggjøres hans agentskap. Reduksjonen av skriftspråket kan forsterke og feste våre blikk på Sams lydløse handlinger. De overlappende strekene i tegningene bidrar her til å gi et visuelt inntrykk av de hurtige og komplekse bevegelsene forskningsdeltagerne gjorde i videoen. Utfordringen er at denne kompleksiteten og detaljrikdommen i tegningene kan gjøre at det blir utydelig, uskarpt, og at vi «ikke ser bevegelsene for alle bevegelsene», det kan sammenlignes med å ta et fotografi med lang eksponeringstid. Med bakgrunn i dette har jeg i figur 5 laget en ny tegneserieversjon av samme sekvens uten overlapp, for å kunne sammenligne effekten av disse to ulike måtene å lage tegneserietranskripsjoner på.

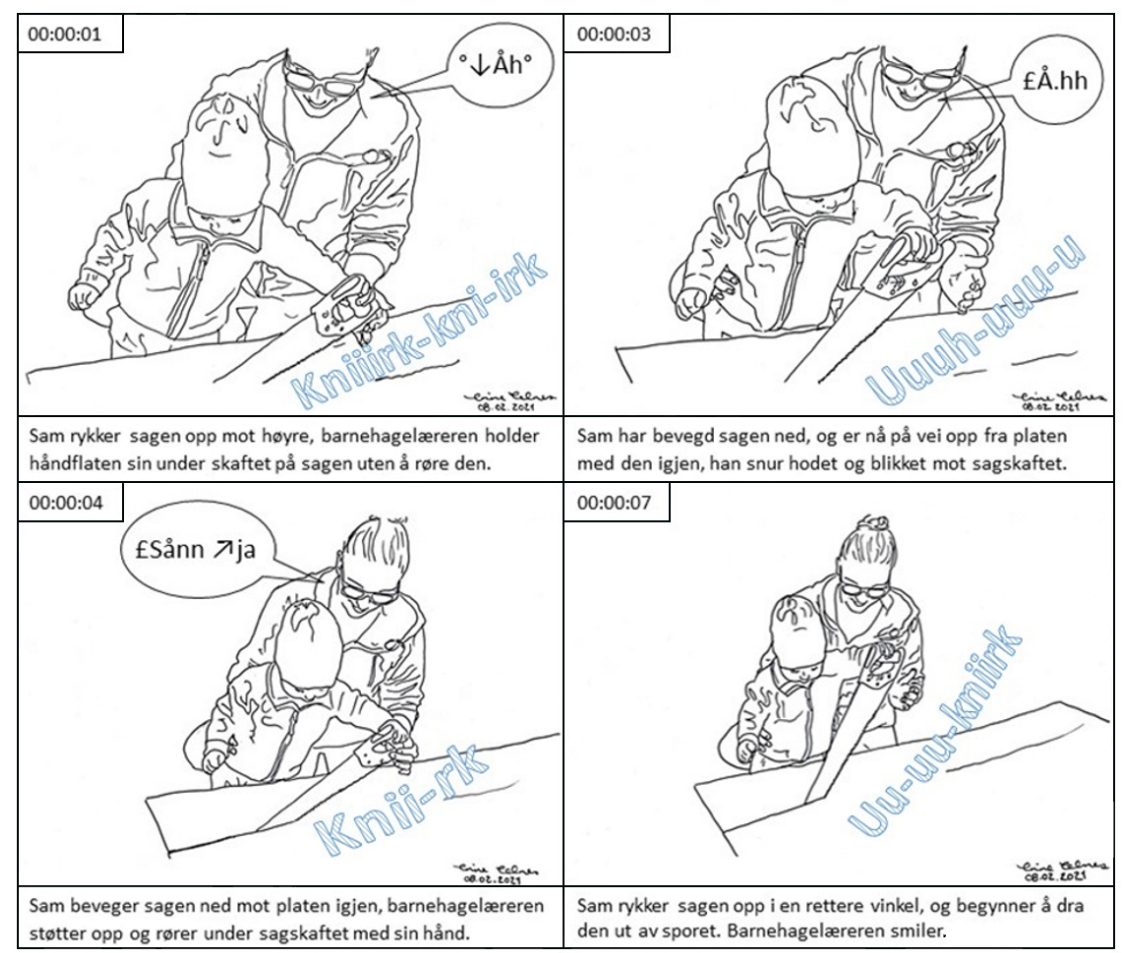

Figur 5. Sam (2,2 år), sagen og barnehagelæreren sager i plate. Tegneserie med tekstbokser under hver rute, og onomatopoetikon for å beskrive det som skjer.

I figur 5 blir ikke deltagernes kontinuerlige bevegelighet like synlige som i figur 4, så her har jeg benyttet tekstbokser under tegneserierutene for å beskrive deltagernes bevegelsesmønster. Tegneserieformatet gir også rom 
for å legge til andre aspekter, som for eksempel onomatopoetikon, som jeg her har satt inn med blå «wordart», altså lydmalende ord som her representerer de ulike lydene sagen lager. Det er mulig å kombinere alle virkemidlene i de to figurene inn i en og samme tegneserietranskripsjon, og å ha så mange bilderuter som den enkelte ønsker. Ved å ta inn tekstbokser og onomatopoetikon i tegneserien i figur 4 slik som i figur 5, kan det igjen bidra til mer tydelighet sammen med de overlappende bevegelsene. I begge tegneseriene bidrar hybriden mellom tekst og tegning til å synliggjøre de kroppslige, romlige og materielle aspektene i samhandlingen mellom sag, plate, Sam og barnehagelæreren. Tegningene kan bidra til innsyn og transparens inn i hendelsens materielle og romlige forutsetninger, samtidig som det ivaretar deltagernes anonymitet. Tegneserietranskripsjon kan være en oversiktlig og lesbar metode å benytte for å analysere tilstedeværelsen og praksisene til barnehagens yngste barn, og andre menneskelige og ikke-menneskelige aktører, på en måte som viser deres agentskap og bidrag. Alle relevante og tause materialiteter kan her potensielt gjøres like synlige og likeverdige i framstillingen. En utfordring kan være at det er en tidkrevende metode, men det er også de foregående transkripsjonsmetodene jeg har presentert.

\section{Avslutning}

I dette kapittelet om visuelle vendinger i videoanalyse, har jeg som video- og barnehageforsker gått i dybden på ett videoklipp for å undersøke utvalgte metoder for transkripsjon i møter med barnehagens marginaliserte og målbundne materialiteter. Jeg har utforsket hvordan ulike former for visualisering av videodata kan få fram tilstedeværelsen og praksisene til barnehagens yngste barn, og andre menneskelige og ikke-menneskelige aktører, på en måte som viser deres agentskap og bidrag. Respektfull og likeverdig behandling av de ulike deltagerne i videoklippene er av forskningsetisk betydning, og noe de forskningsetiske retningslinjene vektlegger (NESH, 2016). Gjennom en adapsjon av Mondadas multimodale konvensjon, samt ved å utvikle to egne former for kunstbaserte videotranskripsjoner, poetisk videotranskripsjon og tegneserietranskripsjon, har jeg vist ulike måter å synliggjøre Sam, sagen, 
platen og barnehagelærerens agentskaper og bidrag i sage-aktiviteten. Mitt håp er at dette arbeidet kan anvendes av andre, og at det bidrar til at kapittelets lesere finner inspirasjon for sin egen videoforskning, og for sine egne videotranskripsjoner.

God og etisk vitenskapelig praksis skal søke etter «sikker, dekkende og relevant kunnskap» skriver NESH (2016, s. 6). Men vil dette være mulig å oppnå ved å kun transkribere og analysere de hørbare talehandlingene i et videoopptak fra barnehagen, eller fra andre læringsarenaer? Det kroppslige, erfaringsbaserte, estetiske, materielle og multimodale kan være vanskelig å gjengi ved et ensidig fokus på menneskene og deres verbalspråk. Betydningen av materialitet, nonverbale handlinger og kroppslig interaksjon forsterkes i forskning med ett og to år gamle barn, som i stor grad uttrykker seg nonverbalt. Selv om det innenfor videoforskning har begynt å bli større oppmerksomhet rundt det multimodale og det materielle, så er en del av transkripsjonsmetodene fortsatt logosentriske og bygget opp rundt talespråk. Men hvorfor er det slik? Hvorfor er det så mange transkripsjonsmetoder som sentrerer tale på bekostning av andre uttrykk og praksiser? Med den enorme detaljrikdommen som ligger i datamaterialet som forskere skaffer seg ved bruk av video, så burde også transkripsjonene gjenspeile noe av den samme kompleksiteten og rikdommen. Å bryte ordets hegemoni med hybridisering av bilder, tegning og transkripsjon kan bidra til transparens, til å begrense marginalisering, til å skape nye kunnskapsformer og til å løfte fram de ulike aktørenes mangefasetterte ressurser og bidrag. Metodene utforsket gjennom dette kapittelet byr på ulike styrker og svakheter som de kan bidra med inn i videoanalyser. De gir ikke tilgang til tankeverdener, men alle har til felles at de kan synliggjøre det kroppslige, romlige og materielle. Som nevnt innledningsvis vil alle former for transkripsjon innebære at vi som forskere gjør valg basert på våre forskningsfokus og problemstillinger, og alle transkripsjonsmetoder må derfor vurderes i lys av de kontekstene de anvendes i og forskningens formål. Det er også av stor betydning at transkripsjonsformene i løpet av hele prosessen kombineres med kompetanse og dybdekunnskap innenfor det aktuelle praksisfeltet som studeres (Knoblauch, 2005), som for eksempel barnehagepedagogikk. 
Med mitt fokus, og problemstillingen for dette kapittelet, var det de to transkripsjonsformene som jeg personlig har utviklet som i analysen av videoklippet ga meg mest rom for utfoldelse av egen forskerkreativitet og til å synliggjøre Sams agentskap. Jeg vil oppfordre alle andre videoforskere til å eksperimentere med det visuelle i egne videodata, til å finne nye måter å transkribere rikdommen som video byr på, og til å bli visuelle videoforskere. Mine visuelle transkripsjonsvendinger har blant annet gitt meg muligheten til å kunne se de ulike bevegelsene og materialitetenes betydning for interaksjonen mellom forskningsdeltagerne, til å se Sam som en kolossusSam, til å se sagen som en kolossussag og til å se barnehagelæreren som et sikkerhetsnett av svevende lufthender og smil.

\section{Referanser}

Albert, S., Heath, C., Skach, S., Harris, M. T., Miller, M. \& Healey, P. G. T. (2019). Drawing as transcription: How do graphical techniques inform interaction analysis? Social Interaction. Video-Based Studies of Human Sociality, 2(1). https://doi.org/10.7146/si.v2i1.113145

Antroposentrisk. (2021). I Det norske akademis ordbok. https://naob.no/ordbok/ antroposentrisk

Bae, B. (2007, 10. januar). Å se barn som subjekt - noen konsekvenser for pedagogisk arbeid i barnehage. Kunnskapsdepartementet. https://www.regjeringen.no/ no/tema/familie-og-barn/barnehager/artikler/a-se-barn-som-subjekt---noenkonsekvense/id440489/

Barad, K. (2007). Meeting the universe halfway: Quantum physics and the entanglement of matter and meaning. Duke University Press.

Bateman, A. (2017). Hearing children's voices through a conversation analysis approach. International Journal of Early Years Education, 25(3), 241-256. https:// doi.org/10.1080/09669760.2017.1344624

Bezemer, J. \& Mavers, D. (2011). Multimodal transcription as academic practice: A social semiotic perspective. International Journal of Social Research Methodology, 14(3), 191-206. https://doi.org/10.1080/13645579.2011.563616

Bjørkøy, I. (2020). Sang som performativ for samspill i småbarnspedagogisk praksis [Doktorgradsavhandling]. NTNU.

Boxenbaum, E., Jones, C., Meyer, R. E. \& Svejenova, S. (2018). Towards an articulation of the material and visual turn in organization studies. Organization Studies, 39(5-6), 597-616. https://doi.org/10.1177/0170840618772611 
Collins. (2021). Colossus. I COBUILD advanced English dictionary. https://www. collinsdictionary.com/dictionary/english/colossus

Fulton, A. (1990). Powers of congress. David R. Godine.

Glesne, C. (1997). That rare feeling: Re-presenting research through poetic transcription. Qualitative Inquiry, 3(2), 202-221. https://doi.org/10.1177/ 107780049700300204

Hammersley, M. (2010). Reproducing or constructing? Some questions about transcription in social research. Qualitative Research, 10(5), 553-569. https://doi.org/10.1177/1468794110375230

Hepburn, A. \& Bolden, G. B. (2013). The conversation analytic approach to transcription. I J. Sidnell \& T. Stivers (Red.), The handbook of conversation analysis (s. 57-76). Blackwell Publishing Ltd.

James, A. (2007). Giving voice to children's voices: Practices and problems, pitfalls and potentials. American Anthropologist, 109(2), 261-272. https://doi.org/10.1525/ aa.2007.109.2.261

James, A., Jenks, C. \& Prout, A. (1998). Theorizing childhood. Polity Press.

Jefferson, G. (2004). Glossary of transcript symbols with an introduction. I G. H. Lerner (Red.), Conversation analysis: Studies from the first generation (s. 13-31). John Benjamins Publishing Company.

Johannesen, N. (2016). Medvirkning som tiltale: Møter med små barns uttrykk, pedagogers tenkning og tekster av Emmanuel Levinas [Doktorgradsavhandling]. Universitetet i Stavanger.

Karlsson, J. (2012). Visual methodologies. I J. Arthur, M. Waring, R. Coe \& L. V. Hedges (Red.), Research methods and methodologies in education (2. utg., s. 94-101). Sage.

Knoblauch, H. (2005). Focused ethnography. Forum: Qualitative Social Research, 6(3), Artikkel 44.

Koloss. (2018). I Store norske leksikon. https://snl.no/koloss

Kress, G. (2011). 'Partnerships in research': Multimodality and ethnography. Qualitative Research, 11(3), 239-26o. https://doi.org/10.1177/1468794111399836

Kristensson Uggla, B. (2019). En strävan efter sanning: Vetenskapens teori och praktik. Studentlitteratur.

Kuttner, P. J., Sousanis, N. \& Weaver-Hightower, M. B. (2018). How to draw comics the scholarly way: Creating comics-based research in the academy. I P. Leavy (Red.), Handbook of arts-based research (s. 396-422). The Guilford Press.

Kääntä, L. (2010). Teacher turn-allocation and repair practices in classroom interaction: A multisemiotic perspective [Doktorgradsavhandling]. University of Jyväskylä.

Laurier, E. (2014). The graphic transcript: Poaching comic book grammar for inscribing the visual, spatial and temporal aspects of action. Geography Compass, 8(4), 235-248. https://doi.org/10.1111/gec3.12123 
Laurier, E. (2019). The panel show: Further experiments with graphic transcripts and vignettes. Social Interaction. Video-Based Studies of Human Sociality, 2(1). https://doi.org/10.7146/si.v2i1.113968

Leavy, P. (2018). Handbook of arts-based research. The Guilford Press.

Logosentrisme. (2021). I Det norske akademis ordbok. https://naob.no/ordbok/ logosentrisme

Luff, P. K. \& Heath, C. (2015). Transcribing embodied action. I D. Tannen, H. E. Hamilton, D. Schiffrin \& C. T. Adger (Red.), The handbook of discourse analysis (2. utg., s. 447-465). Wiley Blackwell.

Luff, P. K. \& Heath, C. (2019). Visible objects of concern: Issues and challenges for workplace ethnographies in complex environments. Organization, 26(4), 578-597. https://doi.org/10.1177/1350508419828578

Løkken, G. (2004). Toddlerkultur: Om ett- og toåringers sosiale omgang i barnehagen. Cappelen Akademisk Forlag.

Marchand, J. S. (2018). Non-human agency. I R. Braidotti \& M. Hlavajova (Red.), Posthuman glossary (s. 292-295). Bloomsbury Academic.

Mayall, B. (2002). Towards a sociology for childhood: Thinking from children's lives. Open University Press.

Millet, A. \& Estève, I. (2012). Transcribing and annotating multimodality: How deaf children's productions call into the question the analytical tools. I J.-M. Colletta \& M. l. Guidetti (Red.), Gesture and multimodal development (s. 175-197). John Benjamins.

Mitchell, W. J. T. (1995). Picture theory: Essays on verbal and visual representation. University of Chicago Press.

Mondada, L. (2019). Conventions for multimodal transcription, version 5.0.1. https:// www.lorenzamondada.net/multimodal-transcription

NESH. (2016). Forskningsetiske retningslinjer for samfunnsvitenskap, humaniora, juss og teologi (4. utg.). De nasjonale forskningsetiske komiteene.

Nordbø, B. (2018, 17. april). Marginalisering. I Store norske leksikon. https://snl.no/ marginalisering

Olaussen, I. O. (2018). Animasjon som multimodal analyse av fortelleruttrykk i barnehagen. Journal for Research in Arts and Sports Education, 2(1), 108-122. https://doi.org/10.23865/jased.v2.910

Punch, S. (2002). Research with children: The same or different from research with adults? Childhood, 9(3), 321-341. https://doi.org/10.1177/0907568202009003005

Skadberg, N. F. (2021). Metafor. I Bokmålsordboka. https://ordbok.uib.no/perl/ ordbok.cgi?OPP=metafor\&ant_bokmaal=5\&ant_nynorsk=5\&bokmaal=+ \&ordbok=begge

Streeck, J., Goodwin, C. \& LeBaron, C. D. (2011). Embodied interaction: Language and body in the material world. Cambridge University Press. 
Svennevig, J. (2018, 30. desember). Samtaleanalyse. I Store norske leksikon. https:// snl.no/samtaleanalyse

Valentine, K. (2011). Accounting for agency. Children \& Society, 25(5), 347-358. https://doi.org/10.1111/j.1099-0860.2009.00279.x

Wangensteen, B. (2021a). Semiotikk. I Bokmålsordboka. https://ordbok.uib.no/perl/ ordbok.cgi?OPP=semiotikk\&ant_bokmaal=5\&ant_nynorsk=5\&bokmaal=+ \&ordbok=bokmaal

Wangensteen, B. (2021b). Simile. I Bokmålsordboka. https://ordbok.uib.no/perl/ ordbok.cgi?OPP=simile

Yanow, D. (2010). Giving voice to space: Academic practices and the material world. I A. van Marrewijk \& D. Yanow (Red.), Organizational spaces: Rematerializing the workaday world. (s. 139-158). Edward Elgar Publishing Limited. 


\section{Del 2}

Fleksibilitet og mangfold i videoforskning på ulike læringsarenaer 



\title{
KAPITTEL 4
}

\section{Video-stimulated recall som datainnsamlingsmetode}

\section{Julie Lysberg}

\author{
Bodø kommune og Nord universitet
}

\begin{abstract}
This chapter aims to present the data collection method video-stimulated recall (VSR) by describing what the method entails, what kind of data it can provide, and how it can be carried out in qualitative research. The method is based on video observation with a subsequent interview, where video sequences from natural situations are used to support reflections and dialogue. The focus will be on opportunities and the types of data the method provides access to and will simultaneously shed light on methodological considerations related to the method's use. VSR is an advanced interview technique based on video observation with a subsequent interview. Selected sequences from the original situation are used to support the informant's recall of thoughts in, and reflection on, the situation. The method has taken different forms based on different research interests in different research contexts. There is, therefore, no straightforward procedure or template for how to conduct a stimulated recall study. By presenting a detailed description of the data collection process as it was carried out in one project, the chapter seeks to understand the data collection method. A selection of empirical data will be presented to exemplify the types of data this approach can provide.
\end{abstract}

Keywords: teacher reflection, teamwork, stimulated recall, video-stimulated recall

\section{Introduksjon}

Når man skal gjennomføre en vitenskapelig studie og velge egnet metode, står man overfor to enkle spørsmål: Hva prøver studien å finne ut av? Hvilke metoder gir de beste mulighetene for å finne dette ut? Dersom man er interessert i deltakeres tanker i, og refleksjoner om, bestemte 
situasjoner eller hendelser, kan video-stimulated recall (VSR) være et egnet verktøy. Videoopptak av autentiske situasjoner som utgangspunkt for intervju, muliggjør en detaljert studie av deltakernes refleksjoner. $\AA$ stimulere til refleksjoner med støtte av video, initierer gjenkalling av tanker i situasjonen og gir deltakerne assosiasjoner til et bredere bilde (Nind, 2016). Hvis man er ute etter å få folk å huske hva de tenkte gjorde i en situasjon og reflektere rundt det, kan VSR være en passende metode.

Formålet med dette kapittelet er å presentere datainnsamlingsmetoden video-stimulated recall (VSR) gjennom å beskrive hva metoden innebærer, hva slags data den kan gi tilgang til og dermed hvordan den kan brukes i kvalitativ forskning. Først presenteres metodens bakgrunn, deretter sentrale elementer, fordeler og potensielle utfordringer. Datainnsamlingsprosessen eksemplifiseres med en steg-for-steg-guide, og det vises eksempler på typer data metoden kan gi tilgang til. I siste del vektlegges metodologiske vurderinger, og kapittelet ender i en oppsummering med refleksjoner og bruk av metoden i fremtidig forsknings- og utviklingsarbeid.

\section{Stimulated recall}

Termen stimulated recall (SR) har blitt brukt til å beskrive en variasjon av teknikker som involverer bruk av bilder, lyd- eller videoopptak av situasjoner. Opptakene brukes for å hjelpe deltakerne til å gjenkalle tankeprosesser i situasjonen (Calderhead, 1981). En av de første som dokumenterte bruk av stimulated recall, var Benjamin Bloom (1951, 1953). Den grunnleggende ideen bak metoden er at et subjekt kan settes i stand til å gjenoppleve en opprinnelig situasjon med livlighet og nøyaktighet hvis vedkommende presenteres for signaler eller stimuli fra den opprinnelige situasjonen (Bloom, 1953, s. 161). Bloom ønsket å utforske hvilken undervisningsform, forelesninger eller gruppediskusjoner, som gav studentene mest i utdanningsøyemed. Han var interessert i å undersøke studentenes tankeprosesser underveis i de ulike læringssituasjonene. Med lydopptak fra forelesninger og gruppediskusjoner som stimuli, bad han studentene skrive ned tankene de hadde underveis (Bloom, 1953). Bruken av stimulated recall ble utbredt da teacher thinking-forskningen utviklet 
seg mot slutten av 70-tallet, og tok opp i seg stimulated recall som en metode (Calderhead, 1981; Haglund, 2003).

Video-stimulated recall (VSR) som forskningsmetode baseres på videoobservasjon med påfølgende intervju. Utvalgte sekvenser fra orginalsituasjonen brukes til å støtte informantens gjenkalling av tanker i, og refleksjon om, situasjonen. Videosekvensen i seg selv er ikke det primære målet for analysen, da fokus er på refleksjonene om de valgte sekvensene (Nind, 2016).

Det finnes ikke én måte å gjennomføre en VSR-studie på. Metoden har tatt ulike former ut fra ulike forskningsinteresser i ulike forskningskontekster. Det finnes derfor ingen klar fremgangsmåte eller mal for hvordan man gjennomfører en VSR-studie. Det er det overordnende designet og problemstillingen for studien som vil være styrende. Samtidig må omfanget vurderes med tanke på ressursene man har til rådighet. I tidligere forskning har VSR blant annet blitt brukt i studier av klasseromspraksis og interaksjon (Gazdag et al., 2019; Plaut, 2006). Lærerens undervisning filmes, og i etterkant brukes video til å stimulere lærerens tankeprosesser og refleksjoner rundt for eksempel beslutningstaking. VSR har også bli brukt til å utforske beslutninger lærere tar når de planlegger og gjennomfører undervisning (Borko \& Shavelson, 1990). I lærerutdanningen har VSR blitt brukt som metode for å demonstrere refleksjonsmønstre og utvikle lærerstudenters refleksjonskompetanse (Borko et al., 1987; Husu et al., 2008; Toom et al., 2015). Metoden er også brukt for å undersøke elevers persepsjon av læring i klasserommet (Morgan, 2007), og til videoog/eller tekststimulerte intervjuer med elevgrupper om skrivehendelser de har vært med på (Bjørkvold, 2018). VSR kan også være et verdifullt verktøy i undersøkelser av andre sider ved læreres arbeid, for eksempel ulike former for lærersamarbeid knyttet til spesifikke fag eller tema.

Metoden i seg selv kan ikke sies å beskrive eller gi full tilgang til lærernes tanker (Calderhead, 1981). Den kan heller ikke stå på egne ben i en undersøkelse, men må kompletteres med andre undersøkningsmåter. Et VSR-intervju kan være strukturert eller ustrukturert, avhengig av forskningsspørsmålet. Hvis forskeren er ute etter alle tanker rundt en spesiell begivenhet, kan et ustrukturert intervju være passende (Pitkänen, 2015). En strukturert måte å designe et VSR-intervju på, kan være å legge 
vekt på såkalte kritiske hendelser. Kritiske hendelser defineres gjennom måten vi ser på en situasjon, og er en tolkning av en hendelses betydning. Det kan være utfordrende å velge ut sekvenser som representerer kritiske hendelser (Nind, 2016). Å betrakte noe som en kritisk hendelse er en vurdering man gjør, og grunnlaget for vurderingen er betydningen som tillegges hendelsen (Tripp, 2012).

Når man skal gjøre videoopptak, der sekvenser fra opptaket skal brukes som stimuli til refleksjon, er det flere hensyn å ta. Opptak av mennesker i deres aktiviteter bør være relativt lange, fra 30 minutter til en time. For de fleste typer aktiviteter vil det være tilstrekkelig for å fange bredden av aktiviteten (Dempsey, 2010).

Hvilken type spørsmål som brukes i stimulated recall er av overordnet viktighet. Spørsmålene rammes inn i et semi-strukturert intervju der lærerne blir sett på og behandlet som eksperter på egne tanker, refleksjoner og egen læring (Meier \& Vogt, 2015). Når man planlegger intervjuene, kan det være lurt å ha rom for åpne spørsmål som ikke er bare stimulirelatert (Pitkänen, 2015), da VSR-intervju ofte inneholder overraskende og uventede momenter (Dempsey, 2010). Dette betyr at «teorien» til informantene i studien må tas på alvor (Maxwell, 2013). Som forsker er det viktig å være oppmerksom på hvilke begrep informantene bruker.

Intervjuene anbefales gjennomført i kort tid etter videoopptak for best mulig nærhet i tid, og dermed best mulighet til gjenkalling av tanker og følelser (Lyle, 2003; Pitkänen, 2015).

\section{Fordeler med VSR}

Gjennom VSR-intervjuet diskuterer informantene faktiske handlinger og interaksjoner, og ikke handlinger de potensielt ikke husker nøyaktig. Ved hjelp av VSR får man også kastet lys på diskrepansen mellom det man som forsker ser på videoopptaket, og deltakernes forklaring av hva vi ser. Det bidrar til klargjøring av ulike aspekter og åpner opp for flere perspektiv på samme situasjon (Nind, 2016). Bruk av video støtter deltakernes refleksjon og kommunikasjon rundt handlinger, forståelser, meninger og konstruksjoner (Haw \& Hadfield, 2011). 
Å bruke video som et middel for å støtte deltakerne til å reflektere, kan knyttes til reflekterende praksis og den reflekterende praktikeren (Schön, 1987). Schön (1987) forstod refleksjon som en dialog mellom et problem og den som erfarer det. Ved å knytte refleksjon til utvikling av kvalitet, dvs. bli mer kompetent, peker han på potensialet som ligger i refleksjon (Schön, 1987, s. 31). En av nøkkelkonstruksjonene til teori om refleksjon, den refleksive feedback loop mellom individer og sammenhengene de inngår i, er sentral i VSR (Haw \& Hadfield, 2011; Winter \& Burroughs, 1989).

\section{Potensielle utfordringer med VSR}

VSR er en metode som, i likhet med mange andre metoder, må brukes med varsomhet. Potensielle utfordringer er knyttet til hukommelse, gjenkalling, timing og instruksjon. Derfor krever studier som bruker VSR nøye gjennomtenkte forskningsdesign for å unngå fallgruver (Mackey \& Gass, 2005). Det er flere faktorer som kan påvirke VSR-dataenes signifikans eller status (Calderhead, 1981; Mackey \& Gass, 2005). I dette kapittelet deles de inn fem sentrale faktorer: opplevelse av stress ved å se seg selv på video, tidsperspektiv, pålitelighet, taus kunnskap og forberedelse.

Det første er at det å se seg selv på videoopptak kan oppleves stressende, og informantene kan distraheres av sin egen fysiske tilstedeværelse på video (Calderhead, 1981). Disse reaksjonene er ikke nødvendigvis negative, og de fleste kommer over «sjokket» når de begynner å reflektere over innholdet. Ifølge Blikstad-Balaas (2017) er det behov for å gå ut over å diskutere om det er en effekt å utsettes for videoopptak, til å diskutere arten av denne effekten og de tilhørende kulturelle normene knyttet til å være «på video». Det kan tenkes at deltakerne ikke er vant til et «utenfra»-perspektiv på seg selv i denne settingen, og at den korte tiden fra videoopptak til intervju kan gjøre at de har «innenfra»-perspektivet friskt i minnet, og at dette bidrar til å fremkalle et visst ubehag. VSR er en avslørende metode som hjelper deltakerne å få et sant bilde av egen deltakelse, siden handlingen er tatt opp på video (Pitkänen, 2015).

Andre faktor er tidsperspektivet, og at VSR-data bør samles inn så snart som mulig etter at orginalsituasjonen fant sted. Dette er for å øke sannsynligheten for at datastrukturene som nås kommer fra korttidsminnet 
(Lyle, 2003; Pitkänen, 2015). Samtidig vil motivasjoner og refleksjoner informanter gir i ettertid ikke nøyaktig matche de tankene de hadde i møtet, og det er en viss fare for etter-rasjonalisering (Calderhead, 1981; Gass \& Mackey, 2000).

Den tredje faktoren er diskusjon av pålitelighet. En av kritikkene mot VSR det menneskelige behovet for å forklare og rasjonalisere. I ettertid av en situasjon kan man prøve å etter-rasjonalisere og forklare sine handlinger uten å relatere til hva man tenkte i situasjonen (Gass \& Mackey, 200o).

Læreres tause kunnskap er den fjerde faktoren (Calderhead, 1981). «Vi kan vite mer enn vi kan si», hevdet Polanyi (1983, min oversettelse). Etter flere års erfaring $i$ et yrke er det mye automatisert, subsidiær kunnskap som ikke er i fokal oppmerksomhet, for å bruke Polanyis begreper. Det at kunnskapen ikke er i fokal oppmerksomhet kan bety at deltakerne har et lavt bevissthetsnivå rundt denne kunnskapen, og at den ikke nødvendigvis kommer frem i form av eksplisitte utsagn. Vanligvis behøver ikke denne kunnskapen artikuleres, fordi et sosialt kollektiv i større eller mindre grad deler denne kunnskapen (Collins, 2010). Som sosialt kollektiv deler gruppen kunnskap som ikke «kommer opp på bordet». Den kan ligge der implisitt, og man kan få delvis tilgang til deler av den gjennom intervjuene. Deltakerne er ikke nødvendigvis trent i å sette ord på denne kunnskapen, og deler av den er kroppsliggjort og derav «taus».

Femte faktor handler om hvordan deltakerne forberedes på å kommentere og hvordan de blir instruert i å komme med sine kommentarer (Calderhead, 1981). Ifølge Gass og Mackey (2000) skal deltakerne være minimalt forberedt, men tilstrekkelig forberedt til å kunne gjennomføre prosedyren. Det har også sammenheng med forskningsspørsmålet. Dersom formålet er å hente tilbake tankene de hadde i situasjonen, kan spørsmål av typen «hva tenkte du da/da du sa X?», være passende (Ryan \& Gass, 2012). Hvis formålet er en mer «åpen» refleksjon der situasjonen er en igangsetter for refleksjon om andre områder i tilknytning til situasjonen, kan «hva tenker du?» være passende (Nind, 2016).

Nedenfor vil det presenteres eksempler på hvordan datainnsamlingsprosessen med VSR ble gjennomført i ett forskningsprosjekt. Hensikten med en detaljert gjennomgang av datainnsamlingsprosessen steg for steg, 
er å gi de som er nysgjerrig på, og vurderer å bruke metoden, et bilde av hvordan det kan gjøres.

\section{Video-stimulated recall i forskning av lærersamarbeid: Fem steg}

Det overordnede formålet for forskningsprosjektet der VSR ble brukt som en av flere datainnsamlingsmetoder, var å undersøke læreres samarbeid i team innenfor konteksten skolebasert utviklingsarbeid (SKU). Prosjektets empiriske data er fra fire lærerteam på 9. og 10. trinn ved fire ungdomsskoler i Norge.

Nedenfor presenteres en steg-for-steg-guide til gjennomføring av datainnsamling med video-stimulated recall: forberedelse og rekruttering av informanter; videoopptak av møtene; gjennomgang av videoopptak; planlegging av intervju; gjennomføring av intervju.

Gjennom de fem stegene gis en detaljert beskrivelse av datainnsamlingsprosessen slik den ble gjennomført i prosjektet. Den stegvise fremstillingen er inspirert av Dempsey (2010) og Pitkänen (2015), som har presentert fremgangsmåten for stimulated recall i studier av henholdsvis jazz jam-sesjoner og spillforskning. I dette kapittelet er fremstillingen knyttet til en studie av læreres samarbeid i team.

\section{Steg 1: Forberedelse og rekruttering av informanter}

Innledende samtaler med skoleledelsen og aktuelle lærerteam ble gjennomført. De fikk en orientering om prosjektet og hva deltakelse ville innebære for skolen, ledelsen og lærerne. Lærerne fikk vite at samarbeidet om utviklingsarbeid ville bli filmet, og at sekvenser fra opptaket ville brukes som utgangspunkt for intervju.

\section{Steg 2: Videoopptak av møtene}

Det ble gjennomført videoopptak av ett teammøte fra hver av de fire gruppene høsten 2018. Lærerne bekreftet i intervjuene at disse møtene var representative og typiske. Møtenes innhold varierte fra planlegging 
av undervisning i norsk og evaluering av elevenes mestring av grunnleggende ferdigheter, til analyse av resultatene av nasjonale prøver i lesing. Opptakene ble gjennomført ved å plassere et kamera på bordkanten. En trådløs mikrofon, med tilkobling til kameraet, ble plassert midt på bordet. Kameraet var innstilt på vidvinkel, og ble plassert slik at alle lærerne kom med, og mikrofonen nær nok til å få god lyd. Hensikten var å få så god dokumentasjon som mulig av aktiviteten som skulle studeres, og at det var det god kvalitet på lyd og bilde når det skulle velges sekvenser til intervju. Opptakene ble organisert med hensikt å fange interaksjonen $\mathrm{i}$ samarbeid i team der fire eller fem lærere satt rundt et bord. Det var ingen forsker til stede under møtene.

\section{Steg 3: Gjennomgang av videoopptak}

Videomaterialet ble gjennomgått kort tid etter opptaket av møtet. Innholdet ble grovtranskribert og hendelser og sekvenser markert. De utvalgte sekvensene ble gjennomgått sammen med medforsker, og sekvenser («kritiske hendelser») som skulle brukes i intervjuene ble valgt ut i fellesskap.

I tråd med problemstillingen fungerte «forslag til endringer» som «kritiske hendelser», og de var utgangspunkt for å utforske lærernes refleksjoner rundt teamarbeid (Halquist \& Musanti, 2010). Det måtte tenkes grundig igjennom hvilke sekvenser som ville være egnet til å stimulere informantenes tenkning og refleksjoner, og som kunne danne et grunnlag for å gjennomføre en diskusjon med forskeren (Nind, 2016). Vi vurderte at sekvensene som omhandlet «forslag til endringer» ville være i tråd med prosjektets overordnede mål, som var å undersøke lærersamarbeid innenfor rammene av skolebasert utviklingsarbeid. Det første kriteriet for utvelgelse var at læreren som ble intervjuet skulle være involvert i den pågående interaksjonen i sekvensen. Det andre kriteriet var at sekvensen inneholdt forslag til endring av problemer lærerne hadde lokalisert og definert som «dette må vi gjøre noe med». Hver av de valgte sekvensene varte i omtrent to minutter. I denne sammenhengen fungerte det som en hensiktsmessig lengde for stimuli til refleksjon. Forslagene ansporet lærernes utforskning og forhandlinger om hva de skulle gjøre videre, og utgjorde på den måten kritiske hendelser, i tråd med Tripps definisjon 
(2012). Lærere fra samme team fikk se de samme sekvensene, og intervjuene ble gjennomført innen to til fire dager etter det videoopptak, for best mulig nærhet i tid (Lyle, 2003; Pitkänen, 2015).

\section{Steg 4: Planlegging av intervju}

De valgte videosekvensene kan klippes ut ved hjelp av redigeringsverktøy, eller man kan markere tidsintervallene for hvert filmklipp manuelt. Hvert enkelt intervju ble planlagt etter klargjøring av videomaterialet. Det er ofte nyttig å gå tilbake til forskningsspørsmålene når man skal utarbeide intervjuguiden. Tidsrammen for hvert intervju var 30 minutter.

Det ble utviklet en intervjuguide som var relativt åpen, der man med utgangspunkt i lærernes egne ord og termer bad dem utdype og forklare nærmere. Samtidig etterstrebet forskeren å opptre på en måte som ikke gav inntrykk av at her er det «rette og gale» svar (Meier \& Vogt, 2015).

\section{Steg 5: Gjennomføring av intervju}

Som nevnt ovenfor, ble intervjuene gjennomført så kort tid som mulig etter opptaket av møtet. På grunn av tiden det tok å forberede intervjuene og praktiske hensyn (som lærernes arbeidsplaner, reisevei osv.), gikk det fra to til fire dager fra videoopptak til gjennomføring av intervju. Det ble gjort lydopptak av intervjuene.

Som innledning for å forberede informanten til intervjuet, introduserte forskeren følgende: «Ut fra møtet som ble filmet, der dere diskuterte x og x, har jeg plukket ut to sekvenser der du er med i en samtale som jeg gjerne vil høre mer om. Håper vi kan få en diskusjon rundt hva som skjer og hvorfor.» Bakgrunnen for denne formuleringen, var å prøve å trygge informanten i det som for han/henne var en ny og ukjent situasjon. Deltakerne skal være minimalt forberedt, men nok til å kunne gjennomføre prosedyren. De skal ikke trenes eller trigges i ekstra eller unødvendig kunnskap (Gass \& Mackey, 200o). Forsker prøvde å innta en åpen og anerkjennende holdning, og signalisere at her er det ikke rette og gale svar.

Nedenfor presenteres et utvalg data man kan få tilgang til gjennom VSR-intervju. 


\section{Eksempler på data fra VSR-intervju}

For å synliggjøre bredden av data VSR-intervju kan gi tilgang til, presenteres nedenfor et utvalg. Eksemplene deles inn i to hovedkategorier. Første kategori, loerernes beskrivelse av dagens praksis og elevenes loering, tar utgangspunkt i innholdet eller temaene lærerne samarbeider om og deres erkjennelser om problematiske sider ved eksisterende praksis. I sekvensene fra møtene kommer det forslag til endringer av praksis, og VSR åpner opp for lærernes refleksjoner og begrunnelser knyttet til forslagene. Lærerne reflekterer på ulike måter rundt forslagene til endring, og de stiller spørsmål ved og utforsker kritisk forslagene til endring (Lysberg \& Rønning, 2021). I den andre kategorien, om samarbeidet og egen rolle, vises det til et spenn i data fra gjenkalling av tanker og følelser lærerne hadde under møtet, kommentarer og refleksjoner om seg selv og om samarbeidet, til kommentarer om intervjusituasjonen.

Nedenfor (tabell 1) er en oversikt over den første av de to hovedkategoriene. Denne kategorien åpner opp for ny innsikt i lærernes erkjennelser om egen praksis og hva de må endre for å bedre kunne støtte elevenes læringsprosesser (Lysberg \& Rønning, 2021).

Tabell 1. Lærernes erkjennelser om dagens praksis og forslag til endring

\begin{tabular}{|c|c|c|}
\hline Innhold, hovedkategorier & Lærernes erkjennelser & Lærernes forslag til endring \\
\hline \multirow[t]{2}{*}{ Vurderingspraksis } & Vi gir for mange karakterer & $\begin{array}{l}\text { Redusere antall formelle } \\
\text { vurderingspunkter, gi mindre } \\
\text { karakterer }\end{array}$ \\
\hline & $\begin{array}{l}\text { Formativ vurdering støtter } \\
\text { elevenes læringsprosesser }\end{array}$ & $\begin{array}{l}\text { Mer vekt på formativ } \\
\text { vurdering og grad av } \\
\text { måloppnåelse }\end{array}$ \\
\hline Grunnleggende ferdigheter & $\begin{array}{l}\text { Sikre at elevene mestrer } \\
\text { grunnleggende ferdigheter }\end{array}$ & $\begin{array}{l}\text { Gjøre elevene bevisst på sine } \\
\text { læringsstrategier }\end{array}$ \\
\hline \multirow[t]{2}{*}{ Lese- og læringsstrategier } & $\begin{array}{l}\text { Bruken av leseplanen er for } \\
\text { usystematisk }\end{array}$ & $\begin{array}{l}\text { Mer systematisk bruk av } \\
\text { leseplanen }\end{array}$ \\
\hline & $\begin{array}{l}\text { Resultatene fra nasjonale } \\
\text { prøver i lesing avslørte at } \\
\text { elevene deres skåret dårlig på } \\
\text { nærlesing }\end{array}$ & $\begin{array}{l}\text { Lære elevene å lese på en } \\
\text { måte som støtter utvikling av } \\
\text { nærlesing }\end{array}$ \\
\hline Kildekritikk & $\begin{array}{l}\text { Elevene kommer med } \\
\text { påstander i tekstene som ikke } \\
\text { er troverdige; de kan vise til } \\
\text { hvor de har de fra }\end{array}$ & $\begin{array}{l}\text { Gjennomføre et } \\
\text { undervisningsopplegg om } \\
\text { kildekritikk }\end{array}$ \\
\hline
\end{tabular}


Eksempler fra den første kategorien i tabell 1 presenteres nedenfor; lærernes refleksjoner rundt erkjennelser om dagens vurderingspraksis og forslag til endring. De refererer til at de har noen uhensiktsmessige vurderingsrutiner; de har for mange vurderingspunkter og gir for mange karakterer.

C1: Mange elever stresser, jeg er ikke sikker på at det alltid er med på å utvikle dem så mye videre. Bare det å få selve tallkarakteren det er jo en ren sånn ytre motivasjon.

D1: [...] vi har innarbeidet oss noen rutiner, at vi tror at det må være så og så mange vurderingspunkter. Så vi prøver å bli flinkere på det og minne hverandre på at vi trenger ikke så mange vurderingspunkter. Selv om man ikke har en prøve eller en vurdering så betyr det jo ikke at det ikke er læring [...] Jeg tenker at det viktigste som skjer egentlig i timene, at man ser der og da hva de får til og hva de ikke får til, og at man går da direkte inn og veileder mens de er i prosessen.

A3: [...] hvordan kan vi vurdere dem [elevene] for å kanskje få ned antall vurderingspunkter, at norsk kan være en del av et annet fag og at vi slår i hop. Hvis vi får til sånne større samtaler og diskusjoner, at de kan være grundig nok så kanskje vi får ned. Og vi er jo ikke i tvil om at skal vi få til denne dybdelæringen og få god nok tid til det så må vi jo tenke, da hjelper det jo ikke å ha 60 min KRLE i uka for eksempel. Da må det henge sammen med noe.

B1: Jeg kan følge dem, jeg kan gi dem en fremovermelding mens de holder på. For jeg tenker at det er jo vi som er, vi som jobber her som er også utdannet innenfor dette, sånn at det er litt urettferdig å sende elever hjem med forskjellig [...] foreldrene, altså med tanke på hva de har å bidra med.

I transkriptene fra intervjuene ser vi at temaet vurderingspraksis er sentralt i lærernes arbeid ved at de på tvers av team og skoler reflekterer og vurderer kritisk problematiske sider ved dagens vurderingspraksis. Ved hjelp av VSR får vi ny innsikt i lærernes pedagogiske begrunnelser for endringer i vurderingspraksis. Transkriptene fra VSR-intervjuene viser at lærere begrunner forslag til endringer i både erfaringsbasert kunnskap, teori og forskningsbasert kunnskap (Lysberg \& Rusk, 2021). 
Den andre hovedkategorien data, om samarbeidet og egen rolle (tabell 2), gav ny innsikt i tanker og følelser lærerne hadde under møtet, deres kommentarer og refleksjoner om seg selv, egen rolle, egen læring, samarbeidsprosessen, verdier og kommentarer om intervjusituasjonen. I tabellen nedenfor presenteres eksempler fra et bredt spekter av typer data man kan få tilgang til gjennom bruk av VSR-intervju, noe som viser frem spennet i muligheter. Kategoriene som presenteres tar utgangspunkt i tabell 2, og det gis eksempler på et avgrenset utvalg data.

Tabell 2. Lærernes refleksjoner om samarbeidet og egen rolle

\begin{tabular}{ll}
\hline Gjenkjenning & Kommentarer og refleksjoner om \\
\hline Gjenkjenning av tanker og følelser de hadde i & seg selv \\
situasjonen, stimulert av video & egen rolle \\
& egen læring \\
& verdier \\
& samarbeidsprosessen \\
& intervjusituasjonen \\
\hline
\end{tabular}

Den første inkluderer ytringer der lærerne gjenkjenner de tankene og følelsene som oppstod i henne/han i situasjonen.

C2: $\quad$ For jeg nevnte det i sted, jeg kom på det når jeg så videoen. [...] Jeg satt og var redd for at jeg skulle være negativ når jeg så meg selv, fordi at jeg husket at jeg hadde disse, og jeg ser det på kroppsspråket. Åh, jeg får helt angst altså! Men det var fordi at jeg blir så frustrert [...] altså hvis jeg skal snakke om meg, altså av andre oppfattes som sånn frustrert eller «dette her gidder ikke jeg», eller noe sånt. Men det tror jeg det er rom for det. For det var det jeg bare kjente med en gang: «Herregud, at jeg har sagt noe som jeg har tenkt?»

C1: Jeg tror ikke jeg sa det veldig tydelig, men inni meg så tenkte jeg at det er fint om de ikke får lov å velge tekst ... eller jeg velger dikt selv i dette her tilfellet. Og det havnet jo de andre på. Men jeg tror ikke jeg påvirket den avgjørelsen så mye egentlig. Så da tenkte jeg bare stille inni meg at det var bra.

Andre eksempel er kommentarer og refleksjoner om seg selv. Det inkluderer utsagn hvor det blir nevnt en observasjon eller evaluering som han/ 
hun gjør angående sin egen oppførsel når han/hun ser videosekvensen. I det tredje eksempelet, som omhandler egen rolle $i$ møtet, nevner lærerne en observasjon eller evaluering som han/hun gjør angående egen rolle og tanker om hvordan han/hun oppleves av andre:

D3: Jeg oppleves veldig ofte uenig. Jeg føler meg ennå som ny, så jeg er litt sånn. Du ser det på møtet, det blir veldig tydelig når det blir filmet at jeg er litt sånn, jeg holder meg litt i bakgrunnen for at her sitter noen andre som har masse erfaring. Så jeg sitter egentlig bare og suger litt til meg ennå føler jeg.

D4: Men så jeg må jo stille liksom spørsmål etter spørsmål til ho Y, og da er det jo litt sånn veldig kritisk. Men så forstår jeg jo. Ho X også henger seg jo på, og hun vil jo ha dette her i sin klasse [...] Jeg føler jo at jeg prater mye, og det vet jeg jo at jeg gjør. Jeg føler jo at jeg var litt sånn kritisk kanskje, litt sånn, litt i forsvar eller jeg vet ikke.

Fjerde eksempel inneholder kommentarer og refleksjoner over hvordan samarbeidet i teammøter bidrar til deres egen loering, via deres økte kunnskap og bevissthet om elevenes læring. Femte eksempel inneholder kommentarer og refleksjoner om samarbeidsprosessen hvor læreren kommenterer en observasjon som han/hun gjør seg angående samarbeidet når han/hun ser videosekvensen. Eksempel seks inneholder kommentarer og refleksjoner rundt verdier. De stiller spørsmål ved møtenes innhold og refererer til elevene som «hele mennesker», samt at de som lærere utgjør en forskjell for elevene:

B2: Det er greit at jeg skal undervise, jeg skal lære dem noe. Men jeg vet ikke om det er halvparten av jobben [ler], det er så mye annet, ikke sant og jeg bruker å tenke at det vi som er en forskjell for dem, for selv om det er tungt mange ganger, så må vi være der.

B4: Men jeg synes jo også det har en side som vi kanskje glemmer lite grann, og det blir veldig isolert på grunnleggende ferdigheter. Og det menneskelige ... altså, vi må huske på at dette er mennesker som sitter på alle disse stolene [...] det er ikke bestandig at de egenskapene blir vektlagt like mye. Og for de som gjør det godt på skolen og alt sånn så er det kanskje ikke så viktig, men kanskje for de som sliter aller mest så trenger de å høre at livet er mer enn bare disse karakterene tenker jeg. 
Det syvende eksempelet på data består av kommentarer og refleksjoner om intervjusituasjonen, og inkluderer utsagn hvor læreren nevner en tanke, følelse eller kroppslig følelse som vekkes når han/hun ser episoden eller deltar i intervjusituasjonen:

B4: Og jeg kjenner at jeg blir litt sånn anspent, jeg får ikke helt fram, jeg blir litt sånn forknytt når jeg skal sitte og prate her.

Som vist i datapresentasjonen ovenfor, så kan man få tilgang til et bredt spekter av data når man bruker video til å stimulere refleksjoner om konkrete situasjoner. Her har det blitt vist eksempler på hvordan lærerne reflekterer over innholdet og egen rolle i samarbeidet. Det vil være studiens formål og forskningsspørsmål som styrer hvilken type data man er ute etter, og dermed hva man går nærmere inn på i analysen.

\section{Metodologiske vurderinger}

Hva er det egentlig man undersøker når man gjennomfører VSR på denne måten? Hvilke typer «feil» kan oppstå i løpet av datainnsamlingen? Videosekvensene som er valgt ut til VSR-intervju er ikke orginalsituasjonen, det er en rekonstruksjon. Denne rekonstruksjonen åpner for refleksjon og metaanalyse som gir mulighet til innsikt i tanker om orginalsituasjonen, som vist ovenfor.

Tilnærmingen VSR kan bidra til forståelse av hva individuelle deltakere anser som viktig, og hvilke forklaringer de prøver å formidle til andre (Dempsey, 2010). Lydopptak av VSR bidro til å utvide forståelsen av situasjonen ut over den man får tilgang til ved å kun å se på videoopptaket (Haw \& Hadfield, 2011). VSR bringer informantene nærmere situasjonene som fant sted, og gir dem mulighet til å lytte til og se på seg selv fra utsiden, samtidig som de har med seg et innsideperspektiv (Dempsey, 2010). Deltakerne forklarer hva som skjer under forutsetning av at det er ukjent for utenforstående, og de gir eksplisitte forklaringer for forskeren (Pomerantz, 2005). Bruk av VSR hjelper med å utlede tolkninger, mål og bekymringer som deltakerne kan ha orientert seg mot da opptaket ble gjort. Deltakernes refleksjoner kan forklare elementer ved den aktuelle situasjonen som ellers kan være utilgjengelige for forskeren (Pomerantz, 
2005), selv om refleksjonene deres, som nevnt ovenfor, ikke er identiske med hva de tenkte i situasjonen.

\section{Oppsummering}

I dette kapittelet presenteres ett eksempel på hvordan datainnsamlingsmetoden video-stimulated recall (VSR) kan gjennomføres. En beskrivelse av metoden steg for steg ender opp i eksempler på typer data den kan gi tilgang til. I disse dataene ligger det muligheter for ny innsikt. Dette diskuteres nedenfor ved å se på muligheter for bruk av metoden i fremtidig forsknings- og utviklingsarbeid.

Hvilken type forskning og utviklingsarbeid kan VSR være egnet for, og hvilke typer data får man tilgang til ved å bruke denne metoden? Som vist i dataeksemplene ovenfor, innebærer VSR at informantene gis mulighet til å forklare og reflektere fra sitt «innside»-perspektiv rundt det som skjer i autentiske situasjoner. Når informantene ser seg selv på video, kan den metodiske tilnærmingen bidra til at det bringes frem noe ved situasjoner som bevisst eller ubevisst har «plaget» informantene (Lysberg \& Rønning, 2021). Videoen bringer dem tilbake til situasjonene de deltok i, og stimulerer dem til å huske tanker om, og refleksjoner over, situasjonen (Dewey, 1991; Webster-Wright, 2009). I ett av dataeksemplene ovenfor, i kategorien om samarbeidet og egen rolle, ser vi hvordan lærerne gjenkjenner tankene og følelsene som oppstod i ham/henne i situasjonen. Det vises også til data der lærerne kommenterer og reflekterer over hvordan samarbeidet i teammøter bidrar til deres egen loering. Denne eksplisitte bevisstheten og kunnskapen kan være et viktig bidrag til systematisk innsats mot endring og utvikling (Tomlinson et al., 2010; Webster-Wright, 2009). Webster-Wright (2009) karakteriserer dette som «autentisk profesjonell læring».

Å snakke med lærerne individuelt endret måten vi som forskere oppfattet møtene på. Når vi via VSR fikk tilgang til perspektivet til informanter som har deltatt i samme situasjon, bidro metoden med tilgang til beskrivelser og refleksjoner som utgjør «lag på lag» av forståelser og forklaringer av hva som skjedde i en gitt situasjon. Samlet sett utgjør de ulike forståelsene et skarpere fokus, noe som gir oss som forskere grundig innsikt i den aktuelle situasjonen. Samtidig ble det synliggjort at lærerne 
har noen felles refleksjoner, men at de også resonnerer og reflekterer ulikt rundt de samme situasjonene, noe som muliggjør utforsking av samme situasjon fra flere perspektiver. Metoden gir mulighet til innsikt i informantenes refleksjoner og resonnementer rundt for eksempel beslutninger (Lysberg \& Rønning, 2021). Bruk av VSR som tilnærming i forskning kan på denne måten være et verdifullt verktøy i å hjelpe forskere med å finne ut $h$ vorfor, samtidig som det er en viss risiko for etter-rasjonalisering.

Mer åpne tilnærminger til VSR, der man gir deltakeren en mye større grad av kontroll med relativt lite innspill fra forskeren, er også mulig. Hvis deltakerne ikke blir ledet $\mathrm{i}$ å fokusere, vil gjenkallingen og dataene være mindre utsatt for forskerinnblanding (Gass \& Mackey, 20oo; Lyle, 2003). Ett eksempel kan være at deltakeren blir bedt om å gi en løpende kommentar til videoopptaket ved å «tenke høyt». En slik mulighet, der deltakerne velger og kontrollerer stimulusepisoder, vil redusere sannsynligheten for forskerinnblanding, men ustrukturerte situasjoner resulterer ikke alltid i nyttige data (Gass \& Mackey, 20oo). I forskningsprosjektet ovenfor valgte vi en strukturert tilnærming, der vi som forskere på forhånd valgte ut videosekvenser som inneholdt forslag til endringer, i tråd med problemstillingen. Hvorvidt man skal gjennomføre åpne eller mer kontrollerte tilnærminger, beror på hva man slags data man er ute etter.

Som vist ovenfor, kan VSR også hjelpe forskere med å svare på grunnleggende spørsmål om interaksjon. Det har for eksempel blitt presentert data der lærerne gjenkjenner tankene og følelsene som oppstår i dem i situasjonen, som i tilfellet der en av informantene $\left(\mathrm{C}_{2}\right)$ gjenkalte sine egne frustrerte følelser da han/hun så på sitt eget kroppsspråk. Å studere ulike typer interaksjoner ved hjelp av VSR kan bidra til innsikt i sentrale elementer i konteksten som påvirker interaksjoner, eller at man oppdager hva slags tenking som styrer folks deltakelse i interaksjoner, noe som eksemplene på typer av data ovenfor viser. Det kan også være mange andre domenespesifikke spørsmål metoden kan hjelpe forskere å svare på. Alle som er interessert i detaljene i interaksjoner, og deltakernes ulike perspektiv, anbefales å vurdere bruk av denne metoden. Til tross for at det krever engasjement fra informantenes side å bli konfrontert med sine egne ord og handlinger, vil man som forsker få tilgang til interessante 
data ved å bruke VSR. Ettersom audiovisuelt opptaksutstyr med høy kvalitet blir stadig mer overkommelig og lite påtrengende, kan forskere som er interessert $\mathrm{i}$ en rekke situasjoner finne at fordelene med VSR oppveier kostnadene (Dempsey, 2010).

VSR kan også brukes i utviklingsarbeid, eksempelvis ved å inkludere fagfellevurdering av videoer og bruker det som stimulus for kritisk utforsking og refleksjon i grupper. VSR kan være aktuelt som verktøy i profesjonsutdanninger. For eksempel kan videoopptak av eksperter knyttes til interaktive videopakker som illustrerer beslutningsstrategier i komplekse situasjoner (Lyle, 2003).

I dette kapittelet er det synliggjort hvordan video er et kraftfullt verktøy for å stimulere refleksjon over forhold som ellers ofte forblir uavdekket. VSR kan derfor være et nyttig verktøy for faglig utvikling i en rekke profesjoner. Det er imidlertid viktig å erkjenne at metoden er ressurskrevende, og at den gjennomføres med høy bevissthet om metodens styrker og begrensninger.

\section{Referanser}

Bjørkvold, T. (2018). Å skape behov for skriving. Literacypraksiser hos elever som forsker [Doktorgradsavhandling, OsloMet - storbyuniversitetet]. ODA. https://hdl.handle.net/10642/6362

Blikstad-Balas, M. (2017). Key challenges of using video when investigating social practices in education: Contextualization, magnification, and representation. International Journal of Research \& Method in Education, 40(5), 511-523. https://doi.org/10.1080/1743727X.2016.1181162

Bloom, B. S. (1951). Some results of a study of conscious thought processes in classroom situations [Paperpresentasjon]. The American Psychological Association Meeting, Chicago, Illinois.

Bloom, B. S. (1953). Thought-processes in lectures and discussions. The Journal of General Education, 7(3), 160-169.

Borko, H., Lalik, R. \& Tomchin, E. (1987). Student teachers' understandings of successful and unsuccessful teaching. Teaching and Teacher Education, 3(2), 77-90. https://doi.org/10.1016/0742-051X(87)90009-6

Borko, H. \& Shavelson, R. J. (1990). Teacher decision making. I B. F. Jones \& L. Idol (Red.), Dimensions of thinking and cognitive instruction (s. 311-346). Erlbaum. 
Calderhead, J. (1981). Stimulated recall: A method for research on teaching. British Journal of Educational Psychology, 51(2), 211-217. https://doi.org/10.1111/j.20448279.1981.tbo2474.x

Collins, H. (2010). Tacit and explicit knowledge. University of Chicago Press.

Dempsey, N. P. (2010). Stimulated recall interviews in ethnography. Qualitative Sociology, 33(3), 349-367. https://doi.org/10.1007/s11133-010-9157-X

Dewey, J. (1991). How we think. Prometheus Books.

Gass, S. M. \& Mackey, A. (200o). Stimulated recall methodology in second language research. Routledge. https://doi.org/10.4324/9781410606006

Gazdag, E., Nagy, K. \& Szivák, J. (2019). «I spy with my little eyes ...» The use of video stimulated recall methodology in teacher training: The exploration of aims, goals and methodological characteristics of VSR methodology through systematic literature review. International Journal of Educational Research, 95, 60-75. https://doi.org/10.1016/j.ijer.2019.02.015

Haglund, B. (2003). «Stimulated recall»: Några anteckningar om en metod att generera data. Pedagogisk Forskning i Sverige, 8(3), 145-157. https:/gup.ub.gu.se/ publication $/ 102848$

Halquist, D. \& Musanti, S. I. (2010). Critical incidents and reflection: Turning points that challenge the researcher and create opportunities for knowing. International Journal of Qualitative Studies in Education, 23(4), 449-461. https://doi.org/ 10.1080/09518398.2010.492811

Haw, K. \& Hadfield, M. (2011). Video in social science research: Functions and forms. Taylor \& Francis.

Husu, J., Toom, A. \& Patrikainen, S. (2008). Guided reflection as a means to demonstrate and develop student teachers' reflective competencies. Reflective Practice, 9(1), 37-51. https://doi.org/10.1080/14623940701816642

Lyle, J. (2003). Stimulated recall: A report on its use in naturalistic research. British Educational Research Journal, 29(6), 861-878. https://doi.org/10.1080/01411920 32000137349

Lysberg, J. \& Rusk, F. (2021). Teachers' decision-making processes during teamwork [Under utarbeidelse]. Education Inquiry.

Lysberg, J. \& Rønning, W. (2021). Teachers' reflections on proposals for change in situated teamwork. Reflective Practice, 22(4) 1-15. https://doi.org/10.1080/ 14623943.2021.1915267

Mackey, A. \& Gass, S. M. (2005). Second language research: Methodology and design. Erlbaum. https://doi.org/10.4324/9781410612564

Maxwell, J. A. (2013). Qualitative research design: An interactive approach (Bd. 41). Sage publications. 
Meier, A. M. \& Vogt, F. (2015). The potential of stimulated recall for investigating self-regulation processes in inquiry learning with primary school students. Perspectives in Science, 5, 45-53. https://doi.org/10.1016/j.pisc.2015.08.001

Morgan, A. (2007). Using video-stimulated recall to understand young children's perceptions of learning in classroom settings. European Early Childhood Education Research Journal, 15(2), 213-226.

Nind, M. (2016). Video stimulated recall, reflection and dialogue: Introduction to the method. National Centre for Research Methods. https://www.ncrm.ac.uk/ resources/online/video_stimulated_research_methods/

Pitkänen, J. (2015). Studying thoughts: Stimulated recall as a game research method. I P. Lankoski \& S. Björk (Red.), Game research methods (s. 117-132). ETC Press.

Plaut, S. (2006). «I just don't get it»: Teachers' and students' conceptions of confusion and implications for teaching and learning in the high school English classroom. Curriculum Inquiry, 36(4), 391-421. https://doi.org/10.1111/j.1467873X.2006.00364.X

Polanyi, M. (1983). The tacit dimension. Peter Smith.

Pomerantz, A. (2005). Using participants' video stimulated comments to complement analyses of interactional practices. I H. T. Molder \& J. Potter (Red.), Conversation and cognition (s. 93-113). Cambridge University Press.

Ryan, J. \& Gass, S. (2012). Stimulated recall. I R. Barnard \& A. Burns (Red.), Researching language teacher cognition and practice: International case studies (s. 144-161). https://doi.org/10.21832/9781847697912-010

Schön, D. A. (1987). Educating the reflective practitioner: Toward a new design for teaching and learning in professions. Jossey-Bass.

Tomlinson, P. D., Hobson, A. J. \& Malderez, A. (2010). Mentoring in teacher education. I B. P. McGaw, P. L. Peterson \& E. Baker (Red.), International encyclopedia of education (3. utg., s. 749-756). Elsevier.

Toom, A., Husu, J. \& Patrikainen, S. (2015). Student teachers' patterns of reflection in the context of teaching practice. European Journal of Teacher Education, 38(3), 320-340. https://doi.org/10.1080/02619768.2014.943731

Tripp, D. (2012). Critical incidents in teaching: Developing professional judgement. Routledge.

Webster-Wright, A. (2009). Reframing professional development through understanding authentic professional learning. Review of Educational Research, 79(2), 702-739. https://doi.org/10.3102/0034654308330970

Winter, R. \& Burroughs, S. (1989). Learning from experience: Principles and practice in action-research. Falmer Press. 



\title{
Why so toxic? Spelarjargong och stötande språkbruk - skärminspelningar av e-sport i en pedagogisk kontext
}

\author{
Matilda Ståhl \\ Åbo Akademi University, Vaasa, Finland
}

\begin{abstract}
As growing societal phenomena, esports and gaming is gaining more interest and visibility in educational contexts. However, online game culture often involves offensive language as an established player jargon. Therefore, employing games in educational settings may be challenging. Here, player jargon is exemplified from an ethno-case study in collaboration with students at an esports program in Finland. Seven students (identifying as male, aged 17-18) from two different teams regularly shared screen recordings of matches of the multiplayer game CounterStrike: Global Offensive. The aim of the chapter is twofold: a) to analyse and discuss how player jargon is employed in esports within an educational context and b) to discuss how video research, here through screen recordings, facilitates analysis of player jargon within a new educational field of research. The screen recordings, administered by the participants themselves, included the team internal voice chat, thereby offering an intimate participant perspective on player jargon in online game culture. Through this, the researcher gains repeated access into a space no outsider otherwise has access to as the internal voice chat solely includes invited players. The data, and analysis, show that the language use, at times homophobic and/or misogynistic, becomes particularly problematic when esports and education meet, since offensive language defies educational principles of equity. Nevertheless, what would be a better place to address this in-game culture than in educational contexts?
\end{abstract}

Keywords: esports, player jargon, education, screen recordings, ethno-case study, video research 


\section{Inledning}

Digitala spel utgör idag en central del av barns och ungas liv och inom spelvärlden finns stor variation på genrer med olika fokus (Gee, 2007). Spelande är idag en populär aktivitet såväl internationellt som i Finland, där både de digitala spelens popularitet och intresset för elektronisk sport, dvs. e-sport, ökat (Kinnunen et al, 2018; Kinnunen et al, 2020). Såväl pedagogiskt som kommersiellt utvecklade spel kan erbjuda spelaren möjlighet till lärande och utveckling (se exempelvis Barr, 2019). Implementeringen av spel har därmed väckt stort intresse inom utbildningsforskningen, även om det finns ett behov av att bättre förstå kommersiella spel ur ett pedagogiskt perspektiv (Barr, 2019). Tävlingsinriktat spelande förutsätter, bland annat, fungerande samarbete och god kommunikationsförmåga (Rusk, Ståhl \& Silseth, 2020, 2021; Rusk \& Ståhl, 2020). Men för att kunna föra en informerad diskussion om pedagogik och spel behövs empirisk forskning på området (Gee, 2007).

I det här kapitlet kommer jag att fokusera på multiplayerspel, vilket innebär att spela online tillsammans med andra. Här exemplifieras multiplayerspel av ett specifikt spel, Counter Strike: Global Offensive (CS:GO), inom såväl ett pedagogiskt sammanhang som en tävlingskontext då deltagarna studerar vid ett e-sportprogram vid ett yrkesinstitut i Finland Online multiplayerspel är präglade av ett hårt språkbruk som är så väletablerat att det utgör en så kallad spelarjargong (Pulos, 2013). Spelarjargongen utgör normen i multiplayerspel, vilket innebär att en klar konflikt uppstår då e-sport möter pedagogiska värderingar om jämlikhet och demokrati (Ståhl \& Rusk, 2020). Spelarjargong är ett värdeladdat ämne som intervjustudier kan erbjuda viktiga perspektiv på, men där svaren riskerar att snarare reflektera det deltagarna tror att forskaren vill höra än hur spelarjargongen verkligen görs inom spelvärlden. Skärminspelningar utgör ett möjligt verktyg för att fånga den situerade spelvärlden och spelarjargongen ur ett deltagarperspektiv (Russell \& Barley, 2020). Syftet med kapitlet är tudelat: å ena sidan synliggörs användningen av spelarjargong inom e-sport i en pedagogisk kontext. $\AA ̊$ andra sidan erbjuder kapitlet även en metodologisk diskussion kring skärminspelningar och hur videoforskning (här genom skärminspelningar genomförda 2017-2018) möjliggör analys av spelarjargong inom 
ett nytt pedagogiskt forskningsfält. Skärminspelningar kan erbjuda insyn i samtida kontexter med relevans för pedagogisk forskning och kan stödja pedagogerna i deras verksamhet.

\section{Spelarjargong och teknomaskulinitet inom spelarkulturen online}

Datorspel har traditionellt varit en mansdominerad arena med begränsad kvinnlig representation bland såväl karaktärer som spelare, även om antalet kvinnliga spelare ökat (N. Taylor \& Voorhees, 2018). Idag är det är lika vanligt bland finländska kvinnor som män att spela, men att män tenderar att vara mer aktiva spelare (Kinnunen et al., 2018). Fortsättningsvis råder ändå segregering i spelvärlden, också på professionell nivå. Inom e-sport är prispotterna för manliga spelare högre och kvinnliga spelare glamoriseras med fokus på deras könstillhörighet framom deras spelande (T. L. Taylor, 2009). Kvinnliga spelares tillgång till spelarenor tenderar att vara mer generös i amatörsammanhang men betydligt mer restriktiv ju mer tävlingsorienterad verksamheten blir (Sveningsson, 2012). Dessutom tenderar kvinnliga spelare online att gradera sina färdigheter som sämre än deras manliga medspelares, även om det är engagemang samt antalet spelade timmar och inte könstillhörighet som avgör spelarens kompetens (Ratan et al., 2015).

Rasism förekommer i spelvärlden online (Gray, 2020; Nakamura, 2009) och dessutom tycks det finnas ett bestående ideal för den kompetenta e-sportspelaren; en ung vit heterosexuell cis-man ${ }^{1}$ som är tävlingsfokuserad (Witkowski, 2018). Rådande genusnormer begränsar kopplingen mellan teknisk kompetens, digitalt spelande och femininitet (Harvey, 2015) och samtida diskurser framhåller spelande och teknologi som en maskulin kompetens, eller teknomaskulinitet. I en kontext där bemästrandet av tekniskt kunnande hyllas (Maloney, Roberts \& Graham, 2019), utgör teknomaskulinitet den hegemoniska maskuliniteten inom spelvärldens alla nivåer och därmed nedvärderas icke-maskulina drag

1 För en cis-person, till skillnad från exempelvis en transperson, överensstämmer hens biologiska kön med hens upplevda kön. 
(Johnson, 2018). Samtida forskare har dock noterat att rådande maskulinitetsnormer ifrågasätts och till och med utmanas såväl i samhället i stort som inom spelvärlden. Det innebär däremot inte nödvändigtvis att vi är på väg till ett utopistiskt samhälle utan genusproblematik, utan snarare att det uppstår två parallella typer av hegemonisk maskulinitet; en inkluderande och en konservativ (Maloney et al., 2019). Även professionella spelare av CS:GO kan upprätthålla uttryck för en militariserad maskulinitet, vilket Voorhees och Orlando (2018) noterade att det direkt hängde samman med deras roller inom spelet. Exempelvis konstruerade "the AWPer" (spelaren som bär vapnet med kikarsikte) en personlighet som hård, effektiv och fåordig, som är "för tuff för ord" (Voorhees \& Orlando, 2018, s. 218).

Trots att tävlan i spelvärlden påstås vara fokuserat på skicklighet framom könstillhörighet och/eller etnicitet noterade Harper (2013) att diskursen präglas av fördomar: kvinnor anses per automatik vara sämre spelare, medan asiatiska spelare anses ha biologiska fördelar. Fördomar från världen utanför spelen är även närvarande online då en del spelare använder sig av nedsättande ord för sexuella minoriteter som skällsord och därmed upprätthåller en negativ syn på HBTQIA+ personer även inom spelvärlden. Den här typen av praktiker stödjer heteronormativitet i spel och används så högfrekvent att det kan anses vara ett "gamer lingo", d.v.s. spelarjargong (Pulos, 2013) och kan ses som ett "spel i spelet” (Vossen, 2018). Idealet av en manlig spelare online är så djupt rotat att till och med i explicit HBTQIA+ inkluderande grupper antas spelare man inte känner vara (homosexuella) män (Sundén, 2012).

\section{Skärminspelningar som videodata}

Den här studien positioneras som en etno-fallstudie (ethno-case study, Parker-Jenkins, 2018): en kvalitativ fallstudie informerad av etnografiska metoder. Inom fallstudiemetodologin ligger fokus på en fördjupad förståelse av ett fenomen genom ett specifikt fall (Schwandt \& Gates, 2018). Gränsen mellan etnografi och fallstudie kan vara svårdefinierbar då metodologierna delvis är överlappande och båda fokuserar på ett deltagarperspektiv. Inom båda används varierande datainsamlingsformer, 
men medan fallstudier kan vara mer kortvariga lägger man inom etnografin vikt vid mer långvarig insyn i det beforskade fältet (Hammersley, 2018; Parker-Jenkins, 2018). Vidare kan tillgång till fältet begränsas av en rad orsaker, såsom exempelvis forskarens ålder och könstillhörighet. Den här typen av 'annorlundaskap' kan begränsa insynen i fältet och därför har även erkända speletnografer så som T. L. Taylor (2012), valt att inte rapportera somliga studier som etnografier. Diskussionen om tillgång till fältet fortsätter i avsnitt 5.2 och i fortsättningen diskuterar jag den i relation till etnografisk forskning.

Digital eller virtuell etnografi (se exempelvis Beaulieu, 2004; Boellstorff et al., 2012; Pink et al., 2016; Shumar \& Madison, 2013) innebär ett perspektiv på hur man kan använda etnografiska metoder med, genom och i miljöer formade av digitala medier. För att kunna beforska en samtid i förändring behöver metoderna utvecklas i takt med samhället. Ett sådant exempel är skärminspelningar på online multiplayerspel. Skärminspelningar, framförallt för att nå ett deltagarperspektiv, är en tämligen ny metod inom pedagogisk forskning och metodologiska diskussioner på temat är få (Sahlström et al., 2019 och Paakkari, 2020 tillhör undantagen). Det här kapitlet framför ett sådant metodologiskt perspektiv och fokuserar på hur skärminspelningar som videodata erbjuder dokumentation och insyn i rum där jag som forskare annars begränsas av mitt "annorlundaskap".

\section{Studiens kontext}

Spelserien Counter-Strike har bidragit till att forma den alltmer professionaliserade spelvärlden (Rambusch et al., 2007). Spelserien är fortsättningsvis populär i Finland; sjunde på listan av de mest populära spelen 2018 och femte år 2020 (Kinnunen et al., 2018; Kinnunen et al., 2020). I en CS:GO-match tävlar två lag (á 5 spelare) mot varandra och det lag som vinner flest rundor vinner matchen. Matcher varar vanligtvis 20-45 minuter. Laget spelar antingen som antiterrotister eller terrorister och byter sedan roll halvvägs. Laget kan antingen vinna rundan genom att uppnå sitt mål eller hindra motståndarlaget från att uppnå deras, och målet varierar enligt den karta man valt att spela den matchen. Exempelvis kan 
målet vara att eliminera samtliga motståndare varje runda, och då får den eliminerade spelaren vänta till följande runda.

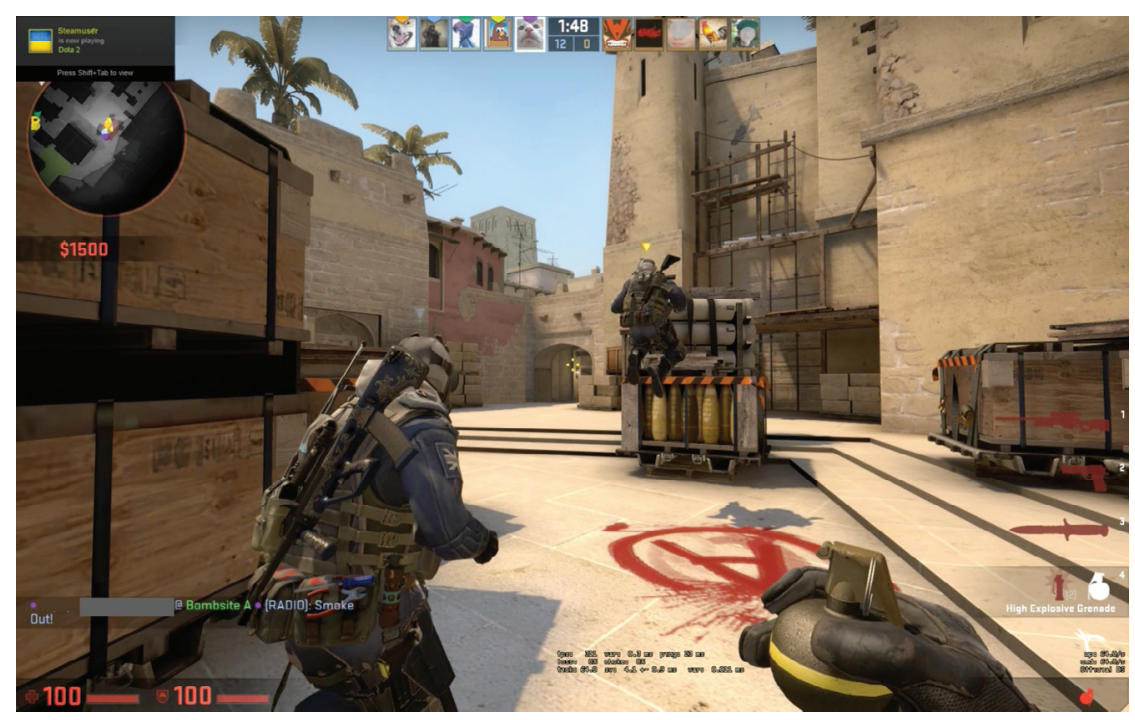

Figur 1. Utdrag från skärminspelning ur spelet Counter-Strike: Global Offensive.

Genom skärminspelningarna framgår tre nivåer av kommunikation, varav två erbjuds av spelet. Den första, textbaserad chatt (TBC), har två olika format: allchatt (meddelanden når alla spelare) och teamchatt (meddelanden når enbart det egna laget). Den andra, intern röstbaserad chatt (internal voice chat, IVC), når enbart det egna laget och kan uppfattas som otymplig då spelaren måste hålla in en tangent för varje taltur. Därför använder många spelare en extern röstbaserad chatt (external voice chat, EVC) för att prata med sina vänner i spelet. I det aktuella materialet använder lagen varsin Discord-kanal för att fritt kunna kommunicera inom gruppen utan att behöva hålla in en tangent för varje taltur. Under de matcher där inte alla lagmedlemmar är på plats tilldelas gruppen en tillfällig medspelare. Tillfälliga medspelare hänvisas ofta till som en "random" och har i regel inte tillträde till Discord-kanalen.

I huvudsak används EVC för spelintern kommunikation inom laget, med några undantag. Från och med nu hänvisar jag till spelare från någotdera lagen som lagmedlemmar och tillfälligt tilldelade okända spelare som medspelare. 


\section{Datainsamling och urval}

Studiens deltagare anmälde sig som frivilliga att delta genom en lärare. Inledningsvis var det sex deltagare, men som lagmedlem i lag 1 (L1) valde John att delta under studiens sista fas. Deltagarna genomförde själva skärminspelningarna och delade kontinuerligt matcher (se tabell 1, totalt ca nio timmar skärminspelningsdata, fem matcher per lag) genom en säker fildelningsservice. Deltagarna fick instruktionen om att dela såväl vinster som förluster och gärna från olika kartor, men i övrigt var beslutet om vilka matcher de ville dela upp till deltagarna. Forskningsdesignen erbjöd därmed deltagarna agens i datainsamlingen (Pink et al., 2016; Russell \& Barley, 2020).

Skärminspelningarna erbjöd dokumentation och insyn i spelvärlden (se 5.1 respektive 5.2). För att säkerställa att min förståelse av materialet var förankrad i deltagarnas upplevelser samt för att få insyn i deras vardag träffade jag dem även regelbundet i deras skola. Träffarna (totalt fyra mellan april 2017 och maj 2018) fungerade också som intervjuer och dokumenterades genom ljudinspelningar. Under intervjuerna användes videostimulerad återkoppling (Nguyen et al., 2013; Pitkänen, 2015; Lysberg, 2021) av relevanta sekvenser från skärminspelningar erbjöd insyn i deltagarnas tankar och reflektioner om specifika spelsituationer (se t.ex. Pink et al., 2016).

Tabell 1. Översikt över deltagande

\begin{tabular}{|c|c|c|c|c|c|c|c|}
\hline & \multicolumn{4}{|c|}{ Lag 1 (L1) } & \multicolumn{3}{|c|}{ Lag 2 (L2) } \\
\hline & Martin & John & Joni & William & Jesper & Emil & Sebastian \\
\hline $\begin{array}{l}\text { Intervju } 1 \\
\text { April } 2017\end{array}$ & + & - & + & + & + & + & + \\
\hline $\begin{array}{l}\text { Match } 1 \\
\text { Maj } 2017\end{array}$ & $\mathbf{x}$ & - & $x$ & 0 & 0 & $x$ & $x$ \\
\hline $\begin{array}{l}\text { Intervju } 2 \\
\text { September } 2017\end{array}$ & + & - & - & + & + & - & + \\
\hline $\begin{array}{l}\text { Match } 2 \\
\text { Oktober } 2017\end{array}$ & $\mathbf{x}$ & 0 & $x$ & 0 & 0 & $x$ & 0 \\
\hline $\begin{array}{l}\text { Match } 3 \\
\text { November } 2017\end{array}$ & $\mathbf{x}$ & - & $x$ & $x$ & 0 & $x$ & $x$ \\
\hline
\end{tabular}

(Fortsatt) 
Tabell 1. (Fortsatt)

\begin{tabular}{|c|c|c|c|c|c|c|c|}
\hline & \multicolumn{4}{|c|}{ Lag 1 (L1) } & \multicolumn{3}{|c|}{ Lag 2 (L2) } \\
\hline & Martin & John & Joni & William & Jesper & Emil & Sebastian \\
\hline $\begin{array}{l}\text { Match } 4 \\
\text { December } 2017\end{array}$ & $\mathrm{x}$ & o & $x$ & $x$ & o & $x$ & $x$ \\
\hline $\begin{array}{l}\text { Intervju } 3 \\
\text { Januari } 2018\end{array}$ & + & + & + & - & * & * & * \\
\hline $\begin{array}{l}\text { Match } 5 \\
\text { Februari } 2018\end{array}$ & $\mathbf{x}$ & $x$ & $x$ & o & $\mathbf{x}$ & $x$ & $x$ \\
\hline $\begin{array}{l}\text { Match } 6 \\
\text { April } 2018\end{array}$ & $\mathbf{x}$ & $x$ & $x$ & 0 & $\mathbf{x}$ & $x$ & $x$ \\
\hline $\begin{array}{l}\text { Match } 7 \\
\text { Maj } 2018\end{array}$ & $\mathbf{x}$ & $x$ & $x$ & - & $x$ & $x$ & $\mathrm{x}$ \\
\hline $\begin{array}{l}\text { Intervju } 4 \\
\text { Maj } 2018\end{array}$ & + & + & + & - & + & + & - \\
\hline
\end{tabular}

$X=$ deltog i matchen, skickade en skärminspelning till forskarna

$0=$ deltog i matchen, skickade inte in en skärminspelning/problem med deltagarens fil

$+=$ deltog i intervju

- = deltog inte

* = avbruten på grund av säsongsinfluensa

Analysen var primärt begränsad till två deltagares skärminspelningar: Martin från L1 och Jesper från lag 2 (L2). Eftersom intervjuerna var de enda tillfällen jag träffade deltagarna utgjorde de en viktig faktor i urvalet. Martin (pseudonym) deltog i samtliga intervjuer, delade skärminspelningar från alla matcher och är dessutom den erkänt mest erfarna spelaren i laget. Jesper (pseudonym) var den enda L2-medlemmen som deltog i samtliga intervjuer och matcher, men på grund av tekniska problem har forskaren enbart tillgång till tre av hans skärminspelningar. Deras respektive lagmedlemmar närvarar i skärminspelningarna och lagmedlemmarnas skärminspelningar utgjorde stöd om något var oklart. Alla deltagare har närvarat under minst två intervjuer och därmed är samtliga deltagares röster hörda. Utgående från detta urval består data av totalt tio matcher (totalt ca nio timmar) med matchlängd mellan 27 och 44 minuter. Båda lagen delade vinster och förluster och data består av fem vinster och fem förluster. Båda lagen har delat inspelningar från olika kartor. 
Data analyserades för att synliggöra spelarnas identitetskonstruktion. Skärminspelningarna och intervjuerna analyserades parallellt och analysen följde tre faser: (1) alla deltagares aktivitet observerades på skärminspelningarna och intervjuerna transkriberades när de ägde rum, (2) baserat på de inledande observationerna, identifierades relevanta situationer i skärminspelningarna och intervjuerna, (3) varpå jag och min medförfattare noterade fem kategorier av verktyg för identitetskonstruktion. I det här kapitlet fokuserar jag på ett sådant verktyg; diskurs präglad av stötande språkbruk (Ståhl \& Rusk, 2020).

\section{Etiska perspektiv}

Forskning bör inte förorsaka deltagarna skada, ska vara gynnsamt för dem då det är möjligt och deltagarna bör bemötas jämlikt och deras beslut respekteras (Murphy \& Dingwall, 2001). Ett antal åtgärder vidtogs för att deltagarna inte skulle uppleva forskningen som ett intrång i deras privatliv: standardåtgärder som att använda pseudonymer istället för deltagarnas riktiga namn och att informera studerande, föräldrar och lärare om studiens syfte och vad deltagande innebär. Genom skolaktivitet finns information om deltagarna tillgängliga online med namn, fotografi och spelarnamn. Därmed har spelarnamnen anonymiserats för att respektera deltagarnas anonymitet, se exempelvis figur 1 (Ståhl \& Rusk, 2022).

Genom att deltagarna själva genomförde skärminspelningarna fick de mer kontroll över datainsamlingen (Murphy \& Dingwall, 2001). Skärminspelningarna sändes över en krypterad fildelningsservice. Innan speldata visats utanför forskningsprojektet har den specifika sekvensen blivit tillbakasänd till deltagarna och enbart det material som deltagarna godkänt har publicerats, vilket även innefattar det här kapitlet. Som forskare hade jag tidigare erfarenhet av sådan praxis (se exempelvis Ståhl \& Kaihovirta; 2019; Rusk, 2019; Sahlström, et al., 2019). Kommentarer på forskningsdesignen i materialet, såsom exempelvis utdrag 1, möjliggjorde att jag kunde förtydliga studiens intention under intervjuerna (se avsnitt 5.3 för mer utförlig diskussion). 


\section{Spelarjargong som norm}

Videoforskning, här genom skärminspelningar, kan erbjuda insikt i privata sfärer forskare i övrigt inte haft tillträde till. I likhet med tidigare forskning (Pulos, 2013; Kiourti, 2019), ser jag att spelmiljön online domineras av en spelarjargong med ett hårt språkbruk. I utdrag 1 diskuterar L2 huruvida de får och bör svära då matchen dokumenteras i forskningssyfte och når slutsatsen att de får svära, men att de kommer göra det i begränsad utsträckning (se rad 5). Underliggande den här förhandlingen finns ett antagande om att de i vanliga fall svär och/eller använder ett hårt språkbruk då de spelar tillsammans.

\section{Utdrag 1. EVC. T2: match 1, Mirage.}

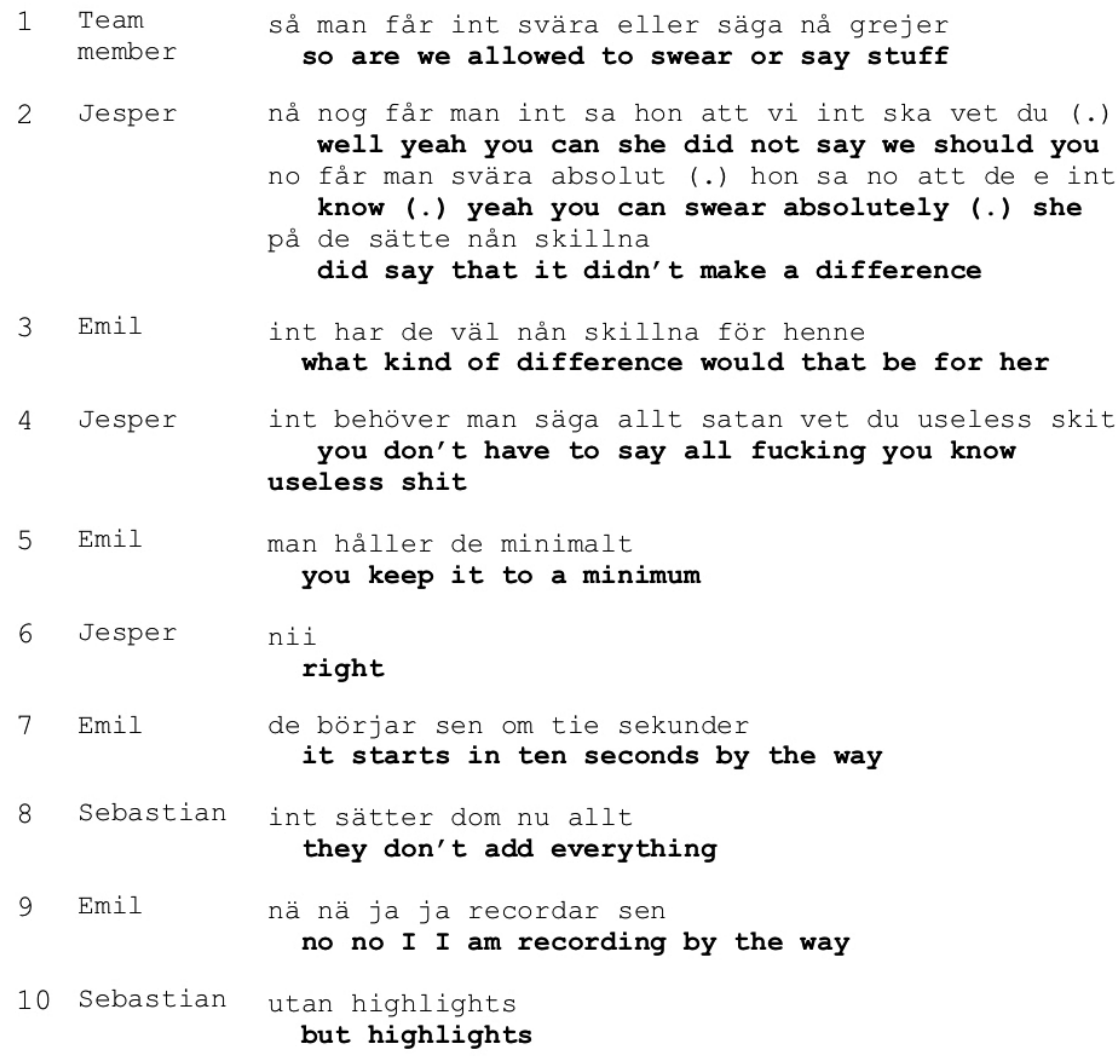

Tidigare analys av materialet visar att språkbruket i spelkulturen online tenderar att innehålla ord med kvinnliga konnotationer eller 
nedvärderande ord för homosexuella män (Ståhl \& Rusk, 2020) för att beskriva spelare vars handlingar avviker från den normativa synen på hur man bör spela. Exempelvis kan det handla om strategier och/eller val av vapen som anses vara fega eller genvägar till en säker vinst. I materialet sker diskursen på olika språk och förekommande ord är exempelvis "vittu" (finska för kvinnors genitalier), och "faggot" (engelskans motsvarighet till svenskans "bög”). Såväl deltagarna i studien som slumpmässigt tilldelade medspelare och motståndare använder sådant språkbruk. I likhet med tidigare forskning på spelkultur (se exempelvis Sundén, 2012) finns även bland spelarna i materialet ett grundläggande antagande om att spelare är män. Båda lagen hänvisar till samtliga spelare som "han/ honom" (se exempelvis utdrag 2), även om de sällan har någon insyn i vem de spelar med och mot utöver det egna laget och vilka personliga pronomen spelarna identifierar sig med. De hänvisningar till "hon/ henne" som finns i materialet är i huvudsak riktade gentemot mig som forskare (se exempelvis utdrag $1, \operatorname{rad} 2$ ).

\section{Normen ifrågasätts}

Trots att ett hårt språkbruk är så vanligt förekommande i spelkulturen online att det uppfattas som normen för spelarjargong framkommer även individuella preferenser och/eller ställningstaganden. I materialet finns spelare som sällan eller aldrig använder sådant språkbruk, vilket kan ses som motstånd gentemot den dominerande normen. Vidare finns det även situationer då deltagarna direkt ifrågasätter spelarjargongen, se utdrag 2 och 3 .

Under den sista matchen som L1 delat är Martin frustrerad över att en motståndare som använder en $\mathrm{P}_{90}$ eliminerat honom. Martin har vid upprepade tillfällen påpekat att vapen som skjuter fler än ett skott åt gången utan stark rekyl (såsom P9o) inte kräver spelarskicklighet utan är så kallade "noob vapen ${ }^{2}$ ". Därmed upplever Martin att motståndaren bryter antagandet om att onlinespel ska vara rättvisa (Harper, 2013) och

2 En noob/noob är en person med begränsat kunnande inom en specifik kontext, ofta ett spel, som inte tar in råd från mer erfarna deltagare eller uttrycker en vilja att utvecklas. 
i sin frustration kallar han motståndaren för noob i den allmänna textchatten och ber motståndaren skaffa sig ett liv (se utdrag 2). John noterar Martins agerande och säger "toxic" med en humoristisk ton (se rad 7), men även om markeringen är rätt försiktig så upphör Martin att skriva i chatten. Även Joni påpekar att det upplevda övertaget är lätt åtgärdat genom att även Martin köper vapnet i fråga.

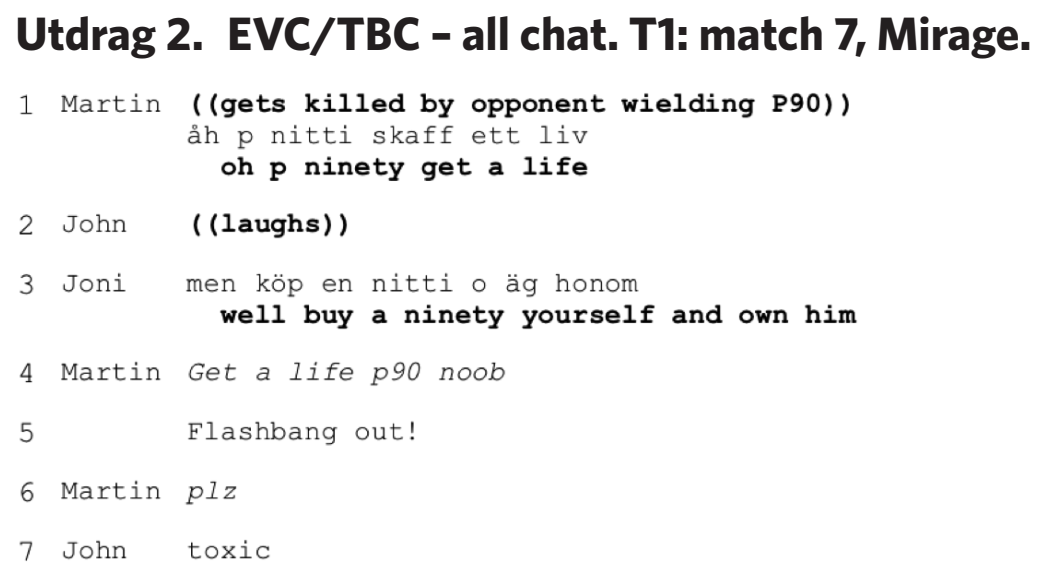

I en tidigare match med L1 läser John högt från textchatten, en vanligt förekommande praxis eftersom alla spelare i stundens hetta inte nödvändigtvis hinner uppfatta vad som skrivs. Han slutar läsa mitt i ett ord då han noterat vad motståndaren skrivit (se utdrag 3, rad 3). En kort tystnad uppstår och deltagarna reagerar på olika sätt: från att uttrycka förvåning i den laginterna röstchatten (se rad 4 och 6) till att direkt påpeka att sådant språkbruk inte accepteras och att spelaren bör rapporteras (se rad 5 och 7 ).

\section{Utdrag 3. EVC/TBC - all chat. T1: match 4, Cache.}

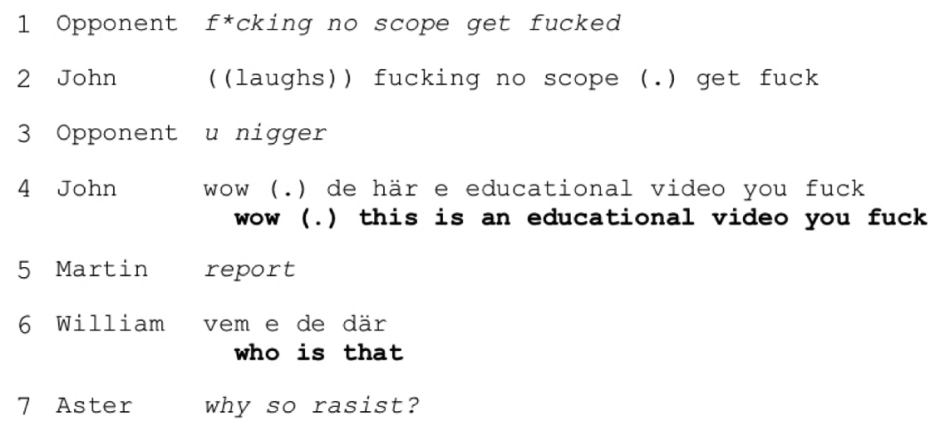


När ronden tar slut en dryg minut senare skriver motståndaren "sry I was hyped" i allchatten. Att vara hajpad (från engelskans hyped) innebär att vara väldigt upprymd eller engagerad. Deltagarna läser meddelandet högt upprepade gånger, skrattar och Martin säger "hajpad nog att skriva nigger” och fnyser. Deras reaktioner antyder att vara hajpad inte är en giltig orsak till att använda ett sådant språkbruk. Huruvida motståndaren genuint ångrar sig eller om hen önskar undvika att bli rapporterad (och eventuellt portförbjuden till spelet), så bemödar sig hen ändå att bemöta situationen efteråt. Därmed förhåller sig även motståndaren på något plan till språkbruket som opassande. Spelarjargong innebär därmed gråskalor; samma spelare kan stundtals gå med i jargongen för att sedan ifrågasätta andra spelares spelarjargong.

Här möjliggjordes analysen av spelarjargong genom att forskaren fick inblick i en privat sfär genom deltagarnas skärminspelningar under matchtid där även deras laginterna röstchatt ingår. Även om stötande språk kan betraktas som en del av spelupplevelsen fanns det också subtila kommentarer och ett tyst motstånd mot delar av jargongen. Stötande språkbruk användes ofta för att beskriva provocerande spelare och händelser i spelet, men även för att betona positiva egenskaper eller framgång. Lagdiskursen dikterade till vilken nivå stötande språk var lämpligt. Diskursen var en aktiv förhandling, exempelvis kommenterade enskilda spelare språket som de själva eller deras lagkamrater använde.

\section{Att beforska spelarjargong genom skärminspelningar}

Här lyfter jag fram tre perspektiv på skärminspelningar och de implikationer de har för pedagogisk videoforskning i virtuella och/eller digitalt medierade miljöer. Videoforskningen kontrasteras här gentemot fältanteckningar, en etablerad datainsamlingsmetod som även använts inom samtida forskning på spelvärlden online (se exempelvis Ruvalbaca et al., 2018). Det första perspektivet är att kunna se och återse data (5.1), det andra är tillgång till ett slutet rum (5.2) och det tredje är forskarblicken och analysfokus (5.3). 


\section{Att se och återse data}

Att göra fältanteckningar simultant som forskaren tar del av ett onlinespel med högt tempo är verkligt krävande. Då kan det vara fördelaktigt att göra anteckningar i efterhand, med risk för att glömma valda delar (Boellstorff et al., 2012). Till skillnad från observation och fältanteckningar, kan forskaren genom inspelningar (skärm eller video), återkomma till situationen som då den utspelade sig i realtid upprepade gånger (Russell \& Barley, 2020). Vidare är inspelningar även möjliga att dela med andra forskare, vilket innebär att samma händelse kan analyseras så som den skedde in situ ur olika perspektiv (Blikstad-Balas, 2017). I det här fallet innebar det att deltagarnas speldata kunde analyseras enligt olika forskningsingångar (exempelvis etnografiskt Ståhl \& Rusk, 2020 och samtalsanalytiskt Rusk \& Ståhl, 2020).

Forskarens förståelse av kontexten och därmed de instruktioner deltagarna fått begränsar urval av såväl deltagare som dokumenterade situationer. Genom helskärmsinspelningar kan forskaren se allt deltagaren ser och alla handlingar hen gör i spelvärlden. På så vis skiljer sig skärminspelningar från videoinspelningar då ett fotografi eller en film alltid är ett urval (Barthes, 1981). Till skillnad från observation och fältanteckningar är det däremot genom inspelningar möjligt att återgå till situationen så som den utspelade sig i realtid utan att vara direkt begränsad av forskarens initiala förståelse. Upprepat tittande kan dock resultera i en avtrubbning till materialet (Paakkari, 2020) men det finns även risk för förstoring (se engelskans magnification) där ingående analys av en specifik sekvens kan framställa ett fenomen som förstorat i relation till dess närvaro i materialet som helhet (Blikstad-Balas, 2017). Men upprepad återgång till materialet kan även erbjuda nya perspektiv eller analysingångar, exempelvis genom att notera sådana situationer som tidigare gått en förbi genom så kallat "omotiverat tittande" (Psathas, 1995). Exempelvis, hade jag och min kollega i den första analysomgången (Ståhl \& Rusk, 2020) enbart noterat händelseförloppet såsom det framgår i utdrag 3. Det var först i ett senare skede då en annan artikel på samma data var i tillblivelse (Rusk \& Ståhl, 2020) vi noterade att motståndaren återkommer till diskussionen efter rondens slut. Återgång till materialet upprepade gånger och möjligheten 
att se situationen utspela sig på nytt erbjöd här att vi bättre kunde förstå situationen i sin helhet.

Genom att använda sig av inspelningar är den pedagogiska forskaren inte direkt begränsad av den initiala förståelsen. Ökad förståelse för kontexten eller tillgång till nya forskningsrön kan erbjuda forskaren nya perspektiv i ett senare analysskede. Även om videomaterialet förutsätter tekniska lösningar för såväl insamling som korrekt lagring kan videoforskning ses som en effektiv metod då ett rikt forskningsmaterial kan analyseras utifrån ett flertal perspektiv med varierande fokus och/eller forskningsingångar.

\section{Tillgång till ett slutet rum}

Videodata av olika slag kan erbjuda forskaren insyn i sådana miljöer som hen i vanliga fall inte hade haft tillgång till. Boellstorff et al. (2012) noterar att det finns spelkontexter där det inte är möjligt att delta som enbart åskådare, utan forskaren själv är tvungen att delta för att få insyn i kontexten. Exempelvis kan spelarens direktsändningar (så kallade live streams) ge forskare insyn i spelvärlden, men i sådana direktsändningar ingår en performativ aspekt då spelaren medvetet delar sin spelupplevelse med en publik. Genom autoetnografiska skärminspelningar kan forskaren få insyn i spelmiljöer online (se exempelvis Sveningsson, 2012 och Sundén, 2012), men det förekommer även kontexter där forskaren på grund av sitt' "annorlundaskap" inte kan utgöra deltagare (T. L. Taylor, 2012). Problematiken är tämligen vanlig inom pedagogiken (med undantag för vuxenutbildning, se exempelvis Pastuhov \& Rusk, 2017) då det sällan möjligt för den pedagogiska forskaren att själv delta som studerande.

Även om jag som forskare på ett teoretiskt plan kunde söka in till e-sportprogrammet i fråga hade min ålder och könstillhörighet tydligt utmärkt mig i relation till de tonåriga män som dominerar programmets demografiska profil. En annan möjlighet hade varit att spela tillsammans med deltagarna och på så vis nå ett deltagarperspektiv. Ett sådant upplägg hade inte heller varit autentiskt eftersom mina meriter inom CS:GO är icke-existerande och min närvaro hade påverkat deltagarnas spelupplevelse. I samband med det hon kallar för spelintervjuer, dvs. att befinna 
sig i samma fysiska rum som deltagaren och intervjua deltagaren medan hen spelar valfritt spel, noterade Shaw (2014) att hennes närvaro påverkade spelupplevelsen. Eftersom noviser inom spelgemenskapen online ofta lär sig genom ett så kallat mästar-novis förhållande (Rusk, Ståhl \& Silseth, 2020, 2021) hade min närvaro som medspelare tilldelat deltagarna ett ansvar att stödja mig i spelandet och direkt inverkat på deras spelupplevelse och sannolikt även lagets prestationsnivå. Dessutom var lagen redan fulltaliga med fem av fem möjliga spelare och min närvaro hade därmed begränsat ordinarie lagmedlemmars möjlighet att spela tillsammans.

Det är dock värt att notera att jag trots mitt "annorlundaskap" har insyn i spelvärlden, professionellt men även privat som spelare, och därmed delade en grundläggande begreppsapparat med deltagarna. Det innebar att vi hade ett gemensamt språk kring spel och spelande vilket underlättade kommunikationen med deltagarna, men i likhet med Ráhka (2021) noterar jag att kulturell förståelse inte automatiskt är detsamma som ett deltagarperspektiv. Men genom att inkludera deltagarna i datainsamlingen kunde jag som forskare därmed nå förståelse av ett deltagarperspektiv av en kontext jag i övrigt inte har tillgång till. Ett exempel på en liknande lösning är projektet Textmöten där forskarna genom skärmspegling och -inspelning kunde dokumentera studerandes mobiltelefonanvändning under skoldagen (Rusk, 2019; Sahlström et al., 2019). Det kan även organiseras genom att låna ut videoutrustning åt deltagarna för att dokumentera språkanvändningen i hemmet (Rusk et al., 2012). Genom video- och skärminspelningar kan pedagogiska forskare nå sådana kontexter uppfattade som privata men med relevans för det pedagogiska forskningsfältet. Vidare kan den här typen av upplägg innebära att deltagandet i forskningsprojektet inte upplevs som inkräktande då deltagarna har agens i datainsamlingen.

\section{Forskarblicken och analysfokus}

Med en kamera närvarande på fältet blir forskarens närvaro synlig och hens fokus tydligt markerat då samtliga närvarande ser vem som kameran är (och inte är) fokuserad på. Vid första anblicken kan forskaren 
uppfattas som osynlig i skärminspelning då hen inte är fysiskt närvarande i det dokumenterade rummet, men jag hävdar i likhet med Pink et al (2016) att så inte är fallet. I utdrag 1 diskuterar L2 huruvida de får och avser svära då deras matcher spelas in i forskningssyfte och på rad 9 påminner Emil sina lagkamrater om att han för tillfället spelar in sin skärm och därmed deras konversation. Kommentarer, såsom påminnelser om att sätta igång inspelningen, förekommer rätt ofta i materialet och deltagarna tycks förhålla sig till inspelningarna som oproblematiska. Även om jag inte närvarar i materialet som en spelare påminns de om forskarblicken genom påminnelser från varandra men även från visuella markörer, såsom en röd blinkande prick, om att skärminspelning pågår.

I match 1 med L2 (samma match som utdrag 1) förekommer även en diskussion om huruvida de ska spela in ytterligare en match eller inte. Främst är det Jesper som framhåller att han gärna vill sända en annan match "var vi på riktigt spelar bra" då de för tillfället ligger under med fyra vunna rundor gentemot motståndarnas 14. Den här typen av diskussioner i materialet var väldigt viktiga i den fortsatta datainsamlingen, för att synliggöra vilka delar av forskningsdesignen som behövde förtydligas. Exempelvis kunde jag förtydliga att om de i vanliga fall svär då de spelar och är bekväma att göra det även under inspelningarna behövde de inte censurera sitt språkbruk för min del. Vidare kunde jag även påpeka att såväl vinster som förluster var värdefulla för min förståelse av kontexten och att deras individuella prestationer inte var mitt analytiska fokus. I likhet med tidigare videoforskningsprojekt (se exempelvis Rusk, 2019; Sahlström et al., 2019) blev deltagarna mer avslappnade vartefter nyhetens behag lagt sig och datainsamlingen fortskred. Efter att deltagarna fick ta del videomaterialet under den videostimulerade återkopplingen (Nguyen et al., 2013; Pitkänen, 2015; Lysberg, 2021), tycktes skärminspelningarna avdramatiserats och deltagarna blev mer bekväma med forskarens närvaro. Exempelvis noterar Martin i match 7, den sista matchen hans lag spelat in, att han genom att blåsa på den externa mikrofonen "spränger högtalarna på Matildas dator". Han fnissar åt tanken och upprepar sedan handlingen, vilket visar på att han uppfattar forskningen som tämligen odramatisk och till och med ett utrymme där han kan 
bete sig lekfullt. Vidare är det värt att notera att ingen deltagare valde att avbryta samarbetet.

\section{Diskussion}

Spelarjargong är ett värdeladdat ämne som intervjustudier kan erbjuda viktiga perspektiv på, men där svaren riskerar att snarare reflektera det deltagarna tror att forskaren vill höra och inte hur spelarjargong verkligen görs inom spelvärlden. Deltagarna har här generöst delat med sig av situationer som inte alltid framställer dem i ett smickrande sken. Ur ett spelforskningsperspektiv innebar skärminspelningarna att jag som forskare kunde utforska ett verkligt relevant fenomen såsom det skedde i stunden. Vidare möjliggjorde skärminspelningarna upprepad analys av samma sekvens där nya perspektiv framkom vartefter min förståelse för kontexten och forskningsfältet utvecklades.

Ur ett pedagogiskt perspektiv erbjuder skärminspelningar insyn i samtida kontexter med relevans för pedagogiken som forskaren i övrigt inte har tillträde till. Här möjliggjorde skärminspelningar insyn i spelarjargongen online, vilket i sin tur kan stödja pedagogerna i diskussioner om lämpligt språkbruk i ett spelsammanhang online. Genom studier såsom vår (Ståhl \& Rusk, 2020), synliggörs spelarjargongen men även hur spelare väljer att distansera sig från den. Insyn i spelarjargongens gråskalor och motsägelser kan erbjuda pedagogerna verktyg för att öppna upp den negativa inverkan ett hårt språkbruk kan ha. Studier såsom vår exemplifierar även de strategier som redan används för att ifrågasätta normen, vilket kan leda till pedagogiska diskussioner om huruvida de går att återskapa och om de kan vidareutvecklas för att göra spel mer inkluderande.

Skärminspelningar som verktyg för datainsamling är tämligen nytt och därmed skapar de flesta forskare egna tillvägagångssätt enligt rådande förutsättningar. Metodologiska diskussioner, såsom det här kapitlet och det bokkapitel jag samskrivit med Fredrik Rusk om etiska perspektiv på materialet (2022), bidrar till en enhetlig metod som samtidigt erbjuder utrymme för flexibilitet $\mathrm{i}$ enlighet med deltagarnas preferenser men även forskningsområde. I bokens förord uppmärksammas vikten av att förstå den praktik vi beforskar innan vi ämnar förändra den och att $\mathrm{i}$ enlighet 
med bokens tematik noteras att videoforskning kan möjliggöra den förståelsen. Det är min förhoppning att de tre perspektiv på skärminspelningar jag erbjuder här kan fungera som stöd för framtida pedagogiska videoforskningsprojekt på digital interaktion, såväl inom spel som andra plattformar. På det viset kan vi få bättre kunskap om hur miljöerna faktiskt är istället för att låta oss styras av normativa ingångar och perspektiv.

Genom att undersöka aktuella normer inom onlinespelkulturen ifrågasätter jag och mina kollegor dem indirekt och utmanar därmed teknomaskulinitetens grepp. Samtidigt lyfter vi frågan om hur skola och utbildning bidrar till normen. Eftersom normen dikterar att den ideala e-sportspelaren är manlig, vit, heterosexuell och tävlingsinriktad, måste konstruktionen av spelaridentitet återspegla dessa värden för att inte uppfattas som avvikande. Att konstruera identiteter som avviker från idealet möts för närvarande med motstånd, vilket resulterar i fortsatt begränsad tillgång till onlinespelkultur för normbrytande spelare. Denna studie understryker behovet av ytterligare icke-normativ forskning om onlinespelkultur, särskilt i relation till utbildning och e-sport.

\section{Referenser}

Barr, M. (2019). Graduate skills and game-based learning: Using video games for employability in higher education. Palgrave Macmillan.

Barthes, R. (1981). Camera lucida. Reflections on photography. Hill and Wang, New York.

Beaulieu, A. (2004). Mediating ethnography: Objectivity and the making of ethnographies of the internet. Social Epistemology, 18(2-3), 139-163. https://doi.org/10.1080/0269172042000249264

Blikstad-Balas, M. (2017). Key challenges of using video when investigating social practices in education: Contextualization, magnification, and representation. International Journal of Research and Method in Education, 40(5), 511-523. https://doi.org/10.1080/1743727X.2016.1181162

Boellstorff, T., Nardi, B., Pearce, C. \& Taylor, T. L. (2012). Ethnography and virtual worlds: A handbook of method. Princeton University Press.

Gee, J. P. (2007). What video games have to teach us about learning and literacy. Palgrave Macmillan.

Gray, K. L. (2020). Intersectional tech. Black users in digital gaming. Louisiana State University Press. 
Hammersley, M. (2018). What is ethnography? Can it survive? Should it? Ethnography and Education, 13(1), 1-17. https://doi.org/10.1080/17457823.2017.1298458

Harper, T. (2013). The culture of digital fighting games: Performance and practice. Routledge.

Harvey, A. (2015). Gender, age, and digital games in the domestic context. Routledge.

Johnson, R. (2018). Technomasculinity and its influence in video game production.

I N. Taylor \& G. Voorhees (Red.). (2018), Masculinities at play (s. 249-262).

Springer Nature Switzerland.

Kinnunen, J., Lilja, P. \& Mäyrä, K. (2018). Pelaajabarometri 2018. Monimuotoistuva mobiilipelaaminen. TRIM research reports, 28.

Kinnunen, J., Taskinen, K. \& Mäyrä, M. (2020). Pelaajabarometri 2020. Pelaamista koronan aikaan. TRIM research reports, 29.

Kiuorti, E. (2019). "Shut the fuck up re! 1 plant the bomb fast!” Reconstructing language and identity in first-person shooter games. I A. Ensslin \& I. Balteiro (Red.), Approaches to videogame discourse: Lexis, interaction, textuality (s. 157-177). Bloomsbury Academic.

Lysberg, J. (2021). Video-stimulated recall som datainnsamlingsmetode. I F. Rusk (Red.), Videoforskning på ulike loeringsarenaer: Mangfoldig videodata i pedagogisk forskning og utvikling (Kap. 4, s. 81-99). Cappelen Damm Akademisk. https://doi. org/10.23865/noasp.153.ch4

Maloney, M., Roberts, S. \& Graham, T. (2019). Gender, masculinity and video gaming: Analysing Reddit's r/gaming community. Springer Nature.

Murphy, E. \& Dingwall, R. (2001). The ethics of ethnography. I P. Atkinson,

A. Coffey, S. Delamont, J. Lofland \& L. Lofland. (Red.), Handbook of ethnography (s. 339-351).

Nakamura, L. (2009). Don't hate the player, hate the game: The racialization of labor in World of Warcraft. Critical Studies in Media Communication, 26(2), 128-144. https://doi.org/10.1080/15295030902860252

Nguyen, N. T., McFadden, A., Tangen, D. \& Beutel, D. (2013). Video-stimulated recall interviews in qualitative research. Proceedings of the Australian Association for Research in Education Annual Conference (s. 1-10). Adelaide, South Australia.

Paakkari, A. (2020). Entangled devices. An ethnographic study of students, mobile phones and capitalism [Doctoral dissertation, University of Helsinki, Helsinki].

Parker-Jenkins, M. (2018). Problematising ethnography and case study: Reflections on using ethnographic techniques and researcher positioning. Ethnography and Education, 13(1), 18-33. https://doi.org/10.1080/17457823.2016.1253028

Pastuhov, A. \& Rusk, F. (2018). Citizenship as individual responsibility through personal investment - an ethnographic study in a study circle. European Journal for Research on the Education and Learning of Adults, 9(1), 95-108.

Pink, S., Horst, H., Postill, J., Hjorth, L. \& Tacchi, J. (2016). Digital ethnography. Principles and practice. Sage. 
Pitkänen, J. (2015). Studying thoughts: Stimulated recall as a game research method. I Game research methods (s. 117-132).

Pulos, A. (2013). Confronting heteronormativity in online games: A critical discourse analysis of LGBTQ sexuality in World of Warcraft. Games and Culture, 8(2), 77-97. https://doi.org/10.1177/1555412013478688

Ráhka, S. N. (2021). Etiske aspekter ved videoforskning i et lite miljø. I F. Rusk (Red.), Videoforskning på ulike loeringsarenaer: Mangfoldig videodata i pedagogisk forskning og utvikling (Kap. 2, s. 37-54). Cappelen Damm Akademisk. https://doi. org/10.23865/noasp.153.ch2

Rambusch, J., Jakobsson, P. \& Pargman, D. (2007). Exploring e-sports: A case study of gameplay in Counter-strike. Situated Play. Proceedings of the 3 rd Digital Games Research Association International Conference (s. 157-164). Tokyo, Japan.

Ratan, R. A., Taylor, N., Hogan, J., Kennedy, T. \& Williams, D. (2015). Stand by your man: An examination of gender disparity in League of Legends. Games and Culture, 10(5), 438-462. https://doi.org/10.1177/1555412014567228

Rusk, F., Ståhl, M. \& Silseth, K. (2021). Player agency, team responsibility and selfinitiated change: An apprentice's learning trajectories and peer mentoring in eSports. I M. M. Harvey \& R. Marlatt (Red.), Esports research and its integration in education. IGI Global. https://doi.org/10.4018/978-1-7998-7069-2

Rusk, F., Ståhl, M. \& Silseth, K. (2020). Exploring peer mentoring and learning among experts and novices in online in-game interactions. I P. Fotaris (Red.), Proceedings of the 14th International Conference on Game Based Learning (s. 461-468). Academic Conferences International Limited.

Rusk, F. \& Ståhl, M. (2020). A CA perspective on kills and deaths in Counter-Strike: Global offensive video game play. Social Interaction. Video Based Studies of Human Sociality, 3(2). https://doi.org/10.7146/si.v3i2.117066.

Rusk, F., Pörn, M., Sahlström, F. \& Slotte-Lüttge, A. (2012). Everything, everywhere, all the time: Advantages and challenges in the use of extensive video recordings of children. I Responsible Research. Papers from the Fourth Qualitative Research Conference (s. 67-78).

Rusk, F. (2019). Digitally mediated interaction as a resource for co-constructing multilingual identities in classrooms. Learning, Culture and Social Interaction, 21, 179-193.

Russell, L. \& Barley, R. (2020). Ethnography, ethics and ownership of data. Ethnography, 21(1), 5-25.

Ruvalcaba, O., Shulze, J., Kim, A., Berzenski, S. R. \& Otten, M. P. (2018). Women’s experiences in esports: Gendered differences in peer and spectator feedback during competitive video game play. Journal of Sport and Social Issues, 42(4), 295-311.

Sahlström, F., Tanner, M. \& Olin-Scheller, C. (2019). Smartphones in classrooms: Reading, writing and talking in rapidly changing educational spaces. Learning, Culture and Social Interaction, 22. https://doi.org/10.1016/j.lcsi.2019.100319 
Shaw, A. (2015). Gaming at the edge: Sexuality and gender at the margins of gamer culture. University of Minnesota Press.

Schwandt, T. A. \& Gates, E. F. (2018). Case study methodology. I N. K. Denzin, N. K. \& Y. S. Lincoln (Red.), The Sage handbook of qualitative research (5. utg., s. 341-358). Sage.

Shumar, W. \& Madison, N. (2013). Ethnography in a virtual world. Ethnography and Education, 8(2), 255-272. https://doi.org/10.1080/17457823.2013.792513

Sundén, J. (2012). A queer eye on transgressive play. I J. Sundén \& M, Sveningsson (Red.), Gender and sexuality in online game cultures (s. 171-19o). Routledge.

Sveningsson, M. (2012). 'Pity there's so few girls!' Attitudes to female participation in a Swedish gaming context. I J. Fromme \& A. Unger (Red.), Computer games and new media cultures: A handbook of digital games studies (s. 425-441). Springer.

Ståhl, M. \& Kaihovirta, H. (2019). Exploring visual communication and competencies through interaction with images in social media. Learning, Culture and Social Interaction, 21, 250-266.

Ståhl, M. \& Rusk, F. (forthcoming) Maintaining participant integrity - ethics and fieldwork in online video games. I L. Russell, J. Tummons, \& R. Barley (Red.), Ethics, ethnography and education. Emerald Publishing.

Ståhl, M. \& Rusk, F. (2020). Player customization, competence and team discourse: Exploring player identity (co)construction in Counter-Strike: Global Offensive. Game Studies, 20(4). http://gamestudies.org/2004/articles/stahl_rusk

Taylor, N. (2016). Play to the camera: Video ethnography, spectatorship, and e-sports. Convergence: The International Journal of Research into New Media Technologies, 22(2), 115-130.

Taylor, N. \& Voorhees, G. (2018). Introduction: Masculinity and gaming: Mediated masculinities at play. I N. Taylor \& G, Voorhees (Red.), Masculinities at play (s. 1-19). Springer Nature Switzerland.

Taylor, T. L. (2012). Raising the stakes: E-sports and the professionalization of computer gaming. MIT Press.

Taylor, T. L. (2009). Play between worlds. Exploring online game culture. MIT Press.

Witkowski, E. (2018). Doing/undoing gender with the girl gamer in highperformance play. I K. L. Gray, G. Voorhees. \& E. Vossen (Red.), Feminism in play (s. 185-203). Springer Nature Switzerland.

Valve Corporation \& Hidden Path Entertainment. (2012). Counter-Strike: Global Offensive [Microsoft Windows]. Digital game published by Valve Corporation.

Voorhees, G. \& Orlando, A. (2018). Performing neoliberal masculinity: Reconfiguring hegemonic masculinity in professional gaming. I N. Taylor \& G. Voorhees (Red.), Masculinities at play (s. 211-227). Springer Nature Switzerland.

Vossen, E. (2018). The magic circle and consent in gaming practices. I K. L. Gray, G. Voorhees \& E. Vossen (Red.), Feminism in play (s. 205-220). Springer Nature Switzerland. 


\title{
Det store i det lille: Detaljert videoanalyse av gruppearbeid
}

\author{
Ingvill Berg \\ FIRST Scandinavia
}

\section{Fredrik Rusk}

Nord Universitet, Bodø \& Åbo Akademi, Vasa, Finland

\begin{abstract}
The purpose of this chapter is to discuss the use of video data to analyze at the micro level how groups share resources and knowledge with each other and how this may relate to how we understand and conceptualize learning in a video study. Video gives us the opportunity to study interaction at a detailed level and observe situations repeatedly. It also creates a unique opportunity to understand what happens in the interaction between students in group work when the teacher is not present. This study focuses on the actual social practices and more specifically on how students express what they know to each other and how they negotiate knowledge when they work together with practical tasks in groups. It examines how students situationally negotiate knowledge in group work and tries to make visible and understand what is being done, moment by moment, in the social interaction and how it may be linked to learning as a social phenomenon.
\end{abstract}

Keywords: group work, epistemics in interaction, learning, video analysis, conversation analysis

Videodata, sammen med samtaleanalyse, er velegnet til å finne ut hva elever og lærere gjør og sier, og hva det betyr for dem der og da (Melander \& Sahlström, 2010; Walsh, 2011; Waring, 2016). Grunnpilaren i samtaleanalyse er hvordan menneskelig sosial interaksjon er strukturert og organisert, og dens beskrivelse skal begrunnes i data; oftest video (Schegloff, 2007). Hensikten med dette kapitlet er å diskutere hvordan man kan studere og oppfatte læring som sosial aktivitet gjennom å bruke videodata 
for å analysere hvordan elever som gjør gruppearbeid forhandler om kunnskap med hverandre i gruppearbeid. Videodata gir oss mulighet til å studere situasjoner gjentatte ganger (Rotvik Tverbakk, 2021) for å fange opp nyanser og detaljer i den sosiale interaksjonen som vi ikke ser eller oppdager ved første blikk (Arntzen et al., 2021), og som vil gi oss økt forståelse om det deltakerne gjør (Bahdanovich, Hanssen \& Krogtoft, 2021; Rønning, 2021).

Dette kapitlet forstår læring som en aktivitet og hevder ikke å kunne påpeke hva (innhold) deltakerne lærer eller ikke lærer (Rusk, 2016). Målet er å studere læring som en sosial aktivitet som interaksjonsdeltakere utfører og gjør (Lee, 2010). Å danne seg en bedre forståelse av sosial interaksjon kan sees i sammenheng med et perspektivskifte hvor forståelse av læring blir sett på som iboende sosialt (Lave \& Wenger, 1991; Sfard, 1998; Säljö, 2000, 2017). Dermed bidrar perspektivskiftet til å forsterke betydningen av hva individer gjør i klasserommet og til å peke på et økende behov for kunnskap om sosiale prosesser i klasserommet. Læring er, ut fra et sosialt syn, en del av deltakernes aktiviteter i sosial interaksjon. Samtaleanalyse er en metode for å kunne synliggjøre, på et detaljert nivå, hvordan vi gjør aktiviteter og handlinger sammen. Sosial aktivitet er alltid et nettverk av metoder for meningsskaping som er avhengige av hverandre. For eksempel, å «gjøre læring» innebærer instruksjon og en gjensidig orientering mot å endre en deltakers kunnskap om et læringsobjekt. Men å gjøre læring krever, i seg, et nettverk av sosiale handlinger og aktiviteter (kunnskapsforhandling, reparasjon og andre metoder for meningsskaping) for å opprettholde en delt forståelse for hva det er de gjør, inklusive en forståelse for at de gjør læring (Heritage, 2018; Rusk, 2016). Med andre ord kan en empirisk og deskriptiv analyse av læring som en identifiserbar sosial aktivitet bidra til å forstå andre deler av de komplekse prosessene som vi kaller læring.

\section{Gruppearbeid og sosial interaksjon}

I dette kapitlet er gruppearbeid oppgaver læreren gir der det er tenkt at elevene skal jobbe sammen, i par eller grupper, for å løse en eller flere oppgaver. I gruppearbeid flyttes det interaksjonelle ansvaret fra lærer til elev, og en konsekvens av dette er at ansvaret for læring også blir 
flyttet mer over på elevene (Sahlström, 2017). Gruppearbeid er forskjellig fra plenumsundervisning når det gjelder elevenes muligheter til deltakelse (Jakonen \& Morton, 2015; Melander, 2012; Rusk \& Rønning, 2020; Seedhouse, 2004), men det kan også ha en segregerende effekt hvis det ikke gjøres på en ordentlig måte (Emanuelsson \& Sahlström, 20o8; Klette et al., 2018). Det er sannsynlig at det i gruppearbeid er i samtalene mellom elevene vi kan finne antydninger til læring, men som lærer er man sjelden med i disse situasjonene. Det er her video er et viktig verktøy. I stedet for å basere vårt syn på gruppearbeid på synsing og flyktige observasjoner, kan videoopptak gi oss mulighet til å studere interaksjonen gjentatte ganger og på detaljnivå (Rotvik Tverbakk, 2021).

For å bedre forstå gruppearbeid, samarbeid og læring som sosial aktivitet, må man analysere interaksjonen på mikronivå (Melander \& Sahlström, 2010). Som interaksjonsdeltakere oppfatter vi enkelt og kjapt mange ting som vi «bare gjør» og som er i grenselandet mellom bevisste og ubevisste handlinger. Disse handlingene har dog mye å si for hvordan vi for eksempel forhandler om hvem som kan og vet hva. For å kunne vise til disse handlingene i kunnskapsforhandlinger, trenger vi spesialisert terminologi som samtaleanalysen tilbyr (Goodwin, 200o; Schegloff, 2007). Til denne terminologien tilhører det som kan kalles, på norsk, for et «analytisk rammeverk for kunnskapsforhandlinger i interaksjon» (Heritage, 2018, vår oversettelse).

\section{Kunnskapsforhandlinger}

Mennesker har en interesse i å forstå hvem som kan og vet hva, og utfører og forstår handlinger i interaksjon basert på (til dels) denne forståelsen av hvem som kan og vet hva (Heritage, 2018; Schegloff, 2007). Ved hjelp av et analytisk rammeverk for kunnskapsforhandlinger i interaksjon, kan man bedre forstå samarbeid og relasjoner i sosial interaksjon (Heritage, 2018). Det er to begreper som er viktige i dette rammeverket: epistemisk status og epistemisk posisjonering. Epistemisk status er forventningen til at noen av samtaledeltakerne har mer eller mindre kunnskap om et gitt tema i forhold til andre i samtalen (Solem, 2016). Samtaledeltakere har tilgang til hvert sitt kunnskapsområde, og ethvert spesifikt element av kunnskap kan komme 
inn i disse områdene, men som regel i ulik grad. Denne relative tilgangen til et kunnskapsområde fordeles mellom deltakerne slik at de inntar forskjellige posisjoner på en gradient, som mer kunnskapsrik (K+) eller mindre kunnskapsrik (K-) (Heritage, 2018). Epistemisk posisjonering er hvordan en deltaker posisjonerer seg som mer (K+) eller mindre (K-) kunnskapsrik i forhold til andre, og det kan komme til uttrykk verbalt og/eller kroppslig (Heritage, 2018). Man viser til egen og andres epistemiske status gjennom å epistemisk posisjonere seg (med ord og/eller kroppslig) i interaksjon; det vil si, man orienterer seg mot sin egen og andres kunnskap gjennom hvordan man uttrykker sin egen og andres kunnskap i samtalen.

Kunnskapsforhandlinger blir ofte aktuelle mellom elever i gruppearbeidsoppgaver, der de får plass til å uttrykke sin kunnskap og tenkning (Melander \& Sahlström, 2010; Rusk et al., 2017). Måten deltakerne uttrykker sin kunnskap på og måten de orienterer til andre deltakeres uttrykte kunnskap har vist seg å være av betydning for samarbeidet (Rusk \& Rønning, 2020). Elevene åpner opp for eller avslutter ytterligere kunnskapsforhandlinger gjennom hvordan de uttrykker sin kunnskap og orienterer seg mot andres uttrykte kunnskap (Melander, 2012; Rusk et al., 2017).

I denne teksten diskuterer vi hvordan man kan studere og oppfatte læring som sosial aktivitet gjennom å analysere hvordan elever som gjør gruppearbeid forhandler om kunnskap med hverandre. Det analytiske rammeverket er nødvendig for å analysere og formidle det store i det lille; kunnskapsforhandlingene som deltakerne gjør sammen (Heritage, 2018; Rusk, 2016).

\section{Data}

Observasjonene er hentet fra videoopptak av undervisning i et Newtonrom. Et Newton-rom er en læringsarena som deles av skoler i en kommune som har topp moderne STEM-utstyr for utforskende og undersøkende undervisning og læring. Skoleeierne er ansvarlige for aktivitetene i rommene, som utføres av lærere som har fått spesifikk opplæring om «læringsmodulene» som tilbys i rommene. Læringsmodulene er utviklet enten av såkalte Newton-lærere eller av stiftelsen First Scandinavia, og har gjennomgått en kvalitetssikringsprosess før de ble publisert på Newtons 
nettsted (www.newton.no). Vanligvis besøker klasser Newton-rommet en eller to ganger hvert skoleår. Klassene gjør forberedende arbeid på skolen før besøket og oppfølgingsarbeid etter besøket. Under besøket i Newton-rommet deltar elevene på forelesninger og jobber i grupper på to til fire for å løse forskjellige STEM-relaterte oppgaver.

Fokus i dette kapitlet er ikke på datainnsamlingen i seg selv; hensikten er heller å diskutere analysen og mulighetene med en slik analytisk tilnærming. Datainnsamlingen må likevel presenteres, ettersom det er en stor og viktig del av helheten (se f.eks. Rusk et al., 2014). Data, som helhet, omfatter 8 forskjellige grupper fra to forskjellige klasser (til sammen ca. 40 timer videodata) som alle ble filmet hele dagen som de var på Newton-rommet. De aktuelle opptakene som brukes for å eksemplifisere kunnskapsforhandlingene i denne studien er fra to klasser på 6. trinn. Vi fokuserer på to grupper, en gruppe fra hver klasse, men analysen er basert på den større mengden analysert materiale. Gruppene arbeider med samme praktiske matematikk-oppgave. Den ene gruppen består av Nora og Elise, den andre av Anne og Lars. Oppgaven går ut på å kjøre så nært en Lego-figur som mulig med en robot, uten å berøre figuren. Elevene har fått oppgitt avstanden mellom start og Lego-figuren til å være $165 \mathrm{~cm}$. De har ikke fått oppgitt omkretsen på hjulene, men har utstyr til å finne ut dette. På bordet har de en robot, nettbrett, ekstra hjul og en boks med målebånd, tommestokk, tråd, teip og kalkulator. Videre har de et oppgaveark og blyant. Roboten er en vesentlig del av aktiviteten. Transkripsjonen er basert på transkripsjonssystemet utviklet av Jefferson (2004), se vedlegg 1.

Studien følger etiske standarder og personvernregler i samsvar med prinsippene om respekt for deltakere og etisk behandling av mennesker som deltar i forskning, og er gjennomgått og godkjent av Norsk samfunnsvitenskapelig datatjeneste og Datatilsynet. Videoopptak er etisk følsom data og krever derfor også spesiell forsiktighet og respekt. I tillegg til lærerne og elevene, har foreldrene til de elevene som ønsket å delta bekreftet dette ønsket skriftlig. Bare elever med foreldre som ga dette samtykket var en del av opptakene. Deltakernes velvære og konfidensialitet ble kontinuerlig vurdert under datainnsamlingen. I tillegg til reglene som gjelder god etisk praksis, har vi spesifikt informert deltakerne om deres rett til å trekke seg tilbake når som helst, samt om hvordan innspilt innhold kan 
kontrolleres og slettes i ettertid. Disse retningslinjene ble brukt strengt og ensartet på alle videoutdrag. Gjennom hele studien har vi hele tiden vurdert (og revurdert) de etiske imperativene til disse opptakene.

\section{Analyse}

Analysen er basert på totalt fire utdrag som viser hvordan deltakerne organiserer seg i gruppearbeidet på ulike måter og også hvordan de i ulik grad forhandler om kunnskap. Gjennom utdragene vil vi diskutere bruken av videodata for å analysere på detaljnivå hvordan elevene forhandler om sin og andres kunnskap i en gruppearbeidssammenheng og hvordan den analysen kan bidra til forståelsen for hvordan læring gjøres som sosial aktivitet.

\section{Aktive kunnskapsforhandlinger - samarbeid og læring i interaksjon}

Før situasjonen har Nora og Elise snakket om hva de skal gjøre og hvordan, men kommer ikke frem til noe de kan bli enige om. Situasjonen starter med at Nora gir uttrykk for at hun har ny kunnskap om steget videre ( $\operatorname{rad} 1)$ ved å bruke ordet 'å'. Lengden på banen er $165 \mathrm{~cm}$, og Nora er inne på at roboten skal kjøre litt kortere enn det for ikke å treffe Legomannen ( $\mathrm{rad} 2)$. Hun kommer med tre ulike forslag på lengder. Hun ender på en lengde som er to centimeter unna linja der Lego-mannen vil stå og begrunner valget overfor Elise $(\operatorname{rad} 2)$. Videre uttrykker Nora at hun er usikker på om lengden de har notert seg er den korrekte ( $\operatorname{rad} 3)$, og orienterer seg slik som K- når det gjelder det kunnskapsområdet. Hun forholder seg også til Elise som K- innen dette området da hun sier at de må spørre (lærer) om banen ( $\operatorname{rad} 3)$.

Elise, derimot, posisjonerer seg som $\mathrm{K}+$ og sier at lengden er fra Legomannen og til «den» (der hvor roboten skal starte, rad 5). Selv om Elise uttrykker sikkerhet for at de har oppfattet lengden rett og gir svar på det som Nora synes de må spørre om, påstår Nora at Elise ikke hører på henne, og adresserer oppgaven over til henne ( $\operatorname{rad} 6)$. Da hevder Elise epistemisk status som K- gjennom å si at hun ikke vet ( $\operatorname{rad} 8)$. Noras «ja» 
i starten på samtaleturen i rad 9 tyder på at hun heller ikke forventet at Elise skulle vite hvordan oppgaven skulle løses, men ønsket en bekreftelse på det. Hun posisjonerer seg som K+ og orienterer til Elise som K- når hun sier at hun har en plan, men at Elise ikke hører på. Elise protesterer på dette og mener at hun hører på (rad 10).

\section{Utdrag 1}

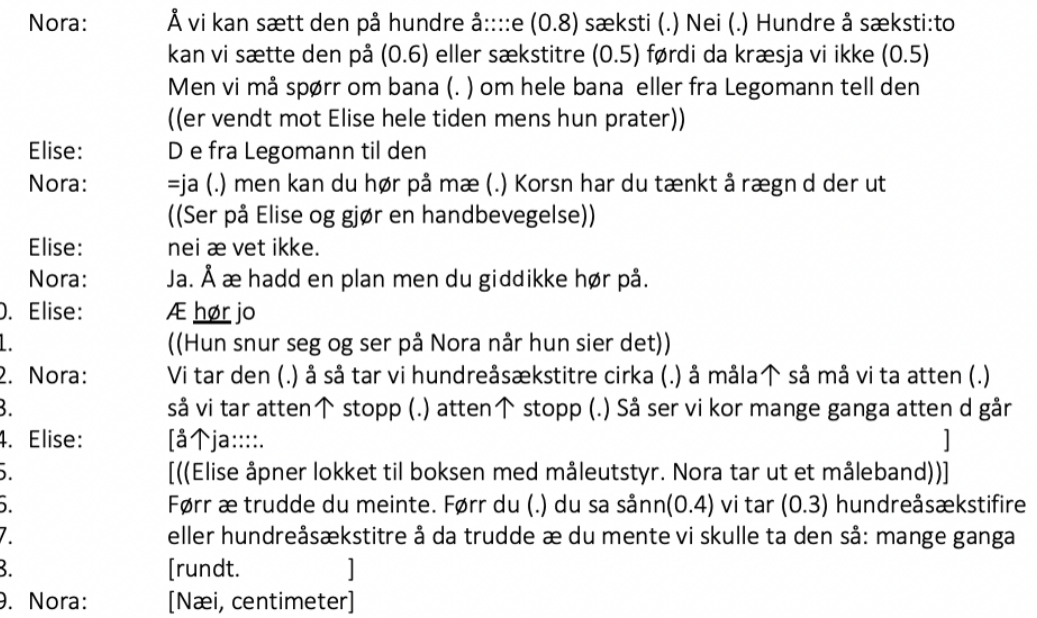

Nora aksepterer dette og tar det som en invitasjon for å forklare sin idé. Hun hevder igjen $\mathrm{K}+$ status ved å innlede en faglig forklaring ( $\operatorname{rad} 12-13)$. Elises svar viser at hun nå forstår noe hun tidligere ikke forstod ( $\operatorname{rad} 14)$. Dette er også en anerkjennelse av Noras plan ved å signalisere at hun nå forstår. Videre forklarer Elise at hun trodde Nora mente at tallet var antall rotasjoner ( $\mathrm{rad} 16-18)$, men Nora bekrefter at det var feil antakelse, da hun mente centimeter ( $\operatorname{rad} 19)$. Dette viser at de nå har rettet opp i en misforståelse som var en hindring for det videre arbeidet.

De forhandler om hvem som kan og vet hva og begrunner sine egne påstander. I og med at tallet var veldig nært lengden på banen, forsterker det oppfattelsen av at Nora snakket om centimeter. På den andre siden kan måten Nora uttrykker seg på i rad 1 ha bidratt til Elises misforståelse, da det å «sætte den på ...» ofte referer til å legge inn antall rotasjoner i programvaren til roboten. Hva som gjør at Nora kan påstå at Elise ikke hører på henne kommer ikke tydelig frem i denne sekvensen. Det kan være at 
misforståelsen skaper en situasjon der de snakker forbi hverandre, fordi den gjør at de ikke har en felles forståelse til grunn.

Nora og Elise vet at omkretsen til hjulet er 18 centimeter og skal i utdrag 2 finne ut hvor mange ganger atten går i 163 centimeter, distansen de ble enige om i utdrag 1 . Nora tar blyanten ( $\operatorname{rad} 1)$ og bruker den på målebåndet mens hun teller centimeterne høyt. Hun kommer til atten, og finner ut at hun skal starte på nytt. Elise bøyer seg over henne og tar blyanten ut av Noras hånd ( $\operatorname{rad} 9)$. Ved å si «Vi kan bare» ( $\operatorname{rad} 8)$ og «D vi kan gjør» ( $\operatorname{rad} 10)$ samtidig som hun tar blyanten, gir hun en grunn for at hun gjør det. Hun hevder en posisjon som K+ og skriver noe ned på arket. Det skaper en forventning om at det hun har skrevet på arket skal bidra til å komme videre i løsningen av oppgaven. Nora fortsetter sin utregning ( $\operatorname{rad} 11)$, men ser så på det Elise har skrevet. Nora ser ned på arket, så på Elise og ned på arket igjen og sier «hæ» mens hun rister litt på hodet ( $\operatorname{rad} 13-15)$. Hun posisjonerer seg som K- i forhold til Elises forslag. Elise forklarer at de kan lage tellestreker hver gang de kommer til atten ( $\operatorname{rad} 16)$. Nora viser at hun forstår hva Elise mente ( $\operatorname{rad} 17-18)$. Hun er på linje med Elises orientering som $\mathrm{K}+$, men fortsetter så med sin utregning ved å ta blyanten tilbake fra Elise (rad 19). Ved å begynne å skrive på arket og si hva hun gjør (rad 18-19) gir hun en grunn for at hun tar blyanten og hevder epistemisk status som $\mathrm{K}+$. Verken Elise eller Nora protesterer når den andre tar blyanten fra dem.

\section{Utdrag 2}

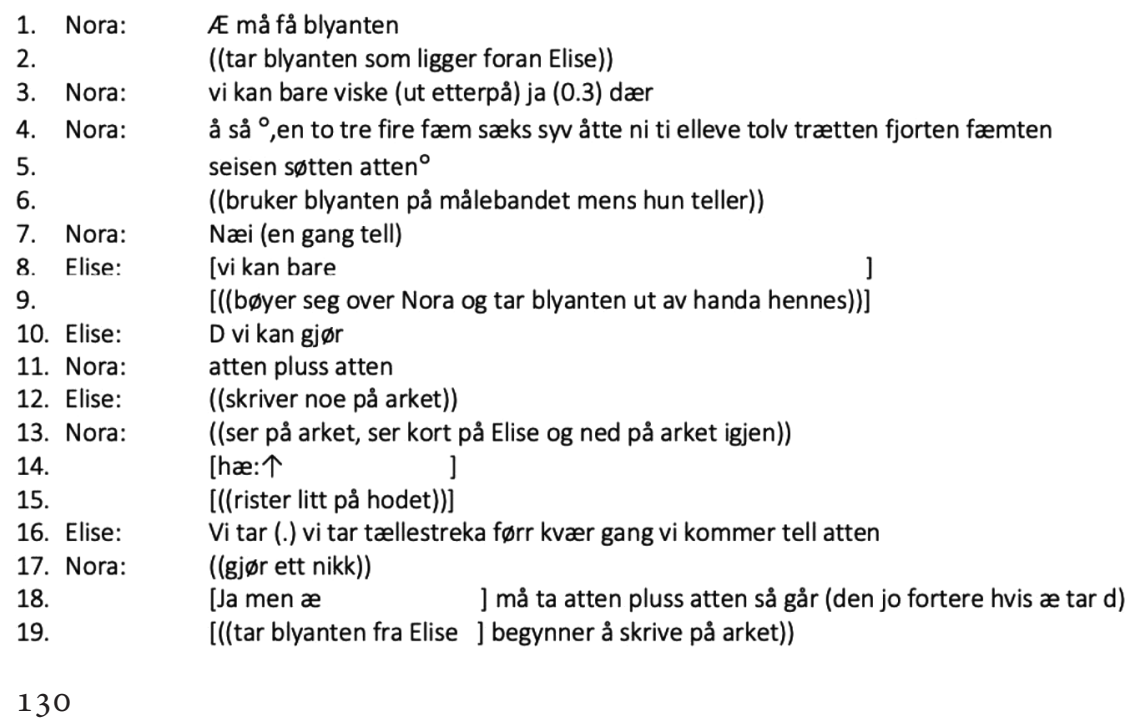


Utdrag 1 viser hvor viktig det er å stille spørsmål når man ikke forstår, og også begrunne hva man mener. På den måten kan man rydde opp i en misforståelse. Denne reparasjonen av misforståelsen viser seg å være avgjørende for Noras og Elises videre arbeid, ettersom de ender opp med å bruke den strategien. Utdrag 2 viser at materielle ressurser spiller en rolle i kunnskapsforhandlinger. Det at de lar hverandre bruke blyanten kan virke som noe lite, men i denne situasjonen påvirker blyanten hvem som styrer samtalen og legger frem forslag. Blyanten brukes for å posisjonere seg i samtalen, og posisjonene er dynamiske. Utdragene med Nora og Elise viser hvordan de gjennom kunnskapsforhandlinger og gjennom deling av materielle ressurser samarbeider for å løse problemer, fullføre oppgaven og gjøre læring. Det er ingen av deltakerne som har et klart svar på hvordan de skal løse oppgaven, men de jobber seg stegvis fremover og begge bidrar med forslag til løsninger som den andre orienterer seg mot. De stilles også til ansvar for det de påstår at de vet. Begge er aktive bidragsytere til å gjøre læring og til sin egen forståelse av oppgaven og deres strategi for å løse den.

\section{Individuell innsats i gruppearbeid - en utfordring for videoanalyser av læring som aktivitet}

I utdrag 3 skal Anne og Lars sette i gang med oppgaven. Anne tar en bit teip og begynner å legge teipen rundt hjulet. Hun forklarer ikke hva hun gjør eller skal gjøre, og spør ikke Lars om assistanse. Mens Anne legger på teip lager Lars en lekeøks av tommestokken som han holder i hånden. Situasjonen starter med at Anne sier «tjuesæks kåmma fæm» mens hun skriver det ned på et ark ( $\operatorname{rad} 1-2)$. Lars posisjonerer seg som K- når han spør om det er runder ( $\operatorname{rad} 3$ ). Anne bekrefter at hun har hørt Lars sitt spørsmål ved å se på ham (rad 5), og korrigerer ham for så å forklare at det er lengden på hjulet. De kikker begge mot noe en annen gruppe gjør utenfor kameravinkelen.

Anne snakker høyt mens hun arbeider videre med oppgaven (rad 12-14). Hun skriver på arket, henter kalkulatoren og regner sammen omkretsen på hjulet med lengden etthundre og seksti og noe centimeter. Det er vanskelig å høre det som blir sagt, men svaret ender på ni. Lars sier 
hun må huske på mikrofonen som ligger på bordet (rad 15). Anne kommenterer ikke Lars sitt innspill, og fortsetter med sin utregning som hun sier høyt ( $\operatorname{rad} 17)$. Lars kommenterer at noe smalt ( $\operatorname{rad} 18)$. Han går ikke inn i kunnskapsforhandlinger med Anne, og kommenterer ikke det hun gjør eller sier. På den måten forholder han seg til seg selv som K- og til Anne som $\mathrm{K}+$, som den som kan mer og kan ta dem videre i arbeidet med oppgaven. Anne henvender seg til Lars med en idé hun har fått, og ser på Lars og smiler ( $r a d ~ 24-26)$. Ideen hun deler med Lars innebærer svingning, og går utenfor det de har fått i oppgave. De blir avbrutt av lærer som gir en felles beskjed til alle ( $\operatorname{rad} 27)$. Anne ser på lærer og uttrykker at hun ikke forstår hva lærer sier og orienterer til seg selv som K- (rad 30). Lars snur seg mot Anne og sier «hæ» ( $\operatorname{rad} 31$ og 32) og posisjonerer seg som K-. Det at Lars ser på Anne når han er spørrende, indikerer på at han leter etter svar hos henne.

\section{Utdrag 3}

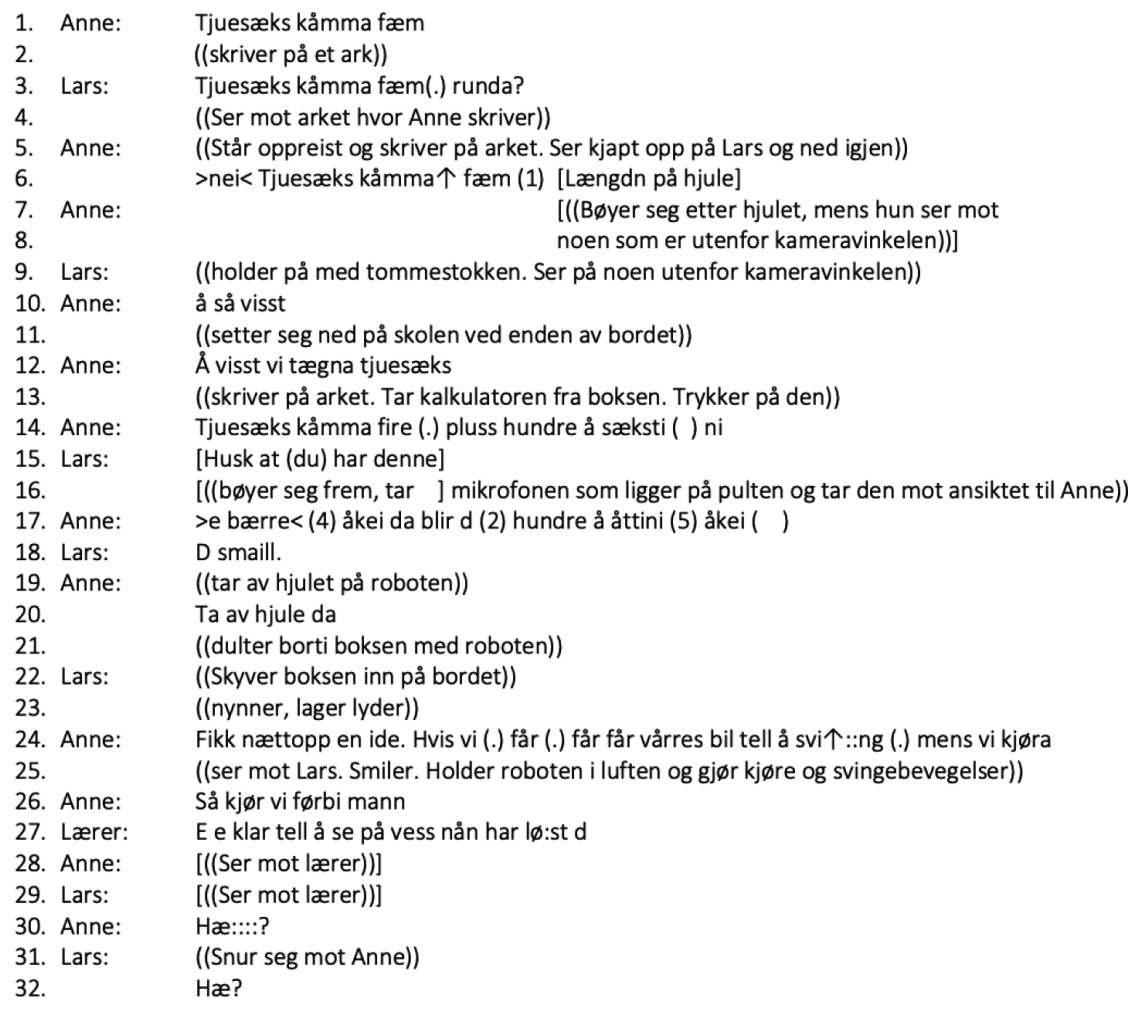


Utdrag 3 eksemplifiserer hvordan arbeidet forløper mellom Anne og Lars. Anne forklarer og snakker høyt om hva det er hun gjør, men det er mer som tale rettet til seg selv og ikke så mye til Lars. Lars orienterer også imot talen som at det er Anne som taler til seg selv. Utdrag 3 viser også at Lars orienterer mot Anne som K+. Dette har også å gjøre med hvordan Anne arbeider. Hun bruker de materielle ressursene tydelig og klart i sine handlinger og virker å ha en plan. Lars orienterer seg mot det og lar henne jobbe. Men han melder seg ikke helt ut, han spør når han lurer på noe og følger med på hva hun gjør, selv om han gjør det litt ved siden av. Den detaljerte analysen av situasjonen gir oss verktøy for å kunne oppdage dette. Hvis man bare ser på situasjonen uten å gå nøye inn på hvordan Anne og Lars forholder seg til hverandre, kan man enkelt overse det at Lars ikke melder seg fullstendig ut.

I utdrag 4, som skjer bare noen minutter etter utdrag 3, sitter Anne ved enden av bordet. Hun trykker på roboten med venstre hånd og holder borti nettbrettet med sin høyre. Lars sitter ved siden av bordet, holder et målebånd i hendene og ser mot noen utenfor kameravinkelen og spør om de skal prøve å kjøre roboten sin på robotbanen (rad 1-2). Lars ber om tillatelse av Anne til å gå og se på ( $\operatorname{rad} 4)$. Anne viser at det nesten var et unødvendig spørsmål gjennom bruken av «så klart» (rad 5). Lars går, og etter et par sekunder følger Anne etter. Hun roper «vent» og noe om hvorfor hun også må se (rad 8). De er borte i 18 sekunder og kommer så tilbake. Det at de kommer tilbake etter forholdvis kort tid (det tar tid når du skal se på noen gjøre testkjøring på et robotbord) tyder på at de kanskje har sett noe ved bordet som kan hjelpe dem til å gjøre oppgaven sin ferdig.

Anne starter roboten med en gang hun er tilbake ( $\operatorname{rad} 12)$. Hun trykker på nettbrettet, sier flere ganger «åkei» og snakker høyt med lys stemme om det hun gjør ( $\operatorname{rad} 15)$. Hun posisjonerer seg som $\mathrm{K}+$ og signaliserer trygghet med at hun kjører programmet på roboten og fører fingeren rundt i lufta foran hjulet, i takt med hjulets omdreining. Det tyder på at hun teller antall rotasjoner. Nå posisjonerer Lars seg som $\mathrm{K}+$ med en kommentar der han sier hvor mange rotasjoner det ble ( $\operatorname{rad} 17)$. Dette skjer samtidig med at Anne sier noe ( $\operatorname{rad} 18)$. Lars gjentar sin ytring (rad 20) og igjen blir det i overlapp med Anne, som virker å tenke på noe annet og er på vei bort fra bordet med roboten ( $\operatorname{rad} 21)$. Hun reiser seg og tar roboten med seg når hun går litt vekk fra bordet. 
Lars krever ikke at Anne skal vise at hun har hørt han si hvor mange rotasjoner det var. Men han lener seg frem på stolen og ser mot Anne (rad 23) når han posisjonerer seg som $\mathrm{K}+$ og korrigerer Anne ved å si at hun ikke får lov til å sjekke (rad 25, lærer har sagt at ingen får testkjøre antall rotasjoner før de kommer til robotbordet). Anne avkrefter at hun gjør noe som ikke er lov ( $\operatorname{rad} 26)$, og Lars svarer på en måte som viser at han nå skjønner hva hun gjør og hvorfor det ikke er å jukse (rad 27). Anne går bortover mens hun holder den kjørende roboten i hånda ( $\operatorname{rad} 28)$. Lars følger med på det Anne gjør, og bidrar til kunnskapsforhandlingen da han kommenterer at det var litt for langt ( $\operatorname{rad} 30)$. Anne orienterer seg fortsatt som K+ når hun bekrefter Lars sitt bidrag som riktig i rad 32 . Bruken av «ja» sist i samtaleturen forsterker graden av enighet med Lars og viser også at hun er den som har «siste ordet», sånn som når de telte rotasjoner og Lars ga svaret, men Anne ikke var fornøyd med måten de gjorde det på og ville gjøre det mens hun går med roboten i luften.

\section{Utdrag 4}

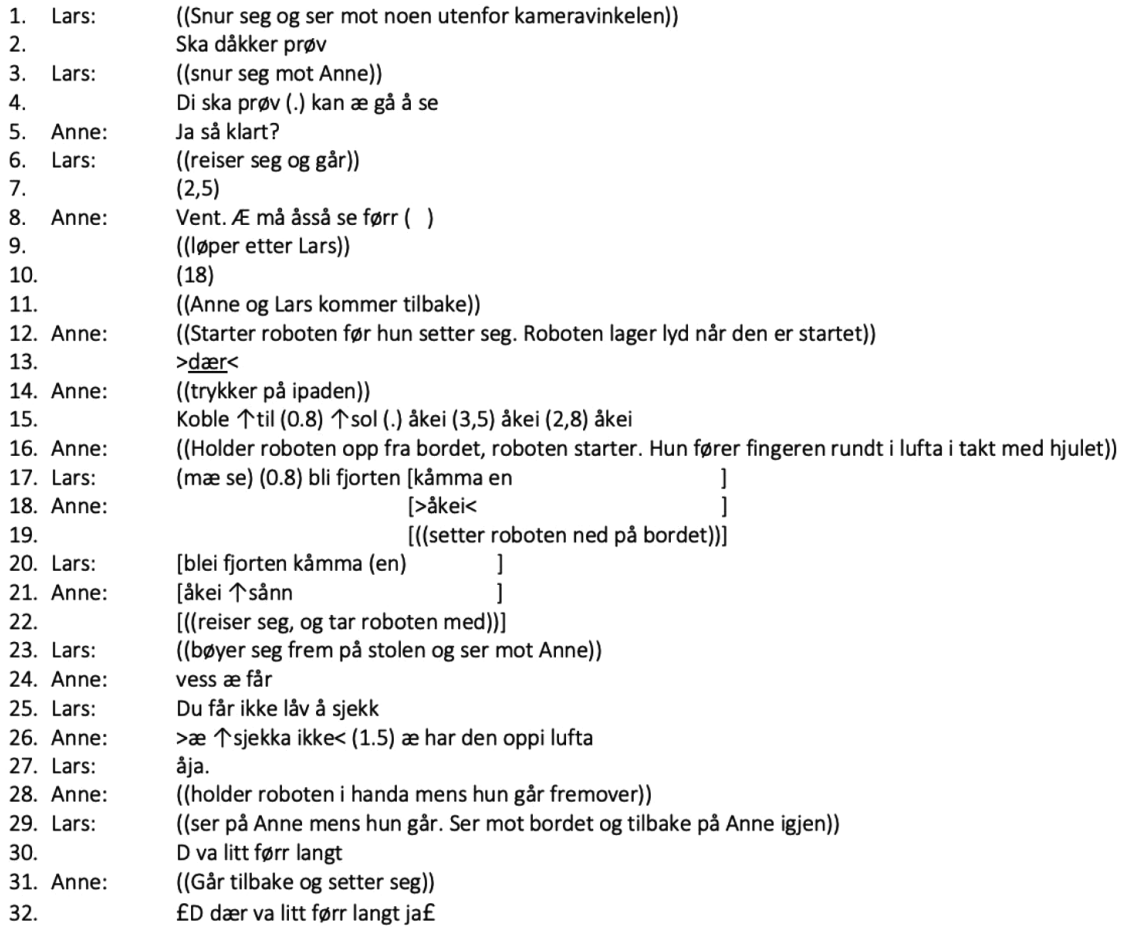


I utdrag 4 kan man se hvordan Lars orienterer mot Anne som den som leder oppgaven, for eksempel når han spør om lov til å gå og se på når noen skal prøve på banen. Anne gir ham lov, og her kan man se en tendens til at hun ser det som helt innenfor at Lars ikke bidrar så mye til oppgaven de gjør. Hun har ikke en forventning om at han skal bidra så mye. Likevel ser man i utdrag 4 at Lars også bidrar til kunnskapsforhandlingen og oppgaven i de deler som han henger med på; det at man ikke får lov å teste, at den lengden som hun hadde programmert roboten å kjøre var for lang og hvor mange rotasjoner roboten kjørte når hun holdt den foran seg. Uansett, så er det Anne som orienteres mot som K+. Det er hun som styrer strategien de bruker og hvordan de tenker seg å løse oppgaven. Lars kommer ikke med forslag til å endre på noe eller til hvordan det eventuelt kan endres, og han stiller ikke spørsmål for å få svar på hva det er for strategi de bruker. Han bidrar først og fremst ved å konstatere faktum som, for eksempel, at det var for langt eller hvor mange rotasjoner det var.

Utdrag 3 viser hvordan Anne er den som har kontroll over hvordan de skal løse oppgaven. Hun snakker høyt om hva hun gjør, og deler på den måten hvordan hun tenker. Men Lars utfordrer det ikke, og kommer ikke med forslag til hvordan de kan gjøre det annerledes. Utdrag 4 viser hvordan Lars bidrar til kunnskapsforhandlingen. Han konstaterer at man ikke får lov å sjekke og at det er for langt, men så bidrar han ikke mer enn det. Han kommer ikke med forslag til endringer og stiller ikke spørsmål til hvordan Anne jobber. Med andre ord orienterer begge mot hennes strategi som den de bruker, og hun får ha kontroll over det. På den måten er, og blir, kunnskapsforhandlingen lukket. Ikke fordi de posisjonerer seg som sterkt vitende eller uvitende og ikke gir seg på de posisjonene, men mer fordi de ikke utfordres i egen strategi og tenking. De trenger ikke engang å hevde sterke posisjoner, fordi den andre bare går med på å gjøre det sånn som de gjør det. En årsak til at Lars ikke bidrar mer, er at de ikke virker å ha en felles forståelse om deres felles strategi. Måten Lars bidrar til kunnskapsforhandlingene viser dette, når han ikke utfordrer og stiller spørsmål om hvordan eller hvorfor, men mer bidrar med å konstatere direkte observerbare ting og regler. 


\section{Oppsummering av analyse}

Utdrag 3 og 4 er eksempler på sosial interaksjon i gruppearbeid hvor kunnskapsforhandlinger stort sett er fraværende. I forhold til det vi vet om viktigheten av aktiv deltakelse i et sosialt fellesskap (Säljö, 200o, 2017) er disse funnene mer bekymringsfulle med tanke på læring enn når interaksjonen er preget av motstand og aktiv kunnskapsforhandling (se f.eks. utdrag 1 og 2). Det er en asymmetri i gruppen som er relativt statisk gjennom hele arbeidet. Anne er den som posisjonerer seg som mer kunnskapsrik, og hun blir ikke utfordret i noen større grad av Lars. Hun åpner heller ikke opp for kunnskapsforhandlinger med ham på samme måte som Nora og Elise gjør i utdrag 1 og 2. Anne sier hele tiden hva hun gjør, og inkluderer Lars på den måten. Men hun trenger aldri begrunne hvorfor hun gjør det, Lars gjør ikke krav på kunnskapsbidraget. Anne og Lars deler heller ikke materielle ressurser. Anne har kontroll på artefaktene i begge sekvensene, og Lars gjør ikke krav på disse. Utdrag 3 og 4 er interessante eksempler på hvordan en kunnskapsforhandling kan være lukket selv om ingen av deltakerne lukker den gjennom å hevde sterke kunnskapsposisjoner. Den forblir lukket fordi ingen av deltakerne utfordrer den valgte strategien og tenkingen. Utdragene er også interessante ettersom de utfordrer et syn på læring som aktivt og sosialt, samt hvordan man skal analysere læring som aktivitet i slik gruppeinteraksjon. Hvordan skal man håndtere slike situasjoner i analyser om samarbeid og læring?

Selv om det ikke er tydelige kunnskapsforhandlinger i Lars og Annes interaksjon, vil vi likevel si det er en åpning for det i samhandlingen. Anne snakker høyt mens hun arbeider med oppgaven, og gir med det Lars en mulighet til å komme med innspill i samtalen. Hun inntar heller ikke en sterk kunnskapsposisjon. Lars kommer med innspill i noen tilfeller. Likevel blir det ikke kunnskapsforhandlinger. Anne må ikke begrunne det hun vet, og Lars krever heller ingen forklaringer. I utdrag 4 kommer Lars med ytringer knyttet til det Anne gjør ( $r a d ~ 17$ og 20). Anne responderer ikke på disse (usikkert om hun hører det han sier), men Lars gjør ingen krav på å bli hørt. Det er ikke åpenbart av det vi ser i videoene at Anne er på rett vei når det gjelder å ha en løsning på oppgaven. Dersom Lars hadde krevd forklaringer på hvorfor Anne gjør og sier det 
hun gjør, kunne det bidratt i prosessen med å løse oppgaven. Det ville vært en bevisstgjøring også for Anne og hennes læring, og Lars ville fått en mulighet til å bidra faglig. I stedet virker det som han er komfortabel med å være litt perifert til stede.

\section{Diskusjon}

Læring skjer gjennom deltakelse (Lave \& Wenger, 1991), den er situert og skjer i samhandling med andre (Säljö, 2017). Det krever da at deltakerne ikke bare lytter til hverandre, men også deltar i kunnskapsforhandlinger. Gjennom å uttrykke det de vet og ikke vet i samhandling med hverandre, vil de kunne få muligheter for læring (Rusk, 2016). Nora og Elise deltar aktivt i kunnskapsforhandlinger med hverandre. De krever å få komme med innspill, og de begrunner sine påstander og ytringer. Dette gir et godt utgangspunkt for læring. I tillegg er fokuset for samhandlingen relevant for oppgaven, og hjelper deltakerne til å komme fremover mot en løsning.

Diskusjonen om læring og analysen av læring som aktivitet blir problematisert mer når det gjelder situasjoner som utdrag 3 og 4. På en måte gir den detaljerte analysen verktøy som hjelper en å se at det skjer aktivitet, men den aktiviteten er ikke på nivå med det som i litteraturen kalles aktivitet som leder til læring. Det at deltakerne jobber med individuelle prosjekter blir mer problematisk sett i forhold til læringsarbeid i grupper. Elevene har i disse tilfellene få eller ingen kunnskapsforhandlinger med hverandre, noe som er ugunstig for læringsarbeidet hvis man forstår kunnskap som noe som blir konstruert gjennom aktiv deltakelse i sosiale fellesskap (Melander \& Sahlström, 2010; Säljö, 2017). Dette er ikke bare en analytisk utfordring for videoforskning, men også en didaktisk utfordring i bruken av gruppearbeid som organisasjonsform i læringsarbeid i realfag. Kanskje det som den detaljerte analysen kan bidra med, er å gjøre oss mer bevisste på hvilke faktorer som påvirker læringsarbeidet i grupper. Begge gruppene ser ut til å være fokusert på oppgaven, og ingen snakker (mye) om annet. Dette, og hele analysen, kan vi basere på faktisk videodata, og ikke på spekulasjoner om hvorvidt dette er sant eller ikke. Det er ulik grad av kunnskapsforhandlinger, men elevene er fokusert på å 
løse oppgavene, enten felles eller individuelt. Det er et godt utgangspunkt for å jobbe videre med læringsprosesser.

\section{Konklusjon}

I dag er synet på læring som naturlig del av menneskelig hverdagssosialitet en selvfølge. Likevel er det fortsatt usikkerhet rundt hvordan vi gjør læring som sosial aktivitet. Læringen som studeres og diskuteres i dette kapitlet er av mikrosekvensiell karakter. Det betyr at det ikke stilles longitudinelle krav til læring eller utvikling over lengre tid. Denne formen for empirisk analyse kan vise hvordan deltakere gjør læring på mikronivå, det vil si det store i det lille. Læring er ikke noe som «bare skjer», eller som kun kan oppfattes som langsiktig; deltakerne kan, i hver liten situasjon, aktivt velge å gjøre læring og orientere seg mot å gjøre læring i samråd med hverandre. I kapitlet kan vi vise hvordan deltakernes håndtering av deres og andres relative kunnskap om læringsobjektet leder til endring i deres felles forståelse av oppgaven og mulige løsninger på oppgaven. Vi viser også begrensninger i denne formen av analyse og forståelse av læring, gjennom å analysere en gruppe som ikke oppviser mye aktivitet som viser til noen form for kunnskapsforhandling.

Relevant kritikk av en studie som denne er at materialet kan virke for lite, og at det ikke nødvendigvis betyr at noen av deltakerne har lært noe. Det vi ønsker å vise er at det er en merverdi i å gå inn på dette nivået av mikroanalyse i studier av læring. Målet vårt med kapitlet har vært å analysere situasjonene basert på et sosialt syn på læring. Med dette utgangspunktet er det ikke individet som er i fokus, men den sosiale situasjonen og hva deltakerne i den gjør og orienterer seg mot gjennom samhandling. Læring som sosial aktivitet er mangesidig, og i dette kapitlet kan vi ikke gå inn på alle deler av det (se f.eks. Lee, 2010; Melander, 2012; Rusk, 2016; Sahlström, 2011). Men styrken i et samtaleanalytisk og sosialt perspektiv på læring er at det kan vise det mangefasetterte i hvordan deltakere i sosial interaksjon uttrykker til hverandre hva de kan og vet om det de jobber med der og da. 


\section{Referanser}

Emanuelsson, J. \& Sahlström, F. (2008). The price of participation: Teacher control versus student participation in classroom interaction. Scandinavian Journal of Educational Research, 52(2), 205-223.

Goodwin, C. (2000). Action and embodiment within situated human interaction. Journal of Pragmatics, 32(10), 1489-1522. https://doi.org/10.1016/So378-2166(99) ooog6-X

Heritage, J. (2018). The ubiquity of epistemics: A rebuttal to the 'epistemics of epistemics' group. Discourse Studies, 2o(1), 14-56. https://doi.org/10.1177/1461445 617734342

Jakonen, T. \& Morton, T. (2015). Epistemic search sequences in peer interaction in a content-based language classroom. Applied Linguistics, 36(1), 73-94.

Jefferson, G. (2004). Glossary of transcript symbols with an introduction. I G. Lerner (Red.), Conversation analysis: Studies from the first generation (s. 13-31). John Benjamins.

Klette, K., Sahlström, F., Blikstad-Balas, M., Luoto, J., Tanner, M., Tengberg, M. et al. (2018). Justice through participation: Student engagement in Nordic classrooms. Education Inquiry, 9(1) 57-77. 10.1080/20004508.2018.1428036

Lave, J. \& Wenger, E. (1991). Situated learning. Cambridge University Press.

Lee, Y.-A. (2010). Learning in the contingency of talk-in-interaction. Text and Talk, $30(4), 403-422$.

Melander, H. (2012). Transformations of knowledge within a peer group: Knowing and learning in interaction. Learning, Culture and Social Interaction, 1(3-4), 232-248. https://doi.org/10.1016/j.lcsi.2012.09.003

Melander, H. \& Sahlström, F. (2010). Lärande i interaktion. Liber.

Rusk, F. (2016). Doing second language learning: A CA study of learning practices in Finnish-Swedish bilingual educational settings [Upublisert doktorgradsavhandling]. Åbo Akademi.

Rusk, F., Pörn, M., Sahlström, F. \& Slotte-Lüttge, A. (2014). Perspectives on using video recordings in conversation analytical studies on learning in interaction. International Journal of Research and Method in Education, 38(1), 39-55. https://doi.org/10.1080/1743727X.2014.903918

Rusk, F., Sahlström, F. \& Pörn, M. (2017). Initiating and carrying out L2 instruction by asking known-answer questions: Incongruent interrogative practices in bi- and multilingual peer interaction. Linguistics and Education, 38, 55-67. https://doi.org/10.1016/j.linged.2017.02.004

Rusk, F. \& Rønning, W. (2020). Group work as an arena for learning in STEM education: Negotiations of epistemic relationships. Education Inquiry, 11(1), 36-53. https://doi.org/10.1080/20004508.2019.1638194 
Sahlström, F. (2017). Vad händer egentligen under lektionerna? I S.-E. Hansén \& L. Forsman (Red.), Allmändidaktik: Vetenskap för lärare (2. utg., s. 175-198). Studentlitteratur.

Schegloff, E. A. (2007). Sequence organization in interaction: A primer in conversation analysis I. Cambridge University Press.

Seedhouse, P. (2004). The interactional architecture of the language classroom. Blackwell.

Sfard, A. (1998). On two metaphors for learning and the dangers of choosing just one. Educational Researcher, 27(2), 4-13. https://doi. org/10.3102/0013189X027002004

Solem, M. S. (2016). Hvem vet best? En samtaleanalytisk studie av elever og loereres kunnskapsforhandling i helklassesamtaler [Doktorgradsavhandling, Universitetet $\mathrm{i}$ Oslo]. DUO vitenarkiv. http://hdl.handle.net/10852/61005

Säljö, R. (200o). Lärande i praktiken. Prisma.

Säljö, R. (2017). Lärande och lärandemiljöer I S.-E. Hansén \& L. Forsman (Red.), Allmändidaktik: Vetenskap för lärare (2. utg., s. 147-174). Studentlitteratur.

Walsh, S. (2011). Exploring classroom discourse: Language in action. Routledge.

Waring, H. Z. (2016). Theorizing pedagogical interaction. Routledge. 


\section{Vedlegg 1}

\section{Transkripsjonsnøkkel}

[ord] Overlappende tale

$=\quad$ Sømløs overgang mellom to rader (dvs. uten pause)

(1.5) Pause målt i tidels sekunder

(.) Mikropause (under o,2 sekunder)

o:rd Lydforlengelse

? Stigende intonasjon

, Fortsettende intonasjon

. Fallende intonasjon

ord Trykksterkt ord eller stavelse

ORD Høyere volum enn omkringliggende tale

${ }^{\circ}$ ord $^{\circ} \quad$ Lavere volum

$\uparrow \downarrow \quad$ Forhøyet eller nedadgående toneleie, som følger etter tegnet

$>$ ord $<$ Hurtigere tale

$<$ ord $>$ Langsommere tale

£ord£ Lattermildstemme

ord- Avbrudd i talestrømmen (cut-off)

(ord) Usikker transkripsjon

() Uidentifiserbar tale

.hh Hørbar innpust

hh Hørbar utpust

(( )) Beskrivelser av ikke-språklige handlinger, og andre kommentarer 



\section{Del 3}

\section{Video som ressurs for utvikling av profesjonell kunnskap og praksis}





\title{
Video som endringsverktøy i pedagogisk utviklingsarbeid
}

\author{
Wenche Rønning
}

Nord universitet

\begin{abstract}
In this chapter the focus is on the use of video to support teachers' professional learning. After presenting theory and central concepts regarding how teachers learn, a case is used to explore the use of video in a lesson study inspired approach. The context is a process where teachers and researchers cooperate to revise an existing content module in mathematics used in a so-called Newton room, a learning arena with state-of-the-art learning resources shared by many schools in a geographical area. Teachers and researchers watch video excerpts from group work in the Newton room, which results in quite in-depth reflection about several central elements such as use of language and concepts, group dynamics, cooperation skills, design of tasks and learning resources, supervision, etc. The process results in considerable revision of the module as well as ample opportunities for teachers' authentic professional learning.
\end{abstract}

Keywords: authentic professional learning, action research, lesson study, learning from experience, reflection

\section{Introduksjon}

Skolen - og verden rundt den - er i rask endring, noe som medfører at lærere blir stilt overfor utfordringer som handler om å stadig utvikle sin egen praksis. Det er ikke nok å ha en grunnutdanning; det å være lærer blir en del av en livslang læringsprosess som varer yrkeslivet ut. Utfordringene inkluderer økt press og forventninger om at praksisen skal bli mer effektiv, at den skal være evidensbasert, og at den skal gi gode resultater for de elevene som omfattes av den (Webster-Wright, 2009). Det å forbedre læreres

Sitering: Rønning, W. (2021). Video som endringsverktøy i pedagogisk utviklingsarbeid. I F. Rusk (Red.), Videoforskning på ulike loeringsarenaer: Mangfoldig videodata i pedagogisk forskning og utvikling (Kap. 7, s. 145-164). Cappelen Damm Akademisk. https://doi.org/10.23865/noasp.153.ch7

Lisens: CC BY-NC-ND 4.0 
praksis, er strategien som antas å ha best potensial for å øke elevenes utbytte av opplæringen (European Commission, 2018). For å bedre praksis, er det viktig at lærerne inngår i ulike samarbeidsrelasjoner med kolleger, med mål om å utvikle praksis (Meld. St. 21 (2016-2017)). Potensialet som faktisk ligger i lærersamarbeid, er imidlertid debattert, og samarbeid i seg selv leder ikke automatisk til læring og forbedring av praksis (Horn \& Little, 2010). Ann Webster-Wright (2009) kritiserer i sin metaanalyse av forskning på profesjonsutvikling hvordan selve begrepet professional development er definert i forskning og praksis, og hevder at vi i stedet for development, dvs. utvikling, må fokusere på loering. I tillegg viser hun til at mange av utviklingsprosessene som igangsettes, er dekontekstualiserte, dvs. at de i læreres tilfelle skjer i en sammenheng utenfor skolen og klasserommet, noe som skaper utfordringer når den nye kunnskapen skal overføres til der de utfører sin praksis. I stedet mener hun at læringen må skje i autentiske omgivelser, og innenfor et fellesskap som støtter læringsprosessene.

Problemstillingen vi skal se nærmere på i dette kapittelet, er nettopp knyttet til læring i autentiske kontekster: Hvordan reflekterer lærere over egen praksis når de blir utfordret gjennom videoobservasjoner fra egen praksis, og hvilke endringer fører det til? Hva lærer lærerne, potensielt sett, gjennom slike prosesser? Før vi går inn på den konkrete casen, vil jeg se nærmere på hvordan lærings- og utviklingsarbeid i lærerprofesjonen beskrives, og deretter vil jeg trekke fram modeller som kan hjelpe oss til å utforske hvordan læringen skjer. Videre vil jeg drøfte bruk av video i endringsarbeidet, før jeg avslutningsvis går over til en case der video var et sentralt hjelpemiddel i læringsprosessen. Casen som benyttes for å eksemplifisere, utforske og beskrive en slik prosess, kommer fra et samarbeid mellom forskere fra Nord universitet og tre Newton-lærere ${ }^{1}$ om å evaluere og videreutvikle en Newton-modul som hadde roboter og matematikk som tema. Prosessen var inspirert av lesson study-tilnærming (Munthe et al., 2015). Video ble benyttet for å dokumentere undervisningen i Newtonrommet gjennom tre ulike runder, og mellomperiodene ble benyttet til å

$1 \quad$ Newton-lærer underviser i STEM-fag i et såkalt Newton-rom, et klasserom spesialdesignet for undervisning i realfag. Newton-rom eies og driftes av skoleeiere som en felles ressurs for skolene i en kommune eller region. Det undervises i ulike moduler som tar for seg kompetansemål for ulike deler av grunnopplæringen. Enkelte Newton-rom har også moduler rettet mot barnehager. 
analysere videoer som grunnlag for å justere og endre innholdet i modulen. I tillegg til videoopptak, ble det også gjort lydopptak av drøftingene mellom lærerne, og mellom lærerne og forskerne, i mellomperioden. Analyse av lydopptakene, sammen med videoopptakene og de læringsressursene som lærerne utviklet (arbeidsark, oppgaveformuleringer osv.), danner det empiriske grunnlaget for casen som presenteres til slutt i kapittelet.

\section{Om læreres profesjonelle læring og utvikling}

Vi vet fra tidligere forskning gjennom flere tiår at svært mye av lærerens praksis er intuitiv og implisitt (Atkinson \& Claxton, 2003; Tomlinson et al., 2010; Webster-Wright, 2009). I det ligger at lærere sjelden redegjør for og begrunner egen praksis, dersom de ikke eksplisitt blir utfordret til å gjøre det. En annen viktig erkjennelse, er at læreres kunnskap og tenkning om praksis, er situert (Lave \& Wenger, 1990), noe som betyr at den som oftest er tett knyttet til egen praksis, og at konteksten har stor betydning både for forståelsen av praksisen, og for hvilke rammer som finnes for endring og utvikling av den (Darling-Hammond et al., 2017; Webster-Wright, 2009).

Forutsetningen for å kunne endre praksis, er at lærere blir bevisste på hva de gjør og hvorfor de gjør det, fordi det er gjennom slike prosesser at den implisitte kunnskapen som lærerne besitter, blir gjort eksplisitt. Gjennom å bli utfordret på hva som ligger til grunn for egen praksis, eksempelvis gjennom å studere egen praksis i form av videoopptak fra undervisningen, kan lærerne bli bevisst hvilke verdier, holdninger, oppfatninger og eventuelt misoppfatninger de har. Gjennom slike prosesser, tett knyttet til egen praksis, legges et grunnlag for å på en systematisk måte kunne justere og endre praksis (Tomlinson et al., 2010). Det er altså gjennom å utfordre implisitte oppfatninger, og stille spørsmål ved praksis som ofte tas for gitt, at læreres læringsprosesser kan medføre faktiske endringer i praksis (Webster-Wright, 2009). Webster-Wright vektlegger at slike prosesser må foregå i lærerens egne omgivelser og omhandle egen praksis, noe hun kaller autentisk profesjonell loering (2009, s. 715). Dette støttes av Darling-Hammond et al. (2017, s. 4), som i sin metastudie vektlegger aktiv læring og lærersamarbeid i reelle arbeidskontekster som sentralt for læreres profesjonelle utvikling. 
Men hva skal til for å kunne oppnå praksisendring? For det første må de som deltar i endringsarbeidet ha noen erfaringer å bygge på, dvs. at de enten må ha utført noe, eller må ha blitt fortalt eller eksponert for noe, som så danner grunnlag for utforsking og læring, det vi ofte kaller for erfaringsloring. Jarvis (1995, s. 415) hevder at all læring kommer fra erfaring, og at læring kan defineres som prosessen med å transformere erfaring til kunnskaper, ferdigheter, holdninger, verdier eller følelser. Han viser til at erfaringer ikke bare omfatter primærerfaringer, dvs. når personene selv er involvert i en situasjon, men også sekundærerfaringer, som omfatter situasjoner der en person blir informert om eksempelvis en prosedyre eller en opplevelse, blir fortalt hvordan det fungerer, og husker det (Jarvis, 1995). Sekundæropplevelser medieres typisk gjennom andre mennesker, men kan også utløses, slik som i vårt eksempel nedenfor, gjennom å eksponeres for videoopptak av situasjoner fra klasserommet.

Hva er det så som kan læres, og som kan resultere i endringsarbeid? En måte å dele inn kunnskap på, er å skille mellom «å vite at» (knowing that) (Ryle, 200o), som omfatter teoretisk kunnskap, og «å vite hvordan» (knowing how), som omfatter kunnskap om praksis i en eller annen form. $\AA ̊$ vite hvordan, er ikke det samme som å inneha en ferdighet; man kan ha kunnskap om prosedyren man må gjennomgå for eksempelvis å kunne starte og kjøre en bil, uten å faktisk kunne utføre det. Det å inneha en ferdighet, kombinert med å vite at og å vite hvordan, er ifølge Jarvis (1995, s. 415) avgjørende for å kunne endre praksis. Ferdigheter kan kun læres gjennom primærerfaringer, mens å vite at og å vite hvordan kan læres gjennom medierte sekundærerfaringer. I tillegg til å vite at og hvordan, trekker Jarvis (1995) fram «å vite hvorfor» (knowledge why), som knyttes til det begrepsmessige rammeverket som en praksis kan bli analysert innenfor, i vårt tilfelle pedagogiske teorier som lærerne kan bruke i sin refleksjon og argumentasjon når de analyserer videoopptakene.

Profesjonsutøvere kan altså lære fra erfaringer, egne eller andres, og i slike prosesser har refleksjon en sentral rolle (Darling-Hammond et al., 2017, s. 4; Webster-Wright, 2009). Ifølge Dewey (1991, s. 8) er refleksjon en måte å tenke på, og til grunn for tenkning ligger tvil, forvirring eller overraskelse; det er noe, eller noen, som setter en tankeprosess i gang (Dewey, 1991, s. 12). Dewey (1991, s. 13) viser også til at reflektert tenkning 
er plagsomt, fordi det forutsetter at vi overvinner tendensen vi har til å umiddelbart akseptere foreslåtte løsninger, og i stedet er villig til å akseptere en situasjon av mental usikkerhet og uro.

Schön (1987, s. 31) utvider Deweys definisjon av refleksjon og beskriver det som «en dialog mellom tenkning og handling som gir meg bedre ferdigheter» (forfatters oversettelse). Gjennom å knytte refleksjon til forbedring av ferdigheter, eller praksis, fokuserer han på det potensialet for forbedring av praksis som ligger i refleksjon. Schön (1991) utviklet begrepene «refleksjon i handling» (reflection-in-action) og "refleksjon over handling» (reflection-on-action), der den forstnevnte omfatter refleksjon som foregår mens man utfører handlingen, mens den sistnevnte omfatter refleksjon over handlingen utenfor den konkrete situasjonen, enten individuelt eller sammen med kolleger. I vårt tilfelle er det den sistnevnte formen for refleksjon som studeres. Thompson og Thompson (2018) tar tak i Schöns begreper om refleksjon i og over handling, og argumenterer på denne måten for refleksjon som en måte å stimulere til endring. De viser til at dersom man klarer å koble disse refleksjonsformene, kan det danne grunnlag for endring av praksis:

Vår refleksjon over handling bør vise tilbake til det vi tenkte på i den faktiske, praktiske situasjonen (refleksjon i handling), slik at neste gang vi er involvert i samme type praksis, så bør vår refleksjon (i handling) trekke veksler på vår tidligere refleksjon over handling. (Thompson \& Thompson, 2018, s. 11, forfatters oversettelse)

Som nevnt ovenfor, må man tørre å utfordre implisitte, men også uttalte, oppfatninger, dersom det skal legges et grunnlag for endring av praksis. Dette kan være utfordrende, og ifølge Webster-Wright (2009) er mulighetene til å utfordre underliggende oppfatninger avhengig av den konteksten profesjonsutøverne inngår i. Er det akseptert at eksisterende praksis og holdninger utfordres, eller er det fokus på ro og konsensus? Lærere som skal inngå i et fellesskap med mål om å utforske og endre praksis, er avhengige av at fellesskapet tillater at spørsmål stilles og at holdninger og verdier utfordres, men innenfor trygge rammer.

Så langt har vi slått fast at læreres tenkning om praksis er situert, ofte implisitt og intuitiv, og må utfordres, slik at tenkningen blir gjort 
eksplisitt gjennom at lærere setter ord på og begrunner det de gjør, fordi det er slik det legges et grunnlag for endring. Bevisstgjøringsprosessen åpner for endring, men endringsprosesser forutsetter erfaringer, fortrinnsvis autentiske primærerfaringer. Her er video et sentralt verktøy for å kunne gjenskape erfaringer i form av videoopptak og gjøre dem til gjenstand for systematiske analyser. Det at lærerne kan inngå i et fellesskap med andre, et fellesskap som har gode rammer for å ta opp forhold som kan oppleves utfordrende, er også viktig. I disse samhandlingsprosessene er refleksjon sentralt, og refleksjon forutsetter at lærerne er villige til å konfrontere egen og andres praksis; villige til å gå inn $\mathrm{i}$ usikkerhet og til å akseptere en situasjon med tvil og uro, hvor det som ofte blir tatt for gitt, utfordres.

\section{Modeller for å stimulere til endring av praksis}

Vi skal nå se nærmere på modeller som kan hjelpe oss å forstå læring i profesjonene, og som er egnet til å stimulere til endring av praksis. David Kolb (1984, s. 21) bygger på både Dewey, Lewin (1948) og Piaget når han presenterer sin modell for erfaringslæring (se figur 1 nedenfor). Modellen tar opp i seg flere av de sentrale elementene som vi så langt har slått fast har betydning for å tilrettelegge for endring av praksis. Den inkluderer konkrete erfaringer, i tråd med Webster-Wrights (2009) fokus på autentisk profesjonell læring; refleksjon, i tråd med Dewey (1991) og Schön (1987); og det å kunne anvende ny kunnskap framkommet gjennom refleksjon i nye situasjoner, i tråd med Thompson og Thompson (2018).

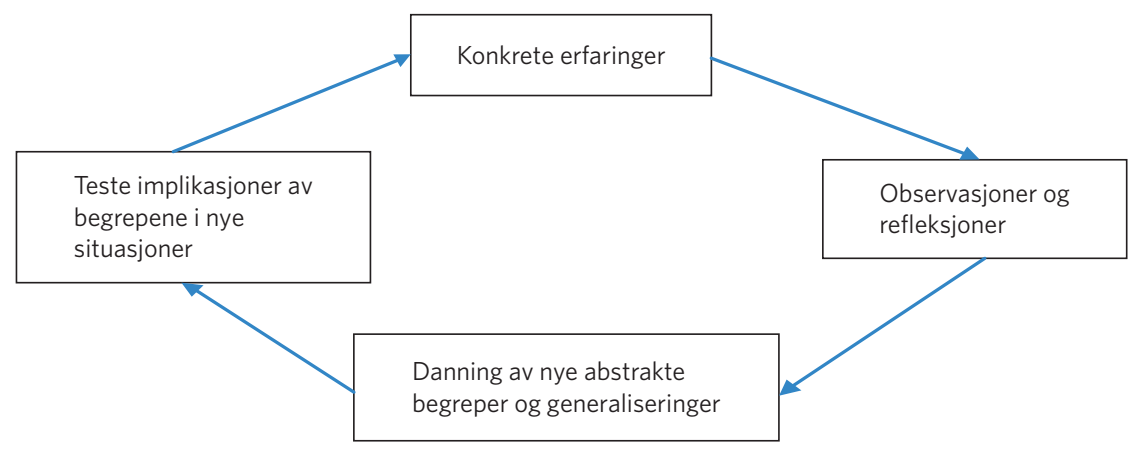

Figur 1. Kolbs modell for erfaringslæring. 
Kolb påpeker at dette er en åpen modell, uten begynnelse eller slutt, der man ser læring som en kontinuerlig prosess. En av utfordringene dersom denne skal anvendes i et lærerfellesskap, er hvordan man tar vare på situasjonene, slik at de kan gi grunnlag for observasjoner og refleksjoner for flere enn den eller de som utførte praksisen som er under utforskning. Her kommer video inn som et sentralt verktøy. Kolbs modell har blitt kritisert (Webster-Wright, 2009) for å være for forenklet, for at refleksjon framstilles som separat fra praksis, og fordi modellen ikke tar inn konteksten. Modellen har imidlertid inspirert pedagogisk praksis, i særlig grad det man ofte betegner som aksjonslæring, eller aksjonsforskning (WebsterWright, 2009). Aksjonsforskning er en kollektiv form for «selvgranskning» som eksempelvis grupper av lærere kan inngå i, og hvor målet er å forstå, utfordre og deretter forbedre eksisterende undervisningspraksis og de kontekstene praksisen foregår i. Aksjonsforskning forutsetter fellesskap og samarbeid, men det er viktig å være klar over at gruppens aksjonsforskning kun kan realiseres gjennom at individuelle gruppemedlemmer får sin praksis kritisk analysert (Kemmis \& McTaggart, 1988, s. 5-6).

Lesson study er en modell for å forbedre praksis i klasserommet, hentet fra Japan, der den har svært lange tradisjoner, og som etter hvert har fått stort gjennomslag i Norge og andre vestlige land. Ifølge Munthe et al. (2015, s. 13) er lesson study «læreres læring satt i system», og den følger opp Kolbs modell (1984), Webster-Wright (2009) og Darling-Hammond et al. (2017) gjennom at læringen foregår i et fellesskap, i autentiske omgivelser, og har observasjon, refleksjon og praktisk utprøving som sentrale elementer. Selv om Kolbs modell ikke lå til grunn da lesson study ble utviklet i Japan, kan hans modell ses på som en integrert del av lesson study-tilnærmingen. I en lesson study-prosess kommer ei gruppe lærere sammen for å planlegge en forskningstime (Munthe et al., 2015, s. 15), der de har valgt ut et element fra praksis som de ønsker å forbedre. Etter at timen er ferdig planlagt, underviser en av lærerne mens de andre observerer, gjerne gjennom videoopptak. Observasjonene danner så grunnlag for felles refleksjon om hva som fungerte bra og hva som eventuelt bør endres. Timen planlegges så på nytt, neste lærer underviser - og slik kan man fortsette gjennom så mange sykluser som nødvendig, inntil man har oppnådd et resultat man er fornøyd med. I mange tilfeller kan prosessen 
inkludere ekstern bistand (Munthe et al., 2015). Olsen og Wølner (2017) trekker linjer mellom lesson study og aksjonsforskning og viser tilbake til Lewin (1948), som ikke bare dannet grunnlag for Kolbs modell for erfaringslæring, men som også regnes for å være "grunnleggeren» av det vi i dag ofte omtaler som aksjonsforskning eller aksjonslæring. Vårt tilfelle, som det redegjøres nærmere for nedenfor, kan betraktes som et eksempel på aksjonsforskning der lærere og forskere i fellesskap samarbeider om å forbedre praksis på en systematisk og forskningsbasert måte.

\section{Video som verktøy i utviklingsarbeid - en case fra Newton-rom}

Etter hvert har bruk av video fått stort gjennomslag innen forskning, og mange tar det også i bruk i utviklingsarbeid, eksempelvis gjennom lesson study. Med den teknologiske utviklingen som har gjort videokameraer små, relativt billige og med god billed- og lydkvalitet, er de egnet til å studere klasseromsaktivitet (Klette et al., 2015). Dersom man har flere kameraer kan man studere hva som skjer på ulike steder i klasserommet på samme tid, eksempelvis aktiviteten til ulike grupper, og man kan studere detaljer som ellers fort blir borte, eksempelvis kroppsspråk eller ansiktsuttrykk. En utfordring med å bruke video, er hensynet til personvern (Blikstad-Balas, 2017; Derry et al., 2010). I vårt tilfelle falt arbeidet innenfor et ordinært forskningsprosjekt, og ble derfor omfattet av forskningsetiske retningslinjer og bestemmelser om innhenting og oppbevaring av datamateriale som kan identifisere enkeltpersoner. Prosjektet var godkjent av personvernombudet for forskning ved Norsk senter for forskningsdata, Universitetet i Bergen. Det å bli filmet kan imidlertid medføre ubehag hos en del deltakere. I eksempelet vårt ble dette minsket gjennom at alle ble utsatt for videoopptak, og dermed oppstod det et fellesskap rundt erfaringene. I tillegg er det viktig at lærerne hadde stort engasjement for og vilje til å forbedre praksis, og tro på at tilnærmingen kunne hjelpe dem. Etiske problemstillinger er imidlertid i like stor grad knyttet til elevene. Alle formelle godkjenninger var på plass, men situasjoner kan oppstå der man må være særlig oppmerksom på den utsatte posisjonen elevene er i, noe som kommenteres nærmere nedenfor. 
I det videre skal vi utforske samarbeid mellom lærere og forskere, inspirert av lesson study, og med bruk av video som et sentralt verktøy for å stimulere lærerne, og forskerne, til refleksjon og læring. Konteksten var et Newton-rom, tre Newton-lærere, to forskere, tre klasser på 6. trinn, og en Newton-modul som lærerne hadde bestemt seg for å revidere og forbedre. Som nevnt innledningsvis er Newton-rom et stort klasserom, eller flere mindre rom, som er designet og utstyrt for å kunne undervise i ulike temaer i STEM-fagene (science, technology, engineering \& mathematics), med bruk av moderne læremidler; læremidler skolene ikke har råd til å investere i på egen hånd. Rommene eies av skoleeier og drives av egne Newton-lærere som har fått opplæring i, og eventuelt også selv utviklet, de modulene som det undervises i på rommet. En Newton-modul er et undervisningsopplegg $\mathrm{i}$ et tema fra ett eller flere av STEM-fagene, og modulene gjennomgår kvalitetssikring før de gjøres tilgjengelige på konseptets nettside, newton.no. Newton-rommene deles av flere skoler i et geografisk område, og modulene gjennomføres ved at elever ved de ulike skolene gjør et forarbeid på hjemmeskolen før de kommer til Newtonrommet, og så er det et etterarbeid når de er tilbake på hjemmeskolen.

Newton-modulene tar opp mange ulike tema fra læreplanene i matematikk og naturfag, og i vårt tilfelle var det matematikk som stod i fokus. Modulen som skulle revideres, het opprinnelig «Roboter og matematikk» og var en mye brukt modul for 6. trinn, men hadde behov for oppdatering. Forskerne som deltok hadde tilgang til videoopptak av undervisning i denne modulen fra et tidligere pilotprosjekt på forskning i Newton-rom, og disse dannet utgangspunkt for samarbeidet med lærerne. Klipp fra opptakene ble studert for å identifisere hva som kunne være aktuelle punkter for revisjon, og man ble fort enige om å bruke gruppearbeid, ikke minst fordi Newton-modulene er bygd opp rundt at elevene skal jobbe med utforskende oppgaver i grupper. Etter en første gjennomgang av opptakene, ble undervisningsopplegget revidert, så underviste en av de tre lærerne ei gruppe elever, og aktiviteten ble dokumentert på video av forskerne. Gjennom bruk av fire ulike kameraer med ekstra mikrofon for å sikre god lydkvalitet, var det mulig å studere hvordan ulike elevgrupper samarbeidet, for å få best mulig innsikt i hvordan gruppeoppgavene fungerte. Forskerne møtte så lærerne igjen, der opptak fra undervisningen 
ble studert, ny revisjon, ny undervisning, ny refleksjon osv. Slik fortsatte samarbeidet gjennom tre ulike runder, inntil lærerne var fornøyd med modulen. Datagrunnlaget som benyttes i beskrivelsen av lærernes refleksjons- og læringsprosess nedenfor, er primært tatt fra lyd- men også noe videoopptak av refleksjonsmøtene som ble gjennomført mellom hver undervisningsrunde. Forskerne publiserte i perioden samarbeidet pågikk en artikkel der gruppearbeid i Newton-rom ble studert (Rusk \& Rønning, 2020), og denne ble delt med lærerne og blir til dels brukt som et teoretisk rammeverk, sammen med lærernes pedagogiske og didaktiske kunnskaper som tas i bruk i drøftingene - det Jarvis (1995) har vist til som «kunnskap hvorfor», dvs. begreper og teoretisk kunnskap om det som drøftes.

På det første samarbeidsmøtet ble det avklart at utviklingsarbeidet særlig skulle legge vekt på å forbedre gruppeoppgavene. Lærerne uttrykker at de ønsker at elevene i større grad enn det de klarer å observere på videoene fra pilotprosjektet, skal ta i bruk matematiske begreper når de snakker. De ønsker å minske tendensen elevene har til «prøving og feiling» uten refleksjon om hvorfor ting fungerer eller ikke, og vil i stedet at elevene skal velge strategier på en mer bevisst måte. De uttrykker også at de ønsker hjelp til hvordan de skal få elevene til å ville fordype seg i fagstoffet og være villige til å gjøre forsøkene flere ganger, uten å stresse for å bli ferdige. Etter å ha studert opptakene fra pilotprosjektet, har de også bestemt seg for at Lego-roboten, som elevene opprinnelig både bygget og brukte i oppgaveløsningen, skal ta mindre plass i den reviderte modulen. Elevene brukte lang tid på å bygge roboten, noe som ikke var i tråd med modulens kompetansemål, så i den reviderte modulen skal elevene få en ferdigbygd robot. Så vil de også, så langt som mulig, fjerne konkurranseelementet i de ulike oppgavene i modulen. Opprinnelig stod konkurranse nokså sentralt i flere oppgaver i modulen, og lærerne observerte på videoopptakene hvordan dette stresset elevene og fikk dem til å primært ha fokus på å bli tidlig ferdig, gjennom mye prøving og feiling, i stedet for å jobbe i dybden med oppgavene. Med dette som utgangspunkt har lærerne jobbet med å revidere modulen, og drøfter i fellesskap hva de vil ha ut av første undervisningsrunde med revidert modul. Lærerne slår fast at modulen har fokus på noen sentrale begreper - omkrets, måling 
og rotasjon, og elevene skal jobbe med disse gjennom tre-fire ulike gruppeoppgaver.

Gjennom å studere opptakene fra refleksjonsmøtene, er der en del temaer som går igjen og som lærerne og forskerne i fellesskap drøfter. Temaene opptrer, i større eller mindre grad, i alle de tre rundene med refleksjonsmøter og påfølgende revisjonsarbeid og undervisning. I det videre presenteres temaene uavhengig av når de opptrådte, og fokus er på hva de handler om, hva som utløser refleksjonen, og hva slags beslutninger som tas om videre arbeid.

\section{Språk- og begrepsbruk}

Lærerne er opptatt av at elevene må ta i bruk sentrale begreper fra modulen, som omkrets og rotasjon. Gjennom å studere opptakene oppdager de imidlertid at elevene ikke nødvendigvis bruker disse begrepene, og at rotasjonsbegrepet kanskje skaper støy, noe som stimulerer en diskusjon blant lærerne. En av dem utfordrer og stiller spørsmålet: «Må vi ha med rotasjonsbegrepet?» Dette følges opp av en diskusjon om betydningen av å bruke matematisk språk eller ikke, og en av dem sier: «Må vi alltid bruke det matematiske språket, eller er det greit å bruke hverdagsspråk i stedet, hvis vi mener det er bedre for elevene?» Diskusjonen avrundes med at de blir enige om at omkrets er så sentralt for læringsmålene i modulen, at det må de holde på, mens når det gjelder rotasjon, konkluderer de med at det er greit å si «runde» eller «antall omkretser» i stedet. Studier av elevenes begrepsbruk på opptakene resulterte på denne måten i en bevisstgjøring av at enkeltbegreper kan skape støy og motvirke læringsarbeidet i stedet for å stimulere det, noe som medfører at lærerne blir enige om at det av og til er greit å avvike fra å bruke matematisk språk, dersom de vurderer at det er til det beste for elevene der og da.

\section{Tidsbruk og fysisk innredning}

Forskerne brukte som nevnt fire ulike kameraer og kunne fange aktiviteten i fire ulike grupper samtidig. Gjennom å studere elevenes aktivitet i gruppene mens de løste den samme oppgaven, framkom det at 
tidsbruken varierte betydelig, fra 3,45 minutter til hele 14 minutter, der den gruppen som brukte mest tid ikke var helt ferdig da lærer avbrøt gruppearbeidet. Denne observasjonen resulterte i en diskusjon om selve oppgaven, og en av lærerne uttrykte at her måtte de se på muligheter for å differensiere oppgaven bedre, eller sørge for å ha ekstra oppgaver til de gruppene som løste oppgaven raskt. Lærerne observerte også at elevene som var tidlig ferdig, skapte en del uro ved at de begynte å leke med stolene og en del læremidler som de hadde tilgang til, blant annet tomstokker. Selv om lærerne nok hadde oppdaget i løpet av økta at særlig stolene, som kunne heves opp og senkes ned, og som man kunne «gynge»på, skapte en del unødig uro, så ble det veldig klart for dem gjennom observasjonen at dette var noe som burde tas tak i. En av lærerne sa: «Her er det til og med en elev som klarer å sitte å gynge på to stoler samtidig! Dette må vi skrive inn i dokumentasjonen om hvordan rommene bør designes, at disse stolene bør unngås.» Det ble også en diskusjon om hvorvidt rommene burde være designet for en spesifikk modul, eller om de burde ha en mer generisk innredning. Det aktuelle rommet var designet med fokus på en energimodul, der det var laget telt for ulike land som hadde ulike muligheter og utfordringer i forhold til ulike energikilder. Hvert land hadde et teppe som, i tillegg til selve teltduken, skilte landet fra de andre, og dette ble benyttet av en enkeltelev for å holde medelever utenfor eller invitere dem inn, noe vi kommer tilbake til i punktet om gruppedynamikk nedenfor. Etter å ha sett nærmere på den fysiske innredningen, uttrykte flere av lærerne at læremidler som tilhører andre moduler enn den som det undervises i, kan skape pedagogisk «støy» for elevene, og at de ville ta denne erfaringen med seg når de skal bidra til design av nye Newton-rom.

\section{Gruppedynamikk}

Mange av refleksjonene handlet om gruppedynamikk. Forhold som ble trukket fram, handlet om sammensetning av gruppene, i hvor stor grad det var reell samhandling i gruppen eller ikke, og hvordan elevene forholdt seg til hverandre. I ett tilfelle oppstod det en litt vanskelig situasjon, etisk sett, fordi lærerne kunne studere hvordan en elev bevisst 
inkluderte og ekskluderte elever fra å ha kontakt med gruppen eleven var en del av. Her ble det før nevnte teltet og teppet som lå på gulvet i teltet, brukt til å ekskludere elever fra andre grupper som ikke var ønsket, mens andre elever ble ønsket velkommen inn. Dette resulterte i en diskusjon blant lærerne om hvordan video kan være en veldig god måte til å studere gruppedynamikk på, men at det også kan utløse etiske problemstillinger som det kan være vanskelig å håndtere. Selv om alle lærerne hadde vært til stede i rommet mens gruppeaktiviteten pågikk, var det ingen som mer detaljert hadde fått med seg prosessene som pågikk i den nevnte gruppen. Det var ikke før man studerte opptakene at det framkom hvor omfattende og ubehagelig ekskluderingen som foregikk faktisk var, noe som også førte til en diskusjon om hvordan man kan forholde seg til dette i ettertid. Burde man ha tatt dette opp med klasselærer? Hvordan skal man kunne hindre at lignende skjer på nytt? Men også: Hvordan kan man forhindre at eleven som stod for ekskluderingen, blir stigmatisert? I slike tilfeller viser sårbarheten ved bruk av video seg i særlig grad, og utløste refleksjoner hos lærerne om hvordan de kunne utvikle en beredskap for å håndtere framtidige situasjoner.

I en av rundene med undervisning i modulen, hadde lærer delt inn i toer-grupper, og alle gruppene bestod av ei jente og en gutt. Videoopptakene viste at i samtlige grupper som ble studert, var det jentene som tok styringen, mens guttene slet med å slippe til. I den gruppen som slet mest og brukte lengst tid, uten å klare å løse oppgaven, kom det klart fram at gutten i gruppa hadde ideer og at han var ukomfortabel med hvordan arbeidet skred fram, men han slapp ikke til. Lærerne diskuterte videre hvordan man kunne gi råd til klasselærer om sammensetning av grupper, men kom til at det var vanskelig. En av lærerne uttalte: «Newton-rommet bør ikke være arenaen der man prøver ut utfordrende gruppesammensetninger. Klasselæreren bør få beskjed om å lage best mulig sammensetning.» Men en av de andre lærerne responderte: «Men det kan godt hende at det var det læreren gjorde, ut fra sine kriterier. Lite støy, lite krangling, jentene tok styringen, og jobben ble gjort. Hva mener vi egentlig med god sammensetning, og hvordan kan vi formidle det til klasselærer?» 


\section{Samarbeidsferdigheter}

Analyse av gruppene reiste spørsmål om samarbeidsferdigheter hos elevene, og følgende spørsmål ble reist: Kan elevene egentlig jobbe i grupper, eller må de forberedes på det når de kommer til Newton-rommet? Dette utløste spørsmål om arbeidet i Newton-rommet burde innledes med en diskusjon med elevene om hva det vil si å jobbe i gruppe, hva man bør være oppmerksom på, hvordan man skal være med hverandre osv. Mens en av lærerne klart uttrykte at dette var forhold som Newton-lærerne var lite flinke til å ta opp, og at det skapte utfordringer, mente en annen av lærerne at det ville ta for mye tid dersom hver modul skulle starte opp med en slik bevisstgjøringsprosess hos elevene. De endte imidlertid opp med å bli enige om å prøve det ut for å se hvordan det virket. I den endelige beskrivelsen av modulen tas forhold vedrørende samarbeidet opp, gjennom å forsøke å bevisstgjøre elevene hvordan de skal kunne nå læringsmålene på best mulig måte (se utsnitt av PowerPoint-bilde nedenfor).

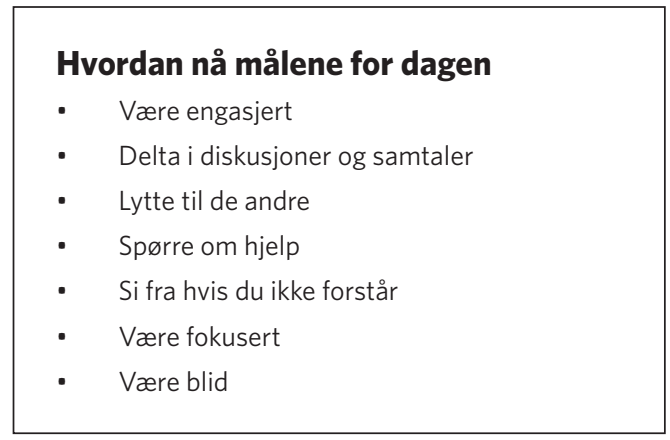

Selv om lærerne ble enige om ei slik løsning, var nok dette ett av de forholdene som framstod som særlig utfordrende, fordi så mye av aktiviteten i Newton-rommene forutsetter at elevene har gode samarbeidsferdigheter og er i stand til å organisere og gjennomføre gruppeoppgaver på en god måte.

\section{Oppgaver, læremidler og valg av strategi}

En vesentlig del av revisjonsarbeidet innebar å studere hvordan elevene løste de ulike gruppeoppgavene. Ble oppgavene forstått, hvilke strategier 158 
tok de i bruk for å løse oppgavene, i hvor stor grad brukte de instruksjonene til oppgavene, osv.? Opprinnelig var enkelte av oppgavene veldig åpne, og lærerne var opptatt av at elevene skulle få mulighet til å være kreative gjennom selv å få delta i utformingen av oppgavene. En av oppgavene var i utgangspunktet veldig åpen og ga rom for kreativitet. Elevene skulle "på fri hånd» teipe opp en figur på gulvet, beregne omkrets og deretter programmere roboten til å kjøre en rute gjennom hele figuren. Denne oppgaven ble nøye analysert. Gjennom å studere hvordan elevene i de ulike gruppene løste oppgaven, ble det nokså klart for lærerne at elevene trengte større grad av regulering i oppgaveteksten, og i de kravene som ble stilt til elevene, dersom læringsmålene om måling og beregning av omkrets fortsatt skulle være i fokus. Fra å være veldig åpen, ble oppgaven betydelig endret. Etter mye diskusjon og noe intern motstand, siden lærerne ønsket at dette skulle være en åpen, kreativ oppgave, ble det i siste runde innført krav om at elevene måtte planlegge figuren og dokumentere denne på et planleggingsark og i en tabell. Siste runde med undervisning viste at avgrensningene av elevenes frihet faktisk ga dem støtte til å løse oppgaven på en bedre måte, mer i tråd med læringsmålene for modulen. De benyttet måleredskaper, de beregnet antall rotasjoner roboten måtte gå for å passere en strekning i figuren, osv. Særlig framtredende var at de i større grad tok i bruk systematiske strategier, i stedet for å kun anvende prøving og feiling, først og fremst fordi oppgaveteksten krevde det. Språket endret seg; de diskuterte strategier i større grad, og de tok i bruk begreper som omkrets, måle osv. Det lærerne tok med seg fra denne delen av arbeidet, var betydningen av hvordan læremidler utformes, hvilken grad av støtte, eller «stillasbygging» (Wood et al., 1976) læremidlene kan gi, og hvordan dette kan påvirke elevenes læringsarbeid.

\section{Elevenes kommunikasjon}

Analyse av videoopptakene ga også mulighet for å studere i detalj måten elevene kommuniserte på. Delte de kunnskaper med hverandre, undret de seg sammen, eller stengte de ned kommunikasjonen gjennom å hevde eller benekte at de hadde kunnskap om det oppgaven gikk ut på? I denne 
diskusjonen mellom forskerne og lærerne trakk en av forskerne fram mer teoretisk kunnskap (vite hvorfor) for å bidra til bevisstgjøring av hvordan ulike kunnskapsmessige utsagn nettopp kan åpne opp for eller stenge ned dialogen:

Når du legger fram og begrunner, så tilbyr du et kunnskapsmessig innhold som andre kan ta tak i og være enig eller uenig i, men hvis du har et mer «fundamentalistisk» utsagn som «Jeg vet!» eller «Aner ikke», så er det ingenting å ta tak i, og dialogen stopper opp.

Dette ga innspill til en diskusjon om hvordan man kunne jobbe med elevene for å få dem til å begrunne forslag til løsninger, eller hvordan man kunne støtte dem gjennom veiledning til å få en mer undrende og mindre fundamentalistisk innstilling til arbeidet. Det sistnevnte leder oss over i det siste temaet som stod sentralt i utviklingsprosessen.

\section{Veiledning}

Newton-lærerne har en sentral funksjon i veiledning av elevenes gruppearbeid. Her er det de som er de viktige fagpersonene, siden klasselærerne som følger klassen ikke nødvendigvis innehar kunnskaper som trengs for å kunne gi målrettet og tilpasset veiledning. Når Newtonlærerne fikk studere egen veiledning gjennom videoopptakene, kom det fram flere ulike refleksjoner. I enkelte tilfeller erfarte de hvordan veiledningen faktisk fikk elevene til å sette ord på hva de tenkte og hvorfor de tenkte slik, mens i andre tilfeller var læreren mer kritisk til veiledningen. I ett tilfelle veileder lærer ei gruppe som strever veldig, og når læreren ser opptaket, kommenterer hun:

Veldig ofte når vi ser grupper som ikke får det til, så gir vi feedback som er for positiv, og det gjør jeg her. Jeg kaller det superbra, og det er det jo ikke! De får ikke tilbakemelding på det de faktisk gjør. Jeg kunne vært mye mer konkret. Overdrevent positiv feedback har motsatt virkning. Jeg ser jo nå at han gutten der, han vet at det de har gjort ikke er bra, og så sier jeg «superbra».

Analyser av andre opptak, der Newton-lærerne kommer inn i gruppene og veileder, får fram at lærerne ikke husker situasjonen, at de ikke husker 
hva de sa eller hvorfor, men gjennom å få tilgang til videoopptaket får de mulighet til å reflektere over egen rolle og, ikke minst, notere seg forhold som de mener de bør forbedre eller videreutvikle.

\section{Avsluttende diskusjon}

Innledningsvis stilte vi spørsmålet: Hvordan reflekterer lærere over egen praksis når de blir utfordret gjennom videoobservasjoner, og hvilke endringer fører det til? Gjennomgangen av casen med revisjon av en undervisningsmodul viser hvordan bruk av video kan stimulere lærere til å reflektere over sentrale elementer i tilrettelegging av og gjennomføring av undervisning og, i neste runde, gjennomføre endringer. Utfallet av samarbeidet mellom forskerne og lærerne gjennom tre runder med undervisning av en Newton-modul, var relativt omfattende refleksjoner omkring forhold som gruppedynamikk, elevers samarbeidsferdigheter, lærers veiledning, hvordan oppgaver var strukturert og formulert osv., og disse refleksjonene resulterte i faktiske endringer i hvordan den nye utgaven av modulen ble bygget opp og dokumentert. De konkrete endringene omfattet særlig oppgaveformuleringene og hvilket støttemateriell lærerne utviklet, men lærerne drøftet også erfaringer som mer langsiktig kan påvirke utformingen av Newton-rommene fysisk, og hvilke læremidler som gjøres tilgjengelig for elevene.

Casen eksemplifiserer anvendelse av Kolbs (1984) modell for erfaringslæring, og det Webster-Wright (2009) definerer som autentisk profesjonell læring, gjennom at lærere anvender primær- og sekundærerfaringer (Jarvis, 1995) fra den konteksten de daglig jobber i, i de drøftingene de inngår i sammen med sine kolleger. Videoopptakene fra elevenes gruppearbeid og lærernes veiledning ga dybde til refleksjonene og diskusjonene gjennom at de hentet fram faktiske situasjoner som ble studert og drøftet i detalj. Opptakene synliggjorde utfordringer i undervisningen som måtte tas tak i, noe lærerne i enkelte tilfeller ikke hadde registrert mens undervisningen pågikk. I andre tilfeller hadde de en fornemmelse av at noe ikke fungerte bra, og da ga opptakene næring til å løfte fram forhold som ellers bare «vaket» i bevisstheten, uten å komme helt opp til overflaten. Opptakene ga på denne 
måten tilgang til at kunnskap og erfaringer som er preget av å være intuitive og implisitte, blir gjort eksplisitte, noe som er avgjørende for å tilrettelegge for læring og utvikling (Tomlinson et al., 2010). Diskusjonene mellom lærerne og forskerne inneholdt til dels en mer teoretisk og analytisk referanseramme, der fokus var på det Jarvis (1995) definerer som «å vite hvorfor», og i slike tilfeller ble pedagogisk og didaktisk kunnskap anvendt for å analysere situasjoner og deretter underbygge analysen.

Videoopptakene gjorde lærerne oppmerksomme på situasjoner som reiser etiske dilemmaer, eksempelvis der en elev bevisst holdt en annen elev utenfor fellesskapet i klassen. Med mange elever og mange grupper å ha oversikt over, kan slike situasjoner være vanskelige å oppdage mens undervisningen pågår. Her ble det veldig synlig i situasjoner som kameraet hadde fanget opp, uten at det var lærere til stede. Denne situasjonen utløste en etisk refleksjon om hvordan denne kunnskapen kunne anvendes. Burde man ta det opp med klasselæreren, slik at det kan følges opp, eller burde man la det ligge og satse på at læreren allerede var klar over hva som foregikk i klassen og hadde strategier for å håndtere det? $\mathrm{Og}$ hvordan forhindre at eleven som stod for ekskluderingen, ble stigmatisert? Dette er etiske refleksjoner som er viktige generelt sett, men særlig når det er snakk om sårbare grupper og, som i vårt tilfelle, barn og unge (Derry et al., 2010).

Casen med bruk av video-stimulerte diskusjoner gjennom en lesson study-inspirert tilnærming viser hvilket kraftfullt verktøy videoopptak kan være for å tilrettelegge for læreres læring og utvikling. Tilnærmingen har helt klart et potensial for å skape vilkår for det Webster-Wright (2009) kaller for autentisk profesjonell læring, men der er også en del utfordringer knyttet til å ta metoden i bruk i læreres felles utviklingsarbeid. Utfordringene handler om kompetanse i bruk av metoden, om tidsbruk, om vilje til å eksponere seg selv og sin undervisning for andre, og vilje til å gå inn i og tåle å stå i det usikre og utrygge. For de skolene og lærerne som tør å ta denne utfordringen, alene eller i samarbeid med eksterne veiledere, ligger store muligheter til utvikling av praksis og dermed bedre vilkår for elevenes læring. 


\section{Referanser}

Atkinson, T. \& Claxton, G. (Red.). (2003). The intuitive practitioner. On the value of not always knowing what one is doing. Open University Press.

Blikstad-Balas, M. (2017). Key challenges of using video when investigating social practices in education: Contextualization, magnification and representation. Research and Method in Education, 50(5), 511-523. https://doi.org/10.1080/ 1743727 X.2016.1181162

Darling-Hammond, L., Hyler, M. E. \& Gardner, M. (2017). Effective teacher professional development. Learning Policy Institute.

Derry, S. J., Pea, B., Engle, R. A., Erickson, F., Goldman, R., Hall, R. Koschmann, T., Lemke, J. L., Sherin, M. G. \& Sherin, B. L. (2010). Conducting video research in the learning sciences: Guidance on selection, analysis, technology, and ethics. The Journal of the Learning Sciences, 19(1), 3-53. https://doi.org/10.1080/10508400 903452884

Dewey, J. (1991). How we think. Prometheus Books.

European Commission. (2018). European ideas for better learning: The governance of school education systems. https://www.schooleducationgateway.eu/downloads/ Governance/2018-wgs1-governance-school_en.pdf

Horn, I. S. \& Little, J. W. (2010). Attending to problems of practice: Routines and resources for professional learning in teachers' workplace interactions. American Educational Research Journal, 47(1), 181-217. https://doi.org/10.3102/ooo283120 9345158

Jarvis, P. (1995). Towards a philosophical understanding of mentoring. Nurse Education Today, 15(6), s. 414-419. https://doi.org/10.1016/so26o-6917(95)80o52-2

Kemmis, S. \& McTaggart, R. (1988). The action research planner. Deakin University Press.

Klette, K., Roe, A. \& Bergen O. K. (2015). Teaching and learning in lower secondary schools in the era of PISA and TIMMS. Springer.

Kolb, D. A. (1984). Experiential learning. Experience as the source of learning and development. Prentice-Hall.

Meld. St. 21 (2016-2017). Lorelyst - tidlig innsats og kvalitet i skolen. Kunnskapsdepartementet. https://www.regjeringen.no/contentassets/71co18d2f5ee 4f7da7df44a6aae265bc/no/pdfs/stm2016201700210oodddpdfs.pdf

Lave, J. \& Wenger, E. (1991). Situated learning: Legitimate peripheral participation. Cambridge University Press.

Lewin. K. (1948). Action research and minority problems. I G. W. Lewin (Red.), Resolving social conflicts (s. 201-216). Harper \& Row.

Munthe, E., Helgevold, N. \& Bjuland, R. (2015). Lesson Study i utdanning og praksis. Cappelen Damm Akademisk. 
Olsen, K.-R. \& Wølner T. A. (2017). Lesson study og loereres loering. Gyldendal Akademisk.

Rusk, F. \& Rønning, W. (2020). Group work as an arena for learning in STEM education: Negotiations of epistemic relationships. Education Inquiry, 11(1), 36-53. https://doi.org/10.1080/20004508.2019.1638194

Ryle, G. (2000). The concept of mind. Penguin Books.

Schön, D. (1987). Educating the reflective practitioner. Jossey-Bass.

Schön, D. (1991). The reflective practitioner. How professionals think in action. Ashgate.

Thompson, S. \& Thompson, N. (2018). The critically reflective practitioner (2. utg.). Palgrave.

Tomlinson, P. D., Hobson, A. J. \& Malderez, A. (2010). Mentoring in teacher education. I B. McGraw, P. L. Peterson \& E. Baker (Red.), International encyclopedia of education (3. utg., s. 749-756). Elsevier.

Webster-Wright, A. (2009). Reframing professional development through understanding authentic professional learning. Review of Educational Research, 79(2), 702-739. https://doi.org/10.3102/0034654308330970

Wood, D., Bruner, J. S. \& Ross, G. (1976). The role of tutoring in problem solving. Journal of Child Psychology and Psychiatry, 17(2), 89-10o. https://doi. org/10.1111/j.1469-7610.1976.tboo381.x 


\title{
Videoobservasjoner og videobaserte samtaler som metoder for kvalitetsutvikling av barnehageansattes spesialpedagogiske praksis
}

\section{Natallia B. Hanssen \& Marit Krogtoft}

\section{Nord universitet}

\begin{abstract}
In Norway, there has been an increasing focus on the importance of the quality of early childhood education and care (ECEC). Several challenges have been identified, including significant criticism of the quality, validity and usability of special educational needs (SEN) practices. This primarily means that kindergarten employees do not seem to be aware of their practices and how their practices can be developed and improved.

The research question in this chapter is how video observation and video-based conversations can contribute to developing the quality of employees' special educational needs practices in kindergarten. The theoretical part of the chapter is based on various approaches, but Jakob Meløe's concept of the 'aware gaze' is the main inspiration.

The data were gathered through video observations and video-based conversations, and the chapter presents two kindergarten employees' SEN practices. Using video-based conversation, they were able to reflect upon and aquire new knowledge relating to their own practice. The results show that it may help to consider inspiring kindergarten employees to use video observation and video-based conversation as meaningful tools to help employees reflect upon their own experiences and practices, thus contributing to the development of high-quality kindergartens.
\end{abstract}

Keywords: video observation, video-based conversation, kindergarten teacher, professional practice

Sitering: Hanssen, N. B. \& Krogtoft, M. (2021). Videoobservasjoner og videobaserte samtaler som metoder for kvalitetsutvikling av barnehageansattes spesialpedagogiske praksis. I F. Rusk (Red.), Videoforskning på ulike leeringsarenaer: Mangfoldig videodata i pedagogisk forskning og utvikling (Kap. 8, s. 165-181). Cappelen Damm Akademisk. https://doi.org/10.23865/noasp.153.ch8

Lisens: CC BY-NC-ND 4.0 


\section{Introduksjon}

I Norge har barnehagefeltet vært - og er fortsatt - i endring. Barnehage og tilbud om barnehageplass har gått fra å være et gode for enkelte til et velferdstilbud til alle. Som en konsekvens av dette har antall barn i barnehagen $ø$ kt betraktelig. Flere barn har fått heltidsplass, og de tilbringer mer tid i barnehagen enn tidligere. Siden 2003, da barnehagereformen påskyndet barnehageutbyggingen, har kvantitet og utbygging blitt prioritert for å realisere målet om full barnehagedekning (Alvestad et al., 2019; Larsen \& Slotten, 2014; St.meld. 24 (2002-2003)). Målet er så å si nådd, og i 2020 hadde 92,2 prosent av alle barn i alderen 1-5 år plass i barnehage, og 84,4 prosent starter før de er 3 år (Statistisk sentralbyrå, 2020).

De senere tiårene har regjeringen blitt mer opptatt av god kvalitet i barnehagen, og har derfor innført et kvalitetssystem som skal bidra til et mer likeverdig barnehagetilbud for alle barn (Kunnskapsdepartementet, 2017; Utdanningsdirektoratet, 2017). Begrepet «kvalitet i barnehagen» er flittig brukt i denne sammenhengen, men kan sies å være et sammensatt og mangefasettert begrep. Undersøkelser av ulike dimensjoner av kvalitet i barnehagen tyder på at de norske barnehagene ikke kan garantere at alle pedagogiske praksiser er av like høy kvalitet (Alvestad et al., 2019; Bjørnestad et al., 2018; Bjørnestad \& Os, 2018; Klette et al., 2018; Nordahl et al., 2018). Det er store kvalitetsforskjeller i det spesialpedagogiske tilbudet i norske barnehager (Hanssen, 2018; Hanssen \& Hansén, 2017; Nordahl et al., 2018; Åmot, 2018).

Variasjoner i kvaliteten i det spesialpedagogiske tilbudet kan blant annet relateres til samspillet mellom ansatte og barn. Dessverre er ikke alle barnehageansatte like gode i dette samspillet (Aukrust \& Rydland, 2009; Bjørnestad \& Os, 2018; Hanssen, 2017). I barnehagen kan det være utfordrende å være konsentrert og oppmerksomt til stede. Man skal gjøre gode vurderinger og ta raske beslutninger, samtidig som aktivitetene glir over i hverandre og man må tolke det barna kommuniserer gjennom både sine ord og handlinger. Og man må legge merke til hva barna opplever som meningsfullt. Samtidig kan det være krevende å møte de konkrete kravene som ligger i praktiske situasjoner, å tilpasse seg til en konkret situasjon, og å ha blikk for hva som er mulig i situasjonen, hva som kan forandres og varieres (Bjørnestad, 2019; Bjørnestad \& Os, 2018; 
Hanssen, 2017). Ifølge Nordahl og Hansen (2015) vil det alltid være et potensial for å heve kvaliteten på tilbudet. Forfatterne mener at kvalitetsheving først og fremst går ut på å øke barnehageansattes bevissthet over egen praksis.

\section{Barnehageansattes bevissthet over egen praksis}

Fossestøl (2011) fremholder at bevisstheten over egen praksis må erfares og ofte møysommelig opparbeides, og at den også kan være vanskelig å tilegne seg. Hun understreker at det kan ta tid å etablere trygghet, kyndighet og evne til en systematisk bevissthet over egen praksis. Fossestøl (2011) skriver videre at det kan tenkes at et høyt bevissthetsnivå vil kunne åpne muligheten for å se situasjonen fra ulike perspektiver, fange opp nyanser og kompleksitet i en tilsynelatende «alminnelig» situasjon, samt å kunne foredle egen personlig forståelse og egen tolkning av praktiske erfaringer. På bakgrunn av dette kan man stille spørsmålet: Hvordan kan en slik bevissthet økes når det gjelder de ansatte i barnehagen?

Flere studier viser at barnehageansatte kan bli kjent med seg selv og bli bevisst egen praksis på mange måter. Én måte å gjøre dette på, er gjennom refleksjon. Moxnes (2016) viser at refleksjonsbegrepet er mangefasettert og komplekst. Forfatteren mener at personlig endring og ny erkjennelse er en fellesnevner for refleksjon. Flere andre forskere peker på at refleksjon innbyr til å innta en metaposisjon i forhold til egen praksis og dens utfordringer (Brekke \& Eide, 2019; Klemp, 2013; Postholm, 2008; Schön,1983). Det er altså store variasjoner i hvordan refleksjon forstås. Vi tar utgangspunkt i Moxnes (2016), som skriver at det kreves grundige forberedelser for studenter i barnehagepraksis hvis refleksjon skal ha betydning. I det følgende antar vi at dette er like relevant for ansatte.

En annen måte å etablere bevissthet over egen praksis på, er gjennom observasjon, iakttakelse eller undersøkelse (Frønes, 2017; Løkken, 2012). Det finnes ulike former for observasjon, og i barnehagen brukes de for å fange opp prosesser som skjer i den pedagogiske praksisen (Frønes, 2017; Løkken, 2012). I en barnehagesammenheng er observasjon også en grunnleggende forutsetning for de ansattes arbeid med pedagogisk dokumentasjon i hverdagen (Frønes, 2017). Observasjon utføres vanligvis 
ved iakttagelse, der observatøren ser, og noterer det hun/han ser samtidig eller etterpå. Dette gir observasjoner som er fremstilt verbalt.

Men videoobservasjoner fremstilles både gjennom ord, bilder og bevegelser. Arbeidet med videoobservasjon kan lede til sterkere og bedre refleksjon, samtidig som videoobservasjoner fanger mer enn ord kan si (Knoblauch et al., 2006). Fordeler med video er at den gir mulighet til å studere fenomenet $\mathrm{i}$ et holistisk perspektiv, avbilder nærvirkeligheten på en mer kompleks måte og lar hendelser og situasjoner tale for seg selv (Knoblauch, 2008). Det betyr at video ikke kan reduseres til lingvistiske utrykk alene. Videoopptakene gir også mulighet til å studere de meningsfulle nonverbale utrykkene (smil, gester, blikk, bevegelser, toneleie m.m.) mellom deltakere i rommet, samtidig som man får en innsikt i det miljøet som kommunikasjonen og samhandlingen foregår i (Cohen et al., 2011;Valle, 2018). Dette holistiske perspektivet og nærheten til aktiviteten åpner også opp for å studere detaljer som aktørene selv ikke er seg bevisst (Valle, 2018). For eksempel den tause siden ved praksis; den intuitive innsikten som er underforstått og som ikke kan formuleres eksplisitt, det som er «avleiret i innøvde kroppslige ferdigheter og fortrolighet med omgivelsene, og i mindre grad i språk» (Grimen, 2008, s. 79).

En annen fordel med video er at opptaket kan spilles flere ganger og nyskapes dersom en er på jakt etter alternative tolkninger eller tolkninger å enes om (Løkken, 2012). I tillegg kan video gi et godt grunnlag for samtale og refleksjon over hva som skjedde i den observerte praksisen (Løkken \& Søbstad, 2013). Gjennom en slik videobasert samtale kan man diskutere ulike handlingsvalg og analysere mulig forbedringspotensial av ens egen yrkesrolle (Knoblauch et al., 2006). Dessuten er aktørenes erfaringer med å få reflektere over egen praksis mens de ser på opptak og samtaler, vesentlig for å utvikle faglig visdom (Kemmis \& Smith, 2008, s. 32).

Ifølge Valle (2018) er aktørens tolkning av egen praksis et sentralt aspekt ved bruk av videobaserte samtaler. Videobasert samtale bringer inn nye perspektiver på hvordan praksisen kan forstås med utgangspunkt i informantenes tolkning. Nye perspektiver utfordrer aktørens etablerte bilder av seg selv og deres syn på praksis. Via diskusjonen av videopptak legges det til rette for at aktørene kan få erfaringer med å 
analysere sin egen rolle kritisk for å overskride egen forståelse (Moxnes, 2016). Målet er å utvikle autonome barnehageansatte som har en tryggere faglig selvforståelse med hensyn til hva det vil si å håndtere utfordringer i det spesialpedagogiske tilbudet, kort sagt kunne være i stand til å utøve dømmekraft (Fossestøl, 2011).

Det er påfallende at flere påpeker at bruk av videoobservasjon og videobaserte samtaler kan bidra til en tryggere faglig selvforståelse hos barnehageansatte med hensyn til hva det vil si å håndtere utfordringer i barnehagepraksisen (Løkken, 2012; Løkken \& Søbstad, 2013)). Paradoksalt nok synes det å være gjennomført relativt få studier av hvordan barnehageansatte bruker disse metodene som et redskap for å få bedre kjennskap til seg selv i en gitt kontekst, spesielt i den spesialpedagogiske praksisen.

Derfor setter vi i denne teksten søkelyset på bruk av videoobservasjon og videobaserte samtaler som metoder, og diskuterer følgende problemstilling gjennom empiriske eksempler: Hvordan kan bruk av metodene videoobservasjon og videobaserte samtaler bidra til kvalitetsutvikling $i$ barnehageansattes spesialpedagogiske praksis?

\section{Videoobservasjon og videobaserte samtaler - blikket som redskap}

Når barnehageansatte observerer seg selv (med video som hjelpemiddel) og overveier om de skal bruke det de observerer videre (i videobaserte samtaler), har de en observerende væremåte rettet mot seg selv i hverdagen.

Med utgangspunkt i den observasjonen man gjør av seg selv, kombinert med videobaserte samtaler og refleksjoner, får den enkelte kjennskap til seg selv på en ny måte. I denne observerende væremåten er blikket det viktigste redskapet.

Jakob Meløe (1983) har også skrevet om blikket. Ulike blikk styrer hva vi ser, hva vi legger merke til. Meløe (1983) snakker om tre ulike blikk, men vi skal ta for oss bare ett av dem; det kyndige blikk. Det kyndige blikk er blikket til den som forstår virksomheten og er innenfor virksomheten som deltaker. Meløe (1983) eksemplifiserer dette med den forbipasserende observatøren som legger merke til at svart løper truer hvit dronning i et parti sjakk. Observatøren har her et kyndig blikk, fordi å se at løperen truer 
dronningen krever kunnskap om sjakk og om spillets regler. På samme måte ville en observatør uten kunnskap om fotball, kunne beskrive det som en aktivitet der 20 menn løper etter 1 ball, mens en fotballfan kanskje ville se både samarbeid og konflikter, eleganse og godt fotarbeid.

Det å bringe begrepet kyndig blikk frem både i observasjonene og i samtalen om det man ser, vil kunne hjelpe barnehageansatte å danne et utgangspunkt for bedre forståelse av seg selv i sin yrkesutøvelse.

\section{Datainnsamling - barnehageansatte som deltok}

For å drøfte hvordan videoobservasjon kan bidra til en slik bedre forståelse, tar vi utgangspunkt i videoer som er brukt i forbindelse med et annet forskningsprosjekt der videoobservasjon ble valgt som instrument for datainnsamlingen (Hanssen, 2018). Dette utvalget ble rekruttert fra fem ulike barnehager, og omfatter én mann og fire kvinner i alderen 40-60 år. Tre av informantene er barnehagelærere med 3-årig høgskole- eller universitetsutdanning. Én av disse tre hadde i tillegg en 1-årig etterutdanning i spesialpedagogikk fra høgskole-/universitetsnivå. De to øvrige informantene hadde utdanning på videregående skoles nivå. Alle arbeidet til daglig i offentlige barnehager med barn som av ulike grunner hadde fått innvilget spesialpedagogisk hjelp. Barnehagene hadde totalt mellom 26 og 120 barn hver.

Observasjonene i barnehagene foregikk over en periode på rundt tre uker. Med hver ansatt ble 4-6 spesialpedagogiske aktiviteter videofilmet. De observerbare spesialpedagogiske aktivitetene ble organisert både som individuelle og gruppeaktiviteter. Gruppene var omtrent like store: fire til seks barn, og de inkluderte også andre barn uten spesielle behov.

Kameraet som ble brukt, var et avansert vidvinkelkamera'. Kameraet ble montert på et stativ og plassert på gulvet bak i rommet, både for å unngå forstyrrelser og bakgrunnsstøy og for å få en optimal oversikt. En av forfatterne sto bak og ved siden av kameraet for å overvåke filminga.

1 Den brede vinkelen gjorde det mulig å fange nesten hele rommet fra én posisjon, mens den innebygde mikrofonen (og bruken av det adaptive mangfoldsprinsippet) gjorde det mulig å fange stemmer med forskjellige volum uten behov for små, trådløse mikrofoner festet til kroppene til informantene. 
Fokus under videoobservasjonene var rettet mot å få relevante beskrivelser av hvordan aktivitetene var organisert, hvordan de ble gjennomført og hva som foregikk. Etter at relevante videoscener for å belyse problemstillingen ble valgt, ble de barnehageansatte invitert til å se på utvalgte videoklipp sammen med en av artikkelforfatterne og gi sin forståelse og tolkning av scenene. Informantene ble bedt om å snakke om hva som skjedde på videoopptaket, samt hvordan de ville beskrive, forklare og forstå situasjonen og hendelsene. De ble også bedt om å beskrive flere andre eksempler fra lignende situasjoner. Videoobservasjoner og videbaserte samtaler ble transkribert i sin helhet og deretter analysert med utgangspunkt i artikkelens problemstilling.

Vi analyserte data gjennom stadig veksling mellom del og helhet for å utvide forståelsen i forhold til konteksten, og for å finne sannheten (Gadamer, 2003). Denne prosessen baserer seg på bevegelse mellom det som er forstått og det nye, mellom deler og helheter, mellom det som blir fortolket og vår forforståelse (Gadamer, 2003). Transkripsjonene fra videoobservasjonene og transkripsjonene av samtalene med de ansatte ble lest på nytt, for å få en helhetlig følelse av det innsamlede datamateriale. Dessuten ble videoene sett på nytt, og lydopptaket hørt på nytt for å forsikre oss om at vi hadde med den originale konteksten. Basert på det analysearbeidet, ble to korte scener fra videoobservasjoner og to samtaler med informantene om disse scenene valgt ut.

I det følgende presenteres de to videoscenene med tilhørende samtaler med informantene. Samtidig reflekterer vi over noen betydningsfulle nyanser som disse scenene viser, og ser dem i lys av teoretiske perspektiver presentert tidligere. For å følge forskningsetiske prinsipp om anonymitet, bruker vi fiktive navn på både barnehageansatte og barn. I tillegg, for at deltakerne ikke skal bli indentifisert på grunn av sin dialekt, gjengis scenene i bokmålsform.

\section{Jeffly}

La oss tenke oss at vi kommer inn i grupperommet i en barnehage. Det er desember og halvmørkt ute. Alt inne er pyntet til jul, men rommet vi kommer inn i, ser nakent og trist ut. Rommet er veldig trangt, bordet 
er så stort at det tar nesten hele rommet. Det er fire stoler rundt bordet. Sander, 5 år, setter seg ned på en stol og venter. Han får spesialpedagogisk hjelp på bakgrunn av antatte språkvansker, men han har ikke en formell diagnose (fordi man som regel ikke gir formelle diagnosene på barn i førskolealder). Sander er veldig sjenert, han snakker utydelig og er til vanlig motvillig mot å delta i lek og andre sosiale interaksjoner med både barn og voksne. Samtidig fremstår han som en fornøyd, trygg og likevel deltakende gutt. Anja, en barnehagelærer som også er én av de informantene, kommer inn. Hun setter seg ned, ser på Sander og sier med tydelig og sikker stemme: «Nå skal jeg og du ... hva skal vi? [stopper, ser på barnet] Er du klar? Skal vi bare begynne med en gang?» Sander nikker og sier «ja». Anja begynner å bla i mappene sine og åpner en: «I dag er det den 5.» Hun skriver det ned, blar i mappa si. Henter så et speil, tar frem både kort og hermeboka. Sander sitter stille og venter, titter av og til ut av vinduet. Så starter de å spille lotto, de trekker kort med ord som starter på J og F, og finner første lyden i ordet. Så uttaler de ordene tydelig og legger kortet på brettet (fot, fisk, jojo, jente).

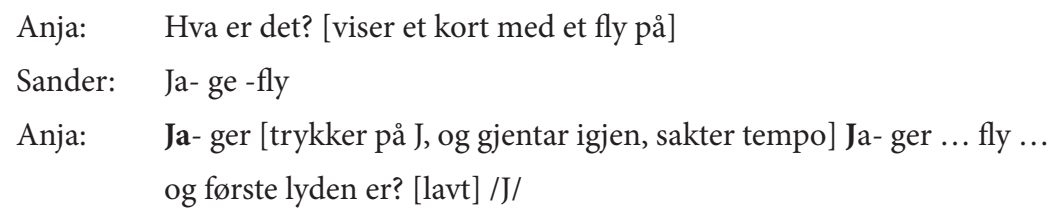

Anja kommenterer og forklarer aktiviteten (når vi sammen ser på dette opptaket etterpå): «Jeg snakker sakte. Og deler veldig sånn ... ja-ger-fly.» Hun forteller videre at for ett år siden snakket Sander enda mer uklart og veldig fort, og da ble størsteparten av ord borte. «Jeffly [altså jagerfly], det skulle vært sånn som han pratet for et år siden.»

Gjennom videoobservasjoner er det rimelig å anta at Anja kjenner spesialpedagogisk praksis godt, og har erfaringer med den. I denne scenen, og i samtalene med Anja, kan man oppleve ulike elementer som alle er essensielle for å anta at Anja er «kyndig»: fortrolighet med seg selv og det hun gjør, og trygghet, også i forhold til aktørene (i dette tilfelle barn). Hun har valgt oppgaver som passer for barnet, hun virker trygg og sikker både i ord og bevegelser. Og det virker som om barnet venter tålmodig, 
også trygg, situasjonen er kjent og Anja er rutinert. Videoscenen tyder på at med det kyndige blikket sees og forstås den spesialpedagogiske praksisens koreografi lettere. Anjas kyndighet i den spesialpedagogiske praksisen som hun er en del av, later til å bidra til å styrke både mestringsfølelsen og selvbildet hennes, noe som motiverer henne for videre innsats i det spesialpedagogiske arbeidet med barna.

Gjennom den videobaserte samtalen forteller Anja at hun tror hun vet hva og hvordan det skal jobbes når det er snakk om barn med språkvansker. Hun påpeker:

Jeg kommer ikke hit inn og setter meg ned og tenker på at nå må du Anja ... det tenker jeg ikke. Men det blir liksom ... når jeg får det materiellet der foran meg så vet jeg hva det er ... det er på en måte innarbeidet, at du ikke tenker på det du gjør. Det kommer av seg selv ...

Som det går frem av sitatet ovenfor antar Anja at hun med sitt kyndige blikk lett kan se både egne, barnas og den spesialpedagogiske praksisens utfordringer, og at hun lett kan sette i gang ønskede løsninger i den praksisen. Sitatet gir oss grunnlag for å tolke Anja dit hen at hun er trygg på at hun gjør en god jobb, og at hennes kyndighet er en ressurs. Ved å bruke denne ressursen på riktig måte, utvikles det dybde, kvalitet og fortrolighet til praksis (Klemp, 2013).

Å øve opp et kyndig blikk er en verdifull strategi som kan bidra til å fange opp kompleksiteten og nyanser i egen praksis, samt utforske utfordrende forhold (Frønes, 2017; Meløe, 1983; Moxnes, 2016). Og hvordan kan en øve opp et kyndig blikk og anvende det inn i ens praksis? Som nevnt tidligere i kapitlet, kan videoopptak gi et levende inntrykk av hva som skjer i praksis, og barnehageansatte kan gjennom flere gangers avspilling analysere egen praksis grundig (Løkken \& Søbstad, 2013). I tillegg kan tolkning av egen praksis via videobaserte samtaler bringe inn nye perspektiver og gi ansatte forståelse som grunnlag for å øve opp kyndig blikk over praksisen (Valle, 2018).

Samtidig, når barnehageansatte etterstreber det kyndige blikket i sin tilnærming til egen praksis, kan også faren være at barnehageansatte vil lage forhåndsdefinerte kategorier og følge fastlagte oppskrifter når de skal vurdere og reflektere rundt sin praksis (Frønes, 2017; Grimen, 2008). 
Barnehageansattes kyndighet har nemlig sammenheng både med deres utdannelse og med ulike både individuelle og kollektive erfaringer som de har fra yrkesliv (Hanssen, 2017, 2018; Nordahl \& Hansen, 2015). Det betyr at ansatte reagerer, handler, reflekterer og ser på bestemte måter i møte med andre. Det kan antas at deres utvikling av kyndig blikk baseres på holdninger, erfaringskunnskap og tradisjoner innenfor ens egen kulturs lukkede rom (Wackerhausen, 2008). Ved å bevege seg rundt i et selvbekreftende og beskyttende erfaringsrom, risikerer barnehageansatte å utvikle kyndighet basert på allerede eksisterende «sanntroende» kunnskaper, holdninger og tradisjoner, samt reflektere rundt situasjoner der det tenkes med egne tradisjoner, med egne begreper og ut fra egne tradisjonelle perspektiver. Det gjenkjennelige blir noe som blir lagt merke til, og blikket vil styres mot dette (Frønes, 2017). Et kritisk moment ved dette er at det kyndige blikket vil fungere som et slags filter som tar bort nyanser fra egen praksis og er med på å dyrke etablerte sannheter i praksis, fremfor kritisk undring og nytenkning (Ødegård, 2011). Faren i en slik kyndighet handler om at det ikke åpnes opp for nye sannheter, det er vedtatte sannheter som blir bekreftet i møtet med egen praksis gjennom videoobservasjoner og videobaserte samtaler. Det følgende eksempelet fra videoopptak i barnehagen illustrerer dette poenget; at det kyndige blikket er blitt et filter for egen forståelse av praksis.

\section{Hjelpeord}

Videoopptaket fra barnehagen viser rommet, som er forholdsvis stort. Mye forskjellig pynt på veggene. Barna sitter i en krok som er avgrenset med bokhylle og sofa. Det er flere dører som går ut til andre rom, og det er stadig andre barn og voksne som går inn og ut av rommet. Ole, som er barnehagelærer, gjør seg klar til spesialpedagogisk aktivitet, småløper rundt, rydder rommet, setter bordene og stolene på plass. Ole starter med Alias (ordforklaringsspill for barn). Barna trekker kort, ler, prøver å gjette ord, noen forklarer ordene godt og får mye ros av Ole: «Det var godt forklart! Du er flink!»

Petter, en gutt på 5 år som får spesialpedagogisk hjelp på bakgrunn av antatte språkvansker, men, som i likhet med Sander over, ikke har en 
formell diagnose, deltar ikke aktivt i spillet. Petter har spurt om å også få trekke kort, men måtte vente ganske lenge, og nå er det endelig hans tur! Han står ved siden av Ole, holder kortet, øynene glitrer og han virker stolt. «Du må gi dem noen hjelpeord», instruerer Ole, «du må ikke si ordet ... jeg kan holde kortet slik at de ser ikke ... gi dem hjelpeord, er det dyr eller? Si det høyt, du må si det høyt!» Petter hvisker noe i Oles øre. «Du må ikke si det ordet», sier Ole, «du må si noen hjelpeord!» Petter prøver (han har et kort med en papegøye): «det er en sånn, en sånn ... en sånn, nei ... en sånn flyr på tre ... ikke drage ... det begynner på gy .... gy» (vifter med armene og imiterer vinger).

Ole: Ja, men det ... du må hjelpe litt her [tar ansiktet til Petter med sine hender og snur det mot seg selv] du må se på meg, sånn ... du må hjelpe dem ... du sa den kan fly på tre ... det må kanskje være en fugl?

Petter: [nøler] Nei ...

Ole: $\quad$ Men det er bare fugler som har vinger?! Hva er det slags fugl?

Petter: Det er ... det er faktisk ... dere må si det hva er det [han henvender seg til andre] vet dere hva det er?

Ole: [gjentar] Du må gi dem ord ... [og slik fortsetter det]

Vår tolkning av filmen er at valget av spill, Alias, og ikke minst måten det ble gjennomført på, ikke var en god arbeidsmåte for barnet som har utfordringer med språk. Det virker som at hele hendelsesforløpet resulterte i en helt uforståelig og uinspirerende aktivitet for gutten. I den videre tolkning av scenen ser det ut til at Ole ikke var bevisst og oppmerksom på det som skjedde, og konsentrerte seg kun om utøvelsesprosessen. Det virker som om at Petter ikke ble møtt på opplevelsesaspektet, altså det å kunne være litt stolt av å være med på leken, og mestre den på sitt nivå.

Samtidig virker det som at Ole føler seg trygg, han har erfaring med å arbeide med barn, og han er kyndig og fortrolig i det han gjør. Med utgangspunkt i episoden kan vi antyde at Oles blikk på egen praksis blir et filter hans fagkunnskap siles gjennom, og derfor har han ikke klart å vise sensitivitet med hensyn til hvordan han burde handle i denne situasjonen. Med andre ord, den voksne har ikke sett at utfordringen ligger i ham selv, i hans måte å organisere og gjennomføre denne praksisen på. 
For å initiere ny innsikt og samtidig gi mulighet til å kritisk granske Oles praksis i møte med Petter, ble videobasert samtale brukt. Da denne episoden med Ole ble diskutert i etterkant av at vi hadde sett opptaket, fremsto han plutselig som forvirret og fortalte at han egentlig nå legger merke til det som har skjedd. Ole kommenterer:

Jeg er bevisst og jeg visste at dette her ... det grudde jeg meg til å se, for jeg vet at det der ... den der oppgaven ... nei, det der var jo helt ute av... jeg ser jo egentlig hvor lite kontroll jeg har. Jeg trodde ... jeg hadde jo en snev ... at jeg hadde kontroll, men jeg ser jo her at det er jo helt [...] Nei altså det ... jeg ser jo at det er jeg som ... altså, jeg ser jo at jeg gjør en feil [...] Det er jo en refleksjon det der altså, å se i ettertid, ja.

Oles beskrivelser tyder på at uten muligheten til å se seg selv «utenfra» og deretter å samtale på bakgrunn av det opptaket, ville det vært krevende å fange opp og ikke minst å gjenkalle den konkrete situasjonen hos han. Som forklart tidligere i dette kapitlet, kan det kyndige blikket endres tilå bli et filter - det er fast, bekreftende og ubevegelig, og det kan være utfordrende å rive seg ut av etablerte handlingsmønster og kunne se og reflektere rundt det som foregår fra et «utenfra-perspektiv» (Postholm, 2008; Wackerhausen, 2008; Zeichner \& Liu, 2010). I denne sammenhengen risikerer barnehageansatte å miste det innovative, det kreative blikket, evnen til å skape noe nytt, og muligheten til å bevege seg innenfor den kreative, skapende virksomheten.

Likevel, gjennom bruk av videoobservasjon kunne Ole få nye perspektiver på - og utfordre - egen praksis. Ved å reflektere sammen over disse observasjonene, ved hjelp av videobasert samtale, fikk Ole muligheten til å løfte frem ulike stemmer og sannheter og utvikle en bedre bevissthet over eget praksisfelt. Det er krevende, fordi en må bevege seg ut av det vanlige, til det fremmede, ut av selvfølgeligheter, noe som innebærer at en blir fremmed og ukjent for seg selv. Og den bevegelsen fasiliteres av videoopptaket og gjensynet med episodene - og samtalen rundt dem. Allikevel er den bevegelsen helt nødvendig i en tid der barnehageansatte må møte de konkrete kravene som ligger i praksis, å tilpasse seg til en konkret situasjon, og å ha blikk for hva som er mulig i situasjonen, hva som kan forandres og varieres. Med andre ord 
etterstrebe kvalitet i praksisen sin (Bjørnestad, 2019; Bjørnestad \& Os, 2018; Hanssen, 2017).

\section{Avsluttende tanker}

I dette kapitlet har vi antydet noen sentrale poeng som kan være verdifulle med tanke på å kvalitetssikre barnehageansattes spesialpedagogiske praksis. På bakgrunn av funnene er det rimelig å anta at dersom barnehageansatte skal ha muligheter til å studere seg selv, er blikket noe som bør utvikles, og i den sammenhengen er videoobservasjon og videobaserte samtaler nesten helt nødvendige og uvurderlige hjelpemidler for å få nye perspektiver på - og å kunne utfordre - egen praksis.

Når dette er nevnt, er det også et viktig poeng å dvele ved spørsmålet om hvorvidt disse metodene gir grunnlag for mer enn dybdetenkning. Moxnes (2016) beskriver i sin undersøkelse at det kanskje må være en tidkrevende og gradvis prosess til for å komme videre og dyptgripende i praksis som skal endres og forbedres. Samtidig kan bruk av videoobservasjon og videobaserte samtaler sette i gang forsvarsmekanismer når ansattes praksiser og forståelser blir utfordret. Men dersom barnehageansatte får øynene opp for at dette dreier seg om spesialpedagogiske problemstillinger og kvalitet i barnehagen, vil det kunne skapes muligheter for endring (Brekke \& Eide, 2019).

Et annet viktig poeng er at bruk av de omtalte metodene generelt, og særlig videoobservasjon, stiller store etiske krav. Løkken (2012) viser til behovet for å se aktørens anonymitet og konfidensialitet som en del av etisk forpliktelse. Selv om formålet er en forbedring av ansattes praksis, skjer den praksisen alltid i en kontekst, gjennom samhandling med barn (Hanssen, 2017; Åmot, 2018). Det innebærer at ulike sider ved barn, sider som ikke den enkelte ansatte alltid får med seg om barnet, kan tre tydeligere frem. Derfor er det vesentlig å etterstrebe at ikke noen føler seg utlevert, eller at deres anonymitet blir ubeskyttet (Knoblauch et al., 2006). Det må være klare avtaler på forhånd dersom et opptak av barn skal gjøres og vises for andre. Løkken (2012) mener at så lenge de formelle avtalene er gjort, kan videoobservasjoner være verdifulle eksempler som kan bidra til at ansatte lærer av seg selv, av hverandre og i fellesskapet. 
I den etiske vurderingen, som for øvrig må foretas kontinuerlig, kommer en dessuten ikke utenom det faktum at barnehageansatte kan være redde å dumme seg ut, fremstå som inkompetente eller føle seg brydd (Løkken, 2012). Derfor er det viktig at i situasjoner hvor ansattes egen praksis utfordres, må det tidlig utvikles en aksepterende kultur og miljø hvor barnehageansatte får være åpne i både gi og ta imot kritikk (Brekke \& Eide, 2019).

Et tredje viktig poeng som kan trekkes frem, er hvordan de ansatte i barnehagen kan jobbe med videoobservasjon og videobaserte samtaler. Observasjon og samtaler er omfattende metoder som krever mye kunnskap, og det er av betydning at de ansatte først og fremst bør jobbe med forståelse av begrepene, videre med planlegging og gjennomføring av observasjoner og samtaler, samt analyser og videre praktisk arbeid som kan bidra til bedre yrkesutøvelse. Det er selvsagt vanskelig å gi en oppskrift på hvordan arbeidet skal planlegges og gjennomføres, men arbeid i den rekkefølgen som her antydes kan passe for noen (Frønes, 2017; Løkken \& Søbstad, 2013).

Et fjerde vesentlig element gjelder betydningen av å jobbe kontinuerlig og systematisk med videoobservasjon og videobaserte samtaler for å opprettholde bevisstheten rundt viktigheten av dette arbeidet i hverdagen. Frønes (2017) påpeker at i barnehager hvor observasjonsarbeidet er satt $\mathrm{i}$ system, forteller de ansatte at dette bidrar til at de lærer av hverandre og $\mathrm{i}$ fellesskapet. Vi vil videre understreke at selv om anvendelsen av metoder er satt i system, er de kanskje ikke til mye hjelp hvis de ikke gjennomgående knyttes til systematisk oppfølging av ansatte. Det er nødvendig å presisere hvem som skal gjennomføre videoobservasjon og samtaler i barnehagene. Skal det være et lavterskeltilbud der ansatte selv skal utfordres til å anvende disse metodene og i fellesskap utvikle personalgruppas forståelse for praksis, eller skal en invitere observatører utenfra? Uansett hva man velger, krever det grundig arbeid, gjennomtenkning og planlegging, kanskje til å begynne med som deltakere i et forskningsprosjekt (Hanssen, 2018; Knoblauch, 2008; Valle, 2018).

Det fjerde viktige elementet berører prosessene etter er opptaket startet. Dette vil være knyttet, som tidligere nevnt, til hvordan barnehageansatte innenfor gitte rammer og etablerte kulturer innen den institusjonen som 
barnehagen er, blir i stand til å avdekke (eller å se) seg selv i hverdagens hendelser (Fossestøl, 2011; Meløe, 1983). Moxnes (2016) viser til at erfarne ansatte ikke nødvendigvis klarer å artikulere og demonstrere egne refleksjonskunnskaper i slike situasjoner. Det er nødvendig å tilrettelegge både for muligheten til å stille kritiske spørsmål, å synliggjøre ulike perspektiver og å tørre å stille spørsmål ved barnehagens rammer og kulturer.

Hvorvidt barnehageansatte kan tørre å stille spørsmål og ta i bruk evnen til å se seg selv, vil avhenge av relasjoner mellom ansatte og av viktigheten av at prosessen ledes av personer deltakerne har tillit til (Aukrust \& Rydland, 2009; Bjørnestad \& Os, 2018; Løkken, 2012). Men det er ikke nok; både å stille kritiske spørsmål, synliggjøre ulike perspektiver og legge til rette for at barnehageansatte kan få erfaringer med å analysere egen rolle kritisk, fordrer at den enkelte barnehagelærer er trygg i rollen og trygg på at videoobservasjon og videobaserte samtaler hjelper en til å åpne opp for en praksis som er mangfoldig og av god kvalitet (Frønes, 2017; Moxnes, 2016; Nordahl \& Hansen, 2015).

Ved å løfte frem videoobservasjon og videobaserte samtaler som grunnleggende metoder for å få nye perspektiver på - og å kunne utfordre - egen praksis, kan vi bidra til at barn i spesialpedagogisk praksis blir møtt og fulgt opp på en god måte.

\section{Referanser}

Alvestad, M., Gjems, L., Myrvang, E., Storli, J. B., Tungland, I. B. E., Velde, K. L. \& Bjørnestad, E. (2019). Kvalitet i barnehagen. Rapport fra dybdestudien $i$ det longitudinelle forskningsprosjektet Gode barnehager for barn i Norge (GoBaN). (Rapport nr. 85). Universitetet i Stavanger. http://hdl.handle.net/11250/2630132

Aukrust, V. G. \& Rydland, V. (2009). Barnehagens kvalitet og skolefaglig læring: En kunnskapsoversikt. Norsk Pedagogisk Tidsskrift, 9o(3), 179-188.

Bjørnestad, E., Broekhuizen, M., Os, E. \& Baustad, A. G. (2018). Interaction quality in Norwegian ECEC for toddlers measured with the Caregiver Interaction Profile (CIP) scales. Scandinavian Journal of Educational Research, 64(6), 901-920. https://doi.org/10.1080/o0313831.2019.1639813

Bjørnestad, E. \& Os, E. (2018). Quality in Norwegian childcare for toddlers using ITERS-R. European Early Childhood Education Research Journal, 26(1), 111-127. https://doi.org/10.1080/1350293X.2018.1412051 
Brekke, M. B. R. \& Eide, M. L. (2019). Praksisfortelling, refleksjon og transformativ læring. Acta Didactica Norge, 13(3), 1-20. https://doi.org/10.5617/adno.6910

Cohen, L., Manion, L., Morrison, K. \& Bell, R. C. (2011). Research methods in education. Routledge.

Fossestøl, B. (2011). Evidens og praktisk kunnskap. Fontene forskning, 2(13), 55-66. https://fonteneforskning.no/pdf-15.19391.0.3.203c10f79e

Frønes, M. H. (2017). Observasjonens betydning i den profesjonelle praksis. Tidsskrift for nordisk barnehageforskning, 14(9), 1-13. https://doi.org/10.7577/ nbf. 1984

Gadamer, H.-G. (2003). Forståelsens filosofi (H. Jordheim, Overs.). Cappelen Damm Akademisk.

Grimen, H. (2008). Profesjon og kunnskap. I A. Molander \& L. I. Terum (Red.), Profesjonsstudier (s. 71- 85). Universitetsforlaget.

Hanssen, N. B. (2017). Preschool staff relationships with children with language difficulties: A comparative study in Belarusian and Norwegian preschools. European Journal of Special Needs Education, 33(3), 366-381. https://doi.org/ 10.1080/08856257.2017.1314112

Hanssen, N. B. (2018). Special educational needs in Norwegian and Belarusian preschools [Doktorgradsavhandling]. Nord universitet.

Hanssen, N. B. \& Hansén, S.-E. (2017). Special education needs activities for children with language difficulties: A comparative study in Belarusian and Norwegian preschools. Education Inquiry, 9(2),172-192. https://doi.org/10.1080/20004508. 2017.1380486

Kemmis, S. \& Smith, T. J. (2008). Personal praxis: Learning through experience. I S. Kemmis \& T. J. Smith (Red.), Enabling praxis: Challenges for education (2. utg., s. 15-36). Sense.

Klemp, T. (2013). Refleksjon - hva er det, og hvilken betydning har den i utdanning til profesjonell lærerpraksis? Uniped, 36(1), 42-58. https://doi.org/10.3402/uniped. v36i1.20957

Klette, T., Drugli, M. B. \& Aandahl, A. M. (2018). Together and alone a study of interactions between toddlers and childcare providers during mealtime in Norwegian childcare centres. Early Child Development and Care, 188(3), 387-398. https://doi.org/10.1080/03004430.2016.1220943

Knoblauch, H. (2008).Videografi. Å tolke samhandling i kontekst. Sosiologi i dag, 38(2), 7-24. http://ojs.novus.no/index.php/SID/article/view/942

Knoblauch, H., Schnettler, B., Raab, J. \& Soeffner, H. G. (2006). Video analysis: Methodology and methods. Peter Lang.

Kunnskapsdepartementet. (2017). Rammeplan for barnehagen: Innhold og oppgaver. https://www.udir.no/laring-og-trivsel/rammeplan-for-barnehagen/ 
Larsen, A. K. \& Slåtten, M. V.(2014). Nye tider - nye barnehageorganisasjoner. Fagbokforlaget.

Løkken, G. (2012). Levd observasjon. En vitenskapsteoretisk kommentar til observasjon som forskningsmetode. Cappelen Damm Akademisk.

Løkken, G. \& Søbstad, F. (2013). Observasjon og intervju i barnehagen. Universitetsforlaget.

Meløe, J. (1983). Om å se. http://www.jakobmeloe.com

Moxnes, A. R. (2016). Refleksjon i barnehagelærerutdanningen. Tidsskrift for Nordisk Barnehageforskning, 12(7), 1-13. https://doi.org/10.7577/nbf.1563

Nordahl, T., \& Hansen, O. (2015). Barnehagen: Betydningen av kvalitet i barnehagen. Gyldendahl Akademisk.

Nordahl, T., Persson, B., Brørup Dyssegaard, C., Wessel Hennestad, B., Vaage Wang, M., Martinsen, J. \& Johnsen, T. (2018). Inkluderende fellesskap for barn og unge. Ekspertgruppen or barn og unge med behov for sarskilt tilrettelegging. Fagbokforlaget.

Postholm, M. B. (2008). Teachers developing practice: Reflection as a key activity. Teaching and Teacher Education, 24(7), 1717-1728. https://doi.org/10.1016/ j.tate.2008.02.024

Schön, D. A. (1983). The reflective practitioner: How professionals think in action. Basic Books.

St.meld. 24 (2002-2003). Barnehagetilbud til alle - økonomi, mangfold og valgfrihet. Kunnskapsdepartementet. https://www.regjeringen.no/no/dokumenter/stmeldnr-24-2002-2003-/id13549o/

Statistisk sentralbyrå. (2020). Barnehager. https://www.ssb.no/utdanning/ statistikker/barnehager/aar-endelige

Utdanningsdirektoratet. (2017). Hva er kvalitetsutvikling i barnehagen?

Valle, A. M. (2018).Videoanalyse som metode i praksisforskning. I M. Krogtoft \& J. Sjøvoll (Red.), Masteroppgave i loererutdanninga. Cappelen Damm Akademisk.

Wackerhausen, S. (2008). Erfaringsrum, handlingsbåren kundskap og refleksjon. Refleksion i praksis. https://ruml.au.dk/fileadmin/www.ruml.au.dk/skriftserier/ refleksion_i_praksis/wackerhausen.pdf

Zeichner, K. \& Liu, Y. (2010). A critical analysis of reflection as a goal for teacher education. I N. Lyons (Red.), Handbook of reflective inquiry (s. 67-84). Springer.

Ødegård, E. (2011). Nyutdannede pedagogiske lederes mestring og appropriering av barnehagens kulturelle redskaper [Doktorgradsavhandling, Universitetet i Oslo]. USN Open Archive. http://hdl.handle.net/11250/2438207

Åmot, I. (2018). Barnehagens spesialpedagogiske virksomhet. Om bruk av grupper i en inkluderende praksis. I S. Østrem (Red.), Barnehagen som institusjon (s. 124-142). Cappelen Damm Akademisk. 



\title{
Klasseromsinteraksjon gjennom kameralinsen: En videobasert studie av lærers relasjons- og emosjonsarbeid i klasserommet
}

\section{Cathrine Arntzen Tollåli}

Nord universitet

Fredrik Rusk

Nord universitet

\section{Marie Nilsberth}

\section{Karlstads universitet}

\begin{abstract}
There is currently widespread agreement that creating positive studentteacher relations is important for learning and an educational goal in itself. The aim of this chapter is to investigate how teachers' relational and emotional work in the classroom is interactionally accomplished. Based on a conversation analytic and video-based study of plenary teaching, we show how teachers in the classroom balance control and progression in learning activities with relational considerations. In the analyzed examples we see how shifting between institutional and interpersonal frames of interaction are accomplished swiftly and in cooperation with the students. An interpersonal focus creates moments of emotional sharing that seems crucial in classroom interaction. By using video, we are able to describe facial expressions, bodily orientation and gaze and it is clear that teachers' relational and emotional work to a high degree is done non-verbally. The chapter demonstrates how video-based and descriptive studies of classroom interaction can shed light on relational and emotional aspects of teachers' professional practice and help teachers develop interactional competence that can result in more engaged and dynamic classrooms.
\end{abstract}

Keywords: teachers' relational and emotional work, video-based research, classroom interaction, conversation analysis

Sitering: Tollåli, C. A., Rusk, F. \& Nilsberth, M. (2021). Klasseromsinteraksjon gjennom kameralinsen: En videobasert studie av lærers relasjons- og emosjonsarbeid i klasserommet. I F. Rusk (Red.), Videoforskning på ulike leringsarenaer: Mangfoldig videodata i pedagogisk forskning og utvikling (Kap. 9, s. 183-203). Cappelen Damm Akademisk. https://doi.org/10.23865/noasp.153.ch9 


\section{Introduksjon}

De siste årene har vi sett en økt oppmerksomhet rundt viktigheten av positive lærer-elevrelasjoner og læreres relasjonskompetanse (Aspelin \& Jonsson, 2019; Tainio \& Laine, 2015). Målet med denne samtaleanalytiske og videobaserte studien er å skaffe kunnskap om hvordan lærere utøver relasjons- og emosjonsarbeid i klasserommet. Vi forstår her lærerens relasjonsarbeid som handlinger som bidrar til å bygge og opprettholde positive relasjoner med elevene. Emosjonsarbeid viser i denne sammenhengen til hvordan læreren håndterer emosjonelle aspekter $\mathrm{i}$ interaksjonen med elevene. Mer spesifikt handler det om hvordan læreren uttrykker egne emosjoner og holdninger og hvordan hun responderer på elevenes emosjonsuttrykk. Vi er interessert i hvordan læreren forholder seg til bestemte normer, forventinger og ansvar knyttet til å uttrykke emosjoner i klasserommet som en bestemt type institusjonell setting. For å bygge gode relasjoner er det ifølge Aspelin (2017) viktig med rom for at lærer og elever kan tre ut av de institusjonelt forankrede rollene som lærer og elev og samhandle med hverandre som unike personer i interpersonlige relasjoner. Hensikten med dette kapittelet er å undersøke hvordan læreren, i praksis, kan få til relasjons- og emosjonsarbeid i klasserommet. Vårt utgangspunkt i dette kapittelet er at relasjons- og emosjonsarbeid skjer i samspillet mellom lærer og elever, og at det dermed kan forstås og studeres som sosiale handlinger i klasseromsinteraksjon. Vi er spesielt opptatt av hvordan læreren balanserer relasjonelle og institusjonelle ansvar gjennom konkrete handlinger i interaksjonen med elevene. Kapittelet starter med en gjennomgang av et samtaleanalytisk perspektiv på sosial interaksjon og betydningen av å bruke lyd- eller videoopptak som datamateriale. Deretter introduserer vi en interaksjonell forståelse av relasjons- og emosjonsarbeid i institusjonelle kontekster og spesifikk kunnskap om hvordan dette arbeidet kan utøves av lærere i en klasseromskontekst. Med dette som utgangspunkt analyserer vi to eksempler fra datamaterialet med fokus på hvordan en slik analyse gjøres og hva slags kunnskap den kan gi om lærers relasjons- og emosjonsarbeid. 


\section{Samtaleanalyse og studiet av menneskelig samhandling}

Etnometodologien vokste ut av en interesse for de etno-metoder som gjør det mulig for mennesker å skape en felles forståelse av sine omgivelser og koordinere sine handlinger med andre (Heritage \& Stivers, 2012). Disse etno-metodene innbefatter blant annet måter å resonnere på, antakelser og tatt for gitt kunnskap som gjør det mulig for medlemmer av en kultur å handle på måter som er gjenkjennelig og meningsfull for andre. Samtaleanalyse er forankret i det samme, og studerer disse etnometodene gjennom å rette oppmerksomheten mot detaljene i menneskelig interaksjon, det store i det lille. Som samtaleanalytiker skal man hele tiden forankre sine observasjoner i data, og datamaterialet må bestå av lyd- eller videoopptak av sosial interaksjon. Vektleggingen og valg av empiri har hatt store konsekvenser for den type kunnskap samtaleanalytiske studier har utviklet. Gjennom gjentatte avspillinger av lydeller videoopptak kan man avdekke detaljer i interaksjonen som har vist seg å være av stor betydning når deltakerne koordinerer sine handlinger med hverandre. Den som snakker, kan for eksempel øke tempoet på bestemte steder for å unngå at noen andre tar ordet. Forlengede pauser kan indikere at mottakeren ikke har forstått, eller ikke kan eller vil komme med en foretrukket respons på det den andre nettopp har sagt.

Bruk av video har også gjort det mulig med detaljerte analyser av ansiktsuttrykk, blikk, gester og andre multimodale ressurser som er helt avgjørende når mennesker uttrykker og tolker hverandres emosjoner og holdninger (Goodwin et al., 2012). Videre er det å kunne gå frem og tilbake i et lyd- eller videoopptak en forutsetning for det som innen samtaleanalyse kalles for sekvensiell analyse, hvor de enkelte bidrag til samtalen forstås i lys av den handlingssekvens de inngår i. Gjennom å hele tiden være oppmerksom på hvordan handlinger i interaksjon blir behandlet av andre i neste taletur, passer man på at det er deltakernes tolkninger og ikke ens egne som ligger til grunn for analysen. Denne måten å analysere interaksjon på kalles next-turn proof procedure (Hutchby \& Wooffitt, 2008). Dette gjennomgripende fokuset på deltakernes egne forståelser av det som skjer er en av de viktigste grunnpilarene i samtaleanalyse, og det 
er med et slikt deltakerperspektiv vi i dette kapittelet studerer læreres relasjons- og emosjonsarbeid i klasserommet.

\section{Relasjons- og emosjonsarbeid i en institusjonell kontekst}

Vi går nå fra å se på hvordan lærers relasjons- og emosjonsarbeid kan studeres til hva det innebærer i praksis. En sentral del av relasjonsbygging er de emosjoner og holdninger man møter andre med. Gjennom intonasjon, gester, kroppslig orientering og holdning viser samtaledeltakere hvordan de forholder seg til dem de samhandler med (Goodwin et al., 2012). Handlinger som kan bidra til å fremme sosial solidaritet og bygge positive relasjoner til andre er blant annet å uttrykke at man er enig med noen, og å tilpasse seg eller speile andre sine handlinger (Lindström \& Sorjonen, 2012). På den annen side kan man skape avstand eller true sosiale relasjoner ved å overse det noen sier, å uttrykke uenighet med eller negative holdninger til andre (Goodwin et al., 2012; Lindström \& Sorjonen, 2012). I klasserommet må læreren håndtere slike emosjonelle og relasjonelle sider i interaksjonen samtidig som hun ivaretar andre oppgaver som å sørge for en viss kontroll og at elevene lærer det de skal (Waring, 2018). Dette kan gjøres gjennom å veksle mellom institusjonelle og interpersonlige rammer for interaksjonen (Tadic \& Box, 2019). Konseptualiseringen av slike rammer har sin opprinnelse i Goffmans' begrep framing (1974), og brukes her om felles forståelser for hvilke normer, roller og praksiser som er relevante å anvende når man inngår i ordnet og meningsfull interaksjon med andre i spesifikke situasjoner. Hva som utgjør rammer for interaksjonen her og nå bestemmes av og viser seg gjennom den tolkning av situasjonen som deltakerne viser for hverandre, taletur for taletur (Heritage \& Atkinson, 1984). Med utgangspunkt i forskning på klasseromsinteraksjon kan vi svært forenklet beskrive forskjellen mellom institusjonelle og interpersonlige rammer for interaksjonen på følgende måte: På den ene siden av et kontinuum har vi en streng etterlevelse av institusjonelt forankrede interaksjonsmønstre, med rekker av IRE-sekvenser, bestående av lærers initiativ (I), elevers respons (R) og lærers evaluering (E) av denne responsen (Mehan, 1979). Læreren kontrollerer hvem som får 
ordet, hva de skal snakke om og muligheter for elevdeltakelse (Gardner, 2019). Denne måten å ordne interaksjonen på er assosiert med tradisjonelle lærer-elevroller, karakterisert av lærers autoritet og emosjonell distanse (Richards, 2006). På den andre siden finner vi interaksjonsmønstre som likner på hverdagslige samtaler, hvor det er større rom for at elevene tar ordet og kommer med egne initiativer, og dermed at de kan påvirke hvordan samtalen utvikler seg (Gardner, 2019). Relasjonen mellom lærer og elever er i større grad preget av symmetri, og det er mer rom for interpersonlig interaksjon, uttrykk for personlige holdninger og emosjonell deling (Tadic \& Box, 2019; Waring, 2018).

Det kan synes kunstig å trekke et klart skille mellom institusjonell og interpersonlig interaksjon. Lærere håndterer interpersonlige hensyn hele tiden samtidig som de underviser, og personlige samtaler kan gi åpninger for læring (Tainio \& Laine, 2015; Waring, 2018). Det samtaleanalysen kan bidra spesifikt med er å gi oss nøkler til en forståelse av hvordan dette konkret oppnås i interaksjon. Multimodalt sammensatte uttrykk for emosjoner og holdninger er av stor betydning for hvordan relasjoner gjøres i klasseromsinteraksjon (Goodwin et al., 2012). Stadig bedre teknologi for å gjøre gode videoopptak har nå gjort det mulig å undersøke hvordan læreren bruker ulike multimodale ressurser for å ivareta institusjonelle og relasjonelle hensyn samtidig (Gardner, 2019). Et eksempel fra Hall et al.s (2019) studie av høytlesningsaktiviteter på barnetrinnet kan illustrere dette: Læreren stopper høytlesningen av en bok for å vise barna et bilde i boken. Idet læreren skal fortsette å lese tar en elev ordet og begynner å fortelle hva han tror kommer til å skje videre i fortellingen. Læreren ivaretar både progresjonen i aktiviteten og relasjonen til barnet ved å anerkjenne bidraget med et nikk og smil rettet mot barnet, samtidig som hun fortsetter å lese. Relasjons- og emosjonsarbeid viser seg også i hvordan lærer responderer når elever direkte utfordrer aktiviteten læreren legger opp til. Humor og/eller nedtonede smil kan være måter å håndtere elevers normative overtramp uten å måtte kjefte eller på andre måter true relasjonen til elevene (Jakonen \& Evnitskaya, 2020). Læreren kan også bruke smil for å håndtere emosjonelle problemer som kan oppstå når elever svarer feil på lærerens spørsmål (Tainio \& Laine, 2015). Å bygge positive relasjoner med elevene kan også gjøres gjennom å skape 
rom for, og stimulere til, interpersonlig fokus og emosjonell deling gjennom for eksempel å legge vekt på personlige følelser, erfaringer og fortellinger, samt humor, spøk og latter (Jakonen \& Evnitskaya, 2020; Waring, 2018). Studier av klasseromsinteraksjon har vist at mer personlige samtaler gjerne oppsto når læreren bydde på seg selv ved å uttrykke egne holdninger og identiteter (Richards, 2006), eller ved at læreren spurte elevene åpne eller personlige spørsmål og verbalt anerkjente og/eller bekreftet de emosjoner og holdninger som elevene ga uttrykk for (Waring, 2018).

Vi har nå beskrevet den kompleksiteten som kjennetegner klasseromsinteraksjon, der lærere og elever parallelt må håndtere institusjonelt forankrede oppgaver, samtidig som de skaper og opprettholder relasjoner og emosjonelle innslag. Det er derfor viktig at lærere utvikler kunnskaper om og innsikt i hvordan klasseromsinteraksjon er strukturert. Hvilke muligheter ligger i denne strukturen? Hvordan kan man som lærer dra nytte av ulike multimodale ressurser for å håndtere ulike hensyn og behov i denne konteksten? En bedre forståelse for hvordan interaksjon i klasserommet er strukturert kan fremme lærerens evne til å kunne utføre, vurdere og utvikle sin praksis. En slik profesjonell og kunnskapsbasert tilnærming til egen praksis er viktig for å kunne ta kvalifiserte beslutninger om hvordan man som lærer organiserer sin undervisning, fremmer gode relasjoner til elevene og varierer klasserommet på en måte som passer alle elever, både sosialt og faglig.

\section{Metode: Data og analyse}

Datamaterialet består av videoopptak av undervisning i Newton-rom. Dette er en læringsarena utenfor den ordinære skolen, hvor klasser fra skoler i området kan komme for læringsopplegg i moduler innenfor naturog realfag med oppdatert, avansert utstyr og spesialiserte Newton-lærere. Undervisningen i Newton-rommet er sentrert rundt problembasert og undersøkende læring, og er lagt opp som hele undervisningsdager hvor det veksles mellom plenumsundervisning og gruppearbeid. Vi har opptak fra to slike undervisningsdager, og denne artikkelen tar utgangspunkt i plenumsundervisning med to forskjellige 6.-klasser og to forskjellige Newton-lærere. I materialet er det ca. 3 timer og 20 minutter med opptak 
av plenumsundervisning som er spredt utover dagen. Lærerne kjenner i utgangspunktet ikke elevene fra før, men elevenes lærere fra hjemskolen er til stede gjennom hele dagen. Plenumsundervisningen foregår i et rom med en tribune hvor elevene sitter vendt mot læreren. De har ikke pulter og det er ikke muligheter for å ta notater underveis. Lærer bruker presentasjoner på en digital tavle, samt skriving på flippover og benytter en god del relevant utstyr i undervisningen; i dette tilfellet sykkelhjul, roboter og målebånd. De analyserte eksemplene viser noen fenomener som går igjen i materialet: lærer stiller oppriktige og personlige spørsmål innen elevers kunnskapsdomene, gjensidig latter, smiling, elever som uoppfordret tar ordet og uttrykker affektiv holdning. Studien er en deskriptiv studie, som tar sikte på å beskrive selve handlingene; hvordan relasjons- og emosjonsarbeid gjøres i plenumsundervisningen. Hensikten er dermed ikke å vurdere hvorvidt den ene eller andre måten å handle på fungerer bedre med tanke på å oppnå bestemte mål.

Transkriberingen er en viktig del av analyseprosessen, hvor detaljene i interaksjonen (intonasjon, pauser, turtaking, overlappende tale osv.) speiler et teoretisk fokus på relasjonen mellom bidrag til samtalen (Hutchby \& Wooffitt, 2008; Jefferson, 2004). Vi anser også timingen av ikke-verbale aspekter ved interaksjonen som viktig, og har derfor utarbeidet transkripsjoner hvor den sekvensielle plasseringen til verbale og ikke-verbale handlinger fremgår (Mondada, 2016). Vi bruker også en del bilder for å vise de multimodale helhetene hvor handlinger utføres på en annen måte enn det som er mulig med tekst. For å lette lesingen av analysen forklarer vi her betydningen bare av de symboler som er brukt i transkriptene. Vi henviser interesserte lesere til henholdsvis Jefferson (2004) og Mondada (2016) for en gjennomgang av de aktuelle transkripsjonssystemene i sin helhet.

Transkripsjon av tale hentet fra Jefferson (2004):

(.) minimal pause under 0,2 sekunder

(o.7) lengde på pause over 0,2 sekunder

$=\quad$ ingen pause mellom taleturer

[ begynnelse på overlappende tale

$>\quad$ raskere tale, $\varnothing \mathrm{kt}$ tempo 


$\begin{array}{ll}:: & \text { forlengelse av lyd, jo flere parenteser jo mer forlenget lyd } \\ ? & \text { svakt stigende intonasjon } \\ \downarrow & \text { tydelig fallende intonasjon } \\ \circ & \text { tale med mykere karakter eller lavere volum } \\ -: & \text { vokal med fallende intonasjonskontur } \\ - & \text { fremhevet tale, vektlegging av tale ved ekstra trykk }\end{array}$

Transkripsjon av multimodale aspekter ved interaksjonen hentet fra Mondada (2016):

$++\quad$ to identiske symboler viser plasseringen til og varighet av ikke-verbale handlinger i forhold til verbale ytringer.

$+----\rightarrow+$ handling fortsetter over flere linjer og til til neste + \# $\quad$ viser nøyaktig plassering av figurer/bilder

Videoopptakene var alltid underlagt streng etisk refleksjon av forskeren. Denne studien har fulgt generelle etiske retningslinjer som kreves for sosial videoforskning, og forskerne som er involvert i datainnsamlingen og analysen har tatt etiske hensyn i betraktning. Alle deltakende parter signerte samtykkeerklæringer. Deltakerne ble informert om formålet med opptakene, at deltakelse var frivillig og at de kunne trekke seg til enhver tid. Deres rett til personvern ble respektert gjennom hele forskningsprosessen. For mindreårige hjalp barnets foreldre (eller annen ansvarlig tredjepart, for eksempel en verge) barnet med å ta beslutningen om å delta eller ikke. Navnene på alle involverte er anonymisert, og deltakernes forventninger og rettigheter til personvern og fortrolighet ble tatt $\mathrm{i}$ betraktning gjennom hele datakonstruksjonen.

Det er etisk styrke i deltakerperspektivet som samtaleanalyse benytter. På grunn av, og takket være, et sterkt deltakerperspektiv som ideelt sett gjennomsyrer hele prosessen med samtaleanalytisk forskning - fra opptak til analyse og resultater - blir deltakerne sjelden beskrevet eller undersøkt gjennom kategorier eller definisjoner som blir gjort relevante av forskeren. Den data-interne analysen, next-turn proof procedure, siver ut kategorier, handlinger og aktiviteter som deltakerne selv gjør relevante i deres sosiale interaksjon. Med andre ord ligger den etiske styrken i det faktum at den samtaleanalytiske forskeren prøver å beskrive 
hva deltakerne gjør og hvordan de virker å forstå hva de gjør i spesifikke situasjoner, uten å bruke forhåndsbestemte kategorier. Det er en respekt overfor deltakernes handlinger og aktiviteter ved at analysen prøver, så nøyaktig som mulig, å beskrive situasjoner fra deltakerens perspektiv.

\section{Resultater}

\section{Eksempel 1: Humor, latter og fellesskap}

Vi skal nå se på en interaksjonssekvens som viser mange viktige sider ved lærers relasjons- og emosjonsarbeid. I eksempel 1 kan vi se hvordan interpersonlig fokus, humor og emosjonell deling kan oppstå i samspillet mellom lærer og elever og hvordan lærer hyppig og raskt veksler mellom institusjonelt og interpersonlig fokus. Eksempelet er hentet fra en introduksjonsforelesning i begynnelsen av en undervisningsdag. Læreren blir kjent med elevene, introduserer læringsmålene for dagen og går gjennom sentrale matematiske begreper. I denne aktuelle modulen, som heter «Roboter og matematikk», er det i hovedsak begrepene sirkel, omkrets, lengde og rotasjon som skal tematiseres. I løpet av dagen skal elevene løse praktiske oppgaver hvor de skal bruke og utvikle sin forståelse av disse begrepene. Eksempel 1 består av en interaksjonssekvens som oppstår ca. 10 minutter ut i forelesningen. Læreren har akkurat snakket med elevene om hvordan de skal jobbe sammen for å lære mest mulig, og at det å «snakke matte» er viktig for læring. Utdraget starter med at lærer spør elevene om de er en snakkeklasse eller stilleklasse. Vi vet at lærere stiller mange lukkede spørsmål i klasserommet, hvor læreren vet svaret og er ute etter en bestemt riktig respons (Walsh, 2011). Spørsmålet i linje 1 er til forskjell fra dette åpent, og læreren er ikke i utgangspunktet ute etter et bestemt korrekt svar. Spørsmålet går på elevenes erfaringer av seg selv som gruppe, og det er de som har forutsetninger for og rett til å vite noe om dette. Slike åpne spørsmål kan bidra til elevdeltakelse og åpne for et interpersonlig fokus (Walsh, 2011; Waring, 2016). Men hva slags funksjon spørsmålet har i denne bestemte settingen, kommer an på hvordan elevene oppfatter og responderer på dette. For å si noe om eller beskrive bestemte handlinger i interaksjonen benytter vi derfor next turn proof procedure, slik at det ikke er våre forhåndsoppfatninger som 
styrer analyseprosessen, men hvordan deltakerne viser hverandre sin forståelse.

\section{Transkript 1:}

Forkortelser: L: loerer O: Ole E: uidentifisert elev EE: flere elever PP: PowerPoint FO: Flippover

$1 \quad$ L: +KUlth (.) >e dåkker en snakkeklasse? eller en stille klasse $\downarrow<$ (.)

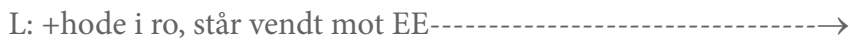

2 EE i kor: snak+ke[klasse $=$

EE: +smiler---------------- $\rightarrow$

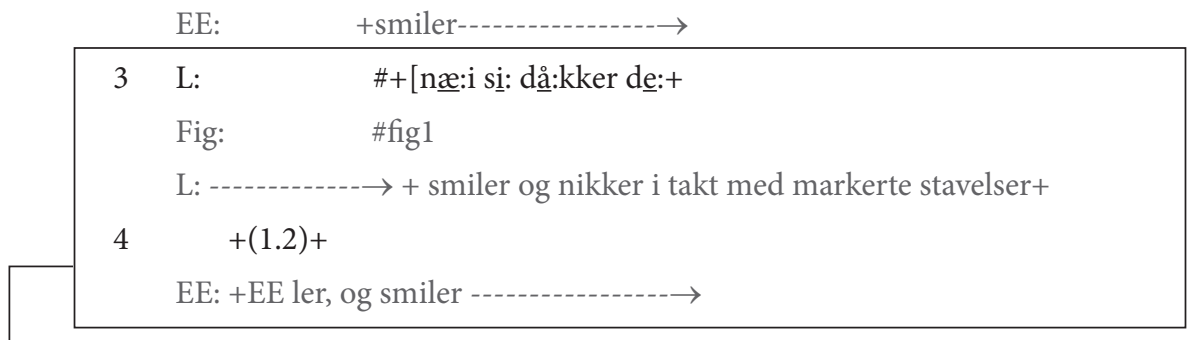

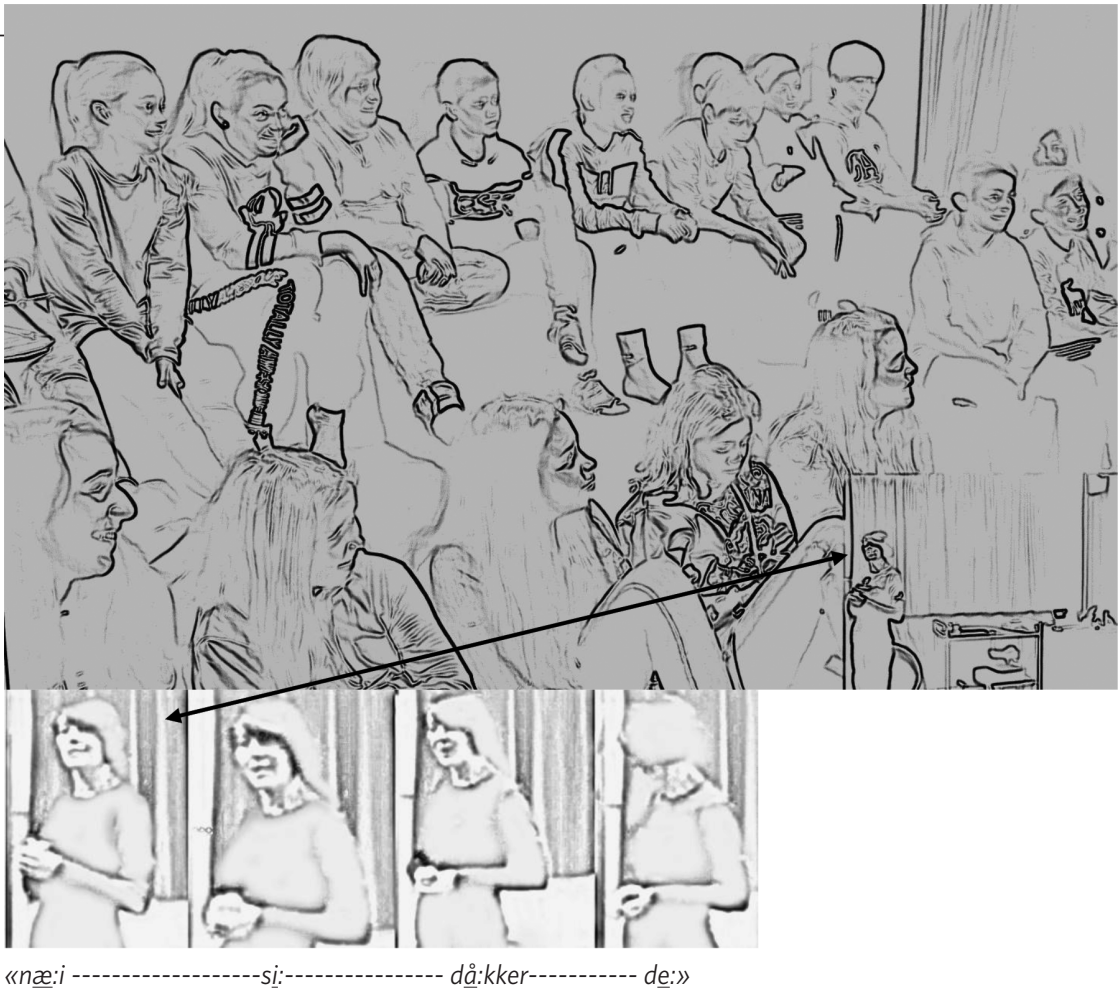

Figur 1. Gjensidig latter og smiling i det lærer responderer på en humoristisk måte i linje 3. Lærer legger vekt på hver enkelt stavelse med tonefall og bevegelse. 
5 L: +e e ikke åverraska + (.) da e då:kker væ̣:ldị: hel:dị: (1)

L: +smiler ----------+seriøst ansiktsuttrykk, nikk, samlet hender $\rightarrow$

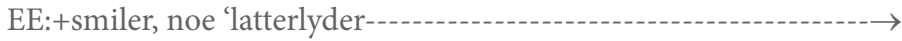

6 O: +he:Id $[\mathrm{i}:=+$

O: +smiler +

7 L: [+shønn dåkker koffer e si at dåkker e heldi? (.)+

L: ----- $\rightarrow$ +markert nikking, dreining overkropp ser på EE+

EE:

8 EE: næ:::: + +i [næi

9 L: $\quad$ [næi men da har dåkker jo ikke føllt me ${ }^{\circ}$ ka e sa hær $^{\circ}(0.7)$

L: $\quad$ +snur seg og går mot og peker på PP---------------------- $\rightarrow$

10 EE: \#å::ja:

Fig: \#fig2

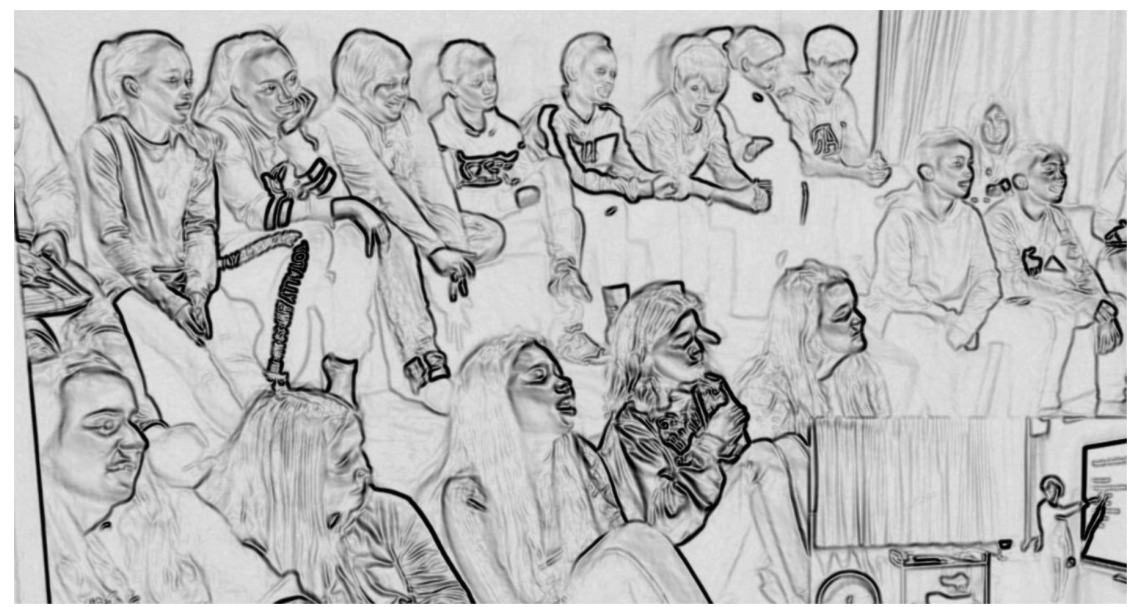

Figur 2. «Ka æ sa hær (0.7) \# åja»: 10 av 17 elever viser positiv holdning, smiler helt eller delvis, en del er noe vanskelig å se, men tenderer mot svakt smil. Nesten alle ser mot lærer.

Elevene responderer på spørsmålet i linje 1 umiddelbart, i kor og uten å vente på at læreren gir dem ordet. De fleste (14 av 17 elever) uttrykker en positiv og spøkefull holdning og ser på hverandre, samtidig som de svarer at de er en snakkeklasse, og viser at de behandler dette svaret som noe alle vet. Elevenes holdninger uttrykkes i stor grad gjennom ansiktuttrykk, kroppsspråk og blikk og det er bare noen få elever som responderer verbalt. Vi er derfor helt avhengige av videoopptak for å oppdage en viktig 
kvalitet ved elevenes respons her; nemlig at elevgruppen som helhet er samstemt i sin respons og viser en felles holdning til denne. Ved å ta utgangspunkt i elevenes respons ser vi at lærerens spørsmål (linje 1) initierer en interpersonlig fokusert utveksling, hvor elevene uttrykker sine emosjonelle holdninger. Læreren kan altså med et slikt spørsmål oppmuntre til eller åpne for emosjonell deling, men hun kan ikke fremtvinge en bestemt respons. Dette gjelder spesielt for slike åpne spørsmål, hvor det er elevene, og ikke læreren, som vet svaret. Videre er det denne humoristiske og samstemte responsen til elevene som legger grunnlaget for lærerens neste handling.

I linje 3 responderer læreren med å smile og gjøre en karikert bevegelse

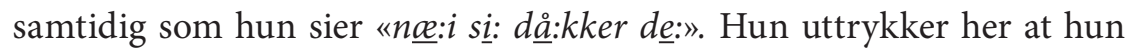
ikke er overrasket, men på en ironisk måte, og ved hjelp av et komplekst samspill mellom verbale og ikke-verbale handlinger. Elevene behandler lærerens taletur som humoristisk og viser dette gjennom å le høyt og smile, og de fortsetter å vise en positiv holdning ved å smile til læreren. Ved å bruke ironi på denne måten antar lærer delt forståelse med elevene, og tilslutter seg deres oppfatning av at de åpenbart er en snakkeklasse. Som vi var inne på tidligere, kan det å tilslutte seg eller uttrykke enighet med noens oppfatning på denne måten fremme sosial solidaritet og ivareta sosiale relasjoner (Lindström \& Sorjonen, 2012). I sekvensen ser vi hvordan samspillet mellom lærers åpne spørsmål, elevenes respons og lærers tilslutning til elevenes oppfatning gjør at det oppstår et øyeblikk av emosjonell deling og fellesskap. Slike øyeblikk kan ikke styres fullt ut av læreren, men er et resultat av et samarbeid mellom deltakerne. En viktig side ved lærers relasjons- og emosjonsarbeid er derfor å kunne åpne opp for og dra nytte av personlige, uforutsigbare og/eller spontane elevbidrag på en god måte.

I den videre samtalen ser vi hvordan læreren veksler fra de interpersonlige aspektene til å orientere seg mot en institusjonell ramme for interaksjonen ved å styre samtalen mot elevenes læring. I linje 5 sier

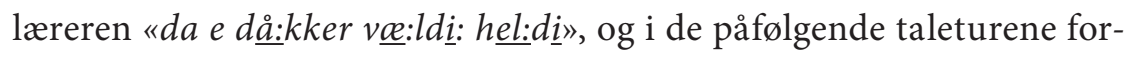
klarer hun at hun sier dette fordi man lærer mer ved å snakke matematikk. Etter en pause på 1 sekund tar en elev (Ola) uoppfordret ordet og sier «he:ldi?», med spørrende tonefall, samtidig som han smiler. Han 
orienterer seg her mot et uformelt turtakingssystem, hvor han kan ta ordet uten klarsignal fra lærer. Ved å smile ivaretar han relasjonelle aspekter samtidig som han utfordrer lærerens påstand. I overlapp med denne elevens taletur sier læreren: «shønn dåkker koffer e si at dåkker e heldi?», og viser at hun ikke tar som en selvfølge at elevene skjønner hva hun mener. Læreren og Ola etablerer her en delt forståelse av at lærerens påstand om at de er heldige trenger en nærmere forklaring. Elevgruppen tilslutter seg denne forståelsen ved å svare «nei» på lærerens spørsmål, og dermed kan hun fortsette med å forklare sitt poeng. Måten hun gjør dette på må forstås i lys av den emosjonelle holdning og intersubjektive forståelse som har oppstått mellom deltakerne i den forutgående sekvensen. Læreren anvender seg her av en delt innsikt i relasjonelle aspekter (at klassen er gode på å snakke) for å rette oppmerksomheten mot et institusjonelt sentralt aspekt; at det er viktig å snakke og uttrykke sine tanker når man skal lære matematikk. En viktig samtaleanalytisk innsikt er at en taleturs sekvensielle plassering er avgjørende for måten den er konstruert på, hva slags handling den utfører og hvordan den blir mottatt (Heritage \& Atkinson, 1984). Læreren begynner sin forklaring ved å peke på PowerPoint-presentasjonen mens hun sier «næi men da har dåkker jo ikke føllt me ${ }^{\circ} k a$ e sa hor ${ }^{\circ}$ » (linje 9). Denne taleturen er rent verbalt konstruert som en anklage eller kritikk. Men for å tolke ytringens mening i akkurat denne situasjonen, må forskeren, på samme måte som elevene, gå ut ifra den kontekst som de forutgående taleturene og humoristiske holdningen utgjør. Ved avslutning av lærerens taletur ser alle synlige elever oppmerksomt på lærer. Åtte elever smiler, og elevgruppen som helhet orienterer seg ikke til det lærer sa som kritikk eller noe negativt. Hvorvidt en ytring oppfattes som kritikk eller vennlig erting, handler blant annet om deltakernes emosjonelle status i forhold til hverandre. En viss emosjonell nærhet mellom deltakerne sannsynliggjør en tolkning av slike tvetydige ytringer som vennlig erting, og ikke kritikk (Stevanovic \& Peräkylä, 2014). Ved å spøke på denne måten legger lærer til grunn en viss emosjonell nærhet til eller fellesskap med elevene, som også legger grunnlaget for utvikling av undervisningsinnhold. Vi ser også at elevene deler denne forståelsen av lærer-elevrelasjonen på det aktuelle tidspunktet. Men 
læreren løper også en risiko for at elevene oppfatter hennes ytring som kritikk. Det er derfor viktig at læreren både er oppmerksom på elevenes emosjonelle uttrykk og har innsikt i hvordan egne handlinger kan bidra positivt eller negativt til relasjonen med elevene i ulike situasjoner. Forskning på klasseromsinteraksjon kan bidra med ny kunnskap og økt bevissthet om egen praksis når det kommer til disse sidene ved lærers relasjonskompetanse.

\section{Eksempel 2: Uttrykk for og anerkjennelse av elevenes emosjonelle holdning}

Vi skal nå se på et annet eksempel hvor læreren spør etter og responderer på elevenes uttrykk for emosjonell holdning til matematikk. Eksempel 2 er i likhet med eksempel 1 hentet fra introduksjonsforelesningen til en undervisningsdag om «Roboter og matematikk», men her med en annen lærer og en annen klasse. Vi skal se på en interaksjonssekvens som skjer ca. 6 minutter ut i forelesningen. Vi kommer inn i samtalen idet læreren avslutter en gjennomgang av hvordan de skal jobbe for å lære mest mulig i løpet av dagen og spør elevene hva de synes om at de skal ha mye om matematikk. Eksempelet viser hvordan læreren håndterer elevers uttrykk for en negativ holdning til faget, og hvordan hun må balansere mellom emosjonell nærhet og profesjonell distanse når hun uttrykker sin emosjonelle holdning til elevenes uttrykte holdning.

\section{Transkript 2}

Forkortelser: L: lærer K: Kim E: uidentifisert elev EE: flere elever PP: PowerPoint FO: Flippover

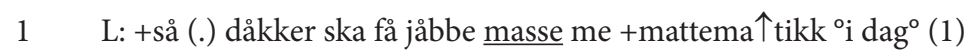

$\mathrm{L}+$ snur seg bort fra elever mot FO ---- + ansikt mot elever--- $\rightarrow$

2 L: ${ }^{\circ}$ ka dåkker syns om de ${ }^{\circ} ?+(1)$ \#

Fig: $\quad$ \#fig3

$+($ Pause 1.1 sek $)+$

$\mathrm{L}:+$ tar frem nytt ark FO + smiler----- $\rightarrow$

$\mathrm{K}$ : + rekker opp hånden 


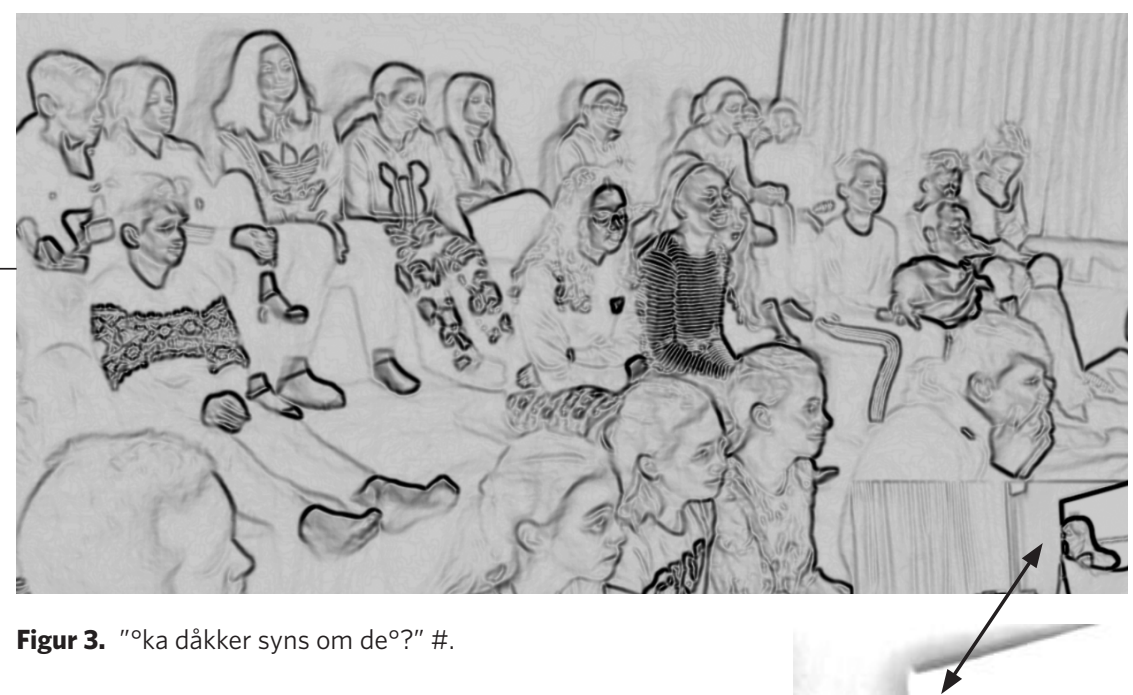

$3 \quad$ K: helt ok=

4 EE: (h)e(h)e

$+($ pause 1 sek $)+$

L: +peker på og smiler til Kim+

$5 \quad \mathrm{~K}:$ +viss+ de helt vanli matematikk så vil æe elsk de+(0.8)

$\mathrm{K}$ : +hånd ned+

EE: +flere ser på K når han prater+

L: $\quad$ holder ark i ro, smiler med åpen munn til Kim----- $\rightarrow$

$6 \quad$ L: åh du e gla i matmatikk?+ (.)

L: smiler ---------------- $\rightarrow+$

$7 \quad \mathrm{~K}:+$ næ:i $(1)+$

EE:+noen hvisker, noen ler+

8 L: +ㅁ: du: ikkje? ${ }^{\circ}$ gla i matmatikk ${ }^{\circ}$ (.) e de fleire såm e eni me han+

L: +lukker munn, hake frem, ser på FO, seriøst/nøytralt ansiktsuttrykk+

$$
+(\text { pause } 1 \text { sek })+
$$

EE: +4 elever rekker opp hånden, de ser rundt på hverandre+

9 L: +kor mange e:lska matmatikk hæ:r+

L: + ark skiftet går fra FO mot EE og smiler+

+ (pause 2 sek)+

EE: +6 elever rekker opp hånden+ 

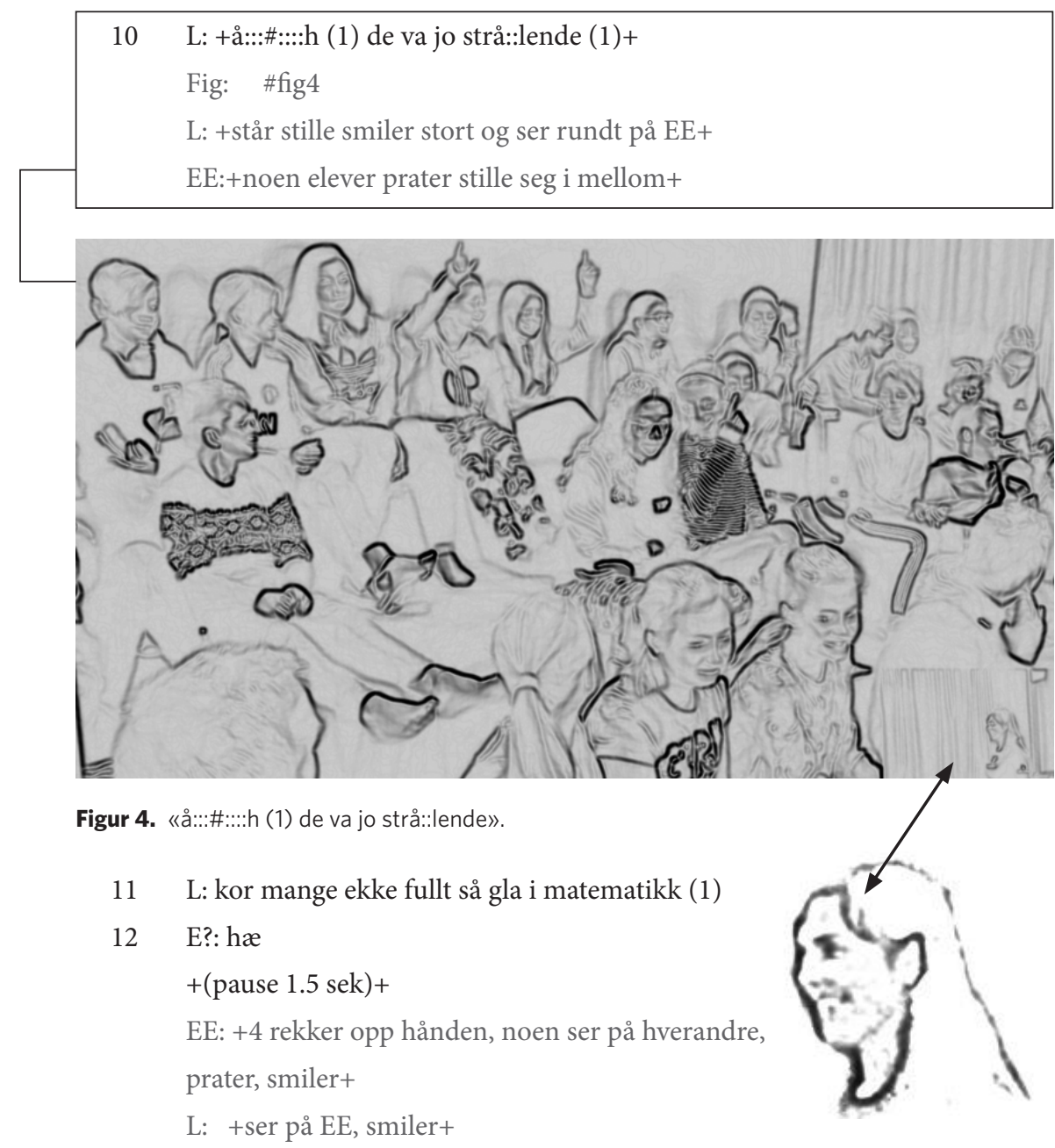

13 L: åsså e de mange såm e sånn mett på treet hær (0.5)

Sekvensen starter med at læreren spør elevene hva de synes om at de skal ha mye matematikk i dag. Spørsmålet i linje 2 er åpent formulert ( ${ }^{\circ} k a$ dåkker syns om de ${ }^{\circ}$ ?») og legger lite føringer på elevenes responser. Læreren spør her elevene om deres personlige holdninger til matte, og på samme måte som i eksempel 1 har elevenes oppfatning av og respons på spørsmålet stor betydning for de interaksjonelle muligheter som åpner seg i samtalen som følger. Etter at læreren har fullført sitt spørsmål er det 2-3 elever som smiler. En annen elev uttrykker en negativ emosjonell holdning ved å vrenge munnen nedover og skyte frem underleppen. 
Deretter er det gradvis flere elever som smiler. Noen fremviser ingen synlig respons, og forholder seg ikke til situasjonen som noe de trenger å svare på. Elevene viser altså ulike tolkninger av situasjonen, og responsen gjøres utelukkende ikke-verbalt til å begynne med. Til forskjell fra elevenes samstemte respons i eksempel 1, kommer elevene her med flere ulike responser på samme tid, og læreren må forholde seg til denne variasjonen i sin respons.

Etter en pause på ca. 2 sekunder, hvor læreren skifter ark på flippoveren, er det en elev (vi kaller ham Kim) som rekker opp hånden. Læreren gir ham ordet, og han svarer «viss de helt vanli matematikk så vil oe elsk de». Denne første verbale elevresponsen fører til en reparasjonssekvens, hvor læreren forsøker å få tak på hva Kim mener. Det kommer frem at han ikke er glad i matematikk, og at minst fire andre elever er enige med ham (linje 6-8). Å spørre elevene om deres personlige følelser og holdninger er å åpne for det uforutsigbare. Som vi ser er det ikke gitt at elevene viser en positiv holdning til hverken læreren, faget eller det de holder på med. Hvordan læreren responderer på elevenes uttrykte negative holdning har ikke bare betydning for den enkelte eleven som læreren henvender seg direkte til; det kan også ha betydning for hvordan den videre samtalen påvirker den generelle emosjonelle holdningen i klassen, og dermed forutsetningene for den felles læringsaktivitet som planlegges.

Læreren responderer ved å utvide sekvensen. Fra linje 8-13 ser vi flere påfølgende IRE- sekvenser hvor lærer spør elevene om hvem som har ulike innstillinger til matematikk. I linje 9 spør hun hvor mange som elsker matematikk, hvorpå 6 elever rekker opp hånden høyt og smiler. Læreren responderer ved å verbalt og ikke-verbalt uttrykke sin positive holdning til dette. Hun står stille og smiler stort i det hun sier «å::::::::h (1) de va jo strå::lende». Deretter spør læreren hvor mange som ikke er fullt så glade i matematikk. Nå er det 3 elever som ser på hverandre, rekker opp hånden og smiler. Læreren står i ro, ser på elevene og smiler og viser her sin emosjonelle holdning til elevenes emosjonelle holdning. Hun tilslutter seg ikke elevenes holdning, da dette innebærer at lærer sier seg enig med elevene, ved for eksempel å uttrykke at hun selv elsker matematikk. Og selv om dette på sett og vis kan forventes, så er det ikke det hun gjør i sin taletur. Ved dette kan hun sies å opprettholde en viss emosjonell 
distanse ved å ikke tilslutte seg en bestemt elevgruppe (de som liker matematikk), noe som vil kunne ekskludere andre. Dette viser kompleksiteten i lærerens relasjons- og emosjonsarbeid, hvor en skal tilstrebe å skape relasjon og/eller emosjonell nærhet, men samtidig ta ansvar for at ingen elever føler seg ekskluderte. I eksempel 1 fremstår elevgruppen som samlet, og å tilslutte seg denne ekskluderer i utgangspunktet ingen. I linje 13 oppsummerer læreren sekvensen med «åsså e de mange såm e sånn mett på treet hæer», før hun går over til å introdusere det matematiske innholdet. Gjennom denne utvidede sekvensen sørger læreren for at den umiddelbare konteksten for introduksjonen er at det er ulike holdninger til matematikk i denne klassen, og at dette er helt greit. Nærmere studier av hvordan lærer håndterer ulike og motstridende elevstemmer og elevenes verbale og ikke-verbale responser på trengs for å få en bedre forståelse for denne siden ved lærers relasjonskompetanse.

\section{Diskusjon}

Vi har undersøkt lærers relasjons- og emosjonsarbeid på bakgrunn av en videobasert studie av klasseromsinteraksjon og en samtaleanalytisk tilnærming med en oppmerksomhet mot detaljer, multimodalitet og det store i det lille. Hva kan så denne tilnærmingen gi oss? Hva kan vi si om hvordan lærers relasjons- og emosjonsarbeid gjøres? Og hva kan læreren ta med seg videre? Eksemplene i kapittelet viser hvordan det å kunne skifte mellom institusjonelle og interpersonlige rammer for interaksjonen er en viktig del av lærers relasjons- og emosjonsarbeid i klasserommet. Gjennom inngående samtaleanalyser har vi vist i detalj hvordan slike skift gjøres i møtet mellom lærer og elever. Å bruke video i forskningen gir oss muligheten til å se nærmere på de ansiktsuttrykk, kroppslige orienteringer og blikk som deltakerne anvender seg av i tillegg til verbal tale. Det kommer tydelig frem at mye av det vi omtaler som relasjonsog emosjonsarbeid gjøres ikke-verbalt, for eksempel gjennom øyeblikk med delt oppmerksomhet på en spesifikk ytring eller gjensidig smil og latter. Dette er øyeblikk av emosjonell deling som ut ifra et relasjonelt perspektiv fremstår som avgjørende i klasseromsinteraksjonen. Vi har vist eksempler på hvordan en lærer kan anvende seg av slike øyeblikk for 
å, til tross for at hun ikke kjenner klassen fra før, skape en felles holdning til de oppgaver hun skal introdusere.

Den ikke-verbale emosjonelle holdningen som en gruppe uttrykker fungerer som et bakteppe for å tolke det som blir sagt. Vi har sett hvordan spørsmål som læreren i utgangspunktet ikke vet svaret på og spørsmål om elevenes emosjonelle holdning til noe, kan skape åpninger for interpersonlig fokusert interaksjon. Men dette skjer alltid som et samarbeid, og elevenes responser er ikke alltid som ønsket eller forventet. $\AA$ bevege seg inn på det personlige og utøve relasjons- og emosjonsarbeid innebærer derfor en viss risiko eller uforutsigbarhet, som man ikke kommer utenom. Aspelin (2001) er inne på dette når han skriver at sosiale fellesskap som oppstår i mellommenneskelige møter ikke er et resultat av den enkeltes intensjoner, men noe som oppstår som følge av flere personers gjensidige relaterte handlinger. Lærerens oppgave er dermed ikke å skape og bygge relasjoner, men å være nærværende i relasjoner og søke samklang i samspillet (Aspelin, 2001). Gjennom vår analyse ser vi hva dette innebærer av konkrete handlinger i interaksjon; en stadig gjensidig avhengighet mellom bidrag.

Interpersonlig fokus kan være en tilsynelatende betydningsløs spøkefull sekvens midt i lærerens gjennomgang av fagstoff. Men likevel gjør det noe med deltakernes uttrykte holdning, både verbalt og ikke-verbalt, til mer fokuserte læringsaktiviteter. Den videobaserte analysen viser tydelig hvordan deltakernes engasjement og felles emosjonelle holdning forandres i disse øyeblikkene. Gjennom å analysere interaksjonen taletur for taletur har vi sett at institusjonelle og interpersonlige rammer for interaksjonen ikke er adskilte aktiviteter. De er heller raske skift i fokus mellom ulike potensielle rammer for interaksjonen som er til stede samtidig. Basert på vår analyse mener vi at nettopp skiftene mellom det interpersonlige og det institusjonelle bør forstås som viktige ressurser for å åpne opp for elevers aktive deltakelse, selv under tilsynelatende helt lærerkontrollerte IRE-sekvenser.

Til sist: Relasjons- og emosjonsarbeid trenger ikke å være så komplisert. Det kan være små øyeblikk, hvor et nikk og smil, en spøk eller deling av en personlig erfaring kan bety mye for utviklingen av samtalen og for deltakernes emosjonelle holdning. Å utøve relasjons- og emosjonsarbeid 
i institusjonelle settinger innebærer å balansere ulike hensyn. Det kan være å bevege seg over i det interpersonlige ved å dra inn inn elevenes personlige erfaringer, følelser og subjektivitet i samtalen. Da må læreren balansere sin anerkjennelse av og/eller enighet med elevene, med en viss institusjonell distanse. Dette bunner i at læreren har et ansvar for å inkludere alle elever, sørge for at ingen føler seg avvist eller oversett, samt fremme progresjon i læringsaktiviteter og arbeidsro i klassen.

\section{Referanser}

Aspelin, J. (2001). Relationer i undervisningen. Utbildning \& Demokrati - Tidskrift För Didaktik Och Utbildningspolitk, 10(3), 27-33. https://doi.org/10.48059/uod. v10i3.708

Aspelin, J. (2017). We can recite it in chorus now! An interactionist approach to the teacher-student relationship and teachers' relational competence. Classroom Discourse, 8(1), 55-70. https://doi.org/10.1080/19463014.2016.1271991

Aspelin, J. \& Jonsson, A. (2019). Relational competence in teacher education. Concept analysis and report from a pilot study. Teacher Development, 23(2), 264-283. https://doi.org/10.1080/13664530.2019.1570323

Gardner, R. (2019). Classroom interaction research: The state of the art. Research on Language and Social Interaction, 52(3), 212-226. https://doi.org/10.1080/08351813. 2019.1631037

Goffman, E. (1974). Frame analysis. Harper \& Row.

Goodwin, M., Cekaite, A. \& Goodwin, C. (2012). Emotion as stance. I A. Peräkylä \& M. L. Sorjonen (Red.), Emotion in interaction (s. 16-41). Oxford University Press.

Hall, J. K., Malabarba, T. \& Kimura, D. (2019). What's symmetrical? A teacher's cooperative management of learner turns in a read-aloud activity. I J. K. Hall \& S. D. Looney (Red.), The embodied work of teaching (1. utg., s. 81-112). Multilingual Matters.

Heritage, J. \& Atkinson, M. J. (1984). Structures of social action: Studies in conversation analysis. Camebridge University Press.

Heritage, J. \& Stivers, T. (2012). Conversation analysis and sociology. I J. Sidnell \& T. Stivers (Red.), The handbook of conversation analysis (s. 657-673). John Wiley and Sons. https://doi.org/10.1002/9781118325001.ch32

Hutchby, I. \& Wooffitt, R. (2008). Conversation analysis. Polity Press.

Jakonen, T. \& Evnitskaya, N. (2020). Teacher smiles as an interactional and pedagogical resource in the classroom. Journal of Pragmatics, 163, 18-31. https:// doi.org/10.1016/j.pragma.2020.04.005 
Jefferson, G. (2004). Glossary of transcript symbols with an introduction.

I G. H. Lerner (Red.), Conversation analysis: Studies from the first generation (s. 13-31). https://doi.org/10.1075/pbns.125.02jef

Lindström, A. \& Sorjonen, M. L. (2012). Affiliation in conversation. I J. Sidnell \& T. Stivers (Red.), The handbook of conversation analysis (s. 350-369). John Wiley and Sons.

Mehan, H. (1979). Learning lessons: Social organization in the classroom. Harvard University Press.

Mondada, L. (2016, juli). Conventions for multimodal transcription. https:// franzoesistik.philhist.unibas.ch/fileadmin/user_upload/franzoesistik/mondada_ multimodal_conventions.pdf

Richards, K. (2006). "Being the teacher": Identity and classroom conversation. Applied Linguistics, 27(1), 51-77. https://doi.org/10.1093/applin/amio41

Stevanovic, M. \& Peräkylä, A. (2014). Three orders in the organization of human action: On the interface between knowledge, power, and emotion in interaction and social relations. Language in Society, 43(2), 185-207. https://doi.org/10.1017/ So047404514000037

Tadic, N. \& Box, C. D. (2019). Attending to the interpersonal and institutional contingencies of interaction in an elementary classroom. I J. K. Hall \& S. D. Looney (Red.), The embodied work of teaching (1. utg., s. 43-80). Multilingual Matters.

Tainio, L. \& Laine, A. (2015). Emotion work and affective stance in the mathematics classroom: The case of IRE sequences in Finnish classroom interaction.

Educational Studies in Mathematics, 89(1), 67-87. https://doi.org/10.1007/s10649015-9591-5

Walsh, S. (2011). Exploring classroom discourse: Language in action. Routledge.

Waring, H. Z. (2016). Theorizing pedagogical interaction. Routledge.

Waring, H. Z. (2018). Managing control and connection in an adult ESL classroom. Research in the Teaching of English, 49(1), 52-74. 



\section{Om forfatterne}

Ingvill Berg er pedagogisk leder i Newton-administrasjonen hos FIRST Scandinavia. Master itilpasset opplæring, generell didaktikk. I masterstudiet analyserte hun videofilmer fra undervisning i såkalte Newton-rom og studerte hvordan kunnskapsposisjonering og kunnskapsforhandling foregår i elevers samhandling når de arbeider i grupper.

Natallia Bahdanovich Hanssen er førsteamanuensis i spesialpedagogikk ved Fakultet for lærerutdanning og kunst- og kulturfag ved Nord universitet. Hennes forskningsområder omfatter først og fremst spesialpedagogikk og spesialpedagogiisk praksis - samt ulike problemstillinger knyttet til prinsippet om inkludering og spesialpedagogens profesjon.

Marit Krogtoft er førsteamanuensis og har vært tilsatt på lærerutdanninga i Bodø siden 1998, og har skrevet doktoravhandling om praktiske arbeidsformer i norskfaget på ungdomstrinnet. Forskningsinteressen sprer seg fra språk og dialekter i Bodø (nytt forskningsprosjekt i år) via læring i sin alminnelighet til læring ved bruk av musikk.

Julie Lysberg er ansatt ved barnehage- og skolekontoret i Bodø kommune og er stipendiat i offentlig sektor. Hun tar en ph.d. i studier av profesjonspraksis ved Nord universitet. Prosjektet undersøker hva som kjennetegner læreres samarbeid i team og hvordan læreres profesjonelle læring konstitueres.

Marie Nilsberth er dosent i pedagogisk arbeid ved Karlstads universitet. Hennes forskningsinteresse berører spørsmål om læreres og elevers sosiale samspill, hvor hun for tiden driver flere forskningsprosjekter om hva digitaliseringsprosesser betyr for elever og undervisningen i klasserommets interaksjon. 
Sandra Nystø Ráhka er stipendiat ved Fakultet for lærerutdanning og kunst- og kulturfag ved Nord universitet. Hun forsker på de nye læreplanene i faget samisk som andrespråk og hvordan begrepet sterke pråkopplæringsmodeller blir tolket og iverksatt i skolen.

Fredrik Rusk er førsteamanuensis II i pedagogikk ved Fakultet for lærerutdanning, kunst- og kulturfag ved Nord universitet, og docent i pedagogik med inriktning mot digital interaktion ved Fakulteten för pedagogik och välfärdsstudier ved Åbo Akademi. I sin forskning bruker han samtaleanalyse og interaksjonsanalyse med videoopptak for å studere læring i interaksjon, flerspråklighet og sosial identitet i og utenfor skolen samt læring i og gjennom digital interaksjon, som smarttelefoner, videokonferanser og videospill.

Wenche Rønning er førsteamanuensis i pedagogikk ved Fakultet for lærerutdanning, kunst- og kulturfag ved Nord universitet. Klasseromsforskning, forskning om læreres tenkning og profesjonelle utvikling, og stedsbasert læring er hennes primære forskningsinteresser.

Matilda Ståhl doktor i pedagogik vid Åbo Akademi, Finland. Hennes forskning fokuserar på identitetskonstruktion online genom forskning ur ett deltagarpespektiv på spel och sociala medier och det aktuella bokkapitlet utgör en fortsättning på den metodologiska diskussion hon startat i doktorsavhandlingen.

Trine Telnes er universitetslektor i pedagogikk, og stipendiat i profesjonsvitenskap ved Nord universitets barnehagelærerutdanning, Fakultet for lærerutdanning og kunst- og kulturfag. Hun er utdannet barnehagelærer med master innenfor kunstfagsdidaktikk og barnehagepedagogikk. Som forsker er hun aktiv i forskningsgruppen Læring i interaksjon, og hun er spesielt interessert i profesjonsforskning, praksisforskning, kunstbasert forskning og videoforskning.

Cathrine Arntzen Tollåli er stipendiat ved Fakultet for lærerutdanning, kunst og kultur ved Nord Universitet. Hun skriver for tiden doktorgrad 
om lærers relasjonskompetanse, med fokus på hvordan lærere håndterer relasjonelle og emosjonelle hensyn i interaksjon med elever. Bruk av video og ulike metoder for å studere klasseromsinteraksjon er sentrale temaer i hennes forskning.

May Line Rotvik Tverbakk er førsteamanuensis i norskdidaktikk ved Nord universitet. Forskningsinteresser: video som verktøy i forsking, lese- og skriveundervisning, lese- og skrivevansker, læreres profesjonelle utvikling. 
